\title{
Lewis-Acid-Promoted Ligand-Controlled Regiodivergent Cycloaddition of Pd-Oxyallyl with 1,3-Dienes: Reaction Development and Origins of Selectivities
}

\author{
Weiwei Chai, ${ }^{a}$ Qingyang Zhou, ${ }^{\mathrm{b}}$ Wenna Ai, ${ }^{\mathrm{b}}$ Yin Zheng, ${ }^{\mathrm{a}}$ Tianzhu Qin, ${ }^{\mathrm{a}}$ Xiufang $\mathrm{Xu} \mathrm{u}^{\star \mathrm{b}}$ \\ and Weiwei $\mathrm{Zi}^{*, \mathrm{a}}$ \\ a State Key Laboratory and Institute of Elemento-Organic Chemistry, College of \\ Chemistry, Nankai University, Tianjin 300071, China. \\ ${ }^{b}$ Key Laboratory of Advanced Energy Materials Chemistry (Ministry of Education), College of \\ Chemistry, Nankai University, Tianjin 300071, China.
}

\section{Table of Contents}

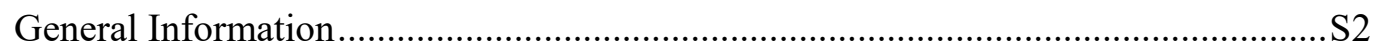

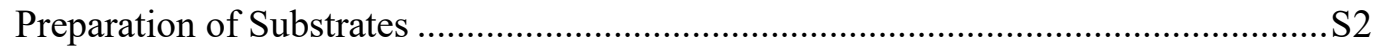

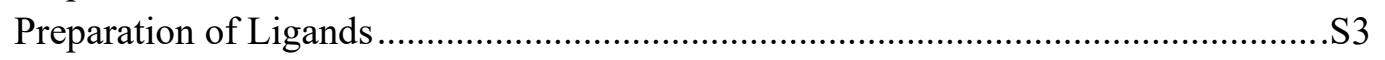

General Procedure for (3+2) Cycloaddition ……................................................ 4

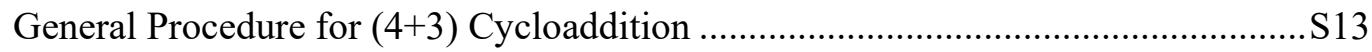

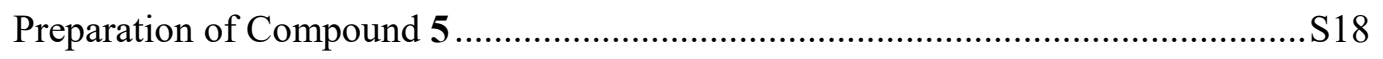

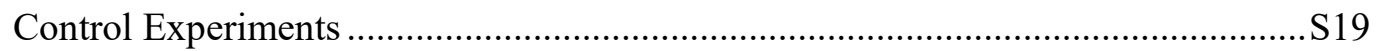

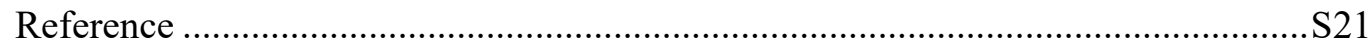

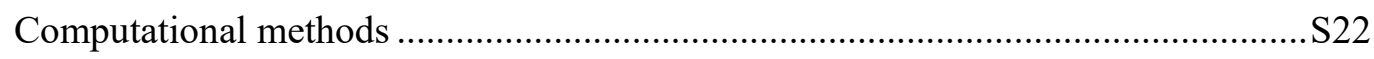

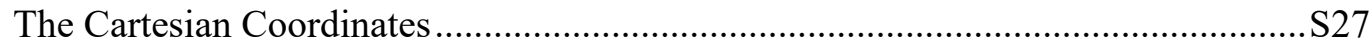

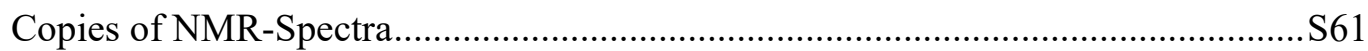




\section{General Information}

Unless otherwise noted, all reactions were assembled on a Schlenk vacuum line or in a glovebox using oven-dried glassware and were stirred with Teflon-coated magnetic stirring bars. Commercially available ligands were purchased from Strem Chemicals or Sinocompound Catalysts Co., Ltd. and were used as received. Unless otherwise noted, reagents were obtained from commercial sources and used without further purification. THF, $\mathrm{Et}_{2} \mathrm{O}$, toluene were distilled with $\mathrm{Na}$ before using. Dichloromethane was distilled with $\mathrm{CaH}_{2}$ before using. All other dried solvents (DMF, $\mathrm{CH}_{3} \mathrm{CN}, \mathrm{PhH}, 1$,4-dioxane, $\mathrm{Et}_{3} \mathrm{~N}$, DIPEA) were purchased from MERYER (Shanghai) Chemical Technology Co., Ltd. TLC analysis of reaction mixtures was performed on huanghai silica gel 60 F254 TLC plates and visualized by UV, $\mathrm{I}_{2}$ /silica, and/or ceric ammonium molybdate stain. All work-up and purification procedures were carried out with reagent grade solvents in air. Reaction temperatures above $23{ }^{\circ} \mathrm{C}$ refer to temperatures of an aluminum heating block or a silicon oil bath, which were controlled by an electronic temperature modulator from IKA. Flash chromatography was carried out with silica gel $200-300$ or $300-400$ mesh. ${ }^{1} \mathrm{H}$ and ${ }^{13} \mathrm{C}$ NMR spectra were recorded with Bruker AV-400 spectrometers and were referenced to residual ${ }^{1} \mathrm{H}$ and ${ }^{13} \mathrm{C}$ signals of the deuterated solvents respectively $(\delta \mathrm{H} \mathrm{7.26, \delta} \mathrm{C} 77.00$ for chloroform). Abbreviations are as follows: $\mathrm{s}$ (singlet), $\mathrm{d}$ (doublet), $\mathrm{t}$ (triplet), $\mathrm{q}$ (quartet), $\mathrm{m}$ (multiplet), br (broad). HRMS was performed on a Varian QFT-ESI instrumental.

\section{Preparation of Substrates}

All 1,3-dienes used in this work were known compounds and were prepared according to literature procedure $^{1,2}$. The MECs were prepared using a reported method ${ }^{3}$ as follows:
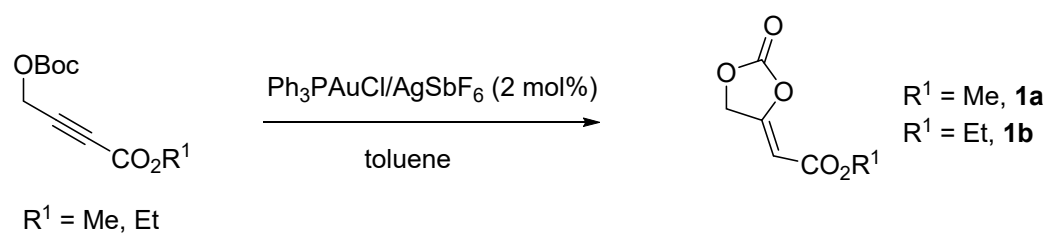

In a three-necked flask, $\mathrm{Ph}_{3} \mathrm{PAuCl}(49 \mathrm{mg}, 0.1 \mathrm{mmol})$ and $\mathrm{AgSbF}_{6}(33 \mathrm{mg}, 0.1 \mathrm{mmol})$ were dissolved in toluene and stirred at room temperature for 15 minutes. Then the propargylic alcohol carbonate $(5 \mathrm{mmol})$ was added slowly to the above solution and the reaction mixtures was stirred for another 15 minutes. Then the reaction suspension was filtered to give crude $\mathbf{1 a}$ or $\mathbf{1} \mathbf{b}$, which was purified by recrystallization from $\mathrm{CH}_{2} \mathrm{Cl}_{2} / \mathrm{Et}_{2} \mathrm{O}$.

\section{Methyl (Z)-2-(2-oxo-1,3-dioxolan-4-ylidene)acetate (1a)}

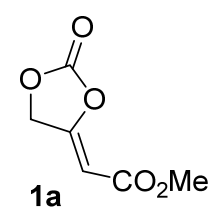

$85 \%$ yield, White solid, m.p. $115.7-116.5^{\circ} \mathrm{C}$.

${ }^{1} \mathbf{H}$ NMR $\left(400 \mathrm{MHz}, \mathrm{CDCl}_{3}\right) \delta 5.26(\mathrm{t}, J=1.9 \mathrm{~Hz}, 1 \mathrm{H}), 5.11(\mathrm{~d}, J=1.9 \mathrm{~Hz}, 2 \mathrm{H}), 3.76(\mathrm{~s}, 3 \mathrm{H})$.

${ }^{13} \mathbf{C}$ NMR $\left(100 \mathrm{MHz}, \mathrm{CDCl}_{3}\right) \delta 163.0,153.9,151.3,94.7,68.0,51.9$. 
HRMS (ESI) calcd. for $\mathrm{C}_{6} \mathrm{H}_{6} \mathrm{NaO}_{5}{ }^{+}(\mathrm{M}+\mathrm{Na})^{+}:$181.0107, Found: 181.0107.

\section{Ethyl (Z)-2-(2-oxo-1,3-dioxolan-4-ylidene)acetate (1b)}

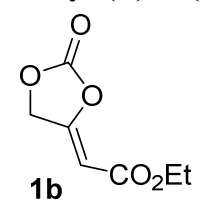

$62 \%$ yield, White solid, m.p. $91.7-92.4^{\circ} \mathrm{C}$.

${ }^{1} \mathbf{H}$ NMR $\left(400 \mathrm{MHz}, \mathrm{CDCl}_{3}\right) \delta 5.24(\mathrm{t}, J=2.0 \mathrm{~Hz}, 1 \mathrm{H}), 5.09(\mathrm{~d}, J=2.0 \mathrm{~Hz}, 2 \mathrm{H}), 4.23(\mathrm{q}, J=7.1 \mathrm{~Hz}$, $2 \mathrm{H}), 1.30(\mathrm{t}, J=7.1 \mathrm{~Hz}, 3 \mathrm{H})$.

${ }^{13}$ C NMR $\left(100 \mathrm{MHz}, \mathrm{CDCl}_{3}\right) \delta 162.6,153.6,151.3,95.2,67.9,60.9,14.2$.

HRMS (ESI) calcd. for $\mathrm{C}_{7} \mathrm{H}_{8} \mathrm{NaO}_{5}^{+}(\mathrm{M}+\mathrm{Na})^{+}:$195.0264, Found: 195.0265.

\section{Preparation of Ligands}

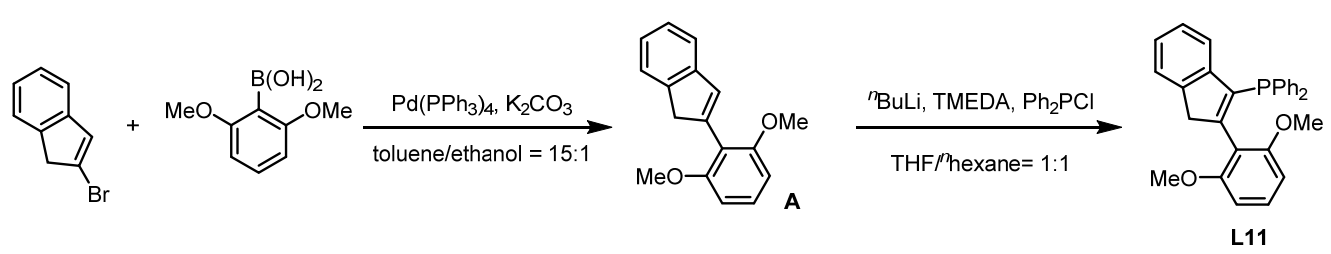

To an oven-dried round bottom flask, $\mathrm{Pd}\left(\mathrm{PPh}_{3}\right)_{4}(680 \mathrm{mg}, 0.6 \mathrm{mmol}), 2$-bromo- $1 H$-indene $(3.9 \mathrm{~g}$, $20 \mathrm{mmol})$, (2,6-dimethoxyphenyl)boronic acid (4 g, $22 \mathrm{mmol}), \mathrm{K}_{2} \mathrm{CO}_{3}(5.5 \mathrm{~g}, 40 \mathrm{mmol})$ were added successively, followed with toluene/ethanol $(128 \mathrm{~mL}, 15: 1 \mathrm{v} / \mathrm{v})$. Then the mixtures were stirred at $100{ }^{\circ} \mathrm{C}$ for $12 \mathrm{~h}$. The resulting black solution was quenched with saturated $\mathrm{NH}_{4} \mathrm{Cl}$ solution and then extracted with $\mathrm{CH}_{2} \mathrm{Cl}_{2}$. The combined organic phase was washed by saturated brine, dried over $\mathrm{MgSO}_{4}$, and evaporated under reduced pressure to give crude product, which was purified by column chromatography to give pure cross-coupling product $\mathbf{A}$.

To a solution of $\mathbf{A}(2.5 \mathrm{~g}, 10 \mathrm{mmol})$ in $\mathrm{THF} /{ }^{n}$ hexane $(40 \mathrm{~mL}, 1: 1 \mathrm{v} / \mathrm{v})$ at room temperature, TMEDA (2.2 mL, $15 \mathrm{mmol}$ ) was added, followed with ${ }^{n} \mathrm{BuLi}(2.5 \mathrm{M}$ solution in hexane, $6 \mathrm{~mL})$. The mixtures were stirred at ambient temperature for $12 \mathrm{~h}$. Then $\mathrm{Ph}_{2} \mathrm{PCl}(1.9 \mathrm{~mL}, 11 \mathrm{mmol})$ was added and the mixtures were stirred for additional $12 \mathrm{~h}$. The reaction mixtures were quenched by adding saturated $\mathrm{NH}_{4} \mathrm{Cl}$ solution and extracted with EtOAc. The combined organic layer was washed with saturated brine, dried over $\mathrm{MgSO}_{4}$, and evaporated under reduced pressure to give crude product, which was purified by column chromatography to give pure L11. ${ }^{4,5}$

L11, 43\% yield, White solid, $\mathrm{R}_{f}=0.4($ EtOAc/petroleum ether $=1: 25)$, m.p. $147.1-147.5^{\circ} \mathrm{C}$.

${ }^{1} \mathbf{H}$ NMR $\left(400 \mathrm{MHz}, \mathrm{CDCl}_{3}\right) \delta 7.56-7.45(\mathrm{~m}, 5 \mathrm{H}), 7.35-7.27(\mathrm{~m}, 7 \mathrm{H}), 7.16(\mathrm{td}, J=7.4,0.9 \mathrm{~Hz}, 1 \mathrm{H})$, $7.02(\mathrm{t}, J=7.5 \mathrm{~Hz}, 1 \mathrm{H}), 6.86(\mathrm{~d}, J=7.7 \mathrm{~Hz}, 1 \mathrm{H}), 6.58(\mathrm{~d}, J=8.4 \mathrm{~Hz}, 2 \mathrm{H}), 3.92(\mathrm{~s}, 2 \mathrm{H}), 3.60(\mathrm{~s}, 6 \mathrm{H})$.

${ }^{13}$ C NMR (100 MHz, $\left.\mathrm{CDCl}_{3}\right) \delta 157.7,154.9(\mathrm{~d}, J=33.2 \mathrm{~Hz}), 145.9(\mathrm{~d}, J=1.2 \mathrm{~Hz}), 144.3(\mathrm{~d}, J=2.2$ $\mathrm{Hz}), 136.5$ (d, $J=10.1 \mathrm{~Hz}), 135.0$ (d, $J=13.5 \mathrm{~Hz}), 132.5$ (d, $J=18.0 \mathrm{~Hz}), 129.2,127.9(\mathrm{~d}, J=6.1 \mathrm{~Hz})$, 127.6, 125.6, 123.9, 123.3, 122.7, 115.3 (d, $J=5.8 \mathrm{~Hz}), 103.5,55.2,43.5$ (d, $J=7.0 \mathrm{~Hz})$.

${ }^{31} \mathbf{P}$ NMR $\left(162 \mathrm{MHz}, \mathrm{CDCl}_{3}\right) \delta-24.5$.

HRMS (ESI) calcd. for $\mathrm{C}_{29} \mathrm{H}_{26} \mathrm{O}_{2} \mathrm{P}^{+}(\mathrm{M}+\mathrm{H})^{+}: 437.1665$, Found: 437.1665 . 

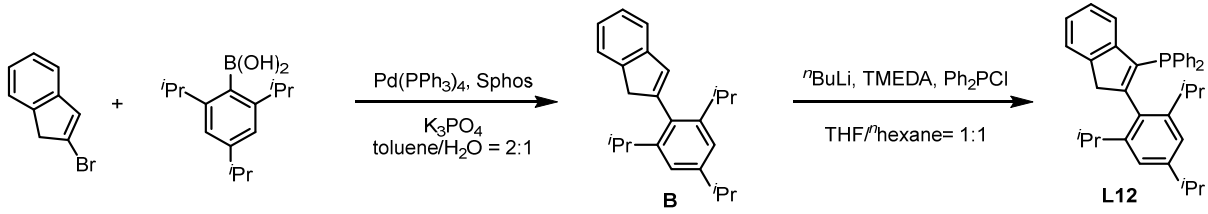

To an oven-dried round bottom flask, $\mathrm{Pd}\left(\mathrm{PPh}_{3}\right)_{4}(267 \mathrm{mg}, 0.23 \mathrm{mmol})$, Sphos (189 mg, 0.46 mmol), 2-bromo-1H-indene ( $1.5 \mathrm{~g}, 7.69 \mathrm{mmol}),(2,4,6$-triisopropylphenyl)boronic acid (2.67 $\mathrm{g}$, $10.77 \mathrm{mmol}), \mathrm{K}_{3} \mathrm{PO}_{4}(3.27 \mathrm{~g}, 15.38 \mathrm{~mol})$ were added successively, followed with toluene/ $\mathrm{H}_{2} \mathrm{O}(30$ $\mathrm{mL}, 15: 1 \mathrm{v} / \mathrm{v})$. Then the mixtures were stirred at $100^{\circ} \mathrm{C}$ for $12 \mathrm{~h}$. The resulting black solution was extracted with $\mathrm{CH}_{2} \mathrm{Cl}_{2}$. The combined organic phase was washed by saturated brine, dried over $\mathrm{MgSO}_{4}$, and evaporated under reduced pressure to give crude product, which was purified by column chromatography to give pure cross-coupling product $\mathbf{B}$.

To a solution of $\mathbf{B}(1 \mathrm{~g}, 3.14 \mathrm{mmol})$ in $\mathrm{THF} /{ }^{n}$ hexane $(1: 1) 12 \mathrm{~mL}$ at room temperature, TMEDA $(0.79 \mathrm{~mL}, 5.34 \mathrm{mmol})$ was added, followed with ${ }^{n} \mathrm{BuLi}(2.5 \mathrm{M}$ solution in hexane, $2.1 \mathrm{~mL})$. The mixtures were stirred at ambient temperature for $12 \mathrm{~h}$. Then $\mathrm{Ph}_{2} \mathrm{PCl}(0.68 \mathrm{~mL}, 3.77 \mathrm{mmol})$ was added and the mixtures were stirred for additional $12 \mathrm{~h}$. The reaction mixtures were quenched by adding saturated $\mathrm{NH}_{4} \mathrm{Cl}$ solution and extracted with EtOAc. The combined organic layer was washed with saturated brine, dried over $\mathrm{MgSO}_{4}$, and evaporated under reduced pressure to give crude product, which was purified by column chromatography to give pure L12. ${ }^{4,5}$

L12, 37\% yield, Yellow solid, $\mathrm{R}_{f}=0.2$ (petroleum ether), m.p. $148.7-149.3^{\circ} \mathrm{C}$.

${ }^{1} \mathbf{H}$ NMR $\left(400 \mathrm{MHz}, \mathrm{CDCl}_{3}\right) \delta 7.54(\mathrm{~d}, J=7.4 \mathrm{~Hz}, 1 \mathrm{H}), 7.40(\mathrm{td}, J=7.0,3.2 \mathrm{~Hz}, 4 \mathrm{H}), 7.33-7.27(\mathrm{~m}$, $6 \mathrm{H}), 7.19(\mathrm{t}, J=7.4 \mathrm{~Hz}, 1 \mathrm{H}), 7.07-6.99(\mathrm{~m}, 3 \mathrm{H}), 6.71(\mathrm{~d}, J=7.7 \mathrm{~Hz}, 1 \mathrm{H}), 3.74(\mathrm{~s}, 2 \mathrm{H}), 2.95(\mathrm{dt}, J=$ $13.8,6.9 \mathrm{~Hz}, 1 \mathrm{H}), 2.83(\mathrm{dt}, J=13.6,6.8 \mathrm{~Hz}, 2 \mathrm{H}), 1.32(\mathrm{~d}, J=6.9 \mathrm{~Hz}, 6 \mathrm{H}), 1.18(\mathrm{~d}, J=6.9 \mathrm{~Hz}, 6 \mathrm{H})$, $0.94(\mathrm{~d}, J=6.8 \mathrm{~Hz}, 6 \mathrm{H})$.

${ }^{13}$ C NMR (100 MHz, $\left.\mathrm{CDCl}_{3}\right) \delta 163.2(\mathrm{~d}, J=39.8 \mathrm{~Hz}), 148.2,146.3,145.7(\mathrm{~d}, J=5.4 \mathrm{~Hz}), 143.4$, $136.5(\mathrm{~d}, J=11.4 \mathrm{~Hz}), 135.6(\mathrm{~d}, J=14.4 \mathrm{~Hz}), 132.3(\mathrm{~d}, J=17.6 \mathrm{~Hz}), 131.5(\mathrm{~d}, J=6.7 \mathrm{~Hz}), 128.3(\mathrm{~d}, J$ $=5.8 \mathrm{~Hz}), 127.8,126.2,124.3,123.4(\mathrm{~d}, J=17.9 \mathrm{~Hz}), 120.9,46.7(\mathrm{~d}, J=7.5 \mathrm{~Hz}), 34.1,30.9,25.4,23.9$, $23.8(\mathrm{~d}, J=1.7 \mathrm{~Hz})$.

${ }^{31} \mathbf{P}$ NMR $\left(162 \mathrm{MHz}, \mathrm{CDCl}_{3}\right) \delta$-28.9.

HRMS (ESI) calcd. for $\mathrm{C}_{36} \mathrm{H}_{40} \mathrm{P}^{+}(\mathrm{M}+\mathrm{H})^{+}:$503.2862, Found: 503.2862.

\section{General procedure for $(3+2)$ cycloaddition}

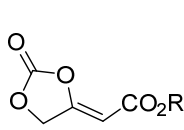

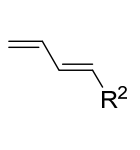

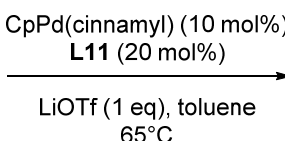

$65^{\circ} \mathrm{C}$

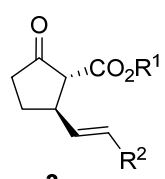

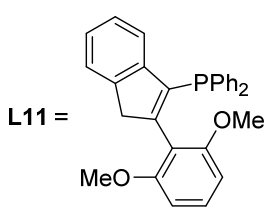

In a glovebox, CpPd(cinnamyl) $(2.9 \mathrm{mg}, 0.01 \mathrm{mmol})$ and $\mathbf{L 1 1}(8.7 \mathrm{mg}, 0.02 \mathrm{mmol})$ were dissolved in toluene $(3.5 \mathrm{~mL})$ in a sealing tube and the mixtures were stirred for $5 \mathrm{~h}$ at room temperature. Then the starting material $1(0.1 \mathrm{mmol})$ and 1,3-diene $2(0.2 \mathrm{mmol})$ were added, followed with LiOTf $(15.6 \mathrm{mg}, 0.1 \mathrm{mmol})$. The tube was then sealed and removed from the glovebox and placed in a preheated oil bath $\left(65^{\circ} \mathrm{C}\right)$ for $48 \mathrm{~h}$. The resulting mixture was concentrated under reduced pressure, and purified by column chromatography to give the corresponding $(3+2)$ cycloaddition 
product 3 .

\section{Methyl (E)-2-oxo-5-styrylcyclopentane-1-carboxylate (3a)}

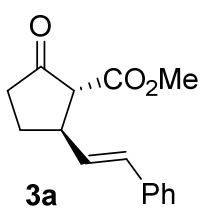

$89 \%$, White solid, $\mathrm{R}_{f}=0.2($ EtOAc/petroleum ether $=1: 10)$, m.p. $93.1-94.3^{\circ} \mathrm{C}$.

${ }^{1} \mathbf{H}$ NMR $\left(400 \mathrm{MHz}, \mathrm{CDCl}_{3}\right) \delta 7.39-7.28(\mathrm{~m}, 4 \mathrm{H}), 7.24(\mathrm{t}, J=7.2 \mathrm{~Hz}, 1 \mathrm{H}), 6.53(\mathrm{~d}, J=15.8 \mathrm{~Hz}, 1 \mathrm{H})$, $6.18(\mathrm{dd}, J=15.8,7.5 \mathrm{~Hz}, 1 \mathrm{H}), 3.76(\mathrm{~s}, 3 \mathrm{H}), 3.44-3.33(\mathrm{~m}, 1 \mathrm{H}), 3.12(\mathrm{~d}, J=11.6 \mathrm{~Hz}, 1 \mathrm{H}), 2.52(\mathrm{dd}, J$ $=18.1,8.4 \mathrm{~Hz}, 1 \mathrm{H}), 2.45-2.36(\mathrm{~m}, 1 \mathrm{H}), 2.36-2.27(\mathrm{~m}, 1 \mathrm{H}), 1.87-1.73(\mathrm{~m}, 1 \mathrm{H})$.

${ }^{13}$ C NMR $\left(100 \mathrm{MHz}, \mathrm{CDCl}_{3}\right) \delta 210.6,169.0,136.6,131.3,129.6,128.6,127.6,126.2,61.2,52.5,44.4$, 38.1, 27.7.

HRMS (ESI) calcd. for $\mathrm{C}_{15} \mathrm{H}_{16} \mathrm{NaO}_{3}{ }^{+}(\mathrm{M}+\mathrm{Na})^{+}: 267.0992$, Found: 267.0989.

\section{Ethyl (E)-2-oxo-5-styrylcyclopentane-1-carboxylate (3b)}

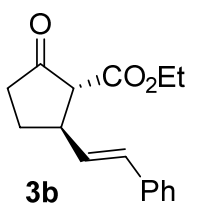

$69 \%$ yield, Light yellow solid, $\mathrm{R}_{f}=0.2($ EtOAc/petroleum ether $=1: 10)$, m.p. $50.8-52.6^{\circ} \mathrm{C}$.

${ }^{1} \mathbf{H}$ NMR $\left(400 \mathrm{MHz}, \mathrm{CDCl}_{3}\right) \delta 7.39-7.28(\mathrm{~m}, 4 \mathrm{H}), 7.26-7.20(\mathrm{~m}, 1 \mathrm{H}), 6.52(\mathrm{~d}, J=15.8 \mathrm{~Hz}, 1 \mathrm{H})$, $6.18(\mathrm{dd}, J=15.8,7.4 \mathrm{~Hz}, 1 \mathrm{H}), 4.30-4.15(\mathrm{~m}, 2 \mathrm{H}), 3.44-3.31(\mathrm{~m}, 1 \mathrm{H}), 3.08(\mathrm{~d}, J=11.6 \mathrm{~Hz}, 1 \mathrm{H})$, $2.50(\mathrm{dd}, J=18.2,8.4 \mathrm{~Hz}, 1 \mathrm{H}), 2.40(\mathrm{dd}, J=18.7,8.3 \mathrm{~Hz}, 1 \mathrm{H}), 2.35-2.27(\mathrm{~m}, 1 \mathrm{H}), 1.79(\mathrm{dt}, J=22.2$, $11.0 \mathrm{~Hz}, 1 \mathrm{H}), 1.28(\mathrm{t}, J=7.2 \mathrm{~Hz}, 3 \mathrm{H})$.

${ }^{13} \mathrm{C}$ NMR $\left(100 \mathrm{MHz}, \mathrm{CDCl}_{3}\right) \delta 210.7,168.6,136.6,131.2,129.7,128.6,127.6,126.2,61.4,61.3,44.4$, $38.1,27.7,14.2$.

HRMS (ESI) calcd. for $\mathrm{C}_{16} \mathrm{H}_{18} \mathrm{NaO}_{3}{ }^{+}(\mathrm{M}+\mathrm{Na})^{+}: 281.1148$, Found: 281.1145.

analytical data in agreement with literature. ${ }^{6}$

\section{Methyl (E)-2-(4-fluorostyryl)-5-oxocyclopentane-1-carboxylate (3c)}

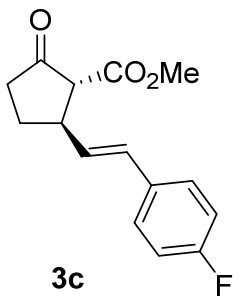

$78 \%$ yield, White solid, $\mathrm{R}_{f}=0.1$ (EtOAc/petroleum ether $\left.=1: 10\right)$, m.p. $90.1-91.4^{\circ} \mathrm{C}$.

${ }^{1} \mathbf{H}$ NMR (400 MHz, $\left.\mathrm{CDCl}_{3}\right) \delta 7.37-7.28(\mathrm{~m}, 2 \mathrm{H}), 7.00(\mathrm{t}, J=7.6 \mathrm{~Hz}, 2 \mathrm{H}), 6.49(\mathrm{~d}, J=15.7 \mathrm{~Hz}, 1 \mathrm{H})$, $6.08(\mathrm{dd}, J=15.8,7.5 \mathrm{~Hz}, 1 \mathrm{H}), 3.76(\mathrm{~s}, 3 \mathrm{H}), 3.44-3.30(\mathrm{~m}, 1 \mathrm{H}), 3.10(\mathrm{~d}, J=11.6 \mathrm{~Hz}, 1 \mathrm{H}), 2.52(\mathrm{dd}, J$ $=18.4,8.3 \mathrm{~Hz}, 1 \mathrm{H}), 2.45-2.37(\mathrm{~m}, 1 \mathrm{H}), 2.35-2.25(\mathrm{~m}, 1 \mathrm{H}), 1.86-1.72(\mathrm{~m}, 1 \mathrm{H})$. 
${ }^{13}$ C NMR $\left(100 \mathrm{MHz}, \mathrm{CDCl}_{3}\right) \delta 210.4,169.0,162.3(\mathrm{~d}, J=246.8 \mathrm{~Hz}), 132.8(\mathrm{~d}, J=3.0 \mathrm{~Hz}), 130.1$, $129.4(\mathrm{~d}, J=1.8 \mathrm{~Hz}), 127.8(\mathrm{~d}, J=7.9 \mathrm{~Hz}), 115.5$ (d, $J=21.7 \mathrm{~Hz}), 61.2,52.5,44.3,38.1,27.7$.

${ }^{19}$ F NMR $\left(376 \mathrm{MHz}, \mathrm{CDCl}_{3}\right) \delta-118.6$.

HRMS (ESI) calcd. for $\mathrm{C}_{15} \mathrm{H}_{15} \mathrm{FNaO}_{3}{ }^{+}(\mathrm{M}+\mathrm{Na})^{+}:$285.0897, Found: 285.0896.

Methyl (E)-2-(4-chlorostyryl)-5-oxocyclopentane-1-carboxylate (3d)

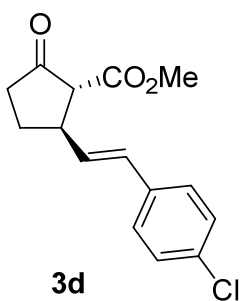

$33 \%$ yield, Light yellow solid, $\mathrm{R}_{f}=0.1$, (EtOAc/petroleum ether $\left.=1: 10\right)$, m.p. $89.4-90.6^{\circ} \mathrm{C}$.

${ }^{1}$ H NMR (400 MHz, $\left.\mathrm{CDCl}_{3}\right) \delta 7.28(\mathrm{~s}, 4 \mathrm{H}), 6.48(\mathrm{~d}, J=15.8 \mathrm{~Hz}, 1 \mathrm{H}), 6.15(\mathrm{dd}, J=15.8,7.5 \mathrm{~Hz}, 1 \mathrm{H})$, $3.77(\mathrm{~s}, 3 \mathrm{H}), 3.46-3.31(\mathrm{~m}, 1 \mathrm{H}), 3.10(\mathrm{~d}, J=11.6 \mathrm{~Hz}, 1 \mathrm{H}), 2.52(\mathrm{dd}, J=18.2,8.4 \mathrm{~Hz}, 1 \mathrm{H}), 2.41(\mathrm{dd}, J$ $=19.0,8.2 \mathrm{~Hz}, 1 \mathrm{H}), 2.36-2.27(\mathrm{~m}, 1 \mathrm{H}), 1.79(\mathrm{dt}, J=22.3,11.1 \mathrm{~Hz}, 1 \mathrm{H})$.

${ }^{13} \mathbf{C}$ NMR $\left(100 \mathrm{MHz}, \mathrm{CDCl}_{3}\right) \delta 210.3,169.0,135.1,133.3,130.3,130.1,128.7,127.5,61.1,52.6,44.3$, $38.1,27.6$.

HRMS (ESI) calcd. for $\mathrm{C}_{15} \mathrm{H}_{15} \mathrm{ClNaO}_{3}{ }^{+}(\mathrm{M}+\mathrm{Na})^{+}: 301.0602$, Found: 301.0599 .

\section{Methyl (E)-2-oxo-5-(4-(trifluoromethyl)styryl)cyclopentane-1-carboxylate (3e)}

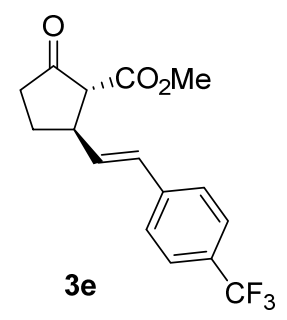

$56 \%$ yield, White solid, $\mathrm{R}_{f}=0.2($ EtOAc/petroleum ether $=1: 10)$, m.p. $115.6-117.0^{\circ} \mathrm{C}$.

${ }^{1} \mathbf{H}$ NMR $\left(400 \mathrm{MHz}, \mathrm{CDCl}_{3}\right) \delta 7.55(\mathrm{~d}, J=6.9 \mathrm{~Hz}, 2 \mathrm{H}), 7.45(\mathrm{~d}, J=7.1 \mathrm{~Hz}, 2 \mathrm{H}), 6.55(\mathrm{~d}, J=15.8 \mathrm{~Hz}$, 1H), 6.27 (dd, $J=15.8,7.4 \mathrm{~Hz}, 1 \mathrm{H}), 3.76(\mathrm{~s}, 3 \mathrm{H}), 3.49-3.34(\mathrm{~m}, 1 \mathrm{H}), 3.12(\mathrm{~d}, J=11.6 \mathrm{~Hz}, 1 \mathrm{H}), 2.53$ $(\mathrm{dd}, J=18.2,8.8 \mathrm{~Hz}, 1 \mathrm{H}), 2.47-2.26(\mathrm{~m}, 2 \mathrm{H}), 1.93-1.73(\mathrm{~m}, 1 \mathrm{H})$.

${ }^{13}$ C NMR (100 MHz, $\left.\mathrm{CDCl}_{3}\right) \delta$ 210.2, 168.9, 140.0, 132.3, 130.1, 129.4 (q, $\left.J=32.7 \mathrm{~Hz}\right), 126.4,125.5$ (q, $J=3.9 \mathrm{~Hz}), 124.1$ (q, $J=272.6 \mathrm{~Hz}), 61.0,52.6,44.3,38.1,27.5$.

${ }^{19}$ F NMR $\left(376 \mathrm{MHz}, \mathrm{CDCl}_{3}\right) \delta-66.8$.

HRMS (ESI) calcd. for $\mathrm{C}_{16} \mathrm{H}_{15} \mathrm{~F}_{3} \mathrm{NaO}_{3}{ }^{+}(\mathrm{M}+\mathrm{Na})^{+}$: 335.0866, Found: 335.0866 .

\section{Methyl (E)-4-(2-(2-(methoxycarbonyl)-3-oxocyclopentyl)vinyl)benzoate (3f)}

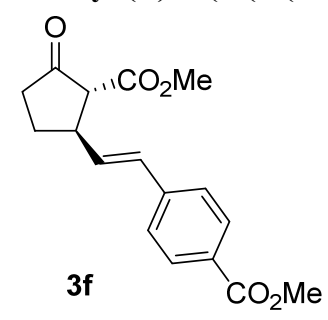


$59 \%$ yield, White solid, $\mathrm{R}_{f}=0.2$ (EtOAc/petroleum ether $\left.=1: 6\right)$, m.p. $86.1-86.3^{\circ} \mathrm{C}$.

${ }^{1} \mathbf{H}$ NMR $\left(400 \mathrm{MHz}, \mathrm{CDCl}_{3}\right) \delta 7.97(\mathrm{~d}, J=8.3 \mathrm{~Hz}, 2 \mathrm{H}), 7.41(\mathrm{~d}, J=8.3 \mathrm{~Hz}, 2 \mathrm{H}), 6.56(\mathrm{~d}, J=15.8 \mathrm{~Hz}$, $1 \mathrm{H}), 6.30(\mathrm{dd}, J=15.8,7.5 \mathrm{~Hz}, 1 \mathrm{H}), 3.90(\mathrm{~s}, 3 \mathrm{H}), 3.77$ (s, 3H), $3.47-3.36(\mathrm{~m}, 1 \mathrm{H}), 3.12(\mathrm{~d}, J=11.6$ $\mathrm{Hz}, 1 \mathrm{H}), 2.53(\mathrm{dd}, J=18.0,8.5 \mathrm{~Hz}, 1 \mathrm{H}), 2.46-2.37(\mathrm{~m}, 1 \mathrm{H}), 2.37-2.28(\mathrm{~m}, 1 \mathrm{H}), 1.89-1.73(\mathrm{~m}$, $1 \mathrm{H})$.

${ }^{13}$ C NMR $\left(100 \mathrm{MHz}, \mathrm{CDCl}_{3}\right) \delta 210.2,168.9,166.8,141.0,132.3,130.5,129.9,129.1,126.2,61.0$, 52.6, 52.1, 44.3, 38.1, 27.5.

HRMS (ESI) calcd. for $\mathrm{C}_{17} \mathrm{H}_{18} \mathrm{NaO}_{5}^{+}(\mathrm{M}+\mathrm{Na})^{+}:$325.1046, Found: 325.1045 .

Methyl (E)-2-(4-nitrostyryl)-5-oxocyclopentane-1-carboxylate (3g)

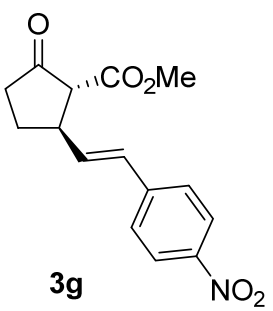

$40 \%$ yield, Light yellow solid, $\mathrm{R}_{f}=0.2($ EtOAc/petroleum ether $=1: 4)$, m.p. $93.0-93.4^{\circ} \mathrm{C}$.

${ }^{1} \mathbf{H}$ NMR $\left(400 \mathrm{MHz}, \mathrm{CDCl}_{3}\right) \delta 8.16(\mathrm{~d}, J=8.6 \mathrm{~Hz}, 2 \mathrm{H}), 7.48(\mathrm{~d}, J=8.7 \mathrm{~Hz}, 2 \mathrm{H}), 6.59(\mathrm{~d}, J=15.9 \mathrm{~Hz}$, $1 \mathrm{H}), 6.37(\mathrm{dd}, J=15.9,7.5 \mathrm{~Hz}, 1 \mathrm{H}), 3.77(\mathrm{~s}, 3 \mathrm{H}), 3.51-3.30(\mathrm{~m}, 1 \mathrm{H}), 3.14(\mathrm{~d}, J=11.6 \mathrm{~Hz}, 1 \mathrm{H}), 2.54$ $(\mathrm{dd}, J=17.9,8.4 \mathrm{~Hz}, 1 \mathrm{H}), 2.48-2.30(\mathrm{~m}, 2 \mathrm{H}), 1.92-1.75(\mathrm{~m}, 1 \mathrm{H})$.

${ }^{13}$ C NMR $\left(100 \mathrm{MHz}, \mathrm{CDCl}_{3}\right) \delta 209.7,168.7,146.9,143.0,134.6,129.5,126.8,124.0,60.8,52.6,44.2$, $38.0,27.4$.

HRMS (ESI) calcd. for $\mathrm{C}_{15} \mathrm{H}_{15} \mathrm{NNaO}_{5}^{+}(\mathrm{M}+\mathrm{Na})^{+}: 312.0842$, Found: 312.0837 .

Methyl (E)-2-(4-methoxystyryl)-5-oxocyclopentane-1-carboxylate (3h)

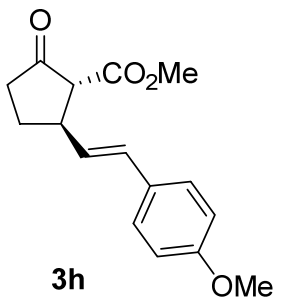

$84 \%$ yield, White solid, $\mathrm{R}_{f}=0.1$ (EtOAc/petroleum ether $\left.=1: 10\right)$, m.p. $76.7-77.6^{\circ} \mathrm{C}$.

${ }^{1} \mathbf{H}$ NMR $\left(400 \mathrm{MHz}, \mathrm{CDCl}_{3}\right) \delta 7.29(\mathrm{~d}, J=8.6 \mathrm{~Hz}, 2 \mathrm{H}), 6.85(\mathrm{~d}, J=8.6 \mathrm{~Hz}, 2 \mathrm{H}), 6.46(\mathrm{~d}, J=15.8 \mathrm{~Hz}$, $1 \mathrm{H}), 6.02(\mathrm{dd}, J=15.8,7.5 \mathrm{~Hz}, 1 \mathrm{H}), 3.80(\mathrm{~s}, 3 \mathrm{H}), 3.76(\mathrm{~s}, 3 \mathrm{H}), 3.42-3.30(\mathrm{~m}, 1 \mathrm{H}), 3.09(\mathrm{~d}, J=11.6$ $\mathrm{Hz}, 1 \mathrm{H}), 2.51(\mathrm{dd}, J=18.5,8.5 \mathrm{~Hz}, 1 \mathrm{H}), 2.45-2.35(\mathrm{~m}, 1 \mathrm{H}), 2.34-2.26(\mathrm{~m}, 1 \mathrm{H}), 1.85-1.71(\mathrm{~m}$, $1 \mathrm{H})$.

${ }^{13}$ C NMR $\left(100 \mathrm{MHz}, \mathrm{CDCl}_{3}\right) \delta 210.8,169.1,159.3,130.6,129.4,127.4,127.4,114.0,61.4,55.3,52.5$, 44.4, 38.2, 27.8 .

HRMS (ESI) calcd. for $\mathrm{C}_{16} \mathrm{H}_{18} \mathrm{NaO}_{4}^{+}(\mathrm{M}+\mathrm{Na})^{+}:$297.1097, Found: 297.1096.

\section{Methyl (E)-2-(4-methylstyryl)-5-oxocyclopentane-1-carboxylate (3i)}




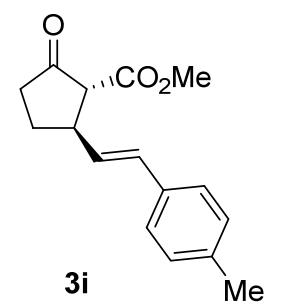

$69 \%$ yield, White solid, $\mathrm{R}_{f}=0.2$ (EtOAc/petroleum ether $\left.=1: 10\right)$, m.p. $91.9-92.5^{\circ} \mathrm{C}$.

${ }^{1} \mathbf{H}$ NMR $\left(400 \mathrm{MHz}, \mathrm{CDCl}_{3}\right) \delta 7.26(\mathrm{~d}, J=8.1 \mathrm{~Hz}, 2 \mathrm{H}), 7.12(\mathrm{~d}, J=7.9 \mathrm{~Hz}, 2 \mathrm{H}), 6.49(\mathrm{~d}, J=15.8 \mathrm{~Hz}$, $1 \mathrm{H}), 6.12$ (dd, $J=15.8,7.5 \mathrm{~Hz}, 1 \mathrm{H}), 3.76$ (s, 3H), 3.37 (ddd, $J=18.2,11.8,6.8 \mathrm{~Hz}, 1 \mathrm{H}), 3.10$ (d, $J=$ $11.6 \mathrm{~Hz}, 1 \mathrm{H}), 2.51(\mathrm{dd}, J=18.3,8.4 \mathrm{~Hz}, 1 \mathrm{H}), 2.45-2.36(\mathrm{~m}, 1 \mathrm{H}), 2.33(\mathrm{~s}, 3 \mathrm{H}), 2.32-2.26(\mathrm{~m}, 1 \mathrm{H})$, $1.86-1.73(\mathrm{~m}, 1 \mathrm{H})$.

${ }^{13}$ C NMR $\left(100 \mathrm{MHz}, \mathrm{CDCl}_{3}\right) \delta 210.8,169.1,137.5,133.8,131.1,129.2,128.5,126.1,61.3,52.5$, 44.4, 38.1, 27.7, 21.1.

HRMS (ESI) calcd. for $\mathrm{C}_{16} \mathrm{H}_{18} \mathrm{NaO}_{3}{ }^{+}(\mathrm{M}+\mathrm{Na})^{+}:$: 281.1148, Found: 281.1144.

Methyl (E)-2-(2-fluorostyryl)-5-oxocyclopentane-1-carboxylate (3j)

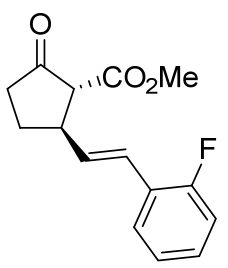

3j

$73 \%$, Colorless oil, $\mathrm{R}_{f}=0.2($ EtOAc/petroleum ether $=1: 10)$.

${ }^{1} \mathbf{H}$ NMR $\left(400 \mathrm{MHz}, \mathrm{CDCl}_{3}\right) \delta 7.42(\mathrm{t}, J=7.3 \mathrm{~Hz}, 1 \mathrm{H}), 7.20(\mathrm{dd}, J=13.3,6.1 \mathrm{~Hz}, 1 \mathrm{H}), 7.08(\mathrm{t}, J=7.5$ $\mathrm{Hz}, 1 \mathrm{H}), 7.05-6.98(\mathrm{~m}, 1 \mathrm{H}), 6.67$ (d, $J=16.0 \mathrm{~Hz}, 1 \mathrm{H}), 6.27(\mathrm{dd}, J=16.0,7.5 \mathrm{~Hz}, 1 \mathrm{H}), 3.77$ (s, 3H), $3.40(\mathrm{ddd}, J=17.8,11.4,6.7 \mathrm{~Hz}, 1 \mathrm{H}), 3.12(\mathrm{~d}, J=11.6 \mathrm{~Hz}, 1 \mathrm{H}), 2.52(\mathrm{dd}, J=17.9,8.4 \mathrm{~Hz}, 1 \mathrm{H}), 2.46-$ $2.37(\mathrm{~m}, 1 \mathrm{H}), 2.37-2.28(\mathrm{~m}, 1 \mathrm{H}), 1.87-1.74(\mathrm{~m}, 1 \mathrm{H})$.

${ }^{13}$ C NMR (100 MHz, $\left.\mathrm{CDCl}_{3}\right) \delta 210.4,169.0,160.2(\mathrm{~d}, J=249.6 \mathrm{~Hz}), 132.3(\mathrm{~d}, J=4.9 \mathrm{~Hz}), 128.9$ (d, $J$ $=8.3 \mathrm{~Hz}), 127.4(\mathrm{~d}, J=3.5 \mathrm{~Hz}), 124.4(\mathrm{~d}, J=12.1 \mathrm{~Hz}), 124.1(\mathrm{~d}, J=3.5 \mathrm{~Hz}), 123.9(\mathrm{~d}, J=3.2 \mathrm{~Hz})$, $115.7(\mathrm{~d}, J=22.1 \mathrm{~Hz}), 61.1,52.5,44.7,38.1,27.6$.

${ }^{19}$ F NMR $\left(376 \mathrm{MHz}, \mathrm{CDCl}_{3}\right) \delta-122.2$.

HRMS (ESI) calcd. for $\mathrm{C}_{15} \mathrm{H}_{15} \mathrm{FNaO}_{3}{ }^{+}(\mathrm{M}+\mathrm{Na})^{+}:$285.0897, Found: 285.0893 .

Methyl (E)-2-(2-methylstyryl)-5-oxocyclopentane-1-carboxylate (3k)

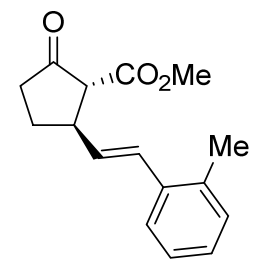

3k

$42 \%$, Light red oil, $\mathrm{R}_{f}=0.2($ EtOAc/petroleum ether $=1: 10)$.

${ }^{1} \mathbf{H}$ NMR $\left(400 \mathrm{MHz}, \mathrm{CDCl}_{3}\right) \delta 7.47-7.38(\mathrm{~m}, 1 \mathrm{H}), 7.22-7.09(\mathrm{~m}, 3 \mathrm{H}), 6.74(\mathrm{~d}, J=15.7 \mathrm{~Hz}, 1 \mathrm{H})$, $6.04(\mathrm{dd}, J=15.6,7.5 \mathrm{~Hz}, 1 \mathrm{H}), 3.77(\mathrm{~s}, 3 \mathrm{H}), 3.48-3.35(\mathrm{~m}, 1 \mathrm{H}), 3.13(\mathrm{~d}, J=11.6 \mathrm{~Hz}, 1 \mathrm{H}), 2.52(\mathrm{dd}, J$ $=17.8,8.4 \mathrm{~Hz}, 1 \mathrm{H}), 2.46-2.35(\mathrm{~m}, 2 \mathrm{H}), 2.32(\mathrm{~s}, 3 \mathrm{H}), 1.88-1.74(\mathrm{~m}, 1 \mathrm{H})$. 
${ }^{13} \mathbf{C}$ NMR $\left(100 \mathrm{MHz}, \mathrm{CDCl}_{3}\right) \delta 210.7,169.1,135.8,135.3,131.0,130.3,129.2,127.6,126.1,125.5$, 61.3, 52.5, 44.8, 38.2, 27.8, 19.7 .

HRMS (ESI) calcd. for $\mathrm{C}_{16} \mathrm{H}_{18} \mathrm{NaO}_{3}{ }^{+}(\mathrm{M}+\mathrm{Na})^{+}: 281.1148$, Found: 281.1145 .

Methyl (E)-2-(3-methylstyryl)-5-oxocyclopentane-1-carboxylate (3I)

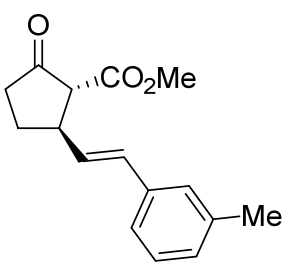

3!

$79 \%$, White solid, $\mathrm{R}_{f}=0.2($ EtOAc/petroleum ether $=1: 10)$, m.p. $70.6-71.5^{\circ} \mathrm{C}$.

${ }^{1} \mathbf{H}$ NMR $\left(400 \mathrm{MHz}, \mathrm{CDCl}_{3}\right) \delta 7.23-7.11(\mathrm{~m}, 3 \mathrm{H}), 7.06(\mathrm{~d}, J=7.1 \mathrm{~Hz}, 1 \mathrm{H}), 6.50(\mathrm{~d}, J=15.8 \mathrm{~Hz}, 1 \mathrm{H})$, $6.16(\mathrm{dd}, J=15.8,7.5 \mathrm{~Hz}, 1 \mathrm{H}), 3.76(\mathrm{~s}, 3 \mathrm{H}), 3.49-3.33(\mathrm{~m}, 1 \mathrm{H}), 3.11(\mathrm{~d}, J=11.6 \mathrm{~Hz}, 1 \mathrm{H}), 2.51(\mathrm{dd}, J$ $=18.2,8.4 \mathrm{~Hz}, 1 \mathrm{H}), 2.46-2.37(\mathrm{~m}, 1 \mathrm{H}), 2.34(\mathrm{~s}, 3 \mathrm{H}), 2.32-2.26(\mathrm{~m}, 1 \mathrm{H}), 1.89-1.71(\mathrm{~m}, 1 \mathrm{H})$.

${ }^{13} \mathbf{C}$ NMR $\left(100 \mathrm{MHz}, \mathrm{CDCl}_{3}\right) \delta 210.7,169.1,138.2,136.6,131.3,129.4,128.5,128.4,127.0,123.4$, 61.2, 52.5, 44.4, 38.2, 27.7, 21.3.

HRMS (ESI) calcd. for $\mathrm{C}_{16} \mathrm{H}_{18} \mathrm{NaO}_{3}^{+}(\mathrm{M}+\mathrm{Na})^{+}$: 281.1148, Found: 281.1146 .

Methyl (E)-2-(3-fluorostyryl)-5-oxocyclopentane-1-carboxylate (3m)

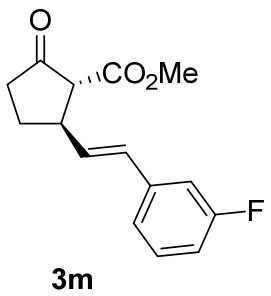

$76 \%$ yield, Light yellow solid, $\mathrm{R}_{f}=0.2($ EtOAc/petroleum ether $=1: 10)$, m.p. $65.5-66.0^{\circ} \mathrm{C}$.

${ }^{1} \mathbf{H}$ NMR $\left(400 \mathrm{MHz}, \mathrm{CDCl}_{3}\right) \delta 7.34-7.27(\mathrm{~m}, 1 \mathrm{H}), 7.14(\mathrm{~d}, J=7.6 \mathrm{~Hz}, 1 \mathrm{H}), 7.09(\mathrm{~d}, J=10.1 \mathrm{~Hz}, 1 \mathrm{H})$, $6.95(\mathrm{t}, J=8.3 \mathrm{~Hz}, 1 \mathrm{H}), 6.52(\mathrm{~d}, J=15.8 \mathrm{~Hz}, 1 \mathrm{H}), 6.20(\mathrm{dd}, J=15.8,7.5 \mathrm{~Hz}, 1 \mathrm{H}), 3.79$ (s, 3H), $3.50-$ $3.34(\mathrm{~m}, 1 \mathrm{H}), 3.13$ (d, $J=11.6 \mathrm{~Hz}, 1 \mathrm{H}), 2.54$ (dd, $J=18.6,8.7 \mathrm{~Hz}, 1 \mathrm{H}), 2.49-2.39$ (m, 1H), $2.39-$ $2.29(\mathrm{~m}, 1 \mathrm{H}), 1.90-1.75(\mathrm{~m}, 1 \mathrm{H})$.

${ }^{13}$ C NMR $\left(100 \mathrm{MHz}, \mathrm{CDCl}_{3}\right) \delta 210.3,168.9,163.1(\mathrm{~d}, J=245.5 \mathrm{~Hz}), 138.9(\mathrm{~d}, J=7.7 \mathrm{~Hz}), 131.0$, 130.3 (d, $J=2.5 \mathrm{~Hz}), 130.0$ (d, $J=8.4 \mathrm{~Hz}), 122.2$ (d, $J=2.7 \mathrm{~Hz}), 114.4$ (d, $J=21.4 \mathrm{~Hz}), 112.7$ (d, $J=$ $21.8 \mathrm{~Hz}), 61.0,52.6,44.2,38.1,27.6$.

${ }^{19} \mathbf{F}$ NMR $\left(376 \mathrm{MHz}, \mathrm{CDCl}_{3}\right) \delta-117.7$.

HRMS (ESI) calcd. for $\mathrm{C}_{15} \mathrm{H}_{15} \mathrm{FNaO}_{3}{ }^{+}(\mathrm{M}+\mathrm{Na})^{+}: 285.0897$, Found: 285.0895 .

Methyl (E)-2-(2-(naphthalen-2-yl)vinyl)-5-oxocyclopentane-1-carboxylate (3n) 


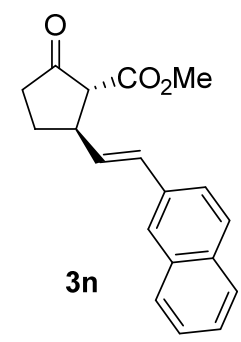

$79 \%$ yield, Light yellow solid, $\mathrm{R}_{f}=0.4$ (EtOAc/petroleum ether $\left.=1: 6\right)$, m.p. $107.8-108.6^{\circ} \mathrm{C}$.

${ }^{1} \mathbf{H}$ NMR $\left(400 \mathrm{MHz}, \mathrm{CDCl}_{3}\right) \delta 7.85-7.76(\mathrm{~m}, 3 \mathrm{H}), 7.72(\mathrm{~s}, 1 \mathrm{H}), 7.58(\mathrm{~d}, J=8.6 \mathrm{~Hz}, 1 \mathrm{H}), 7.51-7.40$ $(\mathrm{m}, 2 \mathrm{H}), 6.69(\mathrm{~d}, J=15.8 \mathrm{~Hz}, 1 \mathrm{H}), 6.30(\mathrm{dd}, J=15.8,7.5 \mathrm{~Hz}, 1 \mathrm{H}), 3.78(\mathrm{~s}, 3 \mathrm{H}), 3.52-3.38(\mathrm{~m}, 1 \mathrm{H})$, $3.16(\mathrm{~d}, J=11.6 \mathrm{~Hz}, 1 \mathrm{H}), 2.54(\mathrm{dd}, J=17.8,8.4 \mathrm{~Hz}, 1 \mathrm{H}), 2.49-2.29(\mathrm{~m}, 2 \mathrm{H}), 1.90-1.76(\mathrm{~m}, 1 \mathrm{H})$. ${ }^{13} \mathbf{C}$ NMR $\left(100 \mathrm{MHz}, \mathrm{CDCl}_{3}\right) \delta 210.6,169.1,134.0,133.5,133.0,131.4,130.0,128.2,127.9,127.6$, $126.3,126.2,125.9,123.3,61.2,52.5,44.5,38.2,27.7$.

HRMS (ESI) calcd. for $\mathrm{C}_{19} \mathrm{H}_{18} \mathrm{NaO}_{3}{ }^{+}(\mathrm{M}+\mathrm{Na})^{+}: 317.1148$, Found: 317.1146 .

Methyl (E)-2-(2-(naphthalen-1-yl)vinyl)-5-oxocyclopentane-1-carboxylate (3o)

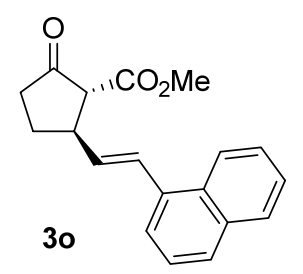

$61 \%$ yield, Orange oil, $\mathrm{R}_{f}=0.4($ EtOAc/petroleum ether $=1: 6)$.

${ }^{1} \mathbf{H}$ NMR $\left(400 \mathrm{MHz}, \mathrm{CDCl}_{3}\right) \delta 8.06(\mathrm{~d}, J=7.7 \mathrm{~Hz}, 1 \mathrm{H}), 7.88-7.83(\mathrm{~m}, 1 \mathrm{H}), 7.78(\mathrm{~d}, J=8.2 \mathrm{~Hz}, 1 \mathrm{H})$, $7.57(\mathrm{~d}, J=7.1 \mathrm{~Hz}, 1 \mathrm{H}), 7.55-7.48(\mathrm{~m}, 2 \mathrm{H}), 7.48-7.41(\mathrm{~m}, 1 \mathrm{H}), 7.29(\mathrm{~d}, J=15.6 \mathrm{~Hz}, 1 \mathrm{H}), 6.20$ (dd, $J=15.5,7.5 \mathrm{~Hz}, 1 \mathrm{H}), 3.80(\mathrm{~s}, 3 \mathrm{H}), 3.60-3.45(\mathrm{~m}, 1 \mathrm{H}), 3.20(\mathrm{~d}, J=11.7 \mathrm{~Hz}, 1 \mathrm{H}), 2.68-2.35(\mathrm{~m}, 3 \mathrm{H})$, $1.95-1.81(\mathrm{~m}, 1 \mathrm{H})$.

${ }^{13}$ C NMR $\left(100 \mathrm{MHz}, \mathrm{CDCl}_{3}\right) \delta 210.6,169.1,134.4,133.6,132.9,131.0,128.6,128.5,128.0,126.1$, $125.8,125.5,123.8,123.6,61.3,52.6,44.8,38.2,27.7$.

HRMS (ESI) calcd. for $\mathrm{C}_{19} \mathrm{H}_{18} \mathrm{NaO}_{3}{ }^{+}(\mathrm{M}+\mathrm{Na})^{+}: 317.1148$, Found: 317.1147 .

Methyl (E)-2-oxo-5-(2-(1-tosyl-1H-indol-3-yl)vinyl)cyclopentane-1-carboxylate (3p)

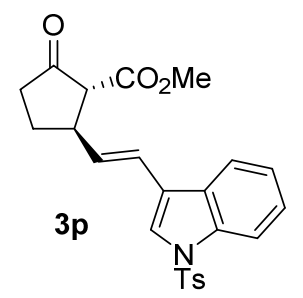

$69 \%$ yield, Light yellow solid, $\mathrm{R}_{f}=0.1($ EtOAc/petroleum ether $=1: 6)$, m.p. $77.8-78.3^{\circ} \mathrm{C}$.

${ }^{1} \mathbf{H}$ NMR $\left(400 \mathrm{MHz}, \mathrm{CDCl}_{3}\right) \delta 7.99(\mathrm{~d}, J=8.2 \mathrm{~Hz}, 1 \mathrm{H}), 7.77(\mathrm{~d}, J=8.3 \mathrm{~Hz}, 2 \mathrm{H}), 7.68(\mathrm{~d}, J=7.7 \mathrm{~Hz}$, 1H), $7.58(\mathrm{~s}, 1 \mathrm{H}), 7.36-7.30(\mathrm{~m}, 1 \mathrm{H}), 7.27(\mathrm{t}, J=7.5 \mathrm{~Hz}, 1 \mathrm{H}), 7.21(\mathrm{~d}, J=8.2 \mathrm{~Hz}, 2 \mathrm{H}), 6.59(\mathrm{~d}, J=$ $16.0 \mathrm{~Hz}, 1 \mathrm{H}), 6.23(\mathrm{dd}, J=16.0,7.5 \mathrm{~Hz}, 1 \mathrm{H}), 3.77$ (s, 3H), $3.40(\mathrm{ddd}, J=17.9,11.5,6.6 \mathrm{~Hz}, 1 \mathrm{H}), 3.13$ $(\mathrm{d}, J=11.6 \mathrm{~Hz}, 1 \mathrm{H}), 2.53(\mathrm{dd}, J=17.9,8.3 \mathrm{~Hz}, 1 \mathrm{H}), 2.46-2.38(\mathrm{~m}, 1 \mathrm{H}), 2.37-2.31(\mathrm{~m}, 4 \mathrm{H}), 1.90-$ $1.72(\mathrm{~m}, 1 \mathrm{H})$. 
${ }^{13} \mathrm{C}$ NMR $\left(100 \mathrm{MHz}, \mathrm{CDCl}_{3}\right) \delta 210.5,169.0,145.0,135.4,135.0,130.9,129.9,128.8,126.8,125.0$, 123.7, 123.4, 121.9, 120.2, 119.8, 113.7, 61.2, 52.6, 44.8, 38.1, 27.7, 21.5.

HRMS (ESI) calcd. for $\mathrm{C}_{24} \mathrm{H}_{23} \mathrm{NNaO}_{5} \mathrm{~S}^{+}(\mathrm{M}+\mathrm{Na})^{+}: 460.1189$, Found: 460.1187 .

Methyl (E)-2-oxo-5-(2-(thiophen-2-yl)vinyl)cyclopentane-1-carboxylate (3q)

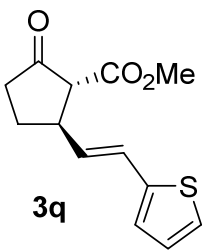

$65 \%$ yield, Yellow oil, $\mathrm{R}_{f}=0.2($ EtOAc/petroleum ether $=1: 10)$.

${ }^{1} \mathbf{H}$ NMR $\left(400 \mathrm{MHz}, \mathrm{CDCl}_{3}\right) \delta 7.14(\mathrm{~d}, J=4.8 \mathrm{~Hz}, 1 \mathrm{H}), 6.96-6.92(\mathrm{~m}, 2 \mathrm{H}), 6.65(\mathrm{~d}, J=15.6 \mathrm{~Hz}, 1 \mathrm{H})$, $5.99(\mathrm{dd}, J=15.6,7.6 \mathrm{~Hz}, 1 \mathrm{H}), 3.76(\mathrm{~s}, 3 \mathrm{H}), 3.40-3.29$ (m, 1H), 3.09 (d, $J=11.5 \mathrm{~Hz}, 1 \mathrm{H}), 2.50$ (dd, $J$ $=18.1,8.4 \mathrm{~Hz}, 1 \mathrm{H}), 2.43-2.24(\mathrm{~m}, 2 \mathrm{H}), 1.83-1.71(\mathrm{~m}, 1 \mathrm{H})$.

${ }^{13}$ C NMR $\left(100 \mathrm{MHz}, \mathrm{CDCl}_{3}\right) \delta 210.5,168.9,141.7,129.2,127.3,125.7,124.6,124.2,61.1,52.6,44.2$, 38.1, 27.6.

HRMS (ESI) calcd. for $\mathrm{C}_{13} \mathrm{H}_{14} \mathrm{NaO}_{3} \mathrm{~S}^{+}(\mathrm{M}+\mathrm{Na})^{+}: 273.0556$, Found: 273.0555 .

Methyl (E)-2-(2-ferrocenevinyl)-5-oxocyclopentane-1-carboxylate (3r)

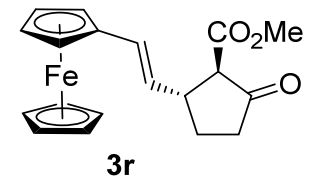

$59 \%$ yield, Brown oil, $\mathrm{R}_{f}=0.2($ EtOAc/petroleum ether $=1: 10)$.

${ }^{1} \mathrm{H}$ NMR $\left(400 \mathrm{MHz}, \mathrm{CDCl}_{3}\right) \delta 6.25(\mathrm{~d}, J=15.6 \mathrm{~Hz}, 1 \mathrm{H}), 5.72(\mathrm{dd}, J=15.6,7.7 \mathrm{~Hz}, 1 \mathrm{H}), 4.35(\mathrm{~s}, 1 \mathrm{H})$, $4.30(\mathrm{~s}, 1 \mathrm{H}), 4.22(\mathrm{~s}, 2 \mathrm{H}), 4.08(\mathrm{~s}, 5 \mathrm{H}), 3.78(\mathrm{~s}, 3 \mathrm{H}), 3.32-3.18(\mathrm{~m}, 1 \mathrm{H}), 3.05(\mathrm{~d}, J=11.7 \mathrm{~Hz}, 1 \mathrm{H})$, $2.49(\mathrm{dd}, J=18.6,8.5 \mathrm{~Hz}, 1 \mathrm{H}), 2.42-2.21(\mathrm{~m}, 2 \mathrm{H}), 1.79-1.66(\mathrm{~m}, 1 \mathrm{H})$.

${ }^{13}$ C NMR $\left(100 \mathrm{MHz}, \mathrm{CDCl}_{3}\right) \delta 211.0,169.2,129.0,126.5,69.4,68.9,68.8,67.2,66.3,61.5,52.4,44.8$, 38.2, 27.9.

HRMS (ESI) calcd. for $\mathrm{C}_{19} \mathrm{H}_{21} \mathrm{FeO}_{3}{ }^{+}(\mathrm{M}+\mathrm{H})^{+}:$353.0835, Found: 353.0835.

Methyl (E)-2-(2-cyclohexylvinyl)-5-oxocyclopentane-1-carboxylate (3s)

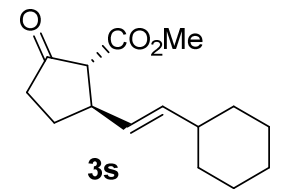

$54 \%$ yield, Colorless oil, $\mathrm{R}_{f}=0.2($ EtOAc/petroleum ether $=1: 20)$.

${ }^{1} \mathbf{H}$ NMR $\left(400 \mathrm{MHz}, \mathrm{CDCl}_{3}\right) \delta 5.51(\mathrm{dd}, J=15.5,6.6 \mathrm{~Hz}, 1 \mathrm{H}), 5.39-5.31(\mathrm{~m}, 1 \mathrm{H}), 3.74(\mathrm{~s}, 3 \mathrm{H}), 3.18$ $-3.06(\mathrm{~m}, 1 \mathrm{H}), 2.96(\mathrm{~d}, J=11.5 \mathrm{~Hz}, 1 \mathrm{H}), 2.44(\mathrm{dd}, J=18.7,8.4 \mathrm{~Hz}, 1 \mathrm{H}), 2.38-2.28(\mathrm{~m}, 1 \mathrm{H}), 2.24-$ $2.15(\mathrm{~m}, 1 \mathrm{H}), 1.97-1.85(\mathrm{~m}, 1 \mathrm{H}), 1.71-1.61(\mathrm{~m}, 6 \mathrm{H}), 1.31-1.17(\mathrm{~m}, 3 \mathrm{H}), 1.09-0.97(\mathrm{~m}, 2 \mathrm{H})$.

${ }^{13} \mathbf{C}$ NMR $\left(100 \mathrm{MHz}, \mathrm{CDCl}_{3}\right) \delta 211.4,169.4,138.2,127.1,61.5,52.4,44.2,40.5,38.2,32.9,32.8,27.8$, 26.1, 25.9.

HRMS (ESI) calcd. for $\mathrm{C}_{15} \mathrm{H}_{22} \mathrm{NaO}_{3}{ }^{+}(\mathrm{M}+\mathrm{Na})^{+}: 273.1461$, Found: 273.1458 . 


\section{Methyl (E)-2-oxo-5-(4-phenylbut-1-en-1-yl)cyclopentane-1-carboxylate (3t)}

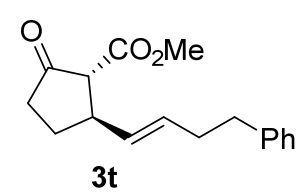

$58 \%$ yield, Colorless oil, $\mathrm{R}_{f}=0.3($ EtOAc/petroleum ether $=1: 10)$.

${ }^{1} \mathbf{H}$ NMR $\left(400 \mathrm{MHz}, \mathrm{CDCl}_{3}\right) \delta 7.32-7.22(\mathrm{~m}, 2 \mathrm{H}), 7.22-7.10(\mathrm{~m}, 3 \mathrm{H}), 5.65-5.55(\mathrm{~m}, 1 \mathrm{H}), 5.40(\mathrm{dd}$, $J=15.3,7.1 \mathrm{~Hz}, 1 \mathrm{H}), 3.75(\mathrm{~s}, 3 \mathrm{H}), 3.22-3.07(\mathrm{~m}, 1 \mathrm{H}), 2.94(\mathrm{~d}, J=11.5 \mathrm{~Hz}, 1 \mathrm{H}), 2.67(\mathrm{t}, J=7.6 \mathrm{~Hz}$, 2H), $2.43(\mathrm{dd}, J=19.0,8.3 \mathrm{~Hz}, 1 \mathrm{H}), 2.37-2.28(\mathrm{~m}, 3 \mathrm{H}), 2.18(\mathrm{dt}, J=14.5,7.4 \mathrm{~Hz}, 1 \mathrm{H}), 1.66-1.56$ $(\mathrm{m}, 1 \mathrm{H})$.

${ }^{13} \mathbf{C}$ NMR $\left(100 \mathrm{MHz}, \mathrm{CDCl}_{3}\right) \delta 211.1,169.2,141.6,131.2,130.7,128.5,128.2,125.8,61.3,52.4,44.0$, $38.2,35.7,34.2,27.7$.

HRMS (ESI) calcd. for $\mathrm{C}_{17} \mathrm{H}_{20} \mathrm{NaO}_{3}{ }^{+}(\mathrm{M}+\mathrm{Na})^{+}$: 295.1305, Found: 295.1301 .

\section{Methyl (E)-2-(4-acetoxybut-1-en-1-yl)-5-oxocyclopentane-1-carboxylate (3u)}

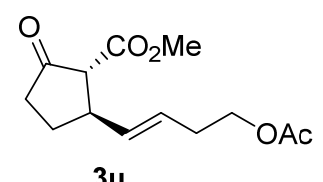

$61 \%$ yield, Colorless oil, $\mathrm{R}_{f}=0.2($ EtOAc/petroleum ether $=1: 6)$.

${ }^{1} \mathbf{H}$ NMR (400 MHz, $\left.\mathrm{CDCl}_{3}\right) \delta 5.59-5.47(\mathrm{~m}, 2 \mathrm{H}), 4.07(\mathrm{dd}, J=6.8,6.1 \mathrm{~Hz}, 2 \mathrm{H}), 3.75(\mathrm{~s}, 3 \mathrm{H}), 3.23-$ $3.12(\mathrm{~m}, 1 \mathrm{H}), 2.97$ (d, $J=11.6 \mathrm{~Hz}, 1 \mathrm{H}), 2.45(\mathrm{dd}, J=18.7,8.5 \mathrm{~Hz}, 1 \mathrm{H}), 2.40-2.29$ (m, 3H), $2.27-$ $2.16(\mathrm{~m}, 1 \mathrm{H}), 2.03(\mathrm{~s}, 3 \mathrm{H}), 1.72-1.62(\mathrm{~m}, 1 \mathrm{H})$.

${ }^{13} \mathrm{C}$ NMR $\left(100 \mathrm{MHz}, \mathrm{CDCl}_{3}\right) \delta 210.8,171.0,169.1,132.8,127.3,63.5,61.2,52.5,44.0,38.1,31.8$, 27.6, 20.9.

HRMS (ESI) calcd. for $\mathrm{C}_{13} \mathrm{H}_{18} \mathrm{NaO}_{5}^{+}(\mathrm{M}+\mathrm{Na})^{+}: 277.1046$, Found: 277.1044 .

\section{Methyl (E)-2-(4-((tert-butyldimethylsilyl)oxy)but-1-en-1-yl)-5-oxocyclopentane-1-carboxylate}

(3v)

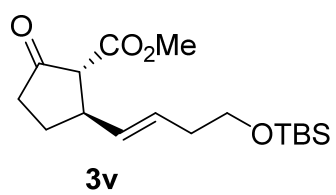

$61 \%$ yield, Colorless oil, $\mathrm{R}_{f}=0.4($ EtOAc/petroleum ether $=1: 25)$.

${ }^{1} \mathbf{H}$ NMR $\left(400 \mathrm{MHz}, \mathrm{CDCl}_{3}\right) \delta 5.63-5.53(\mathrm{~m}, 1 \mathrm{H}), 5.48(\mathrm{dd}, J=15.4,6.8 \mathrm{~Hz}, 1 \mathrm{H}), 3.74(\mathrm{~s}, 3 \mathrm{H}), 3.61$ $(\mathrm{t}, J=6.6 \mathrm{~Hz}, 2 \mathrm{H}), 3.23-3.11(\mathrm{~m}, 1 \mathrm{H}), 2.97(\mathrm{~d}, J=11.5 \mathrm{~Hz}, 1 \mathrm{H}), 2.44(\mathrm{dd}, J=18.7,8.5 \mathrm{~Hz}, 1 \mathrm{H}), 2.38$ $-2.27(\mathrm{~m}, 1 \mathrm{H}), 2.27-2.17(\mathrm{~m}, 3 \mathrm{H}), 1.72-1.58(\mathrm{~m}, 1 \mathrm{H}), 0.88(\mathrm{~s}, 9 \mathrm{H}), 0.03(\mathrm{~s}, 6 \mathrm{H})$.

${ }^{13} \mathrm{C}$ NMR $\left(100 \mathrm{MHz}, \mathrm{CDCl}_{3}\right) \delta 211.1,169.2,131.8,128.7,62.7,61.2,52.4,44.0,38.2,36.0,27.7,25.9$, $18.3,-5.3$.

HRMS (ESI) calcd. for $\mathrm{C}_{17} \mathrm{H}_{30} \mathrm{NaO}_{4} \mathrm{Si}^{+}(\mathrm{M}+\mathrm{Na})^{+}: 349.1806$, Found: 349.1803 . 


\section{General procedure for $(4+3)$ cycloaddition}

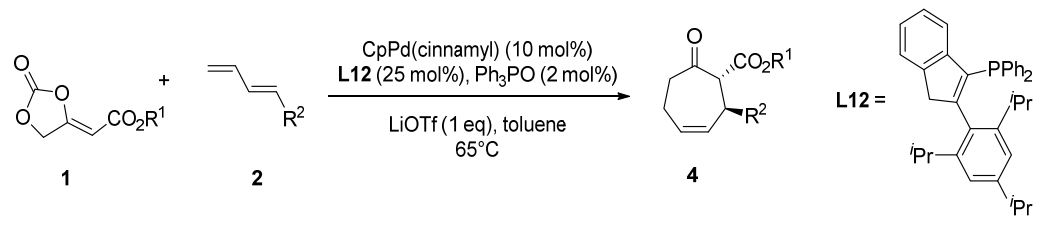

In a glovebox, CpPd(cinnamyl) $(2.9 \mathrm{mg}, 0.01 \mathrm{mmol})$ and $\mathbf{L 1 2}(12.5 \mathrm{mg}, 0.025 \mathrm{mmol}), \mathrm{Ph}_{3} \mathrm{PO}(0.6$ $\mathrm{mg}, 0.002 \mathrm{mmol})$ were dissolved in toluene $(3.5 \mathrm{~mL})$ in a sealing tube and the mixtures were stirred for $1 \mathrm{~h}$ at room temperature. Then the starting material $\mathbf{1}(0.1 \mathrm{mmol})$ and 1,3-diene $2(0.2$ mmol) were added, followed with LiOTf $(15.6 \mathrm{mg}, 0.1 \mathrm{mmol})$. The tube was then sealed and removed from the glovebox and placed in a preheated oil bath $\left(65^{\circ} \mathrm{C}\right)$ for $48 \mathrm{~h}$. The resulting mixture was concentrated under reduced pressure, and purified by column chromatography to give the corresponding $(4+3)$ cycloaddition product 4 .

\section{Methyl 7-oxo-2-phenylcyclohept-3-ene-1-carboxylate (4a)}<smiles>COC(=O)[C@H]1C(=O)CCC=C[C@H]1c1ccccc1</smiles>

$4 a$

$66 \%$ yield, Light yellow oil, $\mathrm{R}_{f}=0.2($ EtOAc/petroleum ether $=1: 10)$.

${ }^{1} \mathbf{H}$ NMR $\left(400 \mathrm{MHz}, \mathrm{CDCl}_{3}\right) \delta 7.34-7.27(\mathrm{~m}, 4 \mathrm{H}), 7.22(\mathrm{t}, J=6.9 \mathrm{~Hz}, 1 \mathrm{H}), 5.85(\mathrm{dt}, J=11.4,5.7 \mathrm{~Hz}$, $1 \mathrm{H}), 5.66(\mathrm{~d}, J=12.1 \mathrm{~Hz}, 1 \mathrm{H}), 4.30-4.18(\mathrm{~m}, 2 \mathrm{H}), 3.54(\mathrm{~s}, 3 \mathrm{H}), 3.06-2.94(\mathrm{~m}, 1 \mathrm{H}), 2.78-2.63(\mathrm{~m}$, $2 \mathrm{H}), 2.49-2.36(\mathrm{~m}, 1 \mathrm{H})$.

${ }^{13}$ C NMR $\left(100 \mathrm{MHz} \mathrm{CDCl}_{3}\right) \delta 205.6,168.8,141.7,132.8,128.7,128.4,128.0,127.1,64.2,52.1,45.3$, 42.7, 23.3.

HRMS (ESI) calcd. for $\mathrm{C}_{15} \mathrm{H}_{16} \mathrm{NaO}_{3}{ }^{+}(\mathrm{M}+\mathrm{Na})^{+}: 267.0992$, Found: 267.0990 .

Ethyl 7-oxo-2-phenylcyclohept-3-ene-1-carboxylate (4b)<smiles>CCOC(=O)[C@H]1C(=O)CCC=C[C@H]1c1ccccc1</smiles>

4b

$62 \%$ yield, Light yellow oil, $\mathrm{R}_{f}=0.2($ EtOAc/petroleum ether $=1: 10)$.

${ }^{1} \mathbf{H}$ NMR $\left(400 \mathrm{MHz}, \mathrm{CDCl}_{3}\right) \delta 7.33-7.26(\mathrm{~m}, 4 \mathrm{H}), 7.25-7.20(\mathrm{~m}, 1 \mathrm{H}), 5.89-5.81(\mathrm{~m}, 1 \mathrm{H}), 5.67(\mathrm{~d}$, $J=11.5 \mathrm{~Hz}, 1 \mathrm{H}), 4.22(\mathrm{~s}, 2 \mathrm{H}), 4.00$ (q, $J=7.1 \mathrm{~Hz}, 2 \mathrm{H}), 3.11-2.96(\mathrm{~m}, 1 \mathrm{H}), 2.78-2.62(\mathrm{~m}, 2 \mathrm{H}), 2.51$ $-2.37(\mathrm{~m}, 1 \mathrm{H}), 1.05(\mathrm{t}, J=7.1 \mathrm{~Hz}, 3 \mathrm{H})$.

${ }^{13}$ C NMR $\left(100 \mathrm{MHz}, \mathrm{CDCl}_{3}\right) \delta 205.9,168.4,141.7,132.9,128.7,128.4,128.1,127.1,64.3,61.1,45.2$, $42.6,23.4,13.8$.

HRMS (ESI) calcd. for $\mathrm{C}_{16} \mathrm{H}_{18} \mathrm{NaO}_{3}{ }^{+}(\mathrm{M}+\mathrm{Na})^{+}: 281.1148$, Found: 281.1146 .

Methyl 2-(4-fluorophenyl)-7-oxocyclohept-3-ene-1-carboxylate (4c) 


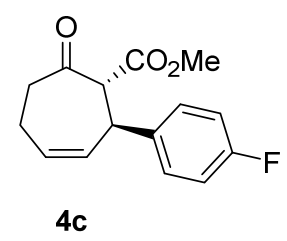

$72 \%$ yield, Light yellow oil, $\mathrm{R}_{f}=0.1($ EtOAc/petroleum ether $=1: 10)$.

${ }^{1} \mathbf{H}$ NMR (400 MHz, $\left.\mathrm{CDCl}_{3}\right) \delta 7.26-7.19(\mathrm{~m}, 2 \mathrm{H}), 6.99(\mathrm{t}, J=8.6 \mathrm{~Hz}, 2 \mathrm{H}), 5.86(\mathrm{dt}, J=11.4,5.7 \mathrm{~Hz}$, $1 \mathrm{H}), 5.62(\mathrm{~d}, J=11.6 \mathrm{~Hz}, 1 \mathrm{H}), 4.24-4.11(\mathrm{~m}, 2 \mathrm{H}), 3.56(\mathrm{~s}, 3 \mathrm{H}), 3.04-2.93(\mathrm{~m}, 1 \mathrm{H}), 2.78-2.61(\mathrm{~m}$, $2 \mathrm{H}), 2.47-2.34(\mathrm{~m}, 1 \mathrm{H})$.

${ }^{13}$ C NMR (100 MHz, CDCl 3$) \delta 205.3,168.8,161.8(\mathrm{~d}, J=245.9 \mathrm{~Hz}), 137.4(\mathrm{~d}, J=3.0 \mathrm{~Hz}), 132.6$, $129.7(\mathrm{~d}, J=7.9 \mathrm{~Hz}), 128.6,115.6(\mathrm{~d}, J=21.5 \mathrm{~Hz}), 64.2,52.2,44.6,42.7,23.2$.

${ }^{19}$ F NMR $\left(376 \mathrm{MHz}, \mathrm{CDCl}_{3}\right) \delta-119.6$.

HRMS (ESI) calcd. for $\mathrm{C}_{15} \mathrm{H}_{15} \mathrm{FNaO}_{3}{ }^{+}(\mathrm{M}+\mathrm{Na})^{+}: 285.0897$, Found: 285.0896

\section{Methyl 7-oxo-2-(4-(trifluoromethyl)phenyl)cyclohept-3-ene-1-carboxylate (4d)}

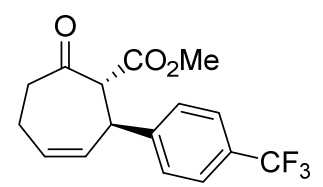

4d

$50 \%$ yield, Colorless oil, $\mathrm{R}_{f}=0.2($ EtOAc/petroleum ether $=1: 10)$.

${ }^{1} \mathbf{H}$ NMR $\left(400 \mathrm{MHz}, \mathrm{CDCl}_{3}\right) \delta 7.57(\mathrm{~d}, J=8.2 \mathrm{~Hz}, 2 \mathrm{H}), 7.41(\mathrm{~d}, J=8.1 \mathrm{~Hz}, 2 \mathrm{H}), 5.97-5.84(\mathrm{~m}, 1 \mathrm{H})$, $5.66-5.55(\mathrm{~m}, 1 \mathrm{H}), 4.36-4.22(\mathrm{~m}, 2 \mathrm{H}), 3.57(\mathrm{~s}, 3 \mathrm{H}), 3.09-2.93(\mathrm{~m}, 1 \mathrm{H}), 2.80-2.65(\mathrm{~m}, 2 \mathrm{H}), 2.45$ (ddd, $J=18.0,9.8,5.4 \mathrm{~Hz}, 1 \mathrm{H}$ ).

${ }^{13}$ C NMR (100 MHz, CDCl 3$) \delta 205.0,168.6,145.8,131.9,129.5$ (q, $\left.J=32.3 \mathrm{~Hz}\right), 129.2,128.5,125.7$ $(\mathrm{q}, J=3.8 \mathrm{~Hz}), 124.0(\mathrm{q}, J=272.2 \mathrm{~Hz}), 63.6,52.3,45.0,42.7,23.1$.

${ }^{19} \mathbf{F}$ NMR $\left(376 \mathrm{MHz}, \mathrm{CDCl}_{3}\right) \delta-66.8$.

HRMS (ESI) calcd. for $\mathrm{C}_{15} \mathrm{H}_{15} \mathrm{~F}_{3} \mathrm{NaO}_{3}{ }^{+}(\mathrm{M}+\mathrm{Na})^{+}: 335.0866$, Found: 335.0864 .

Methyl 7-oxo-2-(p-tolyl)cyclohept-3-ene-1-carboxylate (4e)

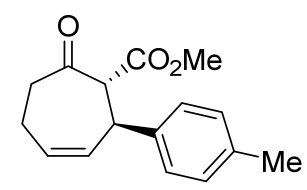

$4 e$

$55 \%$ yield, Light yellow oil, $\mathrm{R}_{f}=0.2($ EtOAc/petroleum ether $=1: 10)$.

${ }^{1} \mathbf{H}$ NMR $\left(400 \mathrm{MHz}, \mathrm{CDCl}_{3}\right) \delta 7.16(\mathrm{~d}, J=6.3 \mathrm{~Hz}, 2 \mathrm{H}), 7.10(\mathrm{~d}, J=6.9 \mathrm{~Hz}, 2 \mathrm{H}), 5.89-5.79(\mathrm{~m}, 1 \mathrm{H})$, $5.68-5.60(\mathrm{~m}, 1 \mathrm{H}), 4.29-4.13(\mathrm{~m}, 2 \mathrm{H}), 3.56(\mathrm{~s}, 3 \mathrm{H}), 3.07-2.92(\mathrm{~m}, 1 \mathrm{H}), 2.80-2.61(\mathrm{~m}, 2 \mathrm{H}), 2.50-$ $2.35(\mathrm{~m}, 1 \mathrm{H}), 2.31(\mathrm{~s}, 3 \mathrm{H})$.

${ }^{13} \mathbf{C}$ NMR $\left(100 \mathrm{MHz}, \mathrm{CDCl}_{3}\right) \delta 205.8,168.9,138.6,136.8,133.0,129.4,128.1,127.9,64.1,52.1,44.9$, $42.8,23.2,21.0$.

HRMS (ESI) calcd. for $\mathrm{C}_{16} \mathrm{H}_{18} \mathrm{NaO}_{3}{ }^{+}(\mathrm{M}+\mathrm{Na})^{+}: 281.1148$, Found: 281.1146 .

Methyl 7-oxo-2-(m-tolyl)cyclohept-3-ene-1-carboxylate (4f) 


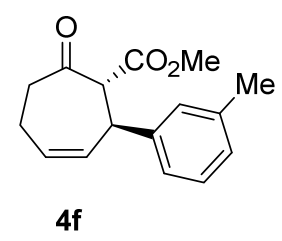

$45 \%$ yield, Light yellow oil, $\mathrm{R}_{f}=0.2($ EtOAc/petroleum ether $=1: 10)$.

${ }^{1} \mathbf{H}$ NMR $\left(400 \mathrm{MHz}, \mathrm{CDCl}_{3}\right) \delta 7.19(\mathrm{t}, J=7.8 \mathrm{~Hz}, 1 \mathrm{H}), 7.09-7.02$ (m, 3H), 5.84 (ddd, $J=11.6,6.4$, $1.5 \mathrm{~Hz}, 1 \mathrm{H}), 5.65(\mathrm{dd}, J=11.8,4.0 \mathrm{~Hz}, 1 \mathrm{H}), 4.25(\mathrm{~d}, J=10.7 \mathrm{~Hz}, 1 \mathrm{H}), 4.18(\mathrm{~d}, J=13.2 \mathrm{~Hz}, 1 \mathrm{H}), 3.56$ (s, 3H), $3.05-2.94(\mathrm{~m}, 1 \mathrm{H}), 2.79-2.62(\mathrm{~m}, 2 \mathrm{H}), 2.47-2.38(\mathrm{~m}, 1 \mathrm{H}), 2.33(\mathrm{~s}, 3 \mathrm{H})$.

${ }^{13} \mathbf{C}$ NMR $\left(100 \mathrm{MHz}, \mathrm{CDCl}_{3}\right) \delta 205.7,168.9,141.6,138.3,132.9,128.7,128.6,128.2,127.9,125.1$, 64.1, 52.1, 45.2, 42.7, 23.2, 21.4.

HRMS (ESI) calcd. for $\mathrm{C}_{16} \mathrm{H}_{18} \mathrm{NaO}_{3}{ }^{+}(\mathrm{M}+\mathrm{Na})^{+}: 281.1148$, Found: 281.1146.

Methyl 2-(3-fluorophenyl)-7-oxocyclohept-3-ene-1-carboxylate (4g)

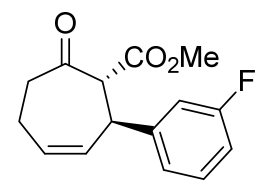

$4 \mathrm{~g}$

$55 \%$ yield, Light yellow oil, $\mathrm{R}_{f}=0.3($ EtOAc/petroleum ether $=1: 10)$.

${ }^{1} \mathbf{H}$ NMR (400 MHz, $\left.\mathrm{CDCl}_{3}\right) \delta 7.32-7.23(\mathrm{~m}, 1 \mathrm{H}), 7.06(\mathrm{~d}, J=7.7 \mathrm{~Hz}, 1 \mathrm{H}), 7.02-6.96(\mathrm{~m}, 1 \mathrm{H}), 6.93$ $(\mathrm{td}, J=8.4,2.3 \mathrm{~Hz}, 1 \mathrm{H}), 5.88(\mathrm{dt}, J=11.4,5.5 \mathrm{~Hz}, 1 \mathrm{H}), 5.63(\mathrm{~d}, J=11.1 \mathrm{~Hz}, 1 \mathrm{H}), 4.22(\mathrm{~s}, 2 \mathrm{H}), 3.57$ (s, $3 \mathrm{H}), 3.05-2.93(\mathrm{~m}, 1 \mathrm{H}), 2.70(\mathrm{ddt}, J=20.1,15.3,4.6 \mathrm{~Hz}, 2 \mathrm{H}), 2.49-2.36(\mathrm{~m}, 1 \mathrm{H})$.

${ }^{13}$ C NMR $\left(100 \mathrm{MHz}, \mathrm{CDCl}_{3}\right) \delta 205.2,168.7,162.9(\mathrm{~d}, J=246.3 \mathrm{~Hz}), 144.2(\mathrm{~d}, J=6.9 \mathrm{~Hz}), 132.1$, $130.2(\mathrm{~d}, J=8.2 \mathrm{~Hz}), 129.0,123.8(\mathrm{~d}, J=2.9 \mathrm{~Hz}), 115.0(\mathrm{~d}, J=21.7 \mathrm{~Hz}), 114.2(\mathrm{~d}, J=21.1 \mathrm{~Hz}), 63.8$, $52.3,44.9,42.7,23.1$.

${ }^{19}$ F NMR (376 MHz, DMSO) $\delta-116.7$.

HRMS (ESI) calcd. for $\mathrm{C}_{15} \mathrm{H}_{15} \mathrm{FNaO}_{3}{ }^{+}(\mathrm{M}+\mathrm{Na})^{+}:$285.0897, Found: 285.0896 .

Methyl 2-(2-fluorophenyl)-7-oxocyclohept-3-ene-1-carboxylate (4h)

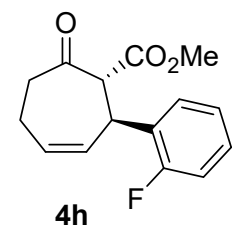

$40 \%$ yield, Light yellow oil, $\mathrm{R}_{f}=0.3($ EtOAc/petroleum ether $=1: 10)$.

${ }^{1}$ H NMR (400 MHz, $\left.\mathrm{CDCl}_{3}\right) \delta 7.31-7.19(\mathrm{~m}, 2 \mathrm{H}), 7.13-6.98(\mathrm{~m}, 2 \mathrm{H}), 5.92-5.80(\mathrm{~m}, 1 \mathrm{H}), 5.61(\mathrm{dd}$, $J=11.3,3.9 \mathrm{~Hz}, 1 \mathrm{H}), 4.49-4.42(\mathrm{~m}, 1 \mathrm{H}), 4.38(\mathrm{~d}, J=10.6 \mathrm{~Hz}, 1 \mathrm{H}), 3.56(\mathrm{~s}, 3 \mathrm{H}), 3.11-2.95(\mathrm{~m}, 1 \mathrm{H})$, $2.77-2.60(\mathrm{~m}, 2 \mathrm{H}), 2.51-2.37(\mathrm{~m}, 1 \mathrm{H})$.

${ }^{13}$ C NMR (100 MHz, CDCl $) \delta 205.6,168.8,160.7(\mathrm{~d}, J=247.3 \mathrm{~Hz}), 131.2,130.2(\mathrm{~d}, J=4.3 \mathrm{~Hz})$, $129.0(\mathrm{~d}, J=8.3 \mathrm{~Hz}), 128.9,128.3$ (d, $J=13.3 \mathrm{~Hz}), 124.4$ (d, $J=3.3 \mathrm{~Hz}), 115.9$ (d, $J=22.3 \mathrm{~Hz}), 62.3$, $52.2,42.4,39.8,23.3$.

${ }^{19}$ F NMR $\left(376 \mathrm{MHz}, \mathrm{CDCl}_{3}\right) \delta-120.8$.

HRMS (ESI) calcd. for $\mathrm{C}_{15} \mathrm{H}_{15} \mathrm{FNaO}_{3}^{+}(\mathrm{M}+\mathrm{Na})^{+}: 285.0897$, Found: 285.0896 . 


\section{Methyl 7-oxo-2-(o-tolyl)cyclohept-3-ene-1-carboxylate (4i)}

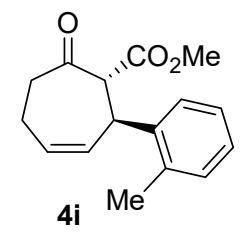

$55 \%$ yield, Light yellow oil, $\mathrm{R}_{f}=0.2($ EtOAc/petroleum ether $=1: 10)$.

${ }^{1} \mathbf{H}$ NMR (400 MHz, $\left.\mathrm{CDCl}_{3}\right) \delta 7.23-7.08(\mathrm{~m}, 4 \mathrm{H}), 5.80$ (ddd, $\left.J=11.3,6.7,2.0 \mathrm{~Hz}, 1 \mathrm{H}\right), 5.54(\mathrm{dd}, J=$ $11.4,3.9 \mathrm{~Hz}, 1 \mathrm{H}), 4.49-4.42(\mathrm{~m}, 1 \mathrm{H}), 4.38(\mathrm{~d}, J=10.9 \mathrm{~Hz}, 1 \mathrm{H}), 3.51(\mathrm{~s}, 3 \mathrm{H}), 3.14-2.97(\mathrm{~m}, 1 \mathrm{H})$, $2.79-2.66(\mathrm{~m}, 2 \mathrm{H}), 2.49-2.37(\mathrm{~m}, 4 \mathrm{H})$.

${ }^{13} \mathbf{C}$ NMR $\left(100 \mathrm{MHz}, \mathrm{CDCl}_{3}\right) \delta 206.2,168.9,140.2,135.9,132.9,130.8,127.8,127.1,126.9,126.5$, 63.2, 52.1, 42.5, 40.8, 23.3, 19.6 .

HRMS (ESI) calcd. for $\mathrm{C}_{16} \mathrm{H}_{18} \mathrm{NaO}_{3}{ }^{+}(\mathrm{M}+\mathrm{Na})^{+}: 281.1148$, Found: 281.1147.

Methyl 2-(naphthalen-2-yl)-7-oxocyclohept-3-ene-1-carboxylate (4j)

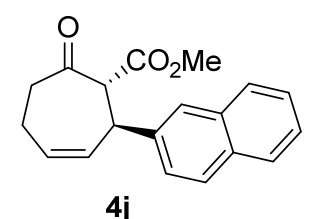

$64 \%$ yield, White solid, $\mathrm{R}_{f}=0.3$ (EtOAc/petroleum ether $\left.=1: 10\right)$, m.p. $98.7-99.4^{\circ} \mathrm{C}$.

${ }^{1} \mathbf{H}$ NMR $\left(400 \mathrm{MHz}, \mathrm{CDCl}_{3}\right) \delta 7.85-7.77(\mathrm{~m}, 3 \mathrm{H}), 7.73(\mathrm{~s}, 1 \mathrm{H}), 7.49-7.44(\mathrm{~m}, 2 \mathrm{H}), 7.41(\mathrm{dd}, J=8.5$, $1.7 \mathrm{~Hz}, 1 \mathrm{H}), 5.91(\mathrm{dt}, J=11.3,5.6 \mathrm{~Hz}, 1 \mathrm{H}), 5.76-5.69(\mathrm{~m}, 1 \mathrm{H}), 4.46-4.34(\mathrm{~m}, 2 \mathrm{H}), 3.52(\mathrm{~s}, 3 \mathrm{H})$, $3.11-2.97(\mathrm{~m}, 1 \mathrm{H}), 2.86-2.66(\mathrm{~m}, 2 \mathrm{H}), 2.56-2.41(\mathrm{~m}, 1 \mathrm{H})$.

${ }^{13}$ C NMR $\left(100 \mathrm{MHz}, \mathrm{CDCl}_{3}\right) \delta 205.6,168.9,139.0,133.4,132.7,132.5,128.6,128.6,127.8,127.6$, $127.0,126.2,125.9,125.9,64.0,52.2,45.4,42.8,23.3$.

HRMS (ESI) calcd. for $\mathrm{C}_{19} \mathrm{H}_{18} \mathrm{NaO}_{3}{ }^{+}(\mathrm{M}+\mathrm{Na})^{+}: 317.1148$, Found: 317.1145 .

Methyl 2-(naphthalen-1-yl)-7-oxocyclohept-3-ene-1-carboxylate (4k)

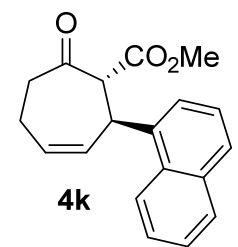

$61 \%$ yield, Light yellow solid, $\mathrm{R}_{f}=0.3$ (EtOAc/petroleum ether $\left.=1: 10\right)$, m.p. $92.2-92.9^{\circ} \mathrm{C}$.

${ }^{1} \mathbf{H}$ NMR $\left(400 \mathrm{MHz}, \mathrm{CDCl}_{3}\right) \delta 8.14(\mathrm{~d}, J=8.5 \mathrm{~Hz}, 1 \mathrm{H}), 7.87(\mathrm{~d}, J=7.6 \mathrm{~Hz}, 1 \mathrm{H}), 7.76(\mathrm{dd}, J=7.3,1.8$ $\mathrm{Hz}, 1 \mathrm{H}), 7.58-7.46(\mathrm{~m}, 2 \mathrm{H}), 7.46-7.39(\mathrm{~m}, 2 \mathrm{H}), 5.91-5.83(\mathrm{~m}, 1 \mathrm{H}), 5.79-5.69(\mathrm{~m}, 1 \mathrm{H}), 5.14-$ $5.07(\mathrm{~m}, 1 \mathrm{H}), 4.46(\mathrm{~d}, J=9.7 \mathrm{~Hz}, 1 \mathrm{H}), 3.49(\mathrm{~s}, 3 \mathrm{H}), 3.21-3.07(\mathrm{~m}, 1 \mathrm{H}), 2.80-2.64(\mathrm{~m}, 2 \mathrm{H}), 2.60-$ $2.49(\mathrm{~m}, 1 \mathrm{H})$.

${ }^{13}$ C NMR $\left(100 \mathrm{MHz}, \mathrm{CDCl}_{3}\right) \delta 205.8,169.0,137.6,134.2,132.6,130.9,129.1,128.3,128.0,126.3$, $125.7,125.5,125.4,123.3,64.0,52.2,41.8,40.6,23.9$.

HRMS (ESI) calcd. for $\mathrm{C}_{19} \mathrm{H}_{18} \mathrm{NaO}_{3}{ }^{+}(\mathrm{M}+\mathrm{Na})^{+}: 317.1148$, Found: 317.1145 . 
Methyl 2-(furan-2-yl)-7-oxocyclohept-3-ene-1-carboxylate (4I)

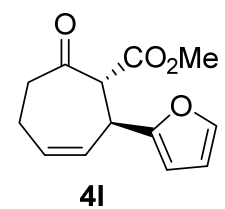

$40 \%$ yield, yellow oil, $\mathrm{R}_{f}=0.3($ EtOAc/petroleum ether $=1: 10)$.

${ }^{1} \mathbf{H}$ NMR $\left(400 \mathrm{MHz}, \mathrm{CDCl}_{3}\right) \delta 7.33(\mathrm{~s}, 1 \mathrm{H}), 6.27(\mathrm{~s}, 1 \mathrm{H}), 6.11(\mathrm{~s}, 1 \mathrm{H}), 5.88(\mathrm{dt}, J=11.2,5.5 \mathrm{~Hz}, 1 \mathrm{H})$, $5.75(\mathrm{dd}, J=11.4,5.3 \mathrm{~Hz}, 1 \mathrm{H}), 4.43-4.36$ (m, 1H), 4.19 (d, $J=8.8 \mathrm{~Hz}, 1 \mathrm{H}), 3.69$ (s, 3H), $2.95-2.86$ $(\mathrm{m}, 1 \mathrm{H}), 2.71-2.61(\mathrm{~m}, 1 \mathrm{H}), 2.60-2.49(\mathrm{~m}, 1 \mathrm{H}), 2.48-2.38(\mathrm{~m}, 1 \mathrm{H})$.

${ }^{13}$ C NMR $\left(100 \mathrm{MHz}, \mathrm{CDCl}_{3}\right) \delta 205.2,169.0,153.7,142.2,130.1,128.9,110.3,106.6,62.0,52.5,42.1$, $38.2,23.4$.

HRMS (ESI) calcd. for $\mathrm{C}_{13} \mathrm{H}_{14} \mathrm{NaO}_{4}^{+}(\mathrm{M}+\mathrm{Na})^{+}:$257.0784, Found: 257.0783 .

Methyl 7-oxo-2-(thiophen-2-yl)cyclohept-3-ene-1-carboxylate (4m)

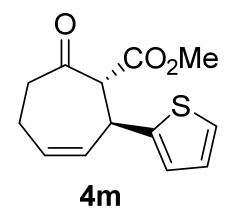

$47 \%$ yield, Light yellow oil, $\mathrm{R}_{f}=0.3($ EtOAc/petroleum ether $=1: 10)$.

${ }^{1} \mathbf{H}$ NMR $\left(400 \mathrm{MHz}, \mathrm{CDCl}_{3}\right) \delta 7.18(\mathrm{dd}, J=4.1,2.2 \mathrm{~Hz}, 1 \mathrm{H}), 6.94-6.88(\mathrm{~m}, 2 \mathrm{H}), 5.94-5.83(\mathrm{~m}, 1 \mathrm{H})$, $5.82-5.75(\mathrm{~m}, 1 \mathrm{H}), 4.61-4.53(\mathrm{~m}, 1 \mathrm{H}), 4.23(\mathrm{~d}, J=9.7 \mathrm{~Hz}, 1 \mathrm{H}), 3.66(\mathrm{~s}, 3 \mathrm{H}), 2.95-2.85(\mathrm{~m}, 1 \mathrm{H})$, $2.77-2.59(\mathrm{~m}, 2 \mathrm{H}), 2.44-2.35(\mathrm{~m}, 1 \mathrm{H})$.

${ }^{13} \mathrm{C}$ NMR $\left(100 \mathrm{MHz}, \mathrm{CDCl}_{3}\right) \delta 205.0,168.8,144.8,131.8,129.2,126.9,125.3,124.6,64.6,52.4,42.7$, 40.0, 23.0.

HRMS (ESI) calcd. for $\mathrm{C}_{13} \mathrm{H}_{14} \mathrm{NaO}_{3} \mathrm{~S}^{+}(\mathrm{M}+\mathrm{Na})^{+}:$273.0556, Found: 273.0555 .

Methyl 7-oxo-2-(1-tosyl-1H-indol-3-yl)cyclohept-3-ene-1-carboxylate (4n)<smiles></smiles>

$60 \%$ yield, Light yellow solid, $\mathrm{R}_{f}=0.3$ (EtOAc/petroleum ether $\left.=1: 6\right)$, m.p. $62.3-62.9^{\circ} \mathrm{C}$.

${ }^{1} \mathbf{H}$ NMR $\left(400 \mathrm{MHz}, \mathrm{CDCl}_{3}\right) \delta 7.96(\mathrm{~d}, J=8.2 \mathrm{~Hz}, 1 \mathrm{H}), 7.71(\mathrm{dd}, J=8.3,3.8 \mathrm{~Hz}, 2 \mathrm{H}), 7.54(\mathrm{~d}, J=7.8$ $\mathrm{Hz}, 1 \mathrm{H}), 7.44$ (s, 1H), $7.35-7.28(\mathrm{~m}, 1 \mathrm{H}), 7.22$ (dt, $J=15.7,7.8 \mathrm{~Hz}, 3 \mathrm{H}), 5.87$ (dtd, $J=7.0,5.3,1.6$ $\mathrm{Hz}, 1 \mathrm{H}), 5.72(\mathrm{dd}, J=11.4,4.7 \mathrm{~Hz}, 1 \mathrm{H}), 4.55-4.47(\mathrm{~m}, 1 \mathrm{H}), 4.23(\mathrm{~d}, J=9.8 \mathrm{~Hz}, 1 \mathrm{H}), 3.50(\mathrm{~s}, 3 \mathrm{H})$, $3.06(\mathrm{ddd}, J=16.0,10.6,5.1 \mathrm{~Hz}, 1 \mathrm{H}), 2.71-2.55(\mathrm{~m}, 2 \mathrm{H}), 2.55-2.45(\mathrm{~m}, 1 \mathrm{H}), 2.33(\mathrm{~s}, 3 \mathrm{H})$.

${ }^{13} \mathbf{C}$ NMR $\left(100 \mathrm{MHz}, \mathrm{CDCl}_{3}\right) \delta 205.2,168.7,144.9,135.4,135.1,130.8,129.8,129.4,129.0,126.7$, $125.0,124.1,123.2,122.6,119.8,113.9,63.1,52.2,41.7,36.0,23.9,21.5$.

HRMS (ESI) calcd. for $\mathrm{C}_{24} \mathrm{H}_{23} \mathrm{NNaO}_{5} \mathrm{~S}^{+}(\mathrm{M}+\mathrm{Na})^{+}: 460.1189$, Found: 460.1185 .

Methyl 2-(2-((tert-butyldimethylsilyl)oxy)ethyl)-7-oxocyclohept-3-ene-1-carboxylate (4o) 


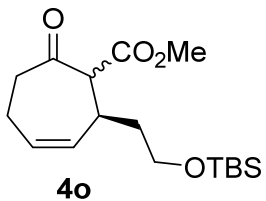

$45 \%$ yield, $\mathrm{dr}=2.2: 1$, Colorless oil, $\mathrm{R}_{f}=0.4($ EtOAc/petroleum ether $=1: 25)$.

${ }^{1} \mathbf{H}$ NMR $\left(400 \mathrm{MHz}, \mathrm{CDCl}_{3}\right) \delta 5.92-5.48(\mathrm{~m}, 2 \mathrm{H}), 3.95-3.57(\mathrm{~m}, 6 \mathrm{H}), 3.26-3.14(\mathrm{~m}, 0.69 \mathrm{H}), 2.99$ $-2.86(\mathrm{~m}, 1 \mathrm{H}), 2.82-2.70(\mathrm{~m}, 0.31 \mathrm{H}), 2.58-2.48(\mathrm{~m}, 1 \mathrm{H}), 2.45-2.27(\mathrm{~m}, 2 \mathrm{H}), 1.69-1.57(\mathrm{~m}, 2 \mathrm{H})$, $0.88(\mathrm{~s}, 6.20 \mathrm{H}), 0.87(\mathrm{~s}, 3 \mathrm{H}), 0.03(\mathrm{~s}, 6 \mathrm{H})$.

${ }^{13} \mathrm{C}$ NMR $\left(100 \mathrm{MHz}, \mathrm{CDCl}_{3}\right) \delta$ 206.8, 206.5, 169.7, 133.8, 132.5, 129.0, 63.1, 62.9, 60.8, 60.4, 52.3, $51.9,42.0,41.3,36.7,35.2,33.2,25.9,24.4,23.4,18.2,-5.4$

HRMS (ESI) calcd. for $\mathrm{C}_{17} \mathrm{H}_{30} \mathrm{NaO}_{4} \mathrm{Si}^{+}(\mathrm{M}+\mathrm{Na})^{+}: 349.1806$, Found: 349.1803 .

\section{Preparation of compound 5}

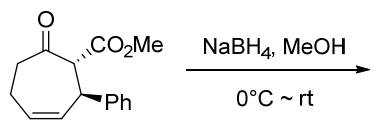

4a

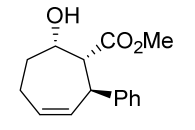

$5 a$

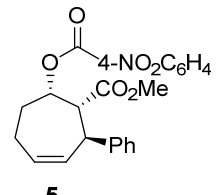

5

To a solution of $4 \mathbf{a}(49 \mathrm{mg}, 0.2 \mathrm{mmol})$ in $\mathrm{MeOH}(2 \mathrm{ml}), \mathrm{NaBH}_{4}(30 \mathrm{mg}, 0.8 \mathrm{mmol})$ was added at $0^{\circ} \mathrm{C}$ and the mixtures were gradually warmed to room temperature and stirred for additional $1 \mathrm{~h}$. The reaction was quenched with $\mathrm{H}_{2} \mathrm{O}$ and extracted with EtOAc. The combined organic layer was dried over $\mathrm{MgSO}_{4}$, and filtered. The filtrate was concentrated under reduced pressure to give a residue, which was purified by column chromatography using EtOAc/petroleum ether to give a white solid 5a (22 mg, 45\% yield). To a solution of $\mathbf{5 a}(25 \mathrm{mg}, 0.1 \mathrm{mmol})$ in THF (2 ml), 4-nitrobenzoyl chloride (19 $\mathrm{mg}, 0.105 \mathrm{mmol})$, DMAP (1.2 $\mathrm{mg}, 0.01 \mathrm{mmol}), \mathrm{NEt}_{3}(0.015 \mathrm{~mL}, 0.105 \mathrm{mmol})$ was added successively at $0{ }^{\circ} \mathrm{C}$. Then the mixture was allowed to warm to room temperature and stirred for additional $3 \mathrm{~h}$. The reaction was then quenched with saturated $\mathrm{NH}_{4} \mathrm{Cl}$ solution, extracted with ethyl acetate. The combined organic layer was dried over $\mathrm{MgSO}_{4}$, and filtered. The filtrate was concentrated under reduced pressure to give a residue, which was purified by column chromatography using EtOAc/petroleum ether to give a white solid ( $9.8 \mathrm{mg}, 36 \%$ yield). A single crystal was obtained by slowly evaporation a solution of 5 in $\mathrm{Et}_{2} \mathrm{O} /{ }^{n}$ hexane.

\section{Methyl 7-hydroxy-2-phenylcyclohept-3-ene-1-carboxylate (5a)}

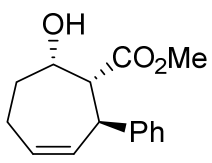

$5 \mathbf{a}$

$45 \%$ yield, White solid, $\mathrm{R}_{f}=0.5($ EtOAc/petroleum ether $=1: 6)$, m.p. $104.8-105.9^{\circ} \mathrm{C}$.

${ }^{1} \mathbf{H}$ NMR $\left(400 \mathrm{MHz}, \mathrm{CDCl}_{3}\right) \delta 7.30-7.24(\mathrm{~m}, 2 \mathrm{H}), 7.24-7.16(\mathrm{~m}, 3 \mathrm{H}), 5.96-5.84(\mathrm{~m}, 1 \mathrm{H}), 5.75$ (ddd, $J=11.2,4.1,2.1 \mathrm{~Hz}, 1 \mathrm{H}), 4.26$ (s, 2H), 3.79 (s, 1H), $3.22(\mathrm{~s}, 3 \mathrm{H}), 2.97$ (dd, $J=10.2,1.6 \mathrm{~Hz}, 1 \mathrm{H})$, $2.73-2.58(\mathrm{~m}, 1 \mathrm{H}), 2.09-1.94(\mathrm{~m}, 2 \mathrm{H}), 1.77-1.63(\mathrm{~m}, 1 \mathrm{H})$. 
${ }^{13} \mathrm{C}$ NMR $\left(100 \mathrm{MHz}, \mathrm{CDCl}_{3}\right) \delta 175.5,143.1,135.6,132.5,128.4,128.2,126.6,69.3,55.0,51.3,41.6$, 32.1, 21.4.

HRMS (ESI) calcd. for $\mathrm{C}_{15} \mathrm{H}_{18} \mathrm{NaO}_{3}{ }^{+}(\mathrm{M}+\mathrm{Na})^{+}: 269.1148$, Found: 269.1146 .

Methyl 7-((4-nitrobenzoyl)oxy)-2-phenylcyclohept-3-ene-1-carboxylate (5)

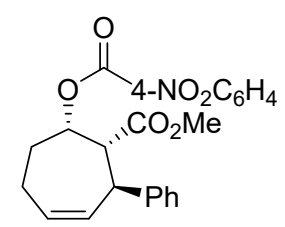

5

$36 \%$ yield, White solid, $\mathrm{R}_{f}=0.4($ EtOAc/petroleum ether $=1: 8)$, m.p. $93.6-94.2^{\circ} \mathrm{C}$.

${ }^{1} \mathbf{H}$ NMR $\left(400 \mathrm{MHz}, \mathrm{CDCl}_{3}\right) \delta 8.32(\mathrm{~d}, J=8.6 \mathrm{~Hz}, 2 \mathrm{H}), 8.25(\mathrm{~d}, J=8.7 \mathrm{~Hz}, 2 \mathrm{H}), 7.36-7.18(\mathrm{~m}, 5 \mathrm{H})$, $5.88(\mathrm{ddd}, J=10.9,7.7,3.2 \mathrm{~Hz}, 1 \mathrm{H}), 5.78-5.64(\mathrm{~m}, 2 \mathrm{H}), 4.28(\mathrm{~d}, J=10.2 \mathrm{~Hz}, 1 \mathrm{H}), 3.41-3.24(\mathrm{~m}$, 4H), $2.60-2.47$ (m, 1H), 2.40 (ddd, $J=11.2,9.6,5.5 \mathrm{~Hz}, 1 \mathrm{H}), 2.30$ (ddd, $J=17.7,11.0,6.8 \mathrm{~Hz}, 1 \mathrm{H}$ ), 1.98 (ddd, $J=13.0,8.4,4.2 \mathrm{~Hz}, 1 \mathrm{H})$.

${ }^{13} \mathrm{C}$ NMR $\left(100 \mathrm{MHz}, \mathrm{CDCl}_{3}\right) \delta 172.0,163.8,150.5,143.2,135.7,134.2,130.7,130.5,128.6,127.9$, 126.8, 123.6, 73.5, 53.8, 51.6, 43.2, 29.5, 23.1.

HRMS (ESI) calcd. for $\mathrm{C}_{22} \mathrm{H}_{21} \mathrm{NNaO}_{6}{ }^{+}(\mathrm{M}+\mathrm{Na})^{+}: 418.1261$, Found: 418.1257 .

\section{Control Experiments}

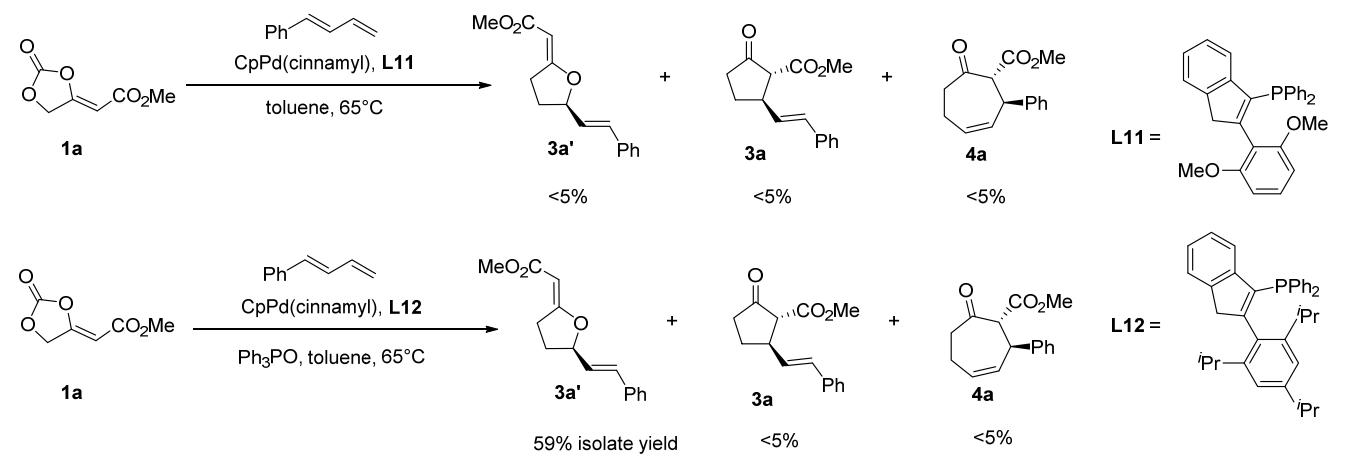

Figure S1. Control Experiments in the Absence of LiOTf

The cycloaddition reactions were investigated using the standard conditions but without the LiOTf additive. In the standard (3+2) cycloaddition conditions (L11 as the ligand), both $\mathbf{3 a} \mathbf{a}^{\prime}, \mathbf{3 a}$, and $\mathbf{4 a}$ were not formed in the absence of LiOTf. In the standard (4+3) cycloaddition conditions (L12 as the ligand), 3a' was obtained in 59\% yield; however, no 3a and $\mathbf{4 a}$ were observed. These control experiments confirmed the key role of LiOTf in the formation of carbocyclic products $\mathbf{3 a}$ and $\mathbf{4 a}$. 


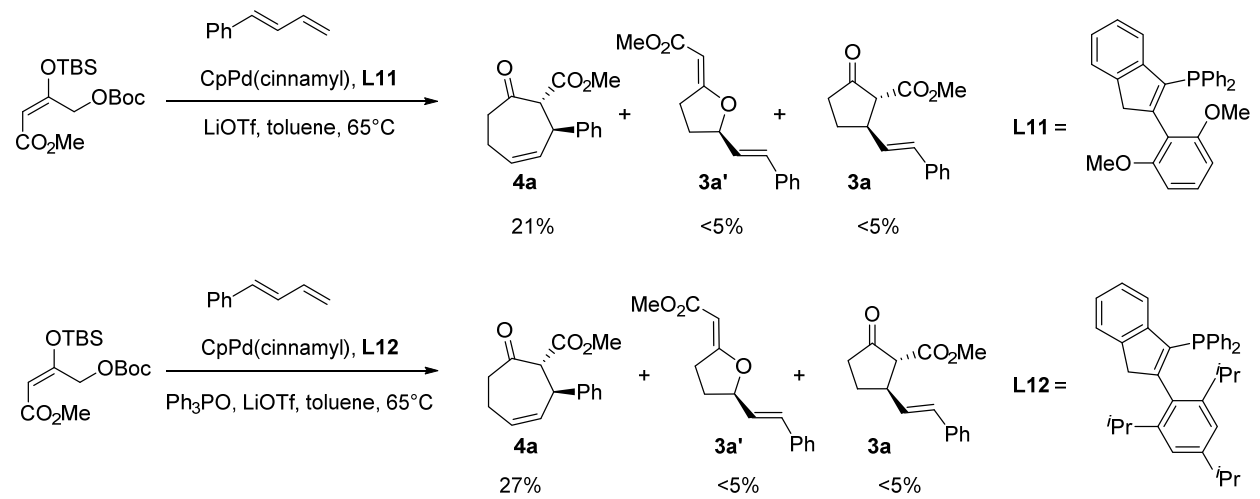

Figure S2. Control Experiments of using Trost's Precusor
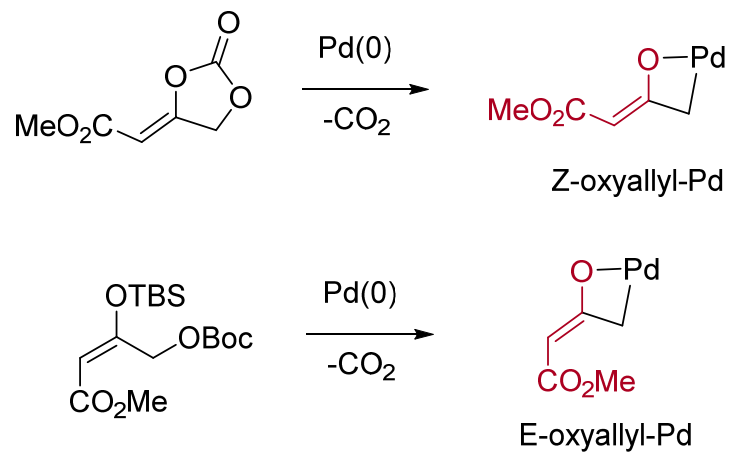

Figure S4. Rationalization of the Different Reactivity

Trost's precursor was also investigated under our standard cycloaddition conditions (Figure S2). We observed $21 \%$ and $27 \%$ yield of $\mathbf{4 a}$ were formed respectively. Although the C-O reductive elimination product $\mathbf{3 \mathbf { a } ^ { \prime }}$ was prohibited in our established conditions; however, the Ligand L11 and $\mathbf{L 1 2}$ failed to control the regioselectivity. We rationalized that the two precursors would result in two different oxyallyl Pd species (Z-type and E type, see Figure S4). The Z-oxyallyl-Pd could coordinate with LiOTf in a bidentate fashion, whereas the E-oxyallyl-Pd coordinates with LiOTf in a monodentate fashion. These differences make the two precursors display different reactivities in our established standard conditions.
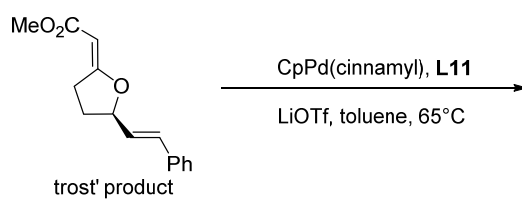

trost' product

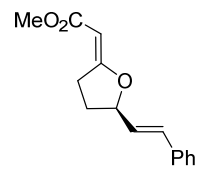

trost's product

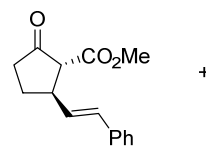

$3 a, 24 \%$ yield

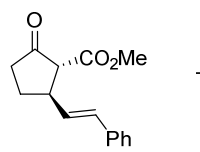

$3 a, 4 \%$ yield

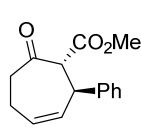

$4 a, 14 \%$ yield

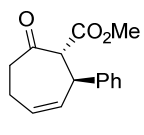

4a, $12 \%$ yield
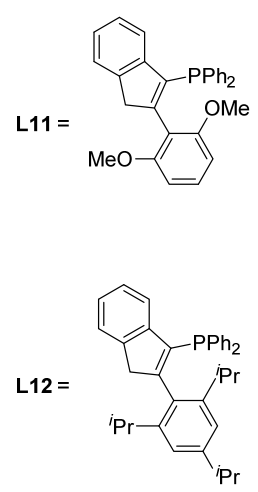

Figure S3. Control Experiments of using Trost's Product

One possible pathway for the cycloaddition reaction is forming oxygen-heterocycle (Trost's product) first, and then the latter undergoes $\mathrm{C}-\mathrm{O}$ rearrangement to give the carbocycles. We 
prepared the Trost's product according to Trost's method and then this product was subjected to our standard cycloaddition conditions (Figure S3). Although the 3a and 4a were observed, the yields and regioselectivities were much worse than that of using the precursor 1a. Therefore, we believe that Trost's product is not likely an intermediate involving in our reaction.

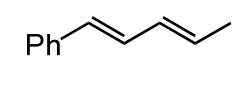

inactive substrates

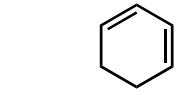

give complexed mixtures

Figure S5. Failed 1,3-Dienes in the $(3+2)$ and $(4+3)$ cycloadditions

Internal 1,3-dienes are inactive substrates in the $(3+2)$ and $(4+3)$ cycloaddition reactions. 1,3-Cyclohexadiene was also investigated in the cycloadditions; however, only complexed mixtures were obtained.

\section{Reference}

[1] Preuß, T.; Saak, W.; Doye, S. Titanium-Catalyzed Intermolecular Hydroaminoalkylation of Conjugated Dienes. Chem. Eur. J. 2013, 19, 3833-3837.

[2] Adamson, N. J.; Hull, E.; Malcolmson, S. J. Enantioselective Intermolecular Addition of Aiphatic Amines to Acyclic Dienes with a Pd-PHOX Catalyst. J. Am. Chem. Soc. 2017, 139, 7180-7183.

[3] Buzas, A.; Gagosz, F. Gold(I)-Catalyzed Formation of 4-Alkylidene-1,3-dioxolan-2-ones from Propargylic tert-Butyl Carbonates. Org. Lett. 2006, 8, 515-518.

[4] Lian, Z.-Y.; Yuan, J.; Yan, M.-Q.; Liu, Y.; Luo, X.; Wu, Q.-G.; Liu, S.-H.; Chen, J.; Zhu, X.-L; Yu,

G.-A. 2-Aryl-indenylphosphine ligands: design, Synthesis and application in Pd-catalyzed Suzuki-Miyaura coupling reactions. Org. Biomol. Chem. 2016, 14, 10090-10094.

[5] Xu, M.-Y.; Jiang, W.-T.; Li, Y.; Xu, Q.-H.; Zhou, Q.-L.; Yang, S.; Xiao, B. Alkyl Carbagermatranes Enable Practical Palladium-Catalyzed $\mathrm{sp}^{2}-\mathrm{sp}^{3}$ Cross-Coupling. J. Am. Chem. Soc. 2019, 141, 7582-7588.

[6] Trost, B. M.; Huang, Z.; Murhade, G. M. Catalytic palladium-oxyallyl cycloaddition. Science 2018, $362,564-568$. 


\section{Computational methods:}

All calculations were carried out with Gaussian 16 program. ${ }^{1}$ Geometry optimization and frequency analysis were performed using B3LYP functional ${ }^{2-5}$ with D3(BJ) dispersion correction ${ }^{6}$, and a mixed basis set of LANL2DZ7-9 for Pd and 6-31G(d) for other atoms. The single-point calculations were further improved by using M06 functional ${ }^{10}$ and a mixed basis set of SDD ${ }^{11}$ for Pd and $6-311++\mathrm{G}(\mathrm{d}, \mathrm{p})$ for other atoms with the SMD model ${ }^{12}$ (toluene as solvent) on the optimized geometries. All the transition states were confirmed by IRC (intrinsic reaction coordinate $)^{13}$ calculation. Gibbs free energy values were the sum of the electronic energy from the single point calculations and the thermal corrections obtained by the frequency calculations. All of the Gibbs energies shown in this article were calculated at $1 \mathrm{~atm}$ and $338.15 \mathrm{~K}$. The energy decomposition analysis was performed with density-fitted SSAPT0 using SAPT module ${ }^{14,15}$ in the PSI4 package ${ }^{16}$. The jun-cc-pVDZ basis set was used ${ }^{17}$, which was optimal with the sSAPT0 level due to the good performance in error cancellation ${ }^{14}$. IGM (independent gradient model) ${ }^{18}$ was performed with Multiwfn 3.7 program $^{19}$ to investigate the weak interaction between the metal center and the ligand.

[1] Frisch, M. J.; Trucks, G. W.; Schlegel, H. B.; Scuseria, G. E.; Robb, M. A.; Cheeseman, J. R.; Scalmani, G.; Barone, V.; Petersson, G. A.; Nakatsuji, H.; Li, X.; Caricato, M.; Marenich, A. V.; Bloino, J.; Janesko, B. G.; Gomperts, R.; Mennucci, B.; Hratchian, H. P.; Ortiz, J. V.; Izmaylov, A. F.; Sonnenberg, J. L.; Williams-Young, D.; Ding, F.; Lipparini, F.; Egidi, F.; Goings, J.; Peng, B.; Petrone, A.; Henderson, T.; Ranasinghe, D.; Zakrzewski, V. G.; Gao, J.; Rega, N.; Zheng, G.; Liang, W.; Hada, M.; Ehara, M.; Toyota, K.; Fukuda, R.; Hasegawa, J.; Ishida, M.; Nakajima, T.; Honda, Y.; Kitao, O.; Nakai, H.; Vreven, T.; Throssell, K.; Montgomery, J. A.; Jr., Peralta, J. E.; Ogliaro, F.; Bearpark, M. J.; Heyd, J. J.; Brothers, E. N.; Kudin, K. N.; Staroverov, V. N.; Keith, T. A.; Kobayashi, R.; Normand, J.; Raghavachari, K.; Rendell, A. P.; Burant, J. C.; Iyengar, S. S.; Tomasi, J.; Cossi, M.; Millam, J. M.; Klene, M.; Adamo, C.; Cammi, R.; Ochterski, J. W.; Martin, R. L.; Morokuma, K.; Farkas, O.; Foresman, J. B.; Fox, D. J. Gaussian 16, Revision A.03; Gaussian, Inc.: Wallingford, CT, 2016.

[2] Becke, A. D. Density-functional thermochemistry. III. The role of exact exchange. J. Chem. Phys. 1993, 98, 5648-5652.

[3] Raghavachari, K. Perspective on "Density functional thermochemistry. III. The role of exact exchange". Theor. Chem. Acc. 2000, 103, 361-363.

[4] Becke, A. D. A new mixing of Hartree-Fock and local density-functional theories. J. Chem. Phys. 1993, 98, 1372-1377.

[5] Lee, C.; Yang, W.; Parr, R. G. Development of the Colle-Salvetti correlation-energy formula into a functional of the electron density. Phys. Rev. B 1988, 37, 785-789.

[6] Grimme, S.; Ehrlich, S.; Goerigk, L. Effect of the Damping Function in Disperision Corrected Density Functional Theory. J. Comput. Chem. 2011, 32, 1456-1465.

[7] Hay, P. J.; Wadt, W. R. Ab initio effective core potentials for molecular calculations. Potentials for the transition metal atoms Sc to Hg. J. Chem. Phys. 1985, 82, 270-283.

[8] Wadt, W. R.; Hay, P. J. Ab initio effective core potentials for molecular calculations. Potentials for main group elements Na to Bi. J. Chem. Phys. 1985, 82, 284-298.

[9] Hay, P. J.; Wadt, W. R. Ab initio effective core potentials for molecular calculations. Potentials for $\mathrm{K}$ to Au including the outermost core orbitals. J. Chem. Phys. 1985, 82, 299-310. 
[10] Zhao, Y.; Truhlar, D. G. The M06 suite of density functionals for main group thermochemistry, thermochemical kinetics, noncovalent interactions, excited states, and transition elements: two new functionals and systematic testing of four Mo6-class functionals and 12 other functionals. Theor. Chem. Acc. 2008, 120, 215-241.

[11] Andrae, D., Häußermann, U., Dolg, M., Stoll, H.; Preuß, H. Energy-adjusted ab initio pseudopotentials for the second and third row transition elements. Theor. Chim. Acta. 1990, 77, 123-141.

[12] Marenich, A. V.; Cramer, C. J.; Truhlar, D. G. Universal Solvation Model Based on Solute Electron Density and on a Continuum Model of the Solvent Defined by the Bulk Dielectric Constant and Atomic Surface Tensions. J. Phys. Chem. B 2009, 113, 6378-6396.

[13] Fukui, K. The path of chemical reactions - the IRC approach. Acc. Chem. Res. 1981, 14, 363-368.

[14] Hohenstein, E. G.; Sherrill, C. D. Density fitting and Cholesky decomposition approximations in symmetry-adapted perturbation theory: Implementation and application to probe the nature of $\pi$ - $\pi$ interactions in linear acenes. J. Chem. Phys. 2010, 132, 184111.

[15] Hohenstein, E. G.; Parrish, R. M.; Sherrill, C. D.; Turney, J. M.; Schaefer III, H. F. Large-scale symmetry-adapted perturbation theory computations via density fitting and Laplace transformation techniques: Investigating the fundamental forces of DNA-intercalator interactions. J. Chem. Phys. 2011, 135, 174107.

[16] Turney, J. M.; Simmonett, A. C.; Parrish, R. M.; Hohenstein, E. G.; Evangelista, F. A.; Fermann, J. T.; Mintz, B. J.; Burns, L. A.; Wilke, J. J.; Abrams, M. L.; Russ, N. J.; Leininger, M. L.; Janssen, C. L.; Seidl, E. T.; Allen, W. D.; Schaefer, H. F.; King, R. A.; Valeev, E. F.; Sherrill, C. D.; Crawford, T. D. PSI4: an open-source ab initio electronic structure program. WIREs Comp. Mol. Sci. 2012, 2, 556-565.

[17] Kendall, R. A.; Dunning, T. H.; Harrison, R. J. Electron affinities of the first-row atoms revisited. Systematic basis sets and wave functions. J. Chem. Phys. 1992, 96, 6796-6806.

[18] Lefebvre, C.; Rubez, G.; Khartabil, H.; Boisson, J.-C.; Contreras-García, J.; Hénon, E. Accurately extracting the signature of intermolecular interactions present in the NCI plot of the reduced density gradient versus electron density. Phys. Chem. Chem. Phys., 2017, 19, 17928-17936.

[19] Lu, T.; Chen, F. Multiwfn: A multifunctional wavefunction analyzer. J. Comput. Chem. 2012, 33, 580-592.

Table S1: The B3LYP-D3(BJ)/LANL2DZ-6-31G(d) computed energies, enthalpies, free energies of all stationary points discussed in the text.

\begin{tabular}{|l|c|c|c|c|c|}
\hline Species & E0 & E0+ZPE & E & H & \multicolumn{1}{c|}{$\mathrm{G}$} \\
\hline LiOTf & -969.046288 & -969.016276 & -969.006077 & -969.005006 & -969.055947 \\
\hline 3a-LiOTf & -1776.074421 & -1775.762587 & -1775.729399 & -1775.728329 & -1775.837055 \\
\hline 4a-LiOTf & -1776.076970 & -1775.763019 & -1775.730695 & -1775.729625 & -1775.832620 \\
\hline 1a & -608.386463 & -608.263651 & -608.251111 & -608.250040 & -608.307426 \\
\hline 2a & -387.089368 & -386.921893 & -386.910612 & -386.909541 & -386.962866 \\
\hline CO2 & -188.582581 & -188.570988 & -188.567882 & -188.566811 & -188.595006 \\
\hline L11-SM & -2347.266884 & -2346.679172 & -2346.627647 & -2346.626576 & -2346.771875 \\
\hline L11-TS0A & -2347.199576 & -2346.614422 & -2346.562908 & -2346.561837 & -2346.707050 \\
\hline L11-TS0B & -2347.219986 & -2346.635820 & -2346.583961 & -2346.582890 & -2346.730339 \\
\hline L11-A & -2347.263896 & -2346.677664 & -2346.625680 & -2346.624610 & -2346.773118 \\
\hline L11-B & -2158.668091 & -2158.097478 & -2158.048725 & -2158.047654 & -2158.187536 \\
\hline
\end{tabular}




\begin{tabular}{|l|r|r|r|r|r|}
\hline L11-B0 & -2545.773364 & -2545.032136 & -2544.970998 & -2544.969927 & -2545.137112 \\
\hline L11-C & -2545.822058 & -2545.076848 & -2545.016970 & -2545.015900 & -2545.179622 \\
\hline L11-D & -3514.977573 & -3514.198864 & -3514.127538 & -3514.126467 & -3514.314663 \\
\hline L11-Ea & -3514.930441 & -3514.153816 & -3514.081411 & -3514.080340 & -3514.273083 \\
\hline L11-Eb & -3514.914785 & -3514.138774 & -3514.065863 & -3514.064792 & -3514.262801 \\
\hline L11-Fa & -3514.955620 & -3514.178140 & -3514.106152 & -3514.105081 & -3514.298306 \\
\hline L11-Fb & -3514.958377 & -3514.179093 & -3514.107981 & -3514.106910 & -3514.293839 \\
\hline L11-TS1 & -2545.758013 & -2545.015734 & -2544.955896 & -2544.954825 & -2545.117435 \\
\hline L11-TS2a & -3514.936269 & -3514.160066 & -3514.088260 & -3514.087190 & -3514.280030 \\
\hline L11-TS2b & -3514.947210 & -3514.169874 & -3514.098833 & -3514.097762 & -3514.285018 \\
\hline L12-A & -2472.095023 & -2471.319150 & -2471.257370 & -2471.256299 & -2471.424806 \\
\hline L12-B & -2283.497655 & -2282.737203 & -2282.678766 & -2282.677695 & -2282.837596 \\
\hline L12-B0 & -2670.593585 & -2669.662509 & -2669.591504 & -2669.590433 & -2669.777628 \\
\hline L12-C & -2670.647692 & -2669.713505 & -2669.643469 & -2669.642398 & -2669.827877 \\
\hline L12-Ea & -3639.779423 & -3638.812521 & -3638.730412 & -3638.729341 & -3638.940275 \\
\hline L12-Eb & -3639.777226 & -3638.810067 & -3638.728047 & -3638.726976 & -3638.939156 \\
\hline L12-Fa & -3639.786003 & -3638.818781 & -3638.737086 & -3638.736015 & -3638.947242 \\
\hline L12-Fb & -3639.776692 & -3638.807909 & -3638.726726 & -3638.725656 & -3638.936332 \\
\hline L12-D & -3639.799801 & -3638.831573 & -3638.750158 & -3638.749087 & -3638.959442 \\
\hline L12-TS1 & -2670.573241 & -2669.642536 & -2669.572439 & -2669.571368 & -2669.758293 \\
\hline L12-TS2a & -3639.764706 & -3638.798690 & -3638.717151 & -3638.716080 & -3638.926553 \\
\hline L12-TS2b & -3639.772280 & -3638.805595 & -3638.724549 & -3638.723479 & -3638.931829 \\
\hline
\end{tabular}

E0 is the electronic energy calculated by using B3LYP-D3(BJ)/LANL2DZ-6-31G(d). ZPE is the Zero-point vibrational energy. $\mathrm{U}, \mathrm{H}$ and $\mathrm{G}$ are the thermal energy, enthalpy and Gibbs free energy obtained by adding the thermal corrections from frequency calculations to E0. All energies are in Hartree.

Table S2: The M06/SDD-6-311++G(d,p)/SMD(toluene)//B3LYP-D3(BJ)/LANL2DZ-6-31G(d) computed energies, enthalpies, free energies of all stationary points discussed in the text.

\begin{tabular}{|l|c|c|c|c|r|}
\hline Species & E0 & E0+ZPE & E & H & \multicolumn{1}{c|}{$\mathrm{G}$} \\
\hline LiOTf & -969.004895 & -968.974882 & -968.964684 & -968.963613 & -969.014554 \\
\hline 3a-LiOTf & -1775.623008 & -1775.311174 & -1775.277986 & -1775.276916 & -1775.385642 \\
\hline 4a-LiOTf & -1775.619459 & -1775.305508 & -1775.273185 & -1775.272114 & -1775.375109 \\
\hline 1a & -608.211553 & -608.088742 & -608.076201 & -608.075131 & -608.132517 \\
\hline 2a & -386.840725 & -386.673250 & -386.661969 & -386.660899 & -386.714223 \\
\hline CO2 & -188.558750 & -188.547157 & -188.544051 & -188.542980 & -188.571175 \\
\hline L11-SM & -2347.499019 & -2346.911307 & -4693.771101 & -2346.858711 & -2347.004010 \\
\hline L11-TS0A & -2347.426086 & -2346.840931 & -2346.789417 & -2346.788346 & -2346.933560 \\
\hline L11-TS0B & -2347.455670 & -2346.871504 & -2346.819645 & -2346.818471 & -2346.966024 \\
\hline L11-B0 & -2545.784210 & -2545.042983 & -2544.981844 & -2544.980773 & -2545.147958 \\
\hline L11-C & -2545.825313 & -2545.080103 & -2545.020225 & -2545.019155 & -2545.182877 \\
\hline L1-CW & -3514.913807 & -3514.135098 & -3514.063772 & -3514.062701 & -3514.250897 \\
\hline
\end{tabular}




\begin{tabular}{|l|r|r|r|r|r|}
\hline L11-Ea & -3514.896638 & -3514.120013 & -3514.047608 & -3514.046537 & -3514.239280 \\
\hline L11-Eb & -3514.889967 & -3514.113956 & -3514.041044 & -3514.039974 & -3514.237983 \\
\hline L11-Fa & -3514.919156 & -3514.141676 & -3514.069688 & -3514.068617 & -3514.261841 \\
\hline L11-Fb & -3514.910705 & -3514.131421 & -3514.060309 & -3514.059238 & -3514.246167 \\
\hline L11-TS1 & -2545.767236 & -2545.024958 & -2544.965119 & -2544.964048 & -2545.126658 \\
\hline L11-TS2a & -3514.890060 & -3514.113857 & -3514.042051 & -3514.040981 & -3514.233821 \\
\hline L11-TS2b & -3514.892282 & -3514.114946 & -3514.043905 & -3514.042834 & -3514.230090 \\
\hline L12-A & -2472.143864 & -2471.367990 & -2471.306210 & -2471.305139 & -2471.473647 \\
\hline L12-B & -2283.580808 & -2282.820356 & -2282.761919 & -2282.760848 & -2282.920749 \\
\hline L12-B0 & -2670.428062 & -2669.496986 & -2669.425980 & -2669.424910 & -2669.612105 \\
\hline L12-C & -2670.476067 & -2669.541880 & -2669.471844 & -2669.470773 & -2669.656252 \\
\hline L12-Ea & -3639.555900 & -3638.588998 & -3638.506889 & -3638.505818 & -3638.716752 \\
\hline L12-Eb & -3639.554828 & -3638.587669 & -3638.505649 & -3638.504578 & -3638.716758 \\
\hline L12-Fa & -3639.568293 & -3638.601071 & -3638.519376 & -3638.518305 & -3638.729532 \\
\hline L12-Fb & -3639.557154 & -3638.588371 & -3638.507188 & -3638.506118 & -3638.716794 \\
\hline L12-CW & -3639.561072 & -3638.592845 & -3638.511429 & -3638.510359 & -3638.720713 \\
\hline L12-TS1 & -2670.408821 & -2669.478116 & -2669.408019 & -2669.406948 & -2669.593873 \\
\hline L12-TS2a & -3639.540035 & -3638.574019 & -3638.492480 & -3638.491409 & -3638.701883 \\
\hline L12-TS2b & -3639.544662 & -3638.577977 & -3638.496931 & -3638.495860 & -3638.704211 \\
\hline
\end{tabular}

E0 is the electronic energy calculated by using M06/SDD-6-311++G(d,p)/SMD(toluene) based on geometries obtained by B3LYP-D3(BJ)/LANL2DZ-6-31G(d). ZPE is the Zero-point vibrational energy. $\mathrm{U}, \mathrm{H}$ and $\mathrm{G}$ are the results of adding corresponding corrections the same as in Table $\mathrm{S} 1$ to E0. All energies are in Hartree.

Table S3: The M06/SDD-6-311++G(d,p)/SMD(toluene) computed energies of the species involved in the calculation of the interaction energy $\left(\Delta E_{\text {int }}\right)$ of the active catalyst $\mathrm{PdL}$ and the substrate $^{\mathrm{a}}$

\begin{tabular}{|l|c|c|c|c|}
\hline transition state & $E_{\mathrm{TS}}(. \mathrm{a} . \mathrm{u})$ & $E_{\text {sub }}(. \mathrm{a} . \mathrm{u})$ & $E_{\mathrm{PdL}}(. \mathrm{a} . \mathrm{u})$ & $\Delta E_{\text {int }}$ ( $(\mathrm{kcal} / \mathrm{mol})$ \\
\hline L11-TS2a & -3514.890060 & -1775.574869 & -1739.230370 & -53.22 \\
\hline L11-TS2b & -3514.892282 & -1775.574702 & -1739.233036 & -53.05 \\
\hline L12-TS2a & -3639.540035 & -1775.572307 & -1863.880748 & -54.58 \\
\hline L12-TS2b & -3639.544662 & -1775.572424 & -1863.885012 & -54.73 \\
\hline
\end{tabular}

${ }^{\mathrm{a}} \mathrm{E}_{\mathrm{TS}}$ is the single point energy of the transition state, $\mathrm{E}_{\text {sub }}$ and $\mathrm{E}_{\mathrm{PdL}}$ are the single point energies of the substrate and the active catalyst PdL at their transition state geometries, respectively.

${ }^{\mathrm{b}} \Delta E_{\mathrm{int}}=E_{\mathrm{TS}}-E_{\mathrm{sub}}-E_{\mathrm{PdL}}$

The Cartesian Coordinates of the stationary points discussed in the text. For transition state structures, one imaginary frequency was observed and given below. For all minimum structures, no imaginary frequency was observed.

\section{LiOTf}

Atom

$\begin{array}{ccccc} & \text { C } & 1.039818 & 0.077025 & 0.000057 \\ & \text { F } & 1.616751 & -0.428071 & 1.088456 \\ & \text { F } & 1.616516 & -0.428934 & -1.088212 \\ & \text { F } & 1.206725 & 1.414702 & -0.000526\end{array}$




$$
\begin{array}{cccc}
\mathrm{S} & -0.782954 & -0.290615 & 0.000044 \\
\mathrm{O} & -0.937905 & -1.735420 & 0.000153 \\
\mathrm{O} & -1.279072 & 0.479848 & -1.204091 \\
\mathrm{O} & -1.278920 & 0.480005 & 1.204137 \\
\mathrm{Li} & -1.901463 & 1.790987 & -0.000037
\end{array}
$$

\section{3a-LiOTf}

$$
\begin{aligned}
& \text { Atom } \mathrm{X} \quad \mathrm{Y} \quad \mathrm{Z} \\
& \text { O } \quad-1.642448 \quad 2.555974-0.775418 \\
& \text { O } \quad 0.455376 \quad 2.078325-1.414672 \\
& \text { C } \quad-4.751481-1.926170-0.829561 \\
& \mathrm{H} \quad-4.019035-2.510207-1.381300 \\
& \text { C } \quad-6.111553-2.155179-1.027618 \\
& \text { H } \quad-6.433246-2.915815-1.733266 \\
& \text { C } \quad-7.055034-1.409719-0.321309 \\
& \text { H } \quad-8.116248-1.584502-0.472733 \\
& \text { C } \quad-6.625321-0.433564 \quad 0.582532 \\
& \begin{array}{llll}
\mathrm{H} & -7.354024 & 0.153401 & 1.134742
\end{array} \\
& \text { C } \quad-5.267643-0.205939 \quad 0.779100 \\
& \begin{array}{llll}
\mathrm{H} & -4.953327 & 0.560834 & 1.480677
\end{array} \\
& \text { C } \quad-4.303218-0.951652 \quad 0.077473 \\
& \begin{array}{llll}
\text { C } & -0.757058 & 0.211068 & 1.176077
\end{array} \\
& \text { H } \quad-0.275963-0.460658 \quad 0.458415 \\
& \text { C } \quad-0.141327-0.039812 \quad 2.579090 \\
& \begin{array}{llll}
\text { C } & -0.240917 & 1.658619 & 0.877128
\end{array} \\
& \begin{array}{llll}
\mathrm{H} & -0.802208 & 2.344470 & 1.528757
\end{array} \\
& \text { C } \quad-0.408832 \quad 2.118293-0.546927 \\
& \text { C } \quad-1.953256 \quad 2.922834-2.138086 \\
& \mathrm{H} \quad-1.797832 \quad 2.067235-2.798166 \\
& \mathrm{H} \quad-1.319640 \quad 3.752846-2.457483 \\
& \mathrm{H} \quad-3.001806 \quad 3.215518-2.121068 \\
& \text { C } \quad-2.858921-0.754041 \quad 0.243084 \\
& \text { H } \quad-2.234788-1.360526-0.413866 \\
& \begin{array}{llll}
\text { C } & -2.240411 & 0.072521 & 1.098685
\end{array} \\
& \mathrm{H} \quad-2.815157 \quad 0.698270 \quad 1.781931 \\
& \text { C } \quad 1.196472 \quad 1.601686 \quad 1.392670 \\
& \begin{array}{llll}
\text { O } & 2.143484 & 2.199536 & 0.908550
\end{array} \\
& \text { Li } \quad 2.250138 \quad 1.463952-1.012845 \\
& \text { S } \quad 3.140032-0.850208-1.157518 \\
& \text { O } \quad 3.195311-2.054659-1.977110 \\
& \text { O } \quad 3.688048 \quad 0.419071-1.747297 \\
& \text { O } \quad 1.830444-0.520302-0.499209 \\
& \text { C } \quad 4.253765-1.163311 \quad 0.298157 \\
& \text { F } \quad 5.490938-1.459982-0.098033
\end{aligned}
$$

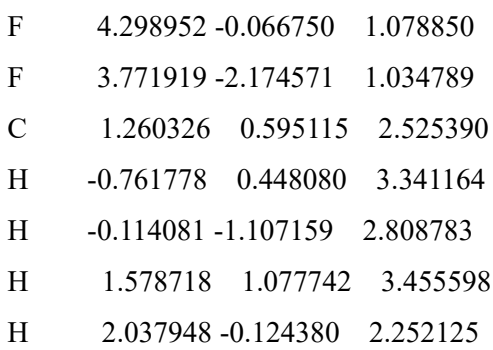

$$
\begin{aligned}
& \text { 4a-LiOTf } \\
& \begin{array}{llll}
\text { Atom } & \mathrm{X} & \mathrm{Y} & \mathrm{Z}
\end{array} \\
& \text { O } \quad-3.051022 \quad 0.147438 \quad 1.926682 \\
& \text { O } \quad-1.004773-0.774330 \quad 1.959764 \\
& \text { C } \quad-1.976132-1.507391-1.136636 \\
& \text { H } \quad-0.940347-1.808608-1.011352 \\
& \text { C } \quad-2.969701-2.462584-1.362075 \\
& \text { H } \quad-2.698645-3.512743-1.422132 \\
& \text { C } \quad-4.300155-2.071346-1.515310 \\
& \mathrm{H} \quad-5.071753-2.815474-1.691703 \\
& \text { C } \quad-4.636182-0.717087-1.446935 \\
& \text { H } \quad-5.669734-0.404495-1.566810 \\
& \text { C } \quad-3.645242 \quad 0.236287-1.222594 \\
& \mathrm{H} \quad-3.915315 \quad 1.287432-1.156864 \\
& \text { C } \quad-2.307919-0.149380-1.066063 \\
& \text { C } \quad-1.229623 \quad 0.870296-0.745251 \\
& \mathrm{H} \quad-0.260472 \quad 0.367281-0.817997 \\
& \text { C } \quad-1.257298 \quad 2.057082-1.682765 \\
& \text { H } \quad-2.013216 \quad 2.011269-2.462443 \\
& \text { C } \quad-0.432972 \quad 3.110548-1.670432 \\
& \text { H } \quad-0.575344 \quad 3.864609-2.441925 \\
& \text { C } \quad 0.681585 \quad 3.370672-0.689846 \\
& \text { H } \quad 1.128119 \quad 4.347840-0.894750 \\
& \mathrm{H} \quad 1.484862 \quad 2.630389-0.800451 \\
& \begin{array}{llll}
\text { C } & 0.227775 & 3.367958 & 0.800869
\end{array} \\
& \begin{array}{llll}
\text { H } & 1.039257 & 3.746247 & 1.427627
\end{array} \\
& \mathrm{H} \quad-0.656262 \quad 4.002638 \quad 0.915846 \\
& \begin{array}{llll}
\text { C } & -1.368719 & 1.330008 & 0.785154
\end{array} \\
& \text { H } \quad-2.172103 \quad 2.066601 \quad 0.834344 \\
& \begin{array}{llll}
\text { C } & -1.757687 & 0.131822 & 1.626652
\end{array} \\
& \text { C } \quad-3.581648-1.060276 \quad 2.518290 \\
& \mathrm{H} \quad-3.078823-1.272968 \quad 3.463457 \\
& \text { H } \quad-3.441538-1.890771 \quad 1.823348 \\
& \text { H } \quad-4.639995-0.857948 \quad 2.674139 \\
& \begin{array}{llll}
\text { C } & -0.049830 & 1.951475 & 1.219747
\end{array} \\
& \begin{array}{llll}
\text { O } & 0.821567 & 1.293587 & 1.777901
\end{array}
\end{aligned}
$$




$$
\begin{aligned}
& \text { Li } \quad 0.909168-0.670492 \quad 1.619975 \\
& \text { S } \quad 2.600731-1.595936 \quad 0.080838 \\
& \text { O } \quad 1.227312-1.136083-0.329521 \\
& \text { O } \quad 2.675131-1.509386 \quad 1.576462 \\
& \text { O } \quad 3.123136-2.797108-0.559427 \\
& \text { C } \quad 3.679281-0.195045-0.498983 \\
& \begin{array}{llll}
\text { F } & 3.240649 & 0.968801 & 0.023000
\end{array} \\
& \text { F } \quad 4.943166-0.381073-0.115839 \\
& \text { F } \quad 3.633750-0.097286-1.831993
\end{aligned}
$$

\section{$1 a$}

$$
\begin{array}{lcccc}
\text { Atom } & \mathrm{X} & \mathrm{Y} & \mathrm{Z} \\
\mathrm{C} & -1.781235 & -0.068031 & -0.000566 \\
\mathrm{O} & -2.979564 & 0.570679 & -0.000054 \\
\mathrm{C} & -4.121990 & -0.297481 & 0.000446 \\
\mathrm{H} & -4.119947 & -0.933976 & 0.889328 \\
\mathrm{H} & -4.990434 & 0.361535 & 0.000818 \\
\mathrm{H} & -4.120713 & -0.933985 & -0.888432 \\
\mathrm{O} & -1.661605 & -1.275032 & -0.000092 \\
\mathrm{C} & -0.693118 & 0.924480 & -0.000338 \\
\mathrm{H} & -0.970324 & 1.972799 & -0.000364 \\
\mathrm{C} & 0.608487 & 0.617744 & -0.000112 \\
\mathrm{C} & 1.783348 & 1.568109 & 0.000099 \\
\mathrm{H} & 1.819240 & 2.200150 & 0.892804 \\
\mathrm{H} & 1.819521 & 2.200201 & -0.892557 \\
\mathrm{O} & 1.118198 & -0.646431 & -0.000058 \\
\mathrm{O} & 2.914843 & 0.691749 & 0.000256 \\
\mathrm{C} & 2.503915 & -0.598504 & 0.000265 \\
\mathrm{O} & 3.203906 & -1.559043 & -0.000097
\end{array}
$$

$$
\begin{array}{lccc}
\text { 2a } & & & \\
\text { Atom } & \mathrm{X} & \mathrm{Y} & \mathrm{Z} \\
\mathrm{C} & -2.288357 & 1.395410 & 0.000000 \\
\mathrm{C} & -0.935885 & 1.073416 & -0.000004 \\
\mathrm{C} & -0.512712 & -0.269584 & -0.000011 \\
\mathrm{C} & -1.500764 & -1.270560 & 0.000002 \\
\mathrm{C} & -2.855718 & -0.948841 & 0.000017 \\
\mathrm{C} & -3.256806 & 0.387184 & 0.000004 \\
\mathrm{H} & -2.591283 & 2.438918 & -0.000013 \\
\mathrm{H} & -0.200206 & 1.871685 & -0.000021 \\
\mathrm{H} & -1.193216 & -2.313488 & 0.000004 \\
\mathrm{H} & -3.598351 & -1.741874 & 0.000022 \\
\mathrm{H} & -4.312449 & 0.642947 & 0.000005 \\
\mathrm{C} & 0.894372 & -0.667006 & -0.000016
\end{array}
$$

$$
\begin{aligned}
& \mathrm{H} \quad 1.067428-1.743667-0.000004 \\
& \text { C } \quad 1.976469 \quad 0.139217-0.000010 \\
& \begin{array}{llll}
\mathrm{H} & 1.855725 & 1.221739 & 0.000000
\end{array} \\
& \text { C } \quad 3.339737-0.352114-0.000007 \\
& \text { H } \quad 3.462459-1.435602-0.000027 \\
& \begin{array}{llll}
\text { C } & 4.428410 & 0.433191 & 0.000020
\end{array} \\
& \begin{array}{llll}
\mathrm{H} & 4.345520 & 1.517677 & 0.000041
\end{array} \\
& \begin{array}{llll}
\mathrm{H} & 5.431892 & 0.019780 & 0.000022
\end{array}
\end{aligned}
$$

$\begin{array}{llcl}\text { L11-SM } & & \\ \text { Atom X } & \mathrm{Y} & \mathrm{Z} \\ \mathrm{C} & -2.57289000 & 1.55378100 & 1.33397900 \\ \mathrm{H} & -2.23161000 & 1.87777900 & 2.31219900 \\ \mathrm{C} & -3.16302000 & 0.28315900 & 1.20937800 \\ \mathrm{C} & -2.68482200 & 2.59963600 & 0.30294900 \\ \mathrm{O} & -3.16213800 & 2.49651100 & -0.81246000 \\ \mathrm{O} & -2.14262700 & 3.76758600 & 0.76004000 \\ \mathrm{C} & -2.17028400 & 4.84456200 & -0.18372400 \\ \mathrm{H} & -1.71097700 & 5.69233900 & 0.32655900 \\ \mathrm{H} & -1.60368700 & 4.58390900 & -1.08199700 \\ \mathrm{H} & -3.19814300 & 5.08081600 & -0.47162400 \\ \mathrm{O} & -4.17099000 & -0.00951900 & 0.27489400 \\ \mathrm{C} & -3.42134200 & -0.65995000 & 2.37237000 \\ \mathrm{C} & -4.78541100 & -1.17377400 & 0.61714200 \\ \mathrm{O} & -5.62825100 & -1.72124200 & -0.03441600 \\ \mathrm{O} & -4.31005100 & -1.63334000 & 1.80485400 \\ \mathrm{C} & 3.26012800 & -2.73923200 & -1.09043700 \\ \mathrm{C} & 3.26174900 & -1.46673100 & -0.47678100 \\ \mathrm{C} & 4.45436500 & -0.89969000 & -0.02346200 \\ \mathrm{C} & 5.64230100 & -1.61661100 & -0.19366000 \\ \mathrm{C} & 5.64004500 & -2.87594300 & -0.80101300 \\ \mathrm{C} & 4.44295900 & -3.44652000 & -1.25329900 \\ \mathrm{C} & 1.87412500 & -0.97408700 & -0.44270500 \\ \mathrm{H} & 4.46075300 & 0.07193600 & 0.45821800 \\ \mathrm{H} & 6.57868000 & -1.18948700 & 0.15434900 \\ \mathrm{H} & 6.57388400 & -3.41749300 & -0.92269000 \\ \mathrm{H} & 4.44556700 & -4.42616800 & -1.72472900 \\ \mathrm{C} & 1.84465300 & -3.09559600 & -1.47450700\end{array}$




\begin{tabular}{|c|c|c|c|c|c|c|c|}
\hline $\mathrm{H}$ & 1.72625900 & -3.24133000 & -2.55741700 & $\mathrm{H}$ & 0.28736200 & 1.94004400 & -3.31982800 \\
\hline $\mathrm{H}$ & 1.48586300 & -4.01348800 & -0.99297600 & $\mathrm{H}$ & -1.05815000 & 1.10052500 & -4.14384500 \\
\hline $\mathrm{C}$ & 1.04526900 & -1.89448600 & -1.00510300 & $\mathrm{H}$ & -3.92676500 & -0.17139700 & 3.21661600 \\
\hline $\mathrm{C}$ & -0.41417100 & -1.78053700 & -1.21945900 & $\mathrm{H}$ & -2.52506600 & -1.16790700 & 2.73165300 \\
\hline C & -1.30411800 & -2.74609800 & -0.68370700 & & & & \\
\hline $\mathrm{C}$ & -0.94614200 & -0.81387000 & -2.11889700 & \multicolumn{4}{|c|}{ L11-TS0A } \\
\hline C & -2.65214500 & -2.77171500 & -1.05353100 & Atc & $X$ & $\mathrm{Y}$ & $\mathrm{Z}$ \\
\hline $\mathrm{C}$ & -2.29899000 & -0.83714000 & -2.48039100 & $\mathrm{C}$ & -3.22799800 & 0.58828200 & 1.44848800 \\
\hline C & -3.12795800 & -1.82180300 & -1.95734900 & $\mathrm{H}$ & -2.55240300 & 1.04067400 & 2.16391600 \\
\hline $\mathrm{H}$ & -3.33594700 & -3.49893200 & -0.63685400 & $\mathrm{C}$ & -3.13438800 & -0.74019700 & 1.24273600 \\
\hline $\mathrm{H}$ & -2.70532000 & -0.08220000 & -3.13970400 & $\mathrm{C}$ & -4.18274400 & 1.47043800 & 0.77317400 \\
\hline $\mathrm{H}$ & -4.18099800 & -1.82598100 & -2.21371000 & $\mathrm{O}$ & -5.01417000 & 1.17051100 & -0.06089300 \\
\hline $\mathrm{C}$ & 1.73415700 & 1.93111300 & -0.73271400 & $\mathrm{O}$ & -4.01205300 & 2.75252400 & 1.21512200 \\
\hline $\mathrm{C}$ & 2.72212500 & 1.81468100 & -1.71845600 & $\mathrm{C}$ & -4.91599400 & 3.70591400 & 0.64559200 \\
\hline $\mathrm{C}$ & 1.07618800 & 3.15802300 & -0.55636600 & $\mathrm{H}$ & -4.67709100 & 4.65770500 & 1.12126400 \\
\hline $\mathrm{C}$ & 3.04797100 & 2.91287700 & -2.51586400 & $\mathrm{H}$ & -4.77749800 & 3.77360700 & -0.43757400 \\
\hline $\mathrm{H}$ & 3.22518000 & 0.86666000 & -1.87258000 & $\mathrm{H}$ & -5.95254100 & 3.42278300 & 0.84690200 \\
\hline $\mathrm{C}$ & 1.41808500 & 4.25815900 & -1.34270600 & $\mathrm{O}$ & -3.89975400 & -1.43156100 & 0.35868000 \\
\hline $\mathrm{H}$ & 0.28643500 & 3.24077500 & 0.18536500 & $\mathrm{C}$ & -2.21933300 & -1.61520500 & 1.98937200 \\
\hline $\mathrm{C}$ & 2.40079300 & 4.13618700 & -2.32805800 & $\mathrm{H}$ & -2.67598200 & -2.32700800 & 2.67469500 \\
\hline $\mathrm{H}$ & 3.80929200 & 2.81204800 & -3.28437300 & $\mathrm{H}$ & -1.36029200 & -1.11724600 & 2.43040800 \\
\hline $\mathrm{H}$ & 0.90846200 & 5.20620000 & -1.19567300 & $\mathrm{C}$ & -3.32805600 & -2.66063100 & 0.01011000 \\
\hline $\mathrm{H}$ & 2.65794500 & 4.98929100 & -2.94955100 & $\mathrm{O}$ & -3.85131600 & -3.35934600 & -0.81351500 \\
\hline $\mathrm{C}$ & 2.17409700 & 0.69176000 & 1.84127300 & $\mathrm{O}$ & -2.22719500 & -2.92570000 & 0.69787000 \\
\hline$C$ & 2.92401000 & 1.83125500 & 2.15472500 & $\mathrm{C}$ & 3.26610900 & 1.76635000 & -2.32536700 \\
\hline$C$ & 2.14472000 & -0.38018100 & 2.74666200 & $\mathrm{C}$ & 3.22215400 & 1.24734600 & -1.01131500 \\
\hline $\mathrm{C}$ & 3.63898700 & 1.89400700 & 3.35305600 & $\mathrm{C}$ & 4.28378200 & 1.48244100 & -0.13500200 \\
\hline$U$ & 2.95849400 & 2.66467000 & 1.46063900 & $\mathrm{C}$ & 5.37935800 & 2.22427400 & -0.58613800 \\
\hline $\mathrm{C}$ & 2.86690800 & -0.31890800 & 3.93557800 & $\mathrm{C}$ & 5.42305900 & 2.72674900 & -1.88909700 \\
\hline $\mathrm{H}$ & 1.56437200 & -1.26783000 & 2.50717400 & $\mathrm{C}$ & 4.35817600 & 2.49894500 & -2.76871000 \\
\hline$C$ & 3.61584000 & 0.82052100 & 4.24322400 & $\mathrm{C}$ & 1.93627700 & 0.52891400 & -0.84605000 \\
\hline П & 4.21921300 & 2.78267900 & 3.58600900 & $\mathrm{H}$ & 4.27291500 & 1.09646900 & 0.87553900 \\
\hline $\mathrm{H}$ & 2.84652300 & -1.15976300 & 4.62331300 & $\mathrm{H}$ & 6.20966500 & 2.40947900 & 0.08984100 \\
\hline $\mathrm{H}$ & 4.17694600 & 0.86951300 & 5.17205000 & $\mathrm{H}$ & 6.28485400 & 3.29927700 & -2.22036200 \\
\hline$P$ & 1.18592500 & 0.52868000 & 0.30328100 & $\mathrm{H}$ & 4.38590500 & 2.89468700 & -3.78097900 \\
\hline $\mathrm{Pd}$ & -1.12917600 & 0.17084600 & 0.53388700 & $\mathrm{C}$ & 1.99369600 & 1.39874400 & -3.04098600 \\
\hline $\mathrm{O}$ & -0.05660900 & 0.08458800 & -2.61654200 & $\mathrm{H}$ & 1.41643300 & 2.27420900 & -3.36593600 \\
\hline $\mathrm{O}$ & -0.74556400 & -3.62048600 & 0.20324900 & $\mathrm{H}$ & 2.16428200 & 0.78297200 & -3.93536200 \\
\hline $\mathrm{C}$ & -1.62256800 & -4.48231500 & 0.91715200 & $\mathrm{C}$ & 1.22249000 & 0.61758600 & -2.00131600 \\
\hline $\mathrm{H}$ & -0.99757100 & -5.01152500 & 1.63802500 & $\mathrm{C}$ & -0.15313400 & 0.13880100 & -2.23988500 \\
\hline $\mathrm{H}$ & -2.39540900 & -3.90822700 & 1.44297800 & $\mathrm{C}$ & -0.43155700 & -1.20394800 & -2.55010200 \\
\hline П & -2.10394500 & -5.20812000 & 0.24997100 & $\mathrm{C}$ & -1.22222400 & 1.04244500 & -2.11534400 \\
\hline $\mathrm{C}$ & -0.57622500 & 1.29053800 & -3.17717400 & $\mathrm{C}$ & -1.75585400 & -1.64334200 & -2.68115700 \\
\hline $\mathrm{H}$ & -1.29090300 & 1.75834100 & -2.49132400 & $\mathrm{C}$ & -2.54704600 & 0.61414600 & -2.22839100 \\
\hline
\end{tabular}




\begin{tabular}{|c|c|c|c|c|c|c|c|}
\hline $\mathrm{C}$ & -2.79369200 & -0.72977100 & -2.50215800 & $\mathrm{C}$ & -2.51673100 & 2.67543100 & 0.31581600 \\
\hline $\mathrm{H}$ & -1.98730600 & -2.68118600 & -2.87985700 & $\mathrm{O}$ & -2.74519600 & 2.69729300 & -0.87741800 \\
\hline $\mathrm{H}$ & -3.37915000 & 1.28668200 & -2.07190700 & $\mathrm{O}$ & -2.15835800 & 3.78458600 & 1.01929200 \\
\hline $\mathrm{H}$ & -3.81858300 & -1.07958600 & -2.55563300 & $\mathrm{C}$ & -2.15922500 & 5.00241500 & 0.26153900 \\
\hline $\mathrm{C}$ & 0.64971700 & 0.99459900 & 1.71108100 & $\mathrm{H}$ & -1.72416400 & 5.75739200 & 0.91710500 \\
\hline $\mathrm{C}$ & 0.30130000 & 2.24726500 & 1.18761200 & $\mathrm{H}$ & -1.57246800 & 4.88924100 & -0.65222600 \\
\hline $\mathrm{C}$ & 0.30637700 & 0.69449700 & 3.04196800 & $\mathrm{H}$ & -3.18241700 & 5.27731700 & -0.01077400 \\
\hline $\mathrm{C}$ & -0.37909200 & 3.17514900 & 1.97706300 & $\mathrm{O}$ & -4.09343900 & 0.20305600 & -0.21506900 \\
\hline $\mathrm{H}$ & 0.53286000 & 2.47986900 & 0.15495700 & $\mathrm{C}$ & -3.26493600 & -0.79455000 & 1.72146200 \\
\hline $\mathrm{C}$ & -0.35688800 & 1.63227800 & 3.83329500 & $\mathrm{C}$ & -5.26214900 & -0.68770900 & 0.09797400 \\
\hline $\mathrm{H}$ & 0.56375500 & -0.27628200 & 3.45855400 & $\mathrm{O}$ & -5.99242600 & -0.87738500 & -0.84564900 \\
\hline $\mathrm{C}$ & -0.70910700 & 2.87493200 & 3.29980300 & $\mathrm{O}$ & -5.26812800 & -1.08380100 & 1.30317800 \\
\hline $\mathrm{H}$ & -0.65581600 & 4.13670500 & 1.55438600 & $\mathrm{C}$ & 3.54676600 & -2.48771800 & -1.00155000 \\
\hline $\mathrm{H}$ & -0.60658200 & 1.38902300 & 4.86242300 & $\mathrm{C}$ & 3.38990300 & -1.16400400 & -0.53640900 \\
\hline $\mathrm{H}$ & -1.24187900 & 3.59922100 & 3.90862800 & $\mathrm{C}$ & 4.50287400 & -0.34878900 & -0.32478500 \\
\hline $\mathrm{C}$ & 2.81721000 & -0.97257400 & 1.43938800 & $\mathrm{C}$ & 5.77241700 & -0.87300900 & -0.58265700 \\
\hline $\mathrm{C}$ & 3.35781300 & -0.46282300 & 2.62664900 & $\mathrm{C}$ & 5.92784600 & -2.18482400 & -1.04146100 \\
\hline $\mathrm{C}$ & 3.46104200 & -2.04272500 & 0.79963000 & $\mathrm{C}$ & 4.81072000 & -3.00287300 & -1.25352100 \\
\hline $\mathrm{C}$ & 4.52315100 & -1.01417500 & 3.16275000 & $\mathrm{C}$ & 1.94913600 & -0.90867700 & -0.36297600 \\
\hline $\mathrm{H}$ & 2.88374200 & 0.37633900 & 3.12418600 & $\mathrm{H}$ & 4.38900300 & 0.66684400 & 0.03709800 \\
\hline $\mathrm{C}$ & 4.63311400 & -2.57923900 & 1.32713600 & $\mathrm{H}$ & 6.64958500 & -0.25249600 & -0.42248100 \\
\hline $\mathrm{H}$ & 3.03903000 & -2.44801200 & -0.11645100 & $\mathrm{H}$ & 6.92354200 & -2.57337200 & -1.23530700 \\
\hline $\mathrm{C}$ & 5.16570900 & -2.06884000 & 2.51371000 & $\mathrm{H}$ & 4.93595300 & -4.02163700 & -1.61155900 \\
\hline $\mathrm{H}$ & 4.93304800 & -0.61072800 & 4.08460900 & $\mathrm{C}$ & 2.18512100 & -3.12178500 & -1.14079000 \\
\hline $\mathrm{H}$ & 5.12795200 & -3.40038600 & 0.81636700 & $\mathrm{H}$ & 1.96438100 & -3.42151700 & -2.17504100 \\
\hline $\mathrm{H}$ & 6.07506300 & -2.49265300 & 2.92994900 & $\mathrm{H}$ & 2.06198000 & -4.01736800 & -0.52098500 \\
\hline $\mathrm{P}$ & 1.30037800 & -0.33406800 & 0.62851600 & $\mathrm{C}$ & 1.23945100 & -2.01999200 & -0.69653100 \\
\hline $\mathrm{Pd}$ & -0.35266400 & -1.82528600 & 0.36673400 & $\mathrm{C}$ & -0.23063100 & -2.19149800 & -0.72152800 \\
\hline $\mathrm{O}$ & -0.84931500 & 2.33745200 & -1.86559300 & $\mathrm{C}$ & -0.83884100 & -3.25316100 & -0.00060000 \\
\hline $\mathrm{O}$ & 0.66205600 & -2.00711700 & -2.70709300 & $\mathrm{C}$ & -1.03857600 & -1.46170000 & -1.64284000 \\
\hline $\mathrm{C}$ & 0.44228400 & -3.40598300 & -2.82536400 & $\mathrm{C}$ & -2.18619700 & -3.57395600 & -0.18193500 \\
\hline $\mathrm{H}$ & 1.43375400 & -3.85959800 & -2.86662400 & $\mathrm{C}$ & -2.39844700 & -1.77315500 & -1.80449500 \\
\hline $\mathrm{H}$ & -0.10365000 & -3.79211800 & -1.95550500 & $\mathrm{C}$ & -2.94904800 & -2.82516800 & -1.08450200 \\
\hline $\mathrm{H}$ & -0.10857400 & -3.65072800 & -3.74208700 & $\mathrm{H}$ & -2.64889100 & -4.38095200 & 0.37154300 \\
\hline $\mathrm{C}$ & -1.86238300 & 3.28110400 & -1.55613700 & $\mathrm{H}$ & -3.02821500 & -1.18213300 & -2.45437300 \\
\hline $\mathrm{H}$ & -2.37439700 & 3.01872000 & -0.62493900 & $\mathrm{H}$ & -4.00545100 & -3.04334400 & -1.20507200 \\
\hline $\mathrm{H}$ & -1.34820000 & 4.23606800 & -1.42974100 & $\mathrm{C}$ & 1.42816400 & 1.87839500 & -0.99728300 \\
\hline \multirow[t]{2}{*}{$\mathrm{H}$} & -2.59245500 & 3.37061900 & -2.37003000 & $\mathrm{C}$ & 2.14516400 & 1.63073500 & -2.17458800 \\
\hline & & & & $\mathrm{C}$ & 0.85264900 & 3.14180400 & -0.79265400 \\
\hline \multicolumn{2}{|c|}{ L11-TS0B } & & & $\mathrm{C}$ & 2.29248600 & 2.63817100 & -3.12902900 \\
\hline Ato & $\mathrm{X}$ & $\mathrm{Y}$ & Z & $\mathrm{H}$ & 2.57639500 & 0.65243100 & -2.35064700 \\
\hline $\mathrm{C}$ & -2.56434800 & 1.49785200 & 1.20396100 & $\mathrm{C}$ & 1.01961200 & 4.15054200 & -1.73984000 \\
\hline $\mathrm{H}$ & -2.36124800 & 1.67977800 & 2.25523400 & $\mathrm{H}$ & 0.27019800 & 3.32887700 & 0.10491400 \\
\hline $\mathrm{C}$ & -3.30371600 & 0.33189700 & 0.85827000 & $\mathrm{C}$ & 1.73583800 & 3.89972000 & -2.91249800 \\
\hline
\end{tabular}




\begin{tabular}{|c|c|c|c|}
\hline $\mathrm{H}$ & 2.84604900 & 2.43581200 & -4.04152400 \\
\hline $\mathrm{H}$ & 0.58166000 & 5.12960700 & -1.56942000 \\
\hline $\mathrm{H}$ & 1.85446900 & 4.68293000 & -3.65557200 \\
\hline $\mathrm{C}$ & 2.16499300 & 1.05363700 & 1.69320700 \\
\hline $\mathrm{C}$ & 2.87935700 & 2.25406000 & 1.78026800 \\
\hline $\mathrm{C}$ & 2.21854500 & 0.14274800 & 2.75948000 \\
\hline $\mathrm{C}$ & 3.64173800 & 2.53520200 & 2.91602000 \\
\hline $\mathrm{H}$ & 2.84911300 & 2.96442400 & 0.96083100 \\
\hline $\mathrm{C}$ & 2.98834800 & 0.42168400 & 3.88585100 \\
\hline $\mathrm{H}$ & 1.66242600 & -0.78960600 & 2.69692400 \\
\hline $\mathrm{C}$ & 3.70109600 & 1.62102100 & 3.96778400 \\
\hline $\mathrm{H}$ & 4.19366000 & 3.46921300 & 2.97400000 \\
\hline $\mathrm{H}$ & 3.03046500 & -0.29450200 & 4.70155600 \\
\hline $\mathrm{H}$ & 4.29769900 & 1.84088700 & 4.84837600 \\
\hline $\mathrm{P}$ & 1.12892900 & 0.58520600 & 0.25436000 \\
\hline $\mathrm{Pd}$ & -1.11729300 & -0.01251100 & 0.67748900 \\
\hline $\mathrm{O}$ & -0.39786900 & -0.51181100 & -2.36589100 \\
\hline $\mathrm{O}$ & -0.01023700 & -3.90765000 & 0.86268100 \\
\hline $\mathrm{C}$ & -0.55533700 & -4.95751600 & 1.64896000 \\
\hline $\mathrm{H}$ & 0.26677800 & -5.32427500 & 2.26496400 \\
\hline $\mathrm{H}$ & -1.36247200 & -4.59141000 & 2.29546400 \\
\hline $\mathrm{H}$ & -0.93508000 & -5.77277000 & 1.02086500 \\
\hline $\mathrm{C}$ & -1.18878100 & 0.49573800 & -3.01196500 \\
\hline $\mathrm{H}$ & -1.86847600 & 0.97449300 & -2.30046600 \\
\hline $\mathrm{H}$ & -0.46898200 & 1.22519300 & -3.38286000 \\
\hline $\mathrm{H}$ & -1.75110400 & 0.07075000 & -3.85088000 \\
\hline $\mathrm{H}$ & -3.06551400 & -0.66536300 & 2.78144200 \\
\hline $\mathrm{H}$ & -3.20368800 & -1.79713200 & 1.32302800 \\
\hline
\end{tabular}

$\begin{array}{llll}\mathrm{H} & 1.458189 & -0.952262 & 2.340698 \\ \mathrm{C} & 3.184999 & 2.472628 & 1.159793 \\ \mathrm{O} & 3.974323 & 3.386567 & 1.194653 \\ \mathrm{O} & 1.903327 & 2.529634 & 1.101476\end{array}$

C $\quad-4.478915 \quad 0.443083-1.000607$

C $\quad-3.645874-0.558327-0.452789$

C $\quad-4.172503-1.795432-0.076832$

C $\quad-5.539649-2.021911-0.261444$

C $\quad-6.363658-1.032152-0.805390$

C $\quad-5.835529 \quad 0.211055-1.177738$

C $\quad-2.278994-0.017463-0.384924$

$\mathrm{H} \quad-3.540407-2.562996 \quad 0.356982$

$\mathrm{H} \quad-5.966385-2.978648 \quad 0.025719$

H $\quad-7.423663-1.227591-0.939243$

$\mathrm{H} \quad-6.480994 \quad 0.977523-1.598940$

C $\quad-3.645752 \quad 1.665325-1.303919$

$\mathrm{H} \quad-3.650209 \quad 1.923803-2.372175$

$\mathrm{H} \quad-3.977995 \quad 2.559025-0.762066$

C $\quad-2.255141 \quad 1.255610-0.861253$

C $\quad-1.069266 \quad 2.133661-0.988333$

C $\quad-1.028170 \quad 3.387382-0.320256$

C $\quad-0.043048 \quad 1.842911-1.932496$

C $\quad 0.006888 \quad 4.290792-0.552765$

C $\quad 1.007161 \quad 2.747127-2.147132$

C $\quad 1.017330 \quad 3.951105-1.451947$

$\mathrm{H} \quad 0.068838 \quad 5.222186-0.006825$

$\mathrm{H} \quad 1.808160 \quad 2.510604-2.834953$

$\mathrm{H} \quad 1.846650 \quad 4.635880-1.593780$

C $\quad-0.206214-1.994427-0.989237$

C $\quad-1.085602-2.618693-1.884727$

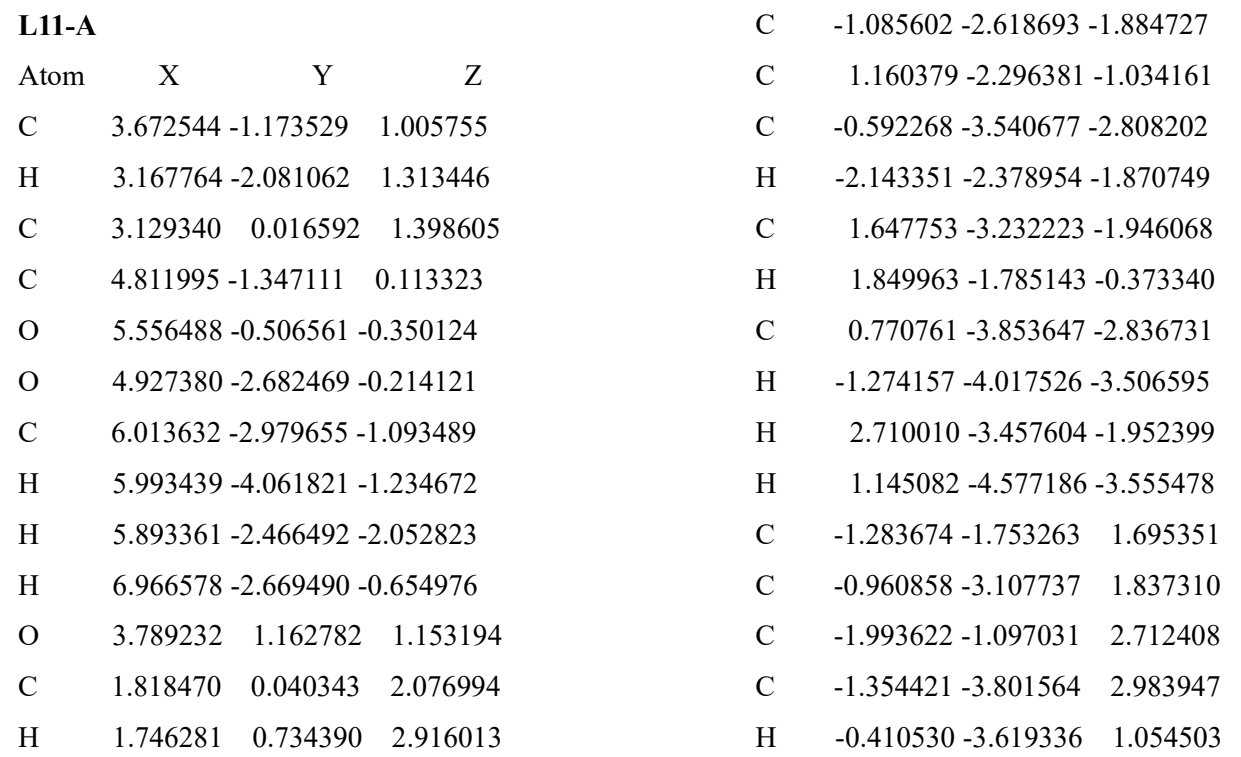




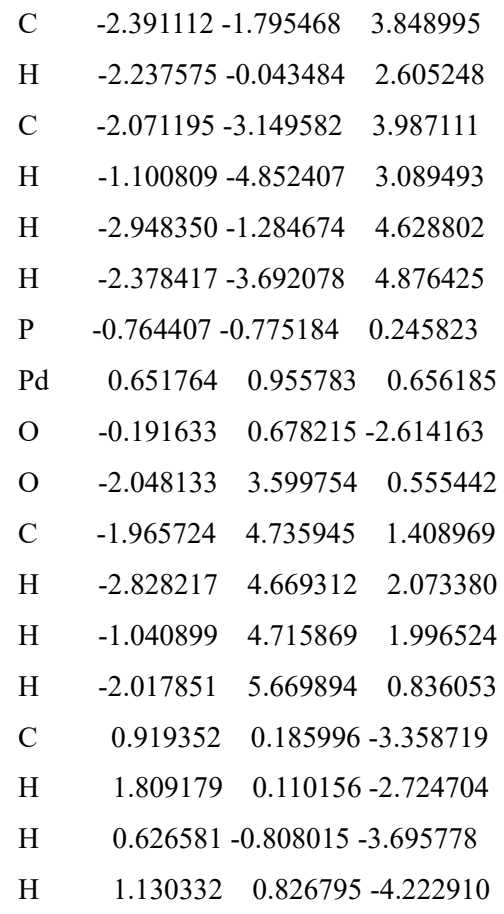

\section{L11-B}

\begin{tabular}{|c|c|c|}
\hline Atom & $\mathrm{X}$ & $\mathrm{Y}$ \\
\hline $\mathrm{C}$ & -4.240078 & $1.326563-1.247366$ \\
\hline $\mathrm{H}$ & -4.241134 & $2.275311-1.771775$ \\
\hline $\mathrm{C}$ & -3.165880 & $0.494798-1.403846$ \\
\hline $\mathrm{C}$ & -5.374699 & $1.021657-0.407282$ \\
\hline $\mathrm{O}$ & -5.524400 & $0.080361 \quad 0.364544$ \\
\hline $\mathrm{O}$ & -6.350410 & $1.983885-0.543505$ \\
\hline $\mathrm{C}$ & -7.498355 & $1.786529 \quad 0.276250$ \\
\hline $\mathrm{H}$ & -8.165365 & $2.624149 \quad 0.061215$ \\
\hline $\mathrm{H}$ & -7.993699 & $0.838593 \quad 0.042564$ \\
\hline $\mathrm{H}$ & -7.230755 & $1.779064 \quad 1.338289$ \\
\hline $\mathrm{O}$ & $-3.001498-$ & $0.713477-0.895389$ \\
\hline $\mathrm{C}$ & -1.872120 & $0.848113-2.080572$ \\
\hline $\mathrm{H}$ & -1.503236 & $1.869452-1.990524$ \\
\hline $\mathrm{H}$ & -1.749199 & $0.426994-3.081532$ \\
\hline $\mathrm{C}$ & 2.377329 & $0.206660 \quad 3.277405$ \\
\hline $\mathrm{C}$ & 2.516079 & $0.754419 \quad 1.981487$ \\
\hline $\mathrm{C}$ & 3.424640 & $1.787157 \quad 1.741785$ \\
\hline $\mathrm{C}$ & 4.194964 & $2.260543 \quad 2.808236$ \\
\hline $\mathrm{C}$ & 4.058215 & $1.717823 \quad 4.089039$ \\
\hline $\mathrm{C}$ & 3.143210 & $0.684714 \quad 4.330989$ \\
\hline $\mathrm{C}$ & 1.577647 & $0.049699 \quad 1.092281$ \\
\hline $\mathrm{H}$ & 3.526415 & $2.223911 \quad 0.754388$ \\
\hline $\mathrm{H}$ & 4.905610 & $3.064399 \quad 2.6380$ \\
\hline
\end{tabular}

$\mathrm{H} \quad 4.664693 \quad 2.101135 \quad 4.904584$

$\begin{array}{llll}\mathrm{H} & 3.038510 & 0.266769 & 5.328970\end{array}$

C $\quad 1.331263-0.881243 \quad 3.242942$

$\mathrm{H} \quad 1.728484-1.861334 \quad 3.541521$

H $\quad 0.474480-0.675329 \quad 3.897378$

C $\quad 0.893103-0.893534 \quad 1.793583$

C $\quad-0.109924-1.843252 \quad 1.257926$

$\begin{array}{lll}\text { C } & -1.458812-1.813948 & 1.706688\end{array}$

C $\quad 0.293108-2.904135 \quad 0.399790$

C $\quad-2.365695-2.801412 \quad 1.304393$

C $\quad-0.620753-3.881955-0.007864$

C $\quad-1.934163-3.815917 \quad 0.457416$

$\mathrm{H} \quad-3.405331-2.742728 \quad 1.594853$

$\mathrm{H} \quad-0.317327-4.682562-0.669899$

$\mathrm{H} \quad-2.647248-4.566451 \quad 0.130497$

C $\quad 2.530998-0.391405-1.641517$

C $\quad 3.823673-0.562341-1.127536$

C $\quad 2.243383-0.808854-2.948075$

C $\quad 4.816437-1.141596-1.917934$

H $\quad 4.049355-0.255399-0.111721$

C $\quad 3.241161-1.379315-3.738832$

H $\quad 1.232958-0.698253-3.332458$

C $\quad 4.527971-1.548217-3.223591$

H $\quad 5.815704-1.276553-1.513809$

H $\quad 3.011547-1.700400-4.750743$

H $\quad 5.303767-1.999176-3.835778$

C $\quad 1.340838 \quad 2.140003-0.876538$

C $\quad 2.292734 \quad 2.719940-1.722791$

C $\quad 0.452401 \quad 2.960551-0.164922$

C $\quad 2.363807 \quad 4.109360-1.844311$

$\mathrm{H} \quad 2.980126 \quad 2.090768-2.278751$

C $\quad 0.532491 \quad 4.345748-0.283163$

$\begin{array}{lllll}\mathrm{H} & -0.298137 & 2.507980 & 0.477814\end{array}$

C $\quad 1.489146 \quad 4.922601-1.123252$

$\mathrm{H} \quad 3.104539 \quad 4.554414-2.502575$

$\begin{array}{llll}\mathrm{H} & -0.154559 & 4.974779 & 0.275075\end{array}$

$\mathrm{H} \quad 1.547499 \quad 6.002962-1.218705$

P $\quad 1.180423 \quad 0.335022-0.654114$

Pd $\quad-0.932665-0.481291-0.830447$

$\begin{array}{lll}\text { O } & 1.606947-2.897684 & 0.048699\end{array}$

O $\quad-1.783562-0.7662892 .497660$

C $\quad 2.028423-3.757969-1.001211$

H $\quad 1.427452-3.597638-1.903279$

H $\quad 3.064323-3.486280-1.204383$ 


$$
\begin{aligned}
& \text { H } \quad 1.971183-4.811334-0.700447 \\
& \begin{array}{llll}
\text { C } & -3.179871 & -0.464294 & 2.660871
\end{array} \\
& \mathrm{H} \quad-3.205274 \quad 0.505736 \quad 3.159041 \\
& \text { H } \quad-3.688431-0.406739 \quad 1.693592 \\
& \text { H } \quad-3.663354-1.211489 \quad 3.301935
\end{aligned}
$$

\begin{tabular}{|c|c|c|c|}
\hline Atom & $\mathrm{X}$ & Y & $Z$ \\
\hline $\mathrm{C}$ & $4.387232-$ & -2.576096 & .107430 \\
\hline $\mathrm{H}$ & 4.775216 & -3.272381 & 0.842575 \\
\hline $\mathrm{C}$ & $3.049510-$ & -2.300622 & 0.136878 \\
\hline $\mathrm{C}$ & $5.316975-$ & (-2.042052 & -0.861682 \\
\hline $\mathrm{O}$ & $5.103951-$ & $-1.231788-$ & -1.755942 \\
\hline $\mathrm{O}$ & $6.572532-$ & $-2.568823-$ & -0.667106 \\
\hline $\mathrm{C}$ & $7.562945-$ & $-2.095413-$ & -1.576306 \\
\hline $\mathrm{H}$ & $7.676962-$ & $-1.008704-$ & -1.505936 \\
\hline $\mathrm{H}$ & $7.302458-$ & -2.34561 & -2.609715 \\
\hline $\mathrm{H}$ & $8.491733-$ & $-2.592732-$ & -1.289457 \\
\hline $\mathrm{O}$ & $2.375697-$ & - & -0.659657 \\
\hline $\mathrm{C}$ & -1.203512 & 4.271655 & 0.694902 \\
\hline $\mathrm{C}$ & -1.352434 & 3.262138 & -0.280663 \\
\hline $\mathrm{C}$ & -2.163681 & 3.484544 & -1.397603 \\
\hline $\mathrm{C}$ & -2.837635 & 4.703318 & -1.509562 \\
\hline $\mathrm{C}$ & -2.708526 & 5.689495 & -0.527111 \\
\hline $\mathrm{C}$ & -1.882719 & 5.477359 & 0.583132 \\
\hline $\mathrm{C}$ & -0.511308 & 2.107821 & 0.115649 \\
\hline $\mathrm{H}$ & -2.269487 & 2.730697 & -2.168511 \\
\hline $\mathrm{H}$ & -3.469416 & 4.884246 & -2.374567 \\
\hline $\mathrm{H}$ & -3.242300 & 6.629816 & -0.631358 \\
\hline $\mathrm{H}$ & -1.766542 & 6.251033 & 1.338006 \\
\hline $\mathrm{C}$ & -0.221828 & 3.804866 & 1.735325 \\
\hline $\mathrm{H}$ & -0.641496 & 3.759832 & 2.747362 \\
\hline $\mathrm{H}$ & 0.663126 & 4.453590 & 1.791587 \\
\hline $\mathrm{C}$ & 0.170943 & 2.421165 & 1.254820 \\
\hline $\mathrm{C}$ & 1.239937 & 1.652874 & 1.913682 \\
\hline $\mathrm{C}$ & 2.424029 & 1.333434 & 1.205603 \\
\hline $\mathrm{C}$ & 1.144554 & 1.282813 & 3.266768 \\
\hline $\mathrm{C}$ & 3.455565 & 0.616888 & 1.830300 \\
\hline $\mathrm{C}$ & 2.182663 & 0.598205 & 3.906022 \\
\hline $\mathrm{C}$ & 3.320381 & 0.262689 & 3.167230 \\
\hline $\mathrm{H}$ & 4.331016 & 0.316005 & 1.271172 \\
\hline $\mathrm{H}$ & 2.108421 & 0.309759 & 4.946962 \\
\hline $\mathrm{H}$ & \multicolumn{2}{|c|}{$4.119490-0.293199$} & 3.649146 \\
\hline 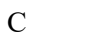 & -2.029879 & $0.111062-$ & 329314 \\
\hline
\end{tabular}

\section{L11-B0}

$\begin{array}{lll}\text { C } & -3.180082 & 0.624519-0.715893\end{array}$

C $\quad-2.179143-0.791175-2.392989$

C $\quad-4.447776 \quad 0.276821-1.182483$

$\mathrm{H} \quad-3.089134 \quad 1.313351 \quad 0.115903$

C $\quad-3.447980-1.155200-2.841554$

H $\quad-1.301542-1.199476-2.883671$

C $\quad-4.587621-0.616613-2.242712$

H $\quad-5.328398 \quad 0.690990-0.700634$

H $\quad-3.544770-1.858068-3.664124$

H $\quad-5.576043-0.908668-2.583555$

C $\quad 0.588100 \quad 0.847921-2.264024$

C $\quad 1.182478-0.219857-2.950428$

C $\quad 0.737353 \quad 2.150831-2.760976$

C $\quad 1.898542 \quad 0.010505-4.125373$

H $\quad 1.138663-1.220349-2.539637$

C $\quad 1.452735 \quad 2.375423-3.935930$

$\mathrm{H} \quad 0.315319 \quad 2.991882-2.225918$

C $\quad 2.032925 \quad 1.305996-4.622644$

H $\quad 2.374712-0.823330-4.631916$

$\mathrm{H} \quad 1.562820 \quad 3.389521-4.310373$

$\mathrm{H} \quad 2.599704 \quad 1.485318-5.531981$

P $\quad-0.339235 \quad 0.499306-0.719276$

$\mathrm{Pd} \quad 0.722272-1.307688 \quad 0.604092$

C $\quad-1.155185-1.290643 \quad 2.038664$

O $\quad 2.481776 \quad 1.785821-0.062940$

$\begin{array}{llll}\text { O } & -0.048821 & 1.590174 & 3.869505\end{array}$

$\begin{array}{llll}\text { C } & -0.225776 & 1.224257 & 5.228135\end{array}$

$\begin{array}{llll}\mathrm{H} & -0.168801 & 0.136309 & 5.360001\end{array}$

$\begin{array}{llll}\mathrm{H} & -1.224122 & 1.569011 & 5.502395\end{array}$

$\begin{array}{llll}\mathrm{H} & 0.517758 & 1.706578 & 5.875029\end{array}$

C $\quad 3.626342 \quad 1.470268-0.868367$

$\mathrm{H} \quad 3.438724 \quad 1.959421-1.823667$

$\mathrm{H} \quad 3.719482 \quad 0.394884-1.020813$

$\mathrm{H} \quad 4.535985 \quad 1.881355-0.413672$

C $\quad 2.076811-2.808826 \quad 1.151448$

$\mathrm{H} \quad 1.578881-3.740315 \quad 0.869993$

$\mathrm{H} \quad 2.414408-2.805254 \quad 2.187103$

$\begin{array}{lll}\text { C } & -0.042083-1.860489 & 2.633325\end{array}$

$\mathrm{H} \quad 0.027720-2.939790 \quad 2.715827$

$\mathrm{H} \quad 0.614466-1.280825 \quad 3.270706$

$\mathrm{H} \quad-1.354683-0.233661 \quad 2.203026$

$\begin{array}{llll}\text { C } & -2.206493 & -2.098657 & 1.442394\end{array}$

C $\quad-3.478048-1.678649 \quad 1.296826$

$\mathrm{H} \quad-1.924694-3.105015 \quad 1.139457$ 


$$
\begin{aligned}
& \mathrm{H} \quad-3.737568-0.691198 \quad 1.672810 \\
& \text { C } \quad-4.571431-2.422156 \quad 0.675121 \\
& \text { C } \quad-4.345962-3.509830-0.187054 \\
& \text { C } \quad-5.896867-2.007265 \quad 0.889005 \\
& \text { C } \quad-5.409420-4.161796-0.802469 \\
& \mathrm{H} \quad-3.328703-3.817464-0.406841 \\
& \text { C } \quad-6.962671-2.659139 \quad 0.273563 \\
& \text { H } \quad-6.084838-1.159584 \quad 1.543410 \\
& \text { C } \quad-6.723168-3.740442-0.576436 \\
& \text { H } \quad-5.213823-4.993548-1.473550 \\
& \text { H } \quad-7.979515-2.321485 \quad 0.453672 \\
& \text { H } \quad-7.551062-4.247007-1.064112
\end{aligned}
$$

$$
\begin{aligned}
& \text { L11-C } \\
& \begin{array}{llll}
\text { Atom } & \mathrm{X} & \mathrm{Y} & \mathrm{Z}
\end{array} \\
& \text { C } \quad 4.379898 \quad 2.974821-0.482580 \\
& \mathrm{H} \quad 4.842177 \quad 3.637885-1.203383 \\
& \text { C } \quad 3.043965 \quad 2.666683-0.622446 \\
& \begin{array}{llll}
\text { C } & 5.216478 & 2.517614 & 0.597424
\end{array} \\
& \begin{array}{llll}
\mathrm{O} & 4.942373 & 1.768653 & 1.534989
\end{array} \\
& \begin{array}{lllll}
\text { O } & 6.485066 & 3.036765 & 0.475874
\end{array} \\
& \begin{array}{llll}
\text { C } & 7.397969 & 2.632217 & 1.491662
\end{array} \\
& \begin{array}{llll}
\mathrm{H} & 7.526745 & 1.544596 & 1.498691
\end{array} \\
& \begin{array}{llll}
\mathrm{H} & 7.050947 & 2.941456 & 2.482813
\end{array} \\
& \begin{array}{llll}
\mathrm{H} & 8.344121 & 3.122310 & 1.252753
\end{array} \\
& \begin{array}{lllll}
\mathrm{O} & 2.384456 & 1.929918 & 0.207771
\end{array} \\
& \text { C } \quad-0.977665-4.715127 \quad 0.731197 \\
& \text { C } \quad-1.628396-3.467084 \quad 0.659510 \\
& \text { C } \quad-2.997243-3.368661 \quad 0.917572 \\
& \text { C } \quad-3.703149-4.530282 \quad 1.240336 \\
& \begin{array}{llll}
\text { C } & -3.056641 & -5.768406 & 1.307474
\end{array} \\
& \begin{array}{llll}
\text { C } & -1.683542 & -5.866858 & 1.052187
\end{array} \\
& \begin{array}{llll}
\text { C } & -0.624979-2.440737 & 0.306406
\end{array} \\
& \text { H } \quad-3.509012-2.414881 \quad 0.872038 \\
& \text { H } \quad-4.768692-4.468433 \quad 1.442756 \\
& \text { H } \quad-3.623318-6.659939 \quad 1.560606 \\
& \text { H } \quad-1.181502-6.829562 \quad 1.107020 \\
& \text { C } \quad 0.479568-4.519320 \quad 0.417394 \\
& \mathrm{H} \quad 0.817520-5.103660-0.443373 \\
& \mathrm{H} \quad 1.131323-4.794354 \quad 1.259023 \\
& \text { C } \quad 0.598172-3.025304 \quad 0.145980 \\
& \text { C } \quad 1.911021-2.440681-0.184541 \\
& \text { C } \quad 2.500565-1.401364 \quad 0.565829 \\
& \text { C } \quad 2.669513-2.976880-1.253026
\end{aligned}
$$

$$
\begin{aligned}
& \text { C } \quad 3.803604-0.958157 \quad 0.326071 \\
& \text { C } \quad 3.966516-2.533896-1.516026 \\
& \text { C } \quad 4.521852-1.537134-0.712313 \\
& \mathrm{H} \quad 4.221454-0.130785 \quad 0.886839 \\
& \text { H } \quad 4.539571-2.945600-2.336949 \\
& \text { H } \quad 5.527351-1.183084-0.919330 \\
& \text { C } \quad-2.387337-0.679284-1.100549 \\
& \text { C } \quad-2.077028-1.076914-2.410409 \\
& \text { C } \quad-3.682854-0.240982-0.805584 \\
& \text { C } \quad-3.048412-1.033506-3.408133 \\
& \text { H } \quad-1.072015-1.420092-2.643478 \\
& \text { C } \quad-4.653765-0.197605-1.807139 \\
& \mathrm{H} \quad \begin{array}{llll}
-3.935413 & 0.077125 & 0.199346
\end{array} \\
& \text { C } \quad-4.339070-0.587911-3.109118 \\
& \text { H } \quad-2.798595-1.342904-4.418859 \\
& \text { H } \quad-5.654336 \quad 0.149670-1.566671 \\
& \mathrm{H} \quad-5.094732-0.547794-3.888307 \\
& \text { C } \quad-1.699855-0.159948 \quad 1.713437 \\
& \text { C } \quad \begin{array}{llll}
2.268756 & 1.120584 & 1.818150
\end{array} \\
& \text { C } \quad-1.545696-0.938242 \quad 2.868166 \\
& \begin{array}{llll}
\text { C } & -2.709931 & 1.597487 & 3.049754
\end{array} \\
& \text { H } \quad-2.356483 \quad 1.747203 \quad 0.939675 \\
& \text { C } \quad-1.976172-0.449620 \quad 4.102966 \\
& \text { H } \quad-1.087213-1.918092 \quad 2.805169 \\
& \begin{array}{llll}
\text { C } & -2.564158 & 0.812756 & 4.196593
\end{array} \\
& \mathrm{H} \quad \begin{array}{llll}
-3.158137 & 2.585313 & 3.106366
\end{array} \\
& \text { H } \quad-1.853148-1.060868 \quad 4.992560 \\
& \begin{array}{llll}
\mathrm{H} & -2.900978 & 1.186142 & 5.159498
\end{array} \\
& \mathrm{P} \quad-1.010858-0.684059 \quad 0.101574 \\
& \mathrm{Pd} \quad 0.769062 \quad 0.706153-0.154913 \\
& \text { C } \quad 0.130192 \quad 1.753068-1.815434 \\
& \text { O } \quad 1.696017-0.808701 \quad 1.520768 \\
& \text { O } \quad 2.033090-3.923779-2.010658 \\
& \text { C } \quad 2.739588-4.502361-3.094681 \\
& \mathrm{H} \quad 3.016244-3.747047-3.841103 \\
& \mathrm{H} \quad 2.055061-5.223150-3.545179 \\
& \mathrm{H} \quad 3.645024-5.021504-2.754893 \\
& \text { C } \quad 2.338768-0.076913 \quad 2.591168 \\
& \mathrm{H} \quad 1.522161 \quad 0.196635 \quad 3.260419 \\
& \begin{array}{llll}
\mathrm{H} & 2.845782 & 0.809309 & 2.205751
\end{array} \\
& \text { H } \quad 3.046632-0.737146 \quad 3.102382 \\
& \text { C } \quad 2.265341 \quad 3.274932-1.780104 \\
& \mathrm{H} \quad 1.642281 \quad 4.086468-1.377702 \\
& \mathrm{H} \quad 2.960592 \quad 3.738544-2.486791
\end{aligned}
$$




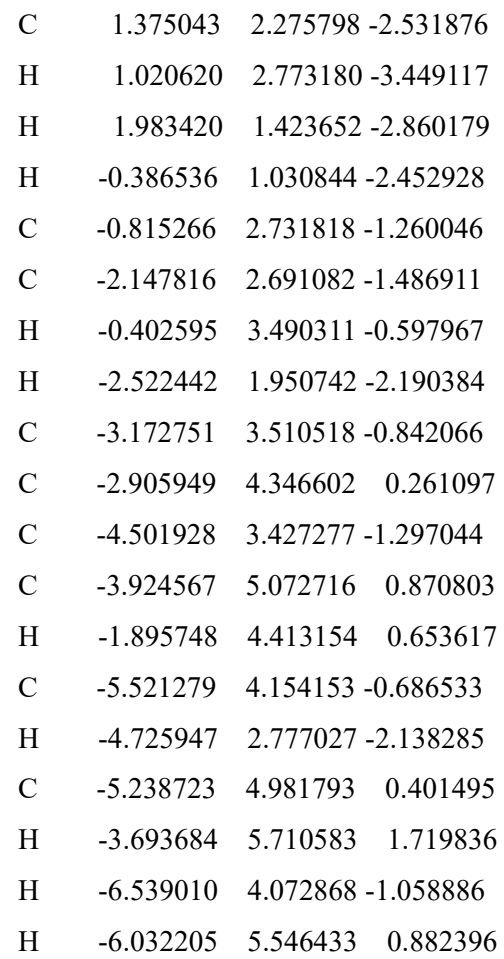

$$
\begin{aligned}
& \text { L11-D } \\
& \begin{array}{lccc}
\text { Atom } & \mathrm{X} & \mathrm{Y} & \mathrm{Z} \\
\mathrm{C} & 4.082712 & -0.464333 & -2.784884 \\
\mathrm{H} & 4.360491 & -0.751258 & -3.791063 \\
\mathrm{C} & 2.806277 & 0.019528 & -2.550628 \\
\mathrm{C} & 5.093569 & -0.585056 & -1.780548 \\
\mathrm{O} & 5.021990 & -0.248321 & -0.582536 \\
\mathrm{O} & 6.232726 & -1.147809 & -2.254867 \\
\mathrm{C} & 7.309991 & -1.267804 & -1.320765 \\
\mathrm{H} & 7.035790 & -1.921592 & -0.487420 \\
\mathrm{H} & 7.591851 & -0.289244 & -0.922327 \\
\mathrm{H} & 8.136422 & -1.702188 & -1.884888 \\
\mathrm{O} & 2.380673 & 0.404008 & -1.390603 \\
\mathrm{C} & -2.892244 & -4.366371 & -0.012719 \\
\mathrm{C} & -3.181764 & -3.000347 & 0.198435 \\
\mathrm{C} & -4.501276 & -2.587831 & 0.404552 \\
\mathrm{C} & -5.518929 & -3.545378 & 0.371021 \\
\mathrm{C} & -5.230983 & -4.892598 & 0.135260 \\
\mathrm{C} & -3.908256 & -5.311013 & -0.054871 \\
\mathrm{C} & -1.904290 & -2.252526 & 0.186327 \\
\mathrm{H} & -4.738907 & -1.547001 & 0.589999 \\
\mathrm{H} & -6.547548 & -3.234568 & 0.530545 \\
\mathrm{H} & -6.036324 & -5.621081 & 0.110029 \\
\mathrm{H} & -3.682453 & -6.361397 & -0.220728
\end{array}
\end{aligned}
$$

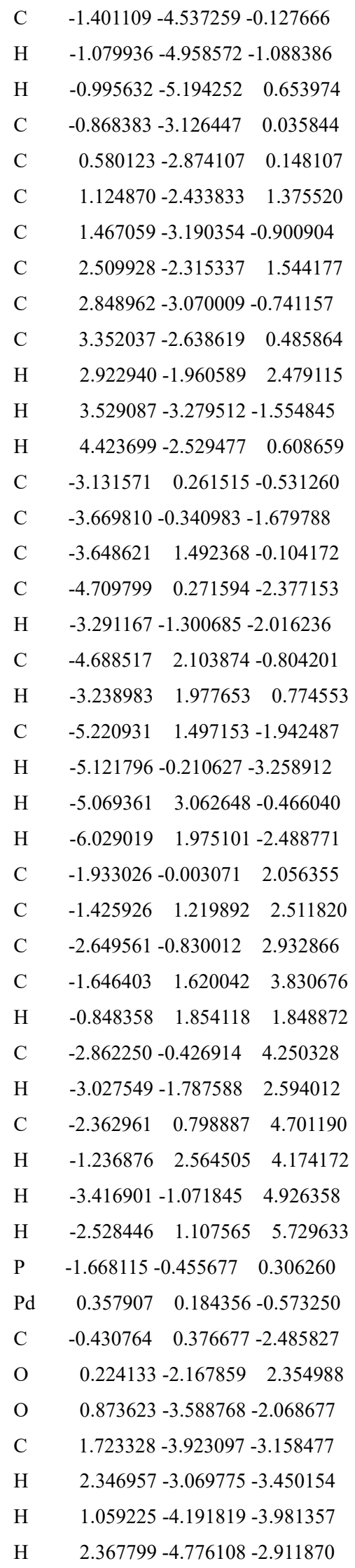




\begin{tabular}{|c|c|c|}
\hline $\mathrm{C}$ & $0.694089-1.646895$ & 3.594248 \\
\hline $\mathrm{H}$ & $-0.201439-1.454599$ & 4.184285 \\
\hline $\mathrm{H}$ & $1.237955-0.713986$ & 3.442186 \\
\hline $\mathrm{H}$ & $1.330160-2.378140$ & 4.109046 \\
\hline $\mathrm{C}$ & $1.856845 \quad 0.159385$ & $5-3.722253$ \\
\hline $\mathrm{H}$ & $1.793023 \quad 1.228220$ & $0-3.969635$ \\
\hline $\mathrm{H}$ & $2.286343-0.336633-$ & -4.598216 \\
\hline $\mathrm{C}$ & $0.444972-0.381162-$ & -3.473121 \\
\hline $\mathrm{H}$ & $-0.084970-0.353912$ & -4.438821 \\
\hline $\mathrm{H}$ & $0.484885-1.433840-$ & -3.174608 \\
\hline $\mathrm{H}$ & $-1.439479-0.028532$ & -2.520196 \\
\hline $\mathrm{C}$ & $-0.443129 \quad 1.844702$ & -2.475697 \\
\hline $\mathrm{C}$ & $-1.582478 \quad 2.576515$ & -2.430773 \\
\hline $\mathrm{H}$ & $0.517418 \quad 2.352751$ & $1-2.413640$ \\
\hline $\mathrm{H}$ & $-2.529352 \quad 2.069343$ & -2.592208 \\
\hline $\mathrm{C}$ & $-1.662934 \quad 4.008025$ & -2.157422 \\
\hline $\mathrm{C}$ & $-0.658554 \quad 4.681670$ & -1.434939 \\
\hline $\mathrm{C}$ & $-2.794055 \quad 4.736123$ & -2.569929 \\
\hline $\mathrm{C}$ & $-0.770325 \quad 6.044005$ & -1.171806 \\
\hline $\mathrm{H}$ & $0.184285 \quad 4.124417$ & $7-1.037551$ \\
\hline $\mathrm{C}$ & $-2.902419 \quad 6.099205$ & -2.306879 \\
\hline $\mathrm{H}$ & $-3.585484 \quad 4.218553$ & -3.106140 \\
\hline $\mathrm{C}$ & $-1.887197 \quad 6.760532$ & -1.611413 \\
\hline $\mathrm{H}$ & $0.009196 \quad 6.544018$ & -0.603932 \\
\hline $\mathrm{H}$ & $-3.779714 \quad 6.646712$ & -2.641233 \\
\hline $\mathrm{H}$ & $-1.973112 \quad 7.822545$ & -1.399068 \\
\hline $\mathrm{Li}$ & $3.476631 \quad 0.508106$ & 0.143983 \\
\hline $\mathrm{S}$ & $2.068455 \quad 2.058236$ & 1.664983 \\
\hline $\mathrm{O}$ & $3.384363 \quad 2.278491$ & 1.004317 \\
\hline $\mathrm{O}$ & 1.6099820 .641319 & 1.417230 \\
\hline $\mathrm{O}$ & $1.050895 \quad 3.102440$ & 1.515623 \\
\hline $\mathrm{C}$ & $2.495180 \quad 1.998878$ & 3.472549 \\
\hline $\mathrm{F}$ & $3.354356 \quad 0.990475$ & 3.697672 \\
\hline $\mathrm{F}$ & $1.394863 \quad 1.783465$ & 4.208383 \\
\hline $\mathrm{F}$ & $3.057691 \quad 3.144511$ & 3.856446 \\
\hline
\end{tabular}

\section{L11-Ea}

\begin{tabular}{|c|c|c|}
\hline tom & X & \\
\hline $\mathrm{O}$ & $-4.329906-4.611440$ & 2.40505 \\
\hline $\mathrm{O}$ & $-4.825277-2.835108$ & 1.1 \\
\hline $\mathrm{C}$ & 5.961 & 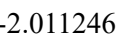 \\
\hline $\mathrm{H}$ & 5.69 & \\
\hline $\mathrm{C}$ & $7.303060-2.55085$ & 651 \\
\hline $\mathrm{H}$ & $8.074871-2.461826-$ & -2.41 \\
\hline
\end{tabular}

C $\quad 7.652243-2.783751-0.320792$

H $\quad 8.696321-2.876165-0.037220$

C $\quad 6.647460-2.903407 \quad 0.646421$

$\mathrm{H} \quad 6.912046-3.089262 \quad 1.683630$

C $\quad 5.309191-2.782729 \quad 0.288792$

$\mathrm{H} \quad 4.543427-2.843447 \quad 1.055810$

C $\quad 4.941500-2.553880-1.051370$

C $\quad 1.121821-2.424002-1.078210$

H $\quad 0.929669-2.174211-2.124475$

C $\quad-0.084355-2.817554-0.283340$

H $\quad-0.672334-1.923589-0.079616$

$\mathrm{H} \quad 0.207938-3.207176 \quad 0.697059$

C $\quad-1.044063-3.799847-1.001507$

C $\quad-2.928860-4.202823 \quad 0.592909$

$\mathrm{H} \quad-2.377086-5.064735 \quad 0.947189$

$\begin{array}{llll}\text { C } & -4.082879 & -3.809739 & 1.328431\end{array}$

$\begin{array}{lll}\text { C } & -5.473378-4.254821 & 3.183985\end{array}$

$\mathrm{H} \quad-5.537108-5.008088 \quad 3.971703$

$\mathrm{H} \quad-6.382267-4.260304 \quad 2.575782$

$\mathrm{H} \quad-5.358624-3.258080 \quad 3.621969$

C $\quad 3.550881-2.406219-1.466809$

H $\quad 3.390214-2.085834-2.495541$

C $\quad 2.441808-2.835949-0.736916$

$\mathrm{H} \quad 2.583429-3.341919 \quad 0.215630$

C $\quad-2.443271-3.464049-0.483024$

O $\quad-2.976785-2.433975-1.014510$

$\begin{array}{llll}\text { C } & 1.746414 & 3.965196 & 2.352675\end{array}$

$\begin{array}{llll}\text { C } & 0.704550 & 3.096399 & 1.961743\end{array}$

$\begin{array}{llll}\text { C } & -0.592577 & 3.264265 & 2.447120\end{array}$

$\begin{array}{lllll}\text { C } & -0.834926 & 4.316179 & 3.334184\end{array}$

$\begin{array}{llll}\text { C } & 0.196350 & 5.176247 & 3.726277\end{array}$

$\begin{array}{llll}\text { C } & 1.498002 & 5.005599 & 3.237140\end{array}$

$\begin{array}{llll}\text { C } & 1.268314 & 2.110002 & 1.028582\end{array}$

$\begin{array}{llll}\mathrm{H} & -1.393888 & 2.597254 & 2.148267\end{array}$

$\begin{array}{llll}\mathrm{H} & -1.837789 & 4.465968 & 3.722568\end{array}$

$\mathrm{H} \quad-0.014574 \quad 5.987189 \quad 4.417376$

$\begin{array}{llll}\mathrm{H} & 2.293271 & 5.679865 & 3.544573\end{array}$

$\begin{array}{llll}\text { C } & 3.024131 & 3.545839 & 1.663208\end{array}$

$\begin{array}{llll}\mathrm{H} & 3.430360 & 4.334760 & 1.014452\end{array}$

$\begin{array}{llll}\mathrm{H} & 3.820863 & 3.274259 & 2.366012\end{array}$

$\begin{array}{llll}\text { C } & 2.592138 & 2.344802 & 0.840567\end{array}$

C $\quad 3.506457 \quad 1.629503-0.080835$

$\begin{array}{llll}\text { C } & 4.719564 & 1.063314 & 0.404955\end{array}$

C $\quad 3.343961 \quad 1.740181-1.496055$ 


\begin{tabular}{|c|c|c|}
\hline$C$ & 5.719238 & $0.631897-0$ \\
\hline $\mathrm{C}$ & 4.340360 & $1.270029-2.370801$ \\
\hline$\Gamma$ & 5.516692 & $0.749750-1.843607$ \\
\hline $\mathrm{H}$ & 6.630209 & $0.180937-0.099036$ \\
\hline$\pi$ & 4.214392 & $1.361413-3.442033$ \\
\hline-1 & 6.296754 & $0.412448-2.517475$ \\
\hline $\mathrm{C}$ & -0.736063 & $1.378966-0.972934$ \\
\hline $\mathrm{C}$ & -0.856932 & $2.759143-1.187387$ \\
\hline $\mathrm{C}$ & -1.530152 & $0.483616-1.707075$ \\
\hline $\mathrm{C}$ & -1.771814 & $3.236641-2.125976$ \\
\hline $\mathrm{H}$ & -0.243867 & $3.453827-0.624551$ \\
\hline $\mathrm{C}$ & -2.444467 & $0.971416-2.635592$ \\
\hline $\mathrm{H}$ & $-1.507210-$ & $0.586225-1.524538$ \\
\hline $\mathrm{C}$ & -2.567978 & $2.345184-2.847889$ \\
\hline $\mathrm{H}$ & -1.876313 & $4.307419-2.276269$ \\
\hline $\mathrm{H}$ & -3.087219 & $0.275134-3.159844$ \\
\hline $\mathrm{H}$ & -3.306633 & $2.718130-3.549291$ \\
\hline $\mathrm{C}$ & $-0.538057-($ & $0.099381 \quad 1.534050$ \\
\hline $\mathrm{C}$ & $-1.937883-($ & $0.126477 \quad 1.502545$ \\
\hline $\mathrm{C}$ & 0.156460 & $-0.791558 \quad 2.540181$ \\
\hline $\mathrm{C}$ & $-2.637732-($ & $0.863562 \quad 2.460319$ \\
\hline $\mathrm{H}$ & -2.501121 & $0.392427 \quad 0.736810$ \\
\hline $\mathrm{C}$ & $-0.548697-$ & $1.516319 \quad 3.496113$ \\
\hline $\mathrm{H}$ & 1.244055 & $-0.771136 \quad 2.557713$ \\
\hline $\mathrm{C}$ & $-1.946681-$ & $1.565865 \quad 3.446134$ \\
\hline $\mathrm{H}$ & $-3.719095-$ & $0.906889 \quad 2.400211$ \\
\hline $\mathrm{H}$ & $-0.011088-$ & $2.056769 \quad 4.270318$ \\
\hline $\mathrm{H}$ & $-2.493897-$ & $2.160863 \quad 4.171368$ \\
\hline $\mathrm{P}$ & 0.441712 & $0.714615 \quad 0.235523$ \\
\hline $\mathrm{Pd}$ & $2.197444-$ & $0.595756-0.569078$ \\
\hline $\mathrm{O}$ & 4.810896 & $0.993931 \quad 1.758063$ \\
\hline $\mathrm{O}$ & 2.233052 & $2.391165-1.910719$ \\
\hline $\mathrm{C}$ & 1.826277 & $2.255904-3.271273$ \\
\hline $\mathrm{H}$ & 1.754737 & $1.197180-3.545842$ \\
\hline $\mathrm{H}$ & 0.839025 & $2.712516-3.324761$ \\
\hline $\mathrm{H}$ & 2.518367 & $2.772760-3.945799$ \\
\hline $\mathrm{C}$ & 6.025312 & $0.517666 \quad 2.328969$ \\
\hline $\mathrm{H}$ & 5.880348 & $0.564798 \quad 3.408720$ \\
\hline $\mathrm{H}$ & 6.225375 & $-0.515184 \quad 2.025717$ \\
\hline $\mathrm{H}$ & 6.871405 & $1.153993 \quad 2.042077$ \\
\hline $\mathrm{Li}$ & -4.559349 & $1.650901-0.364789$ \\
\hline S & -5.985005 & $0.447678-0.431359$ \\
\hline $\mathrm{O}$ & $-6.418379-$ & $-0.906024-0.882256$ \\
\hline $\mathrm{O}$ & -4.521192 & $0.404438-0.109350$ \\
\hline
\end{tabular}

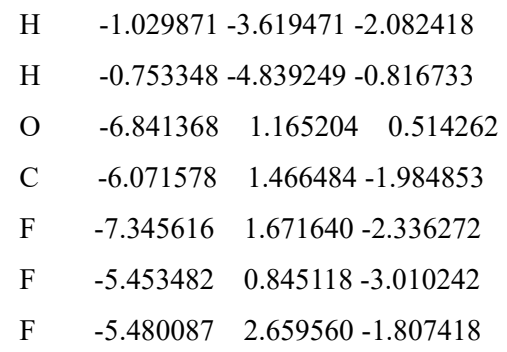

\section{L11-Eb}

\begin{tabular}{|c|c|c|}
\hline Atom & $\mathrm{X}$ & Z \\
\hline $\mathrm{C}$ & $-2.681810-3.317710$ & 3.040259 \\
\hline $\mathrm{C}$ & $-1.558014-3.160285$ & 2.199842 \\
\hline $\mathrm{C}$ & $-0.380721-3.871987$ & 2.434125 \\
\hline $\mathrm{C}$ & $-0.344740-4.753885$ & 3.517474 \\
\hline $\mathrm{C}$ & $-1.458640-4.915295$ & 4.347923 \\
\hline $\mathrm{C}$ & $-2.637016-4.194097$ & 4.115472 \\
\hline $\mathrm{C}$ & $-1.905694-2.174422$ & 1.165430 \\
\hline $\mathrm{H}$ & $0.490024-3.734474$ & 1.801697 \\
\hline $\mathrm{H}$ & $0.562603-5.314985$ & 3.719817 \\
\hline $\mathrm{H}$ & $-1.408038-5.603928$ & 5.186189 \\
\hline $\mathrm{H}$ & $-3.496417-4.321242$ & 4.768618 \\
\hline $\mathrm{C}$ & $-3.791002-2.412556$ & 2.556763 \\
\hline $\mathrm{H}$ & $-4.692413-2.968763$ & 2.262585 \\
\hline $\mathrm{H}$ & $-4.104426-1.681464$ & 3.311427 \\
\hline $\mathrm{C}$ & $-3.172106-1.723044$ & 1.355048 \\
\hline $\mathrm{C}$ & $-3.907059-0.758892$ & 0.502140 \\
\hline $\mathrm{C}$ & $-4.492882 \quad 0.409460$ & 1.069506 \\
\hline $\mathrm{C}$ & \multicolumn{2}{|c|}{$-4.287138-1.115616-0.827318$} \\
\hline $\mathrm{C}$ & $-5.404017 \quad 1.184941$ & 0.348588 \\
\hline $\mathrm{C}$ & \multicolumn{2}{|c|}{$-5.173991-0.311077-1.560068$} \\
\hline $\mathrm{C}$ & \multicolumn{2}{|c|}{$\begin{array}{lll}-5.732023 & 0.811026 & -0.954414\end{array}$} \\
\hline $\mathrm{H}$ & $-5.835733 \quad 2.081431$ & 0.771182 \\
\hline $\mathrm{H}$ & \multicolumn{2}{|c|}{$-5.454491-0.582210-2.569768$} \\
\hline $\mathrm{H}$ & \multicolumn{2}{|c|}{$-6.434254 \quad 1.420864-1.511237$} \\
\hline $\mathrm{C}$ & \multicolumn{2}{|c|}{$-0.651732-2.808359-1.408618$} \\
\hline $\mathrm{C}$ & \multicolumn{2}{|c|}{$-0.976348-4.147191-1.153378$} \\
\hline $\mathrm{C}$ & \multicolumn{2}{|c|}{$-0.181484-2.438182-2.676848$} \\
\hline $\mathrm{C}$ & \multicolumn{2}{|c|}{$-0.828182-5.102436-2.159564$} \\
\hline $\mathrm{H}$ & \multicolumn{2}{|c|}{$-1.348118-4.441478-0.178506$} \\
\hline $\mathrm{C}$ & \multicolumn{2}{|c|}{$-0.022354-3.398100-3.675092$} \\
\hline $\mathrm{H}$ & \multicolumn{2}{|c|}{$0.058999-1.398655-2.880205$} \\
\hline $\mathrm{C}$ & \multicolumn{2}{|c|}{$-0.350415-4.731376-3.418608$} \\
\hline $\mathrm{H}$ & \multicolumn{2}{|c|}{$-1.081770-6.138875-1.956909$} \\
\hline $\mathrm{H}$ & \multicolumn{2}{|c|}{$0.353189-3.105398-4.650996$} \\
\hline
\end{tabular}




\begin{tabular}{|c|c|c|c|}
\hline $\mathrm{H}$ & \multicolumn{3}{|c|}{$-0.231748-5.479174-4.197089$} \\
\hline $\mathrm{C}$ & \multicolumn{2}{|c|}{$0.742327-1.202433$} & 0.614685 \\
\hline C & \multicolumn{2}{|c|}{$1.947050-1.592574$} & 0.013397 \\
\hline $\mathrm{C}$ & \multicolumn{2}{|c|}{$0.761148-0.399869$} & 1.768130 \\
\hline $\mathrm{C}$ & \multicolumn{2}{|c|}{$3.160566-1.168793$} & 0.554637 \\
\hline $\mathrm{H}$ & \multicolumn{3}{|c|}{$1.938976-2.208947-0.879913$} \\
\hline - & 1.977173 & 0.022444 & 2.298316 \\
\hline $\mathrm{H}$ & $-0.174584-0$ & 0.089882 & 2.227229 \\
\hline 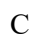 & $3.176677-($ & 0.353103 & 1.687977 \\
\hline$\Pi$ & $4.098637-$ & 1.444430 & 0.090753 \\
\hline $\mathrm{H}$ & 1.991681 & 0.665816 & 3.172648 \\
\hline $\mathrm{H}$ & $4.127345-($ & 0.000948 & 2.069922 \\
\hline $\mathrm{O}$ & 3.641825 & .083128 & 3.143876 \\
\hline O & 4.910190 & 2.736542 & 1.847767 \\
\hline $\mathrm{C}$ & -4.003065 & 4.382345 & 0.050127 \\
\hline $\mathrm{H}$ & -3.361970 & 4.481577 & 0.922527 \\
\hline$c$ & -5.235489 & 5.028042 & 0.015235 \\
\hline $\mathrm{H}$ & -5.557287 & 5.626578 & 0.862296 \\
\hline $\mathrm{C}$ & -6.050453 & $4.913822-$ & -1.114056 \\
\hline $\mathrm{H}$ & -7.011587 & $5.417886-$ & -1.146714 \\
\hline$C$ & -5.619275 & 4.154034 & -2.205589 \\
\hline $\mathrm{H}$ & -6.247442 & 4.065712 & -3.087272 \\
\hline 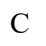 & -4.390793 & $3.502141-2$ & -2.167477 \\
\hline $\mathrm{H}$ & -4.082139 & 2.895165 & -3.012178 \\
\hline$c$ & -3.558710 & $3.607842-$ & -1.037906 \\
\hline$C$ & -2.268365 & $2.940211-0$ & -0.932784 \\
\hline$\Pi$ & -1.758589 & 3.063018 & 0.021119 \\
\hline $\mathrm{C}$ & -1.572092 & $2.307348-$ & -1.950149 \\
\hline $\mathrm{H}$ & -2.004205 & 2.262721 & -2.946970 \\
\hline$C$ & -0.390740 & $1.526124-$ & 1680080 \\
\hline $\mathrm{H}$ & 0.004515 & 1.013562 & -2.564775 \\
\hline$C_{1}$ & 0.661939 & 1.857939 & -0.666186 \\
\hline $\mathrm{H}$ & 1.298054 & $0.980415-$ & -0.545425 \\
\hline$\Pi$ & 0.234052 & 2.071936 & 0.317493 \\
\hline$C$ & 1.577331 & $3.034216-$ & -1.080010 \\
\hline $\mathrm{H}$ & 1.876272 & $2.932575-$ & -2.128397 \\
\hline 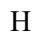 & 1.051280 & $3.987610-$ & -0.952074 \\
\hline $\mathrm{C}$ & 2.830610 & 3.586589 & 1.019517 \\
\hline $\mathrm{H}$ & 1.999846 & 4.228223 & 1.288594 \\
\hline $\mathrm{C}$ & 3.871759 & 3.415872 & 1.970745 \\
\hline $\mathrm{C}$ & 4.668021 & 3.957807 & 4.128236 \\
\hline$\Pi$ & 5.623337 & 4.337900 & 3.754040 \\
\hline $\mathrm{H}$ & 4.806576 & 2.913963 & 4.426937 \\
\hline $\mathrm{H}$ & 4.331694 & 4.553138 & 4.9799 \\
\hline
\end{tabular}

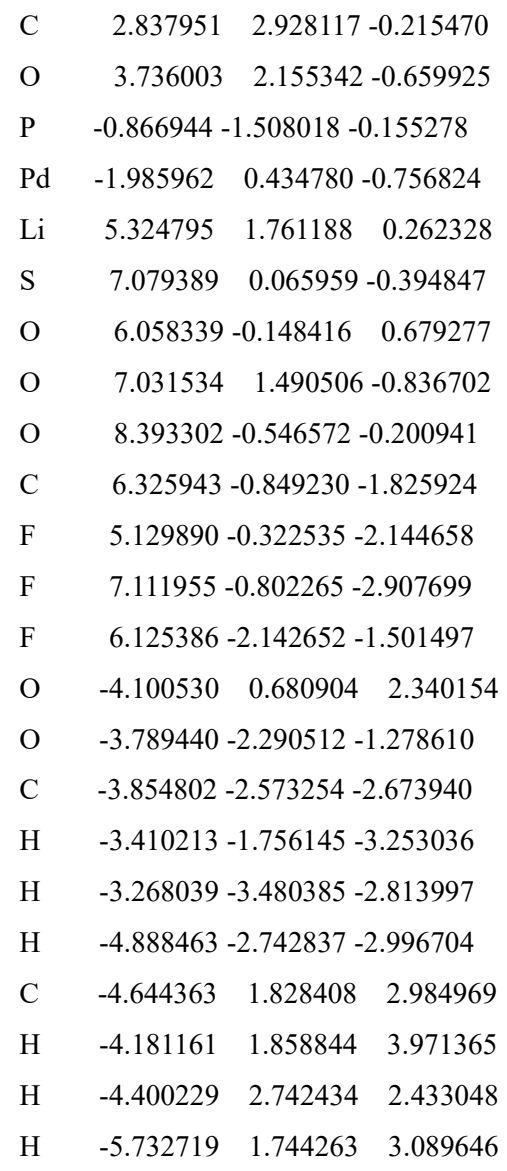

\section{L11-Fa}

$\begin{array}{lcccc}\text { Atom } & \mathrm{X} & \mathrm{Y} & \mathrm{Z} \\ \mathrm{O} & 4.165167 & 2.695339 & 2.150811 \\ \mathrm{O} & 5.149082 & 1.067724 & 0.953322 \\ \mathrm{C} & 1.816739 & 4.224617 & -0.861037 \\ \mathrm{H} & 2.531077 & 3.702510 & -1.493116 \\ \mathrm{C} & 1.531697 & 5.568676 & -1.098021 \\ \mathrm{H} & 2.034827 & 6.090743 & -1.908018 \\ \mathrm{C} & 0.604731 & 6.241411 & -0.300526 \\ \mathrm{H} & 0.381679 & 7.289527 & -0.478421 \\ \mathrm{C} & -0.031140 & 5.547336 & 0.735942 \\ \mathrm{H} & -0.754143 & 6.058876 & 1.366756 \\ \mathrm{C} & 0.249659 & 4.204396 & 0.967905 \\ \mathrm{H} & -0.276453 & 3.674665 & 1.756112 \\ \mathrm{C} & 1.185656 & 3.511684 & 0.174781 \\ \mathrm{C} & 2.107646 & 0.158213 & 1.856617 \\ \mathrm{H} & 2.382047 & -0.328533 & 0.919569 \\ \mathrm{C} & 1.545438 & -0.913446 & 2.813793 \\ \mathrm{H} & 0.766071 & -1.504109 & 2.334002 \\ \mathrm{H} & 1.097287 & -0.429554 & 3.689566\end{array}$




\begin{tabular}{|c|c|c|}
\hline $\mathrm{C}$ & $2.775003-1.769727$ & 3.205887 \\
\hline $\mathrm{C}$ & $3.469200 \quad 0.503625$ & 2.596109 \\
\hline $\mathrm{H}$ & $3.203141 \quad 0.959363$ & 3.557234 \\
\hline $\mathrm{C}$ & $4.359427 \quad 1.424769$ & 1.826669 \\
\hline $\mathrm{C}$ & $4.825108 \quad 3.686421$ & 1.333365 \\
\hline $\mathrm{H}$ & $4.553570 \quad 4.643606$ & 1.774899 \\
\hline $\mathrm{H}$ & $4.451623 \quad 3.621010$ & 0.310216 \\
\hline $\mathrm{H}$ & $5.906050 \quad 3.534123$ & 1.351628 \\
\hline $\mathrm{C}$ & $1.518325 \quad 2.098149$ & 0.376317 \\
\hline $\mathrm{H}$ & $2.254049 \quad 1.693306$ & -0.319348 \\
\hline $\mathrm{C}$ & $1.257577 \quad 1.349504$ & 1.543600 \\
\hline $\mathrm{H}$ & $0.803404 \quad 1.839169$ & 2.405653 \\
\hline $\mathrm{C}$ & $3.964518-0.917346$ & 2.803037 \\
\hline $\mathrm{O}$ & $5.075045-1.335973$ & 2.496647 \\
\hline $\mathrm{C}$ & $-5.606116-0.162498-0$ & 0.998106 \\
\hline $\mathrm{C}$ & $-4.752921-0.830092-0$ & 0.091258 \\
\hline $\mathrm{C}$ & $-5.279036-1.730985$ & 0.837918 \\
\hline $\mathrm{C}$ & $-6.657969-1.961866$ & 0.842521 \\
\hline $\mathrm{C}$ & $-7.499417-1.304486-0$ & 0.059497 \\
\hline $\mathrm{C}$ & $-6.973943-0.395959-0$ & 0.987624 \\
\hline $\mathrm{C}$ & $-3.372194-0.377484-0$ & 0.341064 \\
\hline $\mathrm{H}$ & $-4.635734-2.236833$ & 1.549189 \\
\hline $\mathrm{H}$ & $-7.079650-2.659944$ & 1.560480 \\
\hline $\mathrm{H}$ & $-8.568451-1.497042-0$ & 0.039559 \\
\hline $\mathrm{H}$ & $-7.6306670 .116198-$ & 686682 \\
\hline $\mathrm{C}$ & $-4.778111 \quad 0.751324-$ & -1.866060 \\
\hline $\mathrm{H}$ & $-4.837351 \quad 0.484420$ & -2.930897 \\
\hline $\mathrm{H}$ & $-5.073517 \quad 1.803755-$ & -1.787590 \\
\hline $\mathrm{C}$ & $-3.3687120 .543636-$ & -1.345425 \\
\hline $\mathrm{C}$ & $-2.200697 \quad 1.259006-$ & -1.898743 \\
\hline $\mathrm{C}$ & $-2.147834 \quad 2.672969-$ & -1.873277 \\
\hline $\mathrm{C}$ & $-1.141490 \quad 0.561494$ & -2.535187 \\
\hline $\mathrm{C}$ & $-1.091306 \quad 3.369720-$ & -2.462828 \\
\hline $\mathrm{C}$ & $-0.055860 \quad 1.261482$ & -3.092662 \\
\hline $\mathrm{C}$ & $-0.058085 \quad 2.651270-$ & -3.062768 \\
\hline $\mathrm{H}$ & $-1.031501 \quad 4.448171-$ & -2.408266 \\
\hline $\mathrm{H}$ & $0.769891 \quad 0.7256$ & .541109 \\
\hline $\mathrm{H}$ & $0.776998 \quad 3.192148$ & -3.495663 \\
\hline $\mathrm{C}$ & $-1.421754-2.524821$ & 19255 \\
\hline $\mathrm{C}$ & $-2.386379-3.457238-0$ & 0.427554 \\
\hline $\mathrm{C}$ & $-0.068463-2.890642-0$ & 0.031327 \\
\hline $\mathrm{C}$ & $-1.997068-4.734478-0$ & 0.831525 \\
\hline $\mathrm{H}$ & $-3.435811-3.184870-$ & 443458 \\
\hline $\mathrm{C}$ & $0.318473-4.173770$ & +18941 \\
\hline
\end{tabular}

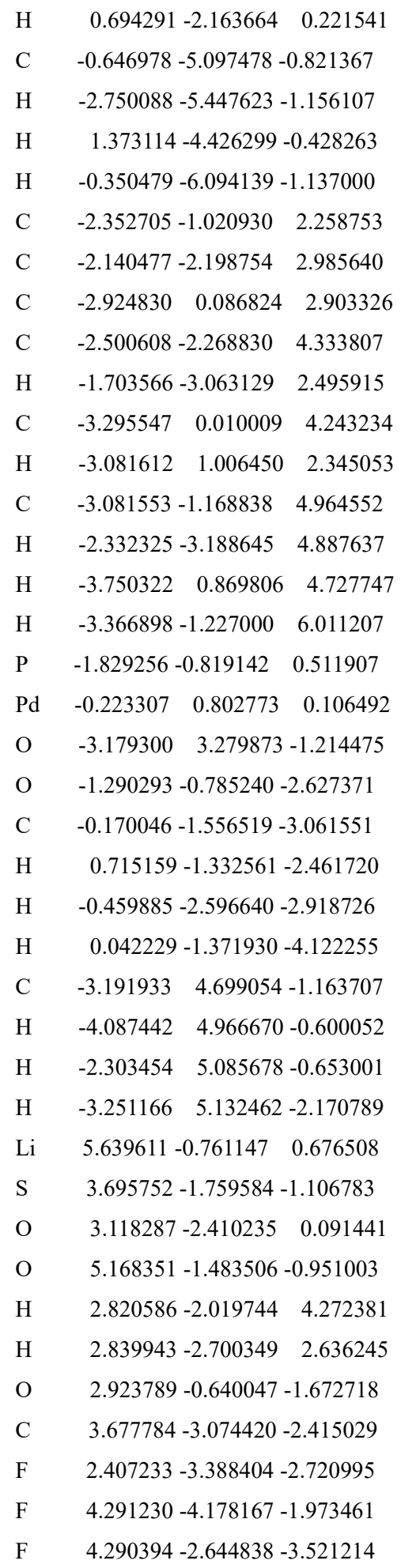

\section{L11-Fb}

$\begin{array}{lcccc}\text { Atom } & \mathrm{X} & \mathrm{Y} & \mathrm{Z} \\ \mathrm{C} & 4.253943 & 1.827524 & 2.276576 \\ \mathrm{C} & 4.194164 & 1.294701 & 0.970273\end{array}$




\begin{tabular}{|c|c|c|c|}
\hline $\mathrm{C}$ & 5.096994 & 1.716788 & -0.008269 \\
\hline $\mathrm{C}$ & 6.057051 & 2.672715 & 0.334529 \\
\hline $\mathrm{C}$ & 6.115488 & 3.199466 & 1.628529 \\
\hline $\mathrm{C}$ & 5.209365 & 2.777488 & 2.609921 \\
\hline $\mathrm{C}$ & 3.092223 & 0.316936 & 0.921344 \\
\hline $\mathrm{H}$ & 5.052267 & 1.317677 & -1.015601 \\
\hline $\mathrm{H}$ & 6.764783 & 3.012387 & -0.416585 \\
\hline $\mathrm{H}$ & 6.867920 & 3.943472 & 1.874537 \\
\hline $\mathrm{H}$ & 5.256004 & 3.190634 & 3.614471 \\
\hline $\mathrm{C}$ & 3.165422 & 1.201161 & 3.110745 \\
\hline $\mathrm{H}$ & 3.560651 & 0.649579 & 3.975611 \\
\hline $\mathrm{H}$ & 2.452000 & 1.932770 & 3.504921 \\
\hline $\mathrm{C}$ & 2.483864 & 0.255078 & 2.141639 \\
\hline $\mathrm{C}$ & 1.320013 & -0.579928 & 2.475833 \\
\hline $\mathrm{C}$ & 0.128361 & -0.002750 & 2.963792 \\
\hline $\mathrm{C}$ & 1.330434 & -1.971339 & 2.205232 \\
\hline $\mathrm{C}$ & -1.021817 & -0.781282 & 3.156192 \\
\hline $\mathrm{C}$ & 0.156380 & -2.734790 & 2.324018 \\
\hline $\mathrm{C}$ & -1.003054 & -2.126874 & 2.811579 \\
\hline $\mathrm{H}$ & -1.936435 & -0.335726 & 3.520620 \\
\hline $\mathrm{H}$ & 0.160363 & -3.793667 & 2.101511 \\
\hline $\mathrm{H}$ & -1.908184 & -2.715370 & 2.916689 \\
\hline $\mathrm{C}$ & 3.826232 & - 1.792484 & 0.936984 \\
\hline $\mathrm{C}$ & 5.074809 & - 1.797784 & 0.302065 \\
\hline $\mathrm{C}$ & 3.538510 & $-2.789000-$ & 883138 \\
\hline $\mathrm{C}$ & 6.017972 & $-2.778601-$ & 0.613888 \\
\hline $\mathrm{H}$ & 5.306331 & -1.046003 & 0.443144 \\
\hline $\mathrm{C}$ & $4.488491-$ & $-3.756348-2$ & 2.207607 \\
\hline $\mathrm{H}$ & 2.554824 & -2.812110 & 2.345200 \\
\hline $\mathrm{C}$ & 5.730880 & $-3.755834-$ & 1.568820 \\
\hline $\mathrm{H}$ & 6.980153 & $-2.776903-$ & 0.109156 \\
\hline $\mathrm{H}$ & 4.254057 & 451025 & 945018 \\
\hline $\mathrm{H}$ & 6.468238 & $-4.516417-$ & -1.809785 \\
\hline $\mathrm{C}$ & 2.546431 & 0.64925 & 850275 \\
\hline $\mathrm{C}$ & 3.109217 & 0.417085 & -3.110792 \\
\hline $\mathrm{C}$ & 1.874179 & 1.856905 & -1.612816 \\
\hline $\mathrm{C}$ & 2.994743 & 1.379299 & -4.117469 \\
\hline $\mathrm{H}$ & 3.640913 & $-0.508726-$ & -3.306727 \\
\hline $\mathrm{C}$ & 1.762780 & 2.815586 & -2.616447 \\
\hline $\mathrm{H}$ & 1.430860 & 2.038638 & -0.640437 \\
\hline $\mathrm{C}$ & 2.320934 & 2.577646 & -3.875152 \\
\hline $\mathrm{H}$ & 3.438171 & 1.19169 & -5.091834 \\
\hline $\mathrm{H}$ & 1.229318 & 3.739876 & -2.415606 \\
\hline $\mathrm{H}$ & 2.231943 & 3.322244 & -4.661077 \\
\hline
\end{tabular}

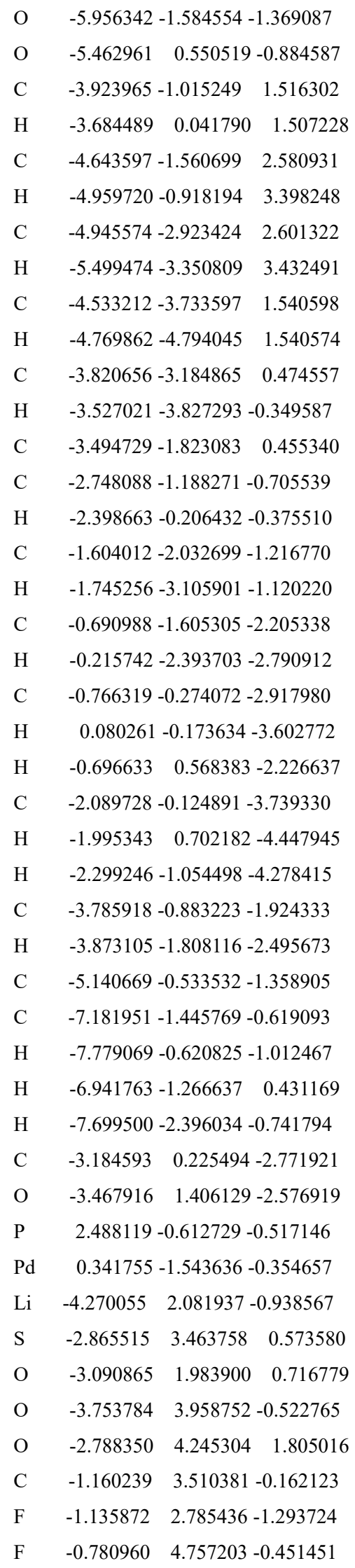




$\begin{array}{cccc}\text { F } & -0.280543 & 2.978120 & 0.701544 \\ \mathrm{O} & 0.167281 & 1.336995 & 3.182524 \\ \mathrm{O} & 2.548545 & -2.510994 & 1.905785 \\ \mathrm{C} & 2.587586 & -3.832930 & 1.385344 \\ \mathrm{H} & 1.946162 & -3.914609 & 0.499258 \\ \mathrm{H} & 3.624960 & -4.006745 & 1.099727 \\ \mathrm{H} & 2.280663 & -4.567990 & 2.139965 \\ \mathrm{C} & -1.040256 & 1.998277 & 3.557266 \\ \mathrm{H} & -0.815408 & 3.063659 & 3.540101 \\ \mathrm{H} & -1.838627 & 1.794521 & 2.840737 \\ \mathrm{H} & -1.352503 & 1.698198 & 4.565649\end{array}$

L11-TS1 (Imaginary frequency:-235.5891 $\mathrm{cm}^{-1}$ )

\begin{tabular}{|c|c|c|}
\hline Atom & $\mathrm{X}$ & $Z$ \\
\hline $\mathrm{C}$ & $-4.588153-1.944842$ & .065477 \\
\hline $\mathrm{H}$ & $-4.818451-3.002126$ & 1.005009 \\
\hline $\mathrm{C}$ & $-3.302126-1.572983$ & 1.391403 \\
\hline $\mathrm{C}$ & $-5.675672-1.032609$ & 0.811494 \\
\hline $\mathrm{O}$ & $-5.643482 \quad 0.189269$ & 0.705019 \\
\hline $\mathrm{O}$ & $-6.855168-1.723091$ & 0.649818 \\
\hline $\mathrm{C}$ & $-7.985719-0.907775$ & 0.351207 \\
\hline $\mathrm{H}$ & $-7.835957-0.350043-0$ & 0.579273 \\
\hline $\mathrm{H}$ & $-8.177337-0.188687$ & 1.153781 \\
\hline $\mathrm{H}$ & $-8.828476-1.594437$ & 0.248956 \\
\hline $\mathrm{O}$ & $-2.823918-0.368924$ & 1.551591 \\
\hline $\mathrm{C}$ & $1.983914 \quad 2.350622$ & -2.948032 \\
\hline $\mathrm{C}$ & $1.923674 \quad 2.332252$ & -1.537485 \\
\hline $\mathrm{C}$ & $2.799227 \quad 3.125545$ & -0.789760 \\
\hline $\mathrm{C}$ & $3.738810 \quad 3.910790$ & -1.463208 \\
\hline $\mathrm{C}$ & $3.809064 \quad 3.909609$ & -2.859191 \\
\hline $\mathrm{C}$ & $2.924152 \quad 3.127346$ & -3.610989 \\
\hline $\mathrm{C}$ & $0.831557 \quad 1.416823$ & -1.135636 \\
\hline $\mathrm{H}$ & $2.757020 \quad 3.136527$ & 0.292720 \\
\hline $\mathrm{H}$ & $4.423452 \quad 4.529436$ & -0.889942 \\
\hline $\mathrm{H}$ & $4.547936 \quad 4.525413$ & -3.363992 \\
\hline $\mathrm{H}$ & $2.967984 \quad 3.137495$ & -4.697219 \\
\hline $\mathrm{C}$ & $0.899918 \quad 1.462348$ & -3.495372 \\
\hline $\mathrm{H}$ & $1.277024 \quad 0.641511$ & -4.116032 \\
\hline $\mathrm{H}$ & $0.179892 \quad 2.016749$ & -4.113162 \\
\hline $\mathrm{C}$ & $0.216827 \quad 0.925841$ & -2.252151 \\
\hline $\mathrm{C}$ & $-0.980547 \quad 0.073899-$ & -2.329517 \\
\hline $\mathrm{C}$ & $-2.196819 \quad 0.485000-$ & -1.733957 \\
\hline $\mathrm{C}$ & $-0.950740-1.163003-3$ & 3.001385 \\
\hline C & $-3.329665-0.339489-1$ & 1.775060 \\
\hline
\end{tabular}

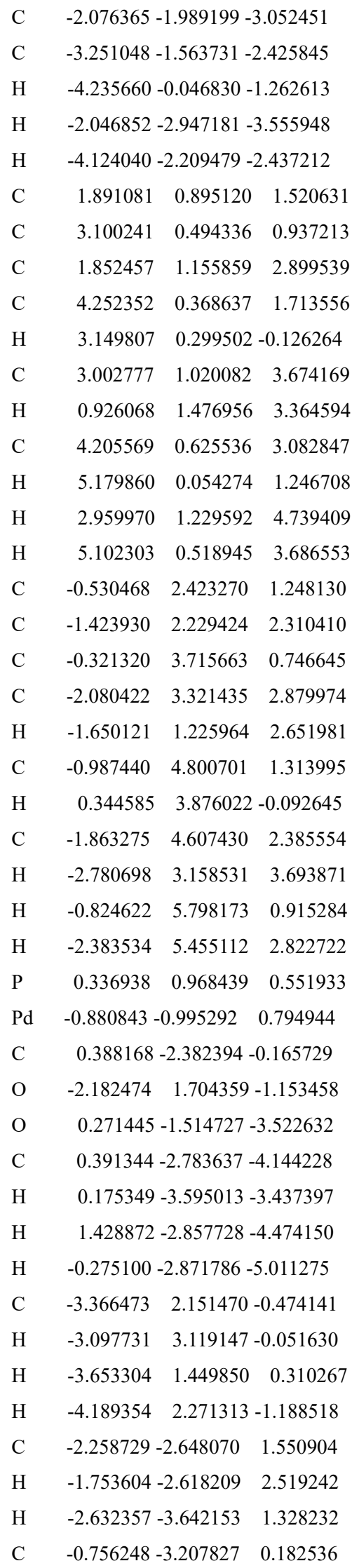




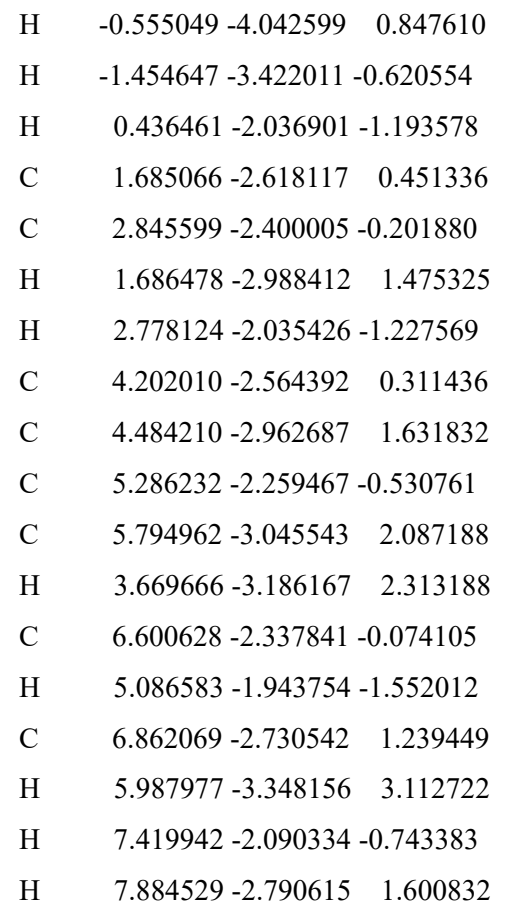

L11-TS2a (Imaginary frequency: $-256.9834 \mathrm{~cm}^{-1}$ )

$\begin{array}{lccc}\text { Atom } & \mathrm{X} & \mathrm{Y} & \mathrm{Z} \\ \mathrm{O} & 4.349907 & 1.067026 & 3.178754 \\ \mathrm{O} & 5.090193 & -0.484993 & 1.723160 \\ \mathrm{C} & 2.830488 & 3.416406 & -0.095663 \\ \mathrm{H} & 3.423851 & 2.746433 & -0.712061 \\ \mathrm{C} & 2.963415 & 4.798228 & -0.216815 \\ \mathrm{H} & 3.674032 & 5.210354 & -0.928221 \\ \mathrm{C} & 2.187633 & 5.650838 & 0.571738 \\ \mathrm{H} & 2.292054 & 6.728394 & 0.481812 \\ \mathrm{C} & 1.276925 & 5.105339 & 1.484142 \\ \mathrm{H} & 0.671936 & 5.761498 & 2.104811 \\ \mathrm{C} & 1.139256 & 3.725343 & 1.603722 \\ \mathrm{H} & 0.410095 & 3.315084 & 2.296147 \\ \mathrm{C} & 1.919248 & 2.855853 & 0.819097 \\ \mathrm{C} & 1.529380 & -0.742156 & 2.058706 \\ \mathrm{H} & 1.933369 & -1.185189 & 1.150514 \\ \mathrm{C} & 0.791436 & -1.702930 & 2.975598 \\ \mathrm{H} & -0.133945 & -2.042910 & 2.502308 \\ \mathrm{H} & 0.496950 & -1.184363 & 3.894124 \\ \mathrm{C} & 1.745118 & -2.896161 & 3.272658 \\ \mathrm{C} & 3.312463 & -1.003395 & 3.240338 \\ \mathrm{H} & 2.832482 & -0.618662 & 4.132127 \\ \mathrm{C} & 4.341616 & -0.172113 & 2.660760 \\ \mathrm{C} & 5.203889 & 2.021530 & 2.522337\end{array}$

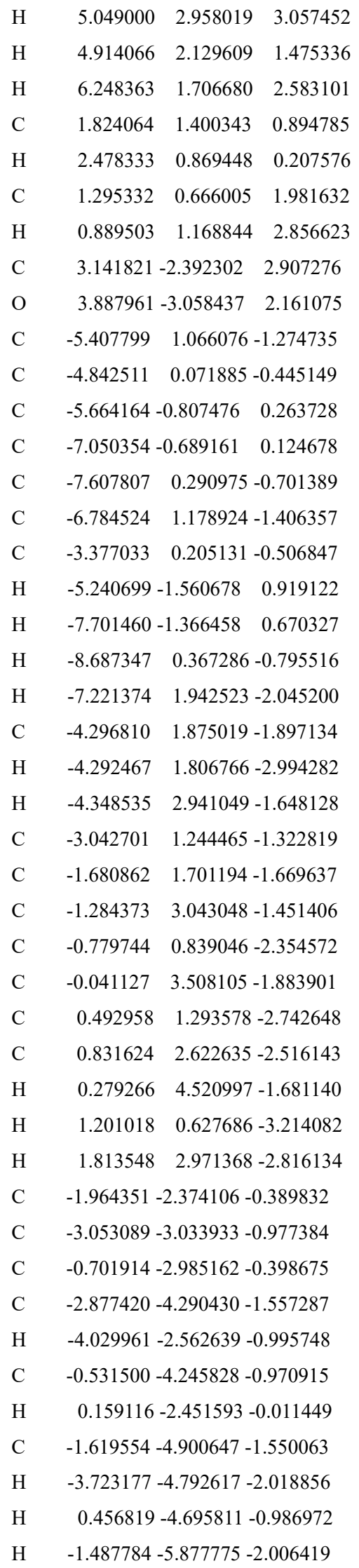




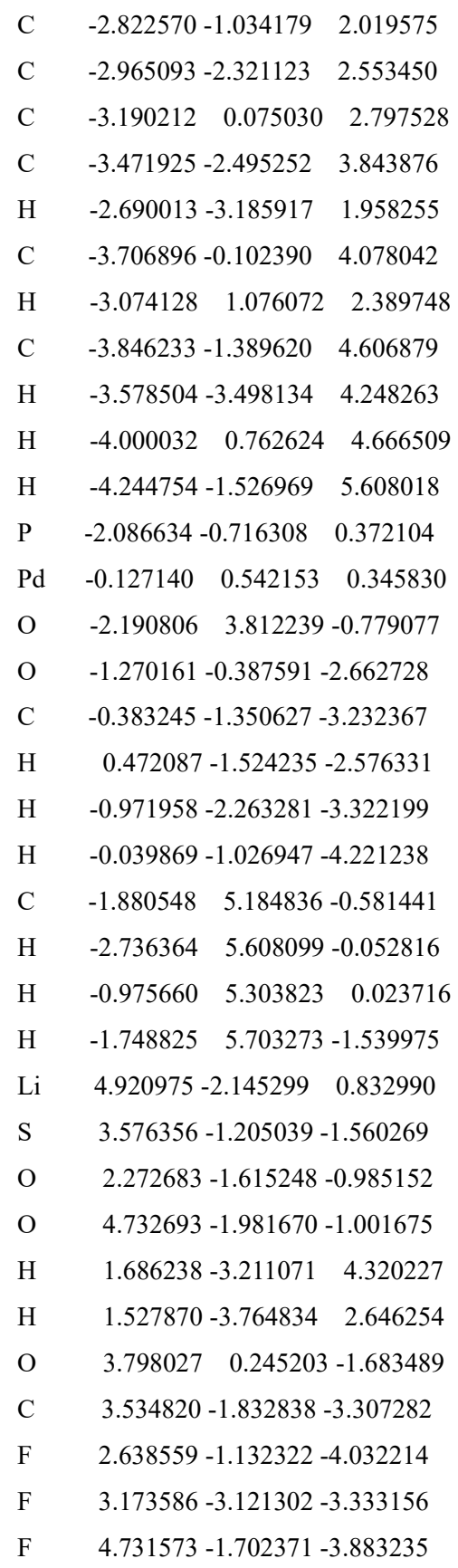

L11-TS2b (Imaginary frequency: $-149.850 \mathrm{~cm}^{-1}$ )
$\begin{array}{llll}\mathrm{H} & -5.072147 & 1.409140 & 0.922542\end{array}$

$\mathrm{H} \quad-6.780856 \quad 3.056196 \quad 0.192567$

$\mathrm{H} \quad-6.851447 \quad 3.841582-2.153208$

$\mathrm{H} \quad-5.211277 \quad 2.989266-3.818582$

C $\quad-3.122306 \quad 1.042211-3.160582$

$\mathrm{H} \quad-3.501888 \quad 0.436506-3.995698$

$\mathrm{H} \quad-2.404171 \quad 1.750967-3.586955$

C $\quad-2.453050 \quad 0.160703-2.123847$

C $\quad-1.288046-0.696284-2.403939$

C $\quad-0.091277-0.141413-2.913141$

C $\quad-1.324673-2.088690-2.137923$

C $\quad 1.035514-0.944695-3.133226$

C $\quad-0.172061-2.879754-2.298097$

C $\quad 0.989462-2.295232-2.805124$

$\mathrm{H} \quad 1.953457-0.516994-3.510220$

H $\quad-0.196697-3.939258-2.078740$

$\mathrm{H} \quad 1.879364-2.902481-2.934187$

C $\quad-3.821882-1.741097 \quad 1.017672$

C $\quad-5.062472-1.784208 \quad 0.368905$

C $\quad-3.531155-2.697822 \quad 2.002699$

C $\quad-5.995697-2.766645 \quad 0.704415$

H $\quad-5.295104-1.061072-0.403926$

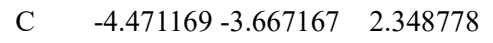

$\mathrm{H} \quad-2.556000-2.687608 \quad 2.482580$

C $\quad-5.705427-3.706425 \quad 1.695335$

$\mathrm{H} \quad-6.952219-2.795536 \quad 0.190123$

$\mathrm{H} \quad-4.235896-4.399711 \quad 3.115888$

$\mathrm{H} \quad-6.434866-4.468582 \quad 1.954310$

$\begin{array}{llll}\text { C } & -2.577628 & 0.751812 & 1.854281\end{array}$

$\begin{array}{lllll}\text { C } & -3.246214 & 0.599002 & 3.074457\end{array}$

$\begin{array}{lllll}\text { C } & -1.828531 & 1.914054 & 1.618758\end{array}$

$\begin{array}{lllll}\text { C } & -3.165077 & 1.600367 & 4.045262\end{array}$

$\mathrm{H} \quad-3.832460-0.294153 \quad 3.265862$

$\begin{array}{llll}\text { C } & -1.752535 & 2.911497 & 2.587090\end{array}$

$\begin{array}{llll}\mathrm{H} & -1.298346 & 2.031263 & 0.679967\end{array}$

$\begin{array}{llll}\text { C } & -2.419682 & 2.755680 & 3.805004\end{array}$

$\mathrm{H} \quad-3.688580 \quad 1.476389 \quad 4.989382$

$\begin{array}{llll}\mathrm{H} & -1.157749 & 3.798594 & 2.394193\end{array}$

$\mathrm{H} \quad-2.355880 \quad 3.530425 \quad 4.563632$

O $\quad 5.970135-1.626919 \quad 1.383765$

$\begin{array}{llll}\text { O } & 5.496772 & 0.533647 & 0.955740\end{array}$

C $\quad 3.914278-1.048967-1.432845$

$\mathrm{H} \quad 3.686274 \quad 0.010100-1.418945$

C $\quad 4.685233-1.590722-2.460576$ 


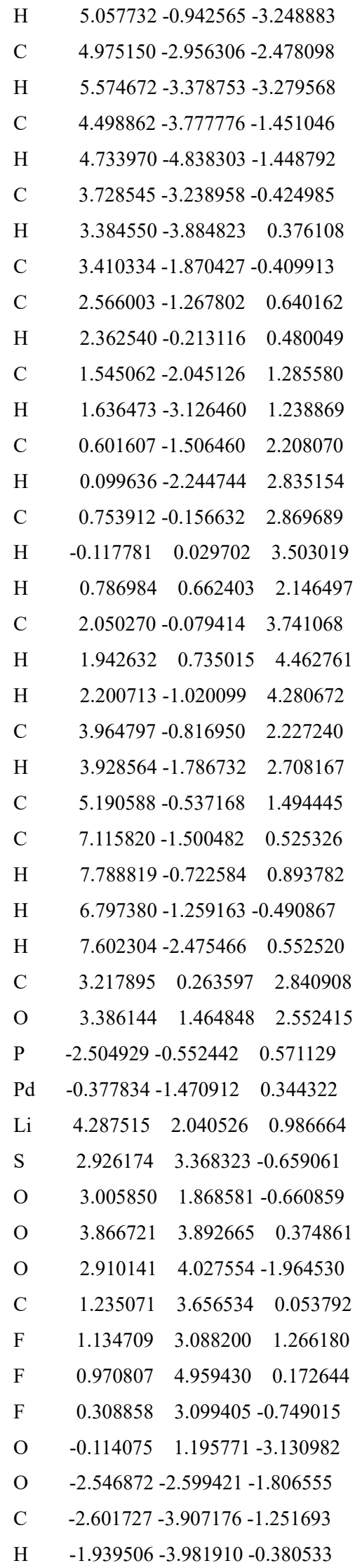

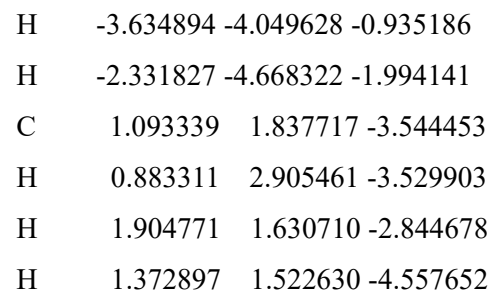

\section{L12-A}

\begin{tabular}{|c|c|c|c|}
\hline tom & $X$ & Y & $\mathrm{Z}$ \\
\hline $\mathrm{C}$ & -2.798512 & $47842-0$. & .952805 \\
\hline $\mathrm{H}$ & $-1.978855-$ & $-3.611379-1$. & 199335 \\
\hline $\mathrm{C}$ & $-2.720157-$ & $1.656761-1$. & .387754 \\
\hline $\mathrm{C}$ & -3.834543 & $-3.503408-0$ & .088741 \\
\hline $\mathrm{O}$ & $-4.870200-$ & -2.993085 & 0.286916 \\
\hline $\mathrm{O}$ & -3.448380 & $-4.761112 \quad 0$ & 0.323533 \\
\hline $\mathrm{C}$ & -4.385448 & -5.409515 & 1.186547 \\
\hline $\mathrm{H}$ & $-3.958547-$ & -6.390197 & 1.404039 \\
\hline $\mathrm{H}$ & -4.525958 & -4.839524 & 2.110153 \\
\hline $\mathrm{H}$ & $-5.357415-$ & -5.516126 & 0.696194 \\
\hline $\mathrm{O}$ & $-3.768387-$ & $-0.830844-1$. & 1.213838 \\
\hline $\mathrm{C}$ & $-1.492218-$ & $1.166243-2$. & 2.041813 \\
\hline $\mathrm{H}$ & $-1.663198-$ & $-0.531188-2$. & 2.913441 \\
\hline $\mathrm{H}$ & $-0.784366-$ & $-1.963175-2$. & .261826 \\
\hline $\mathrm{C}$ & -3.691226 & $0.599920-1$ & 1.287780 \\
\hline $\mathrm{O}$ & -4.758419 & $1.151091-1$ & -1.445823 \\
\hline $\mathrm{O}$ & -2.537408 & $1.142835-1$ & -1.147003 \\
\hline $\mathrm{C}$ & 4.234695 & 1.497311 & 1.088218 \\
\hline $\mathrm{C}$ & 3.801304 & 0.268971 & 0.541348 \\
\hline $\mathrm{C}$ & $4.716967-$ & -0.744018 & 0.251627 \\
\hline $\mathrm{C}$ & $6.069099-$ & -0.518257 & 0.525878 \\
\hline $\mathrm{C}$ & 6.497128 & 0.694346 & 1.074779 \\
\hline $\mathrm{C}$ & 5.578572 & 1.713077 & 1.359425 \\
\hline $\mathrm{C}$ & 2.341145 & 0.347168 & 0.360288 \\
\hline $\mathrm{H}$ & 4.391323 & $-1.682727-0$ & 0.184318 \\
\hline $\mathrm{H}$ & 6.796012 & -1.294550 & 0.305311 \\
\hline $\mathrm{H}$ & 7.552361 & 0.850032 & 1.279077 \\
\hline $\mathrm{H}$ & 5.917326 & 2.655315 & 1.782231 \\
\hline $\mathrm{C}$ & 3.038319 & 2.399377 & 1.275754 \\
\hline $\mathrm{H}$ & 2.862305 & 2.651725 & 2.331440 \\
\hline $\mathrm{H}$ & 3.130201 & 3.356670 & 0.746463 \\
\hline $\mathrm{C}$ & 1.884698 & 1.569238 & 0.740910 \\
\hline $\mathrm{C}$ & 0.498494 & 2.102497 & 0.653754 \\
\hline $\mathrm{C}$ & 0.208264 & (1.076079 & -0.347212 \\
\hline $\mathrm{C}$ & -0.473301 & 1.810483 & 1.653100 \\
\hline
\end{tabular}



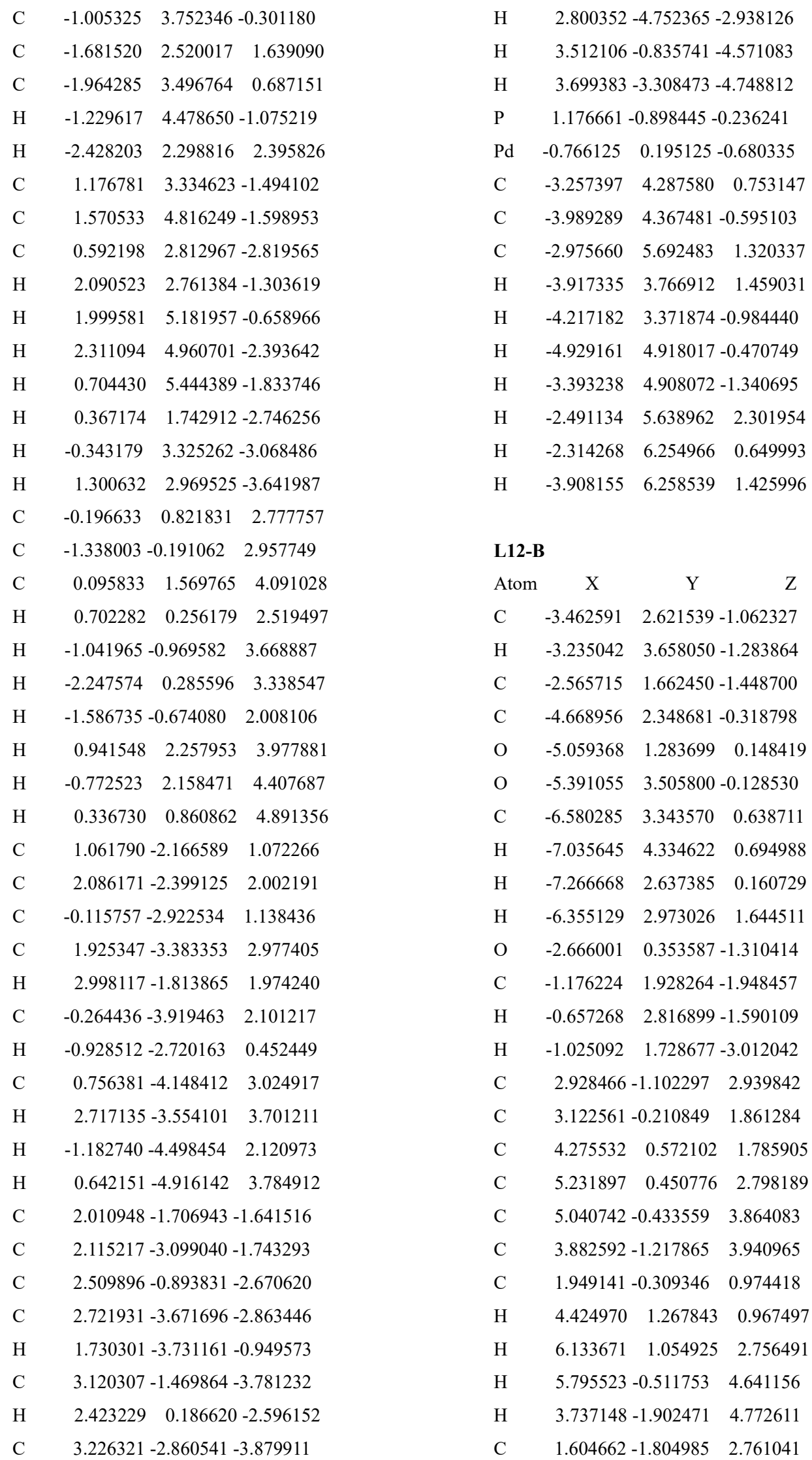

L12-B

$\begin{array}{lccc}\text { Atom } & \mathrm{X} & \mathrm{Y} & \mathrm{Z} \\ \mathrm{C} & -3.462591 & 2.621539 & -1.062327 \\ \mathrm{H} & -3.235042 & 3.658050 & -1.283864 \\ \mathrm{C} & -2.565715 & 1.662450 & -1.448700 \\ \mathrm{C} & -4.668956 & 2.348681 & -0.318798 \\ \mathrm{O} & -5.059368 & 1.283699 & 0.148419 \\ \mathrm{O} & -5.391055 & 3.505800 & -0.128530 \\ \mathrm{C} & -6.580285 & 3.343570 & 0.638711 \\ \mathrm{H} & -7.035645 & 4.334622 & 0.694988 \\ \mathrm{H} & -7.266668 & 2.637385 & 0.160729 \\ \mathrm{H} & -6.355129 & 2.973026 & 1.644511 \\ \mathrm{O} & -2.666001 & 0.353587 & -1.310414 \\ \mathrm{C} & -1.176224 & 1.928264 & -1.948457 \\ \mathrm{H} & -0.657268 & 2.816899 & -1.590109 \\ \mathrm{H} & -1.025092 & 1.728677 & -3.012042 \\ \mathrm{C} & 2.928466 & -1.102297 & 2.939842 \\ \mathrm{C} & 3.122561 & -0.210849 & 1.861284 \\ \mathrm{C} & 4.275532 & 0.572102 & 1.785905 \\ \mathrm{C} & 5.231897 & 0.450776 & 2.798189 \\ \mathrm{C} & 5.040742 & -0.433559 & 3.864083 \\ \mathrm{C} & 3.882592 & -1.217865 & 3.940965 \\ \mathrm{C} & 1.949141 & -0.309346 & 0.974418 \\ \mathrm{H} & 4.424970 & 1.267843 & 0.967497 \\ \mathrm{H} & 6.133671 & 1.054925 & 2.756491 \\ \mathrm{H} & 5.795523 & -0.511753 & 4.641156 \\ \mathrm{H} & 3.737148 & -1.902471 & 4.772611 \\ \mathrm{C} & 1.604662 & -1.804985 & 2.761041\end{array}$




\begin{tabular}{|c|c|c|}
\hline$\Pi$ & $1.716270-2.892884$ & 2.646242 \\
\hline 11 & $0.919193-1.658055$ & 3.605883 \\
\hline$c$ & $.053348-1.199893$ & 1.482862 \\
\hline$C$ & $-0.269480-1.585767$ & 0.924128 \\
\hline $\mathrm{C}$ & $-1.459568-1.130230$ & 1.556497 \\
\hline $\mathrm{C}$ & \multicolumn{2}{|c|}{$-0.359667-2.484201-0.180595$} \\
\hline C & $-2.693420-1.589593$ & 1.097513 \\
\hline $\mathrm{C}$ & \multicolumn{2}{|c|}{$-1.629445-2.899961-0.600663$} \\
\hline $\mathrm{C}$ & $-2.803601-2.469609$ & 0.018377 \\
\hline $\mathrm{H}$ & $-3.595075-1.188241$ & 1.542969 \\
\hline It & \multicolumn{2}{|c|}{$-1.704346-3.572495-1.450807$} \\
\hline$c$ & $-1.424515-0.077288$ & 2.655562 \\
\hline 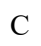 & $-2.046428-0.601020$ & 3.960433 \\
\hline $\mathrm{C}$ & $-2.113176 \quad 1.219447$ & 2.189552 \\
\hline $\mathrm{H}$ & $-0.376194 \quad 0.168793$ & 2.859783 \\
\hline $\mathrm{H}$ & $-1.546399-1.514259$ & 4.304392 \\
\hline $\mathrm{H}$ & $-1.968953 \quad 0.152679$ & 4.752299 \\
\hline $\mathrm{H}$ & $-3.107987-0.834657$ & 3.824739 \\
\hline $\mathrm{H}$ & $-1.615686 \quad 1.627538$ & 1.304211 \\
\hline $\mathrm{H}$ & $-3.155994 \quad 1.050771$ & 1.905304 \\
\hline $\mathrm{H}$ & $-2.083955 \quad 1.972230$ & 2.986880 \\
\hline $\mathrm{C}$ & \multicolumn{2}{|c|}{$0.879118-3.074034-0.843407$} \\
\hline $\mathrm{C}$ & \multicolumn{2}{|c|}{$0.844956-2.957265-2.374690$} \\
\hline $\mathrm{C}$ & \multicolumn{2}{|c|}{$1.075541-4.535249-0.400805$} \\
\hline $\mathrm{H}$ & \multicolumn{2}{|c|}{$1.748923-2.511074-0.496995$} \\
\hline $\mathrm{H}$ & \multicolumn{2}{|c|}{$0.646126-1.926046-2.681751$} \\
\hline $\mathrm{H}$ & \multicolumn{2}{|c|}{$1.809080-3.260322-2.797564$} \\
\hline $\mathrm{H}$ & \multicolumn{2}{|c|}{$0.069237-3.594980-2.812665$} \\
\hline $\mathrm{H}$ & \multicolumn{2}{|c|}{$1.150890-4.612804 \quad 0.689937$} \\
\hline $\mathrm{H}$ & \multicolumn{2}{|c|}{$0.231997-5.157535-0.720666$} \\
\hline $\mathrm{H}$ & \multicolumn{2}{|c|}{$1.990786-4.951290-0.837811$} \\
\hline $\mathrm{C}$ & \multicolumn{2}{|c|}{$2.788806-0.046884-1.808632$} \\
\hline $\mathrm{C}$ & \multicolumn{2}{|c|}{$3.881513-0.857231-1.475251$} \\
\hline $\mathrm{C}$ & \multicolumn{2}{|c|}{$2.544641 \quad 0.264028-3.155567$} \\
\hline $\mathrm{C}$ & \multicolumn{2}{|c|}{$4.717634-1.349928-2.478716$} \\
\hline $\mathrm{H}$ & \multicolumn{2}{|c|}{$4.078451-1.107912-0.439063$} \\
\hline $\mathrm{C}$ & \multicolumn{2}{|c|}{$3.390529-0.216882-4.152309$} \\
\hline $\mathrm{H}$ & \multicolumn{2}{|c|}{$1.679872 \quad 0.867526-3.417475$} \\
\hline $\mathrm{C}$ & \multicolumn{2}{|c|}{$4.476112-1.029629-3.815201$} \\
\hline $\mathrm{H}$ & \multicolumn{2}{|c|}{$5.558596-1.984025-2.213175$} \\
\hline $\mathrm{H}$ & \multicolumn{2}{|c|}{$3.193916 \quad 0.028179-5.191903$} \\
\hline $\mathrm{H}$ & \multicolumn{2}{|c|}{$5.127916-1.415866-4.593443$} \\
\hline $\mathrm{C}$ & $2.071519 \quad 2.302576$ & -0.253207 \\
\hline $\mathrm{C}$ & $3.158103 \quad 2.9203$ & .8833 \\
\hline
\end{tabular}

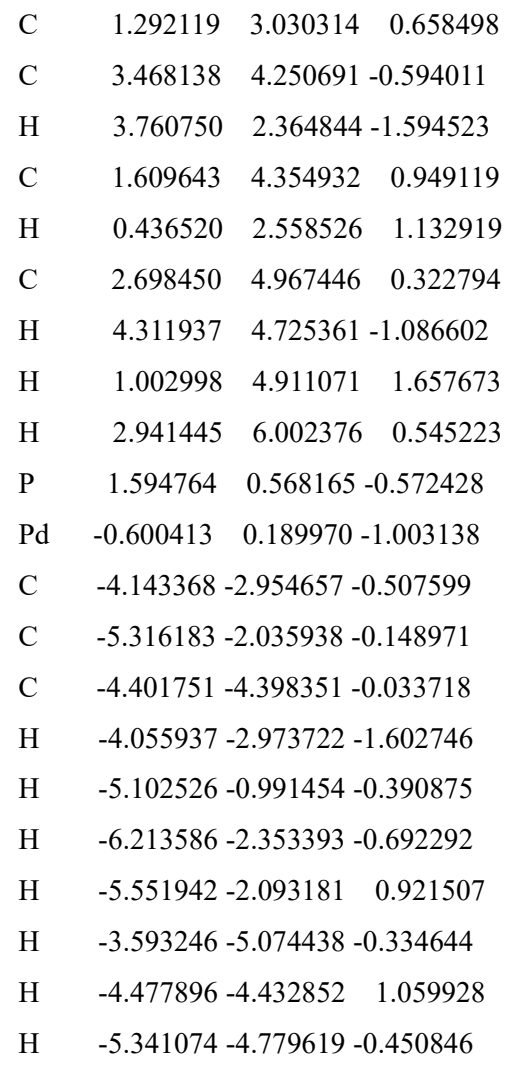

\section{L12-B0}

$\begin{array}{lcrr}\text { Atom } & \mathrm{X} & \mathrm{Y} & \mathrm{Z} \\ \mathrm{C} & -2.912318 & -3.508353 & 0.988066 \\ \mathrm{H} & -3.043264 & -4.432079 & 0.435556 \\ \mathrm{C} & -1.708752 & -2.871579 & 0.853287 \\ \mathrm{C} & -4.057851 & -3.026190 & 1.721605 \\ \mathrm{O} & -4.154572 & -2.040491 & 2.439945 \\ \mathrm{O} & -5.144811 & -3.842821 & 1.491040 \\ \mathrm{C} & -6.339171 & -3.441012 & 2.157572 \\ \mathrm{H} & -7.092917 & -4.184501 & 1.890633 \\ \mathrm{H} & -6.657215 & -2.445538 & 1.830434 \\ \mathrm{H} & -6.197171 & -3.415667 & 3.242485 \\ \mathrm{O} & -1.305975 & -1.719288 & 1.360908 \\ \mathrm{C} & 0.086169 & 4.900920 & -0.251585 \\ \mathrm{C} & 0.941393 & 3.875245 & 0.208299 \\ \mathrm{C} & 2.178305 & 4.197474 & 0.773253 \\ \mathrm{C} & 2.552498 & 5.541764 & 0.851922 \\ \mathrm{C} & 1.710876 & 6.552591 & 0.379116 \\ \mathrm{C} & 0.464536 & 6.234228 & -0.173132 \\ \mathrm{C} & 0.257135 & 2.577178 & -0.010803 \\ \mathrm{H} & 2.838713 & 3.426232 & 1.150562 \\ \mathrm{H} & 3.512829 & 5.801597 & 1.288259\end{array}$




\begin{tabular}{|c|c|c|}
\hline $\mathrm{H}$ & 2.021524 & $7.591161 \quad 0.44769$ \\
\hline $\mathrm{H}$ & -0.197301 & $020380-0.527680$ \\
\hline C & -1.192314 & $4.283966-0.756316$ \\
\hline $\mathrm{H}$ & -1.425492 & $4.546300-1.795970$ \\
\hline $\mathrm{H}$ & -2.063855 & $4.594955-0.162905$ \\
\hline $\mathrm{C}$ & -0.961387 & $2.796184-0.577493$ \\
\hline $\mathrm{C}$ & -1.952105 & $1.748487-0.909902$ \\
\hline 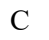 & -2.715330 & $1.162864 \quad 0.123792$ \\
\hline $\mathrm{C}$ & -2.079359 & $1.304397-2.243809$ \\
\hline $\mathrm{C}$ & -3.515543 & $0.057606-0.182833$ \\
\hline $\mathrm{C}$ & -2.912083 & $0.215326-2.505556$ \\
\hline $\mathrm{C}$ & $-3.606892-c$ & $0.443126-1.482909$ \\
\hline $\mathrm{H}$ & $-4.054371-($ & $-0.439233 \quad 0.616589$ \\
\hline $\mathrm{H}$ & $-3.020784-($ & $0.132651-3.529665$ \\
\hline $\mathrm{C}$ & 2.650163 & $1.071631 \quad 0.096934$ \\
\hline $\mathrm{C}$ & 3.053418 & $1.653138-1.115347$ \\
\hline 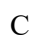 & 3.625841 & $0.583911 \quad 0.975039$ \\
\hline $\mathrm{C}$ & 4.406635 & $1.764722-1.431796$ \\
\hline $\mathrm{H}$ & 2.306783 & $2.050929-1.797619$ \\
\hline$\Gamma$ & 4.980075 & $0.696010 \quad 0.656964$ \\
\hline $\mathrm{H}$ & 3.328926 & $0.133890 \quad 1.916400$ \\
\hline $\mathrm{C}$ & 5.374833 & $1.290573-0.542905$ \\
\hline $\mathrm{H}$ & 4.704669 & $2.232029-2.365965$ \\
\hline $\mathrm{H}$ & 5.726272 & $0.313936 \quad 1.347175$ \\
\hline $\mathrm{H}$ & 6.429708 & $1.385341-0.784321$ \\
\hline $\mathrm{C}$ & 0.774159 & $0.907164 \quad 2.290903$ \\
\hline $\mathrm{C}$ & 0.89501 & $-0.325374 \quad 2.950248$ \\
\hline $\mathrm{C}$ & 0.565326 & $2.069127 \quad 3.047194$ \\
\hline $\mathrm{C}$ & 0.82566 & $-0.391458 \quad 4.340964$ \\
\hline $\mathrm{H}$ & $1.001516-$ & $-1.237708 \quad 2.374101$ \\
\hline $\mathrm{C}$ & 0.482835 & $1.996631 \quad 4.436931$ \\
\hline $\mathrm{H}$ & 0.458953 & $3.028922 \quad 2.557264$ \\
\hline $\mathrm{C}$ & 0.615720 & $0.768588 \quad 5.086854$ \\
\hline $\mathrm{H}$ & 0.90929 & $-1.353855 \quad 4.836848$ \\
\hline $\mathrm{H}$ & 0.310870 & $2.902571 \quad 5.011150$ \\
\hline $\mathrm{H}$ & 0.543681 & $0.714510 \quad 6.169338$ \\
\hline $\mathrm{P}$ & 0.851990 & $0.917344 \quad 0.458199$ \\
\hline $\mathrm{Pd}$ & \multicolumn{2}{|c|}{$-0.041656-1.331287-0.282006$} \\
\hline $\mathrm{C}$ & \multicolumn{2}{|c|}{$5.620613-4.991046 \quad 0.111569$} \\
\hline $\mathrm{C}$ & \multicolumn{2}{|c|}{$4.576717-4.197059-0.351100$} \\
\hline $\mathrm{C}$ & \multicolumn{2}{|c|}{$4.817399-2.891304-0.819972$} \\
\hline $\mathrm{C}$ & \multicolumn{2}{|c|}{$6.139435-2.410874-0.794563$} \\
\hline $\mathrm{C}$ & \multicolumn{2}{|c|}{$7.185020-3.206573-0.332424$} \\
\hline $\mathrm{C}$ & \multicolumn{2}{|c|}{$6.930482-4.501368 \quad 0.122034$} \\
\hline
\end{tabular}

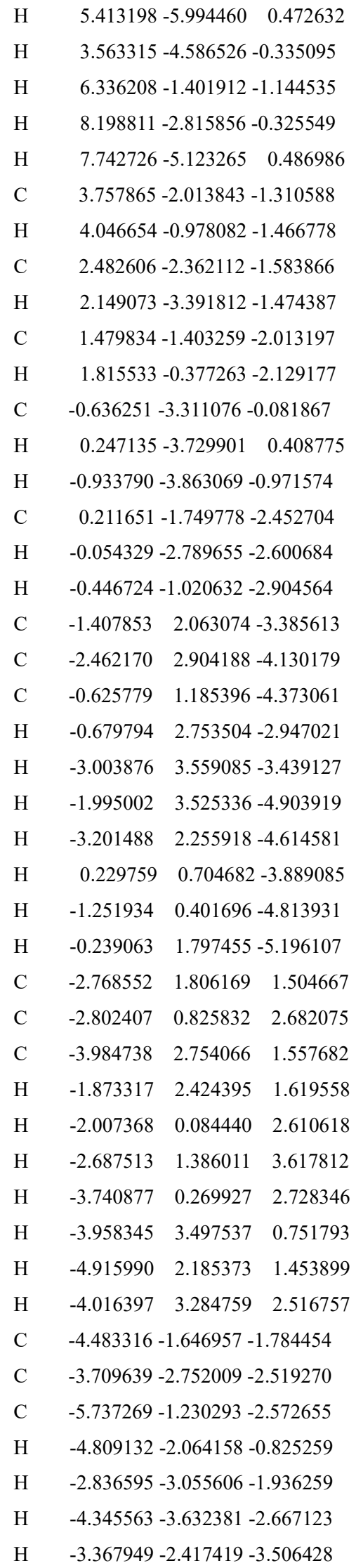




$$
\begin{array}{ll}
\mathrm{H} & -6.307880-0.469782-2.028685 \\
\mathrm{H} & -5.466871-0.810134-3.549270 \\
\mathrm{H} & -6.391627-2.092718-2.746668
\end{array}
$$

\begin{tabular}{|c|c|c|c|}
\hline Atom & $\mathrm{X}$ & $Y$ & Z \\
\hline $\mathrm{C}$ & \multicolumn{3}{|c|}{$-4.053713-3.002898-0.718035$} \\
\hline $\mathrm{H}$ & \multicolumn{3}{|c|}{$-4.492918-3.570709-1.528786$} \\
\hline $\mathrm{C}$ & \multicolumn{3}{|c|}{$-2.832405-2.399009-0.912568$} \\
\hline $\mathrm{C}$ & \multicolumn{3}{|c|}{$\begin{array}{lll}-4.820919-2.905863 & 0.500619\end{array}$} \\
\hline $\mathrm{O}$ & \multicolumn{3}{|c|}{$-4.544410-2.328890 \quad 1.546441$} \\
\hline $\mathrm{O}$ & \multicolumn{3}{|c|}{$-6.023169-3.568604 \quad 0.358650$} \\
\hline $\mathrm{C}$ & \multicolumn{3}{|c|}{$\begin{array}{lll}-6.867663 & -3.519901 & 1.503783\end{array}$} \\
\hline $\mathrm{H}$ & \multicolumn{3}{|c|}{$-7.742005-4.125252 \quad 1.255068$} \\
\hline $\mathrm{H}$ & \multicolumn{3}{|c|}{$\begin{array}{lll}-7.175260 & -2.492093 & 1.727112\end{array}$} \\
\hline $\mathrm{H}$ & \multicolumn{3}{|c|}{$-6.363545-3.924364 \quad 2.387073$} \\
\hline $\mathrm{O}$ & \multicolumn{3}{|c|}{$-2.215558-1.706298-0.014917$} \\
\hline $\mathrm{C}$ & 1.066713 & 4.661507 & 0.291368 \\
\hline $\mathrm{C}$ & 1.871716 & 3.504226 & 0.208613 \\
\hline $\mathrm{C}$ & 3.263302 & 3.609103 & 0.214785 \\
\hline $\mathrm{C}$ & 3.837593 & 4.880628 & 0.297464 \\
\hline $\mathrm{C}$ & 3.039780 & 6.026125 & 0.37532 \\
\hline $\mathrm{C}$ & 1.643300 & 5.921458 & 0.374327 \\
\hline $\mathrm{C}$ & 0.976444 & 2.330775 & 0.136876 \\
\hline $\mathrm{H}$ & 3.890161 & 2.727406 & 0.152108 \\
\hline $\mathrm{H}$ & 4.919506 & 4.978286 & 0.30090 \\
\hline $\mathrm{H}$ & 3.506271 & 7.005008 & 0.4 \\
\hline $\mathrm{H}$ & 1.025022 & 6.813193 & 0.43871 \\
\hline $\mathrm{C}$ & -0.382834 & 4.247194 & 0.279665 \\
\hline $\mathrm{H}$ & -0.953109 & $4.686413-0$ & -0.549699 \\
\hline $\mathrm{H}$ & -0.915235 & 4.532976 & 1.198228 \\
\hline $\mathrm{C}$ & -0.320380 & 2.734234 & 0.163593 \\
\hline $\mathrm{C}$ & -1.566266 & 1.931896 & 0.078623 \\
\hline $\mathrm{C}$ & -2.157844 & 1.367312 & 1.237880 \\
\hline $\mathrm{C}$ & -2.264903 & $1.902093-1$ & -1.155532 \\
\hline $\mathrm{C}$ & -3.444091 & 0.828716 & 1.138371 \\
\hline $\mathrm{C}$ & -3.551637 & $1.368713-1$ & 1.192386 \\
\hline $\mathrm{C}$ & -4.172768 & $0.853904-0$ & -0.050398 \\
\hline $\mathrm{H}$ & -3.892630 & 0.358100 & 2.006738 \\
\hline $\mathrm{H}$ & -4.084508 & $1.354310-2$ & -2.137613 \\
\hline $\mathrm{C}$ & 2.785843 & 0.525157 & -1.152490 \\
\hline $\mathrm{C}$ & 2.450205 & 0.773648 & -2.491747 \\
\hline $\mathrm{C}$ & 4.110681 & $0.225410-0$ & -0.818181 \\
\hline $\mathrm{C}$ & 3.429330 & 0.725756 & -3.481739 \\
\hline
\end{tabular}

\section{L12-C}

$\begin{array}{ll}1.421515 & 1.001060-2.755987\end{array}$

C $\quad 5.089963 \quad 0.182254-1.811504$

H $\quad 4.377098 \quad 0.014085 \quad 0.211318$

C $\quad 4.752551 \quad 0.428554-3.142867$

$\mathrm{H} \quad 3.161103 \quad 0.918873-4.516383$

H $\quad 6.114409-0.056450-1.541765$

$\mathrm{H} \quad 5.515618 \quad 0.389225-3.914837$

$\begin{array}{llll}\text { C } & 2.210480 & 0.263558 & 1.698280\end{array}$

C $\quad 2.695626-1.023627 \quad 1.976300$

$\begin{array}{llll}\text { C } & 2.270824 & 1.245470 & 2.696556\end{array}$

C $\quad 3.246489-1.318722 \quad 3.220546$

$\mathrm{H} \quad 2.647910-1.788961 \quad 1.214877$

$\begin{array}{llll}\text { C } & 2.806329 & 0.941005 & 3.948938\end{array}$

$\begin{array}{llll}\mathrm{H} & 1.903886 & 2.245968 & 2.502307\end{array}$

C $\quad 3.297448-0.337815 \quad 4.213601$

$\mathrm{H} \quad 3.634222-2.315825 \quad 3.407366$

$\begin{array}{llll}\mathrm{H} & 2.842633 & 1.709309 & 4.715924\end{array}$

$\mathrm{H} \quad 3.717695-0.569070 \quad 5.188168$

P $\quad 1.429233 \quad 0.578405 \quad 0.070846$

$\mathrm{Pd} \quad-0.468937-0.691903-0.225425$

C $\quad 4.912209-4.663912 \quad 1.277852$

C $\quad 3.792125-4.113909 \quad 0.662294$

C $\quad 3.909996-3.378231-0.534157$

C $\quad 5.194617-3.229668-1.088215$

C $\quad 6.316015-3.781568-0.473226$

C $\quad 6.182023-4.499039 \quad 0.716407$

$\mathrm{H} \quad 4.794502-5.227527 \quad 2.199457$

$\mathrm{H} \quad 2.816066-4.256123 \quad 1.116218$

$\mathrm{H} \quad 5.303083-2.666322-2.010374$

H $\quad 7.296549-3.650952-0.923105$

$\mathrm{H} \quad 7.054591-4.927992 \quad 1.200344$

C $\quad 2.773377-2.741399-1.200704$

H $\quad 3.023139-2.146222-2.076249$

C $\quad 1.478122-2.803925-0.823230$

$\mathrm{H} \quad 1.187676-3.424905 \quad 0.023424$

C $\quad 0.368407-2.130899-1.511237$

H $\quad 0.722108-1.501932-2.334709$

C $\quad-2.112584-2.569846-2.236093$

$\mathrm{H} \quad-2.667893-3.250565-2.888632$

H $\quad-2.054655-1.596465-2.742046$

C $\quad-0.699564-3.117238-1.983685$

H $\quad-0.774558-3.948587-1.272162$

H $\quad-0.315776-3.547163-2.921327$

C $\quad-1.627289 \quad 2.420639-2.437531$ 


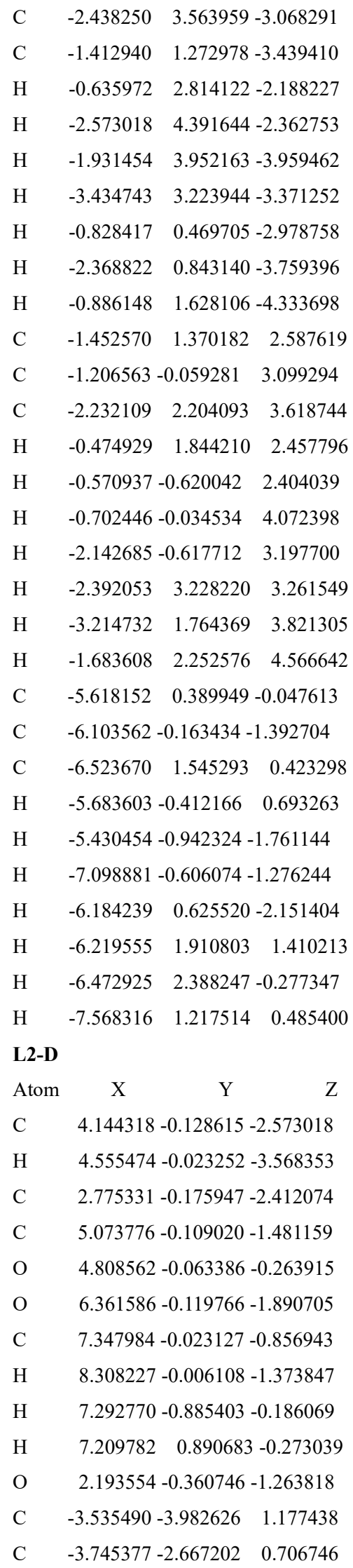

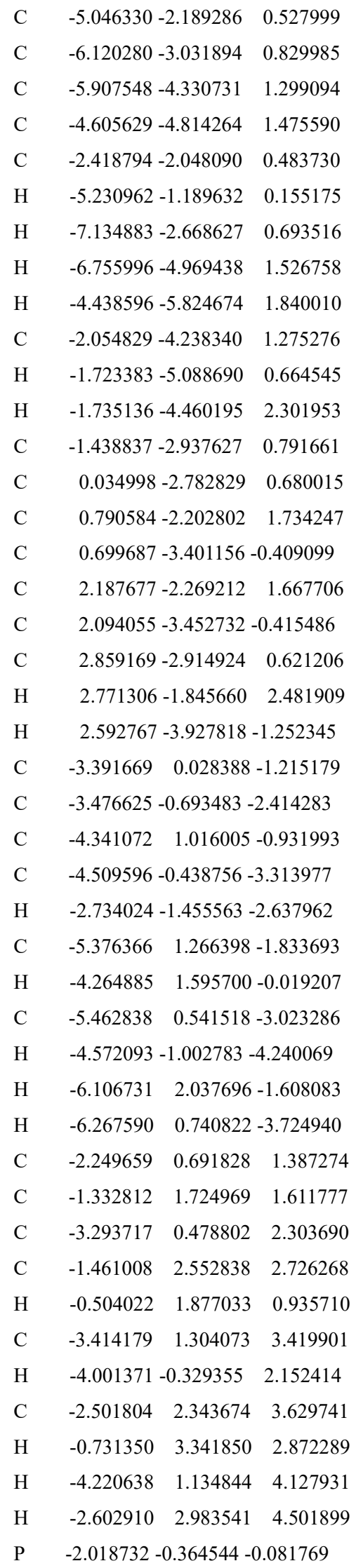




\begin{tabular}{|c|c|c|c|}
\hline d & 0.13579 & 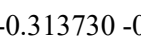 & 43 \\
\hline $\mathrm{C}$ & -2.363579 & 5.806538 & 0.477150 \\
\hline$C$ & -1.783298 & 4.716343 & -0.163377 \\
\hline $\mathrm{C}$ & -2.483682 & 4.030476 & 1.175849 \\
\hline $\mathrm{C}$ & -3.773172 & 4.478894 & -1.518138 \\
\hline C & -4.350134 & 5.570765 & -0.874499 \\
\hline $\mathrm{C}$ & -3.646959 & 6.239107 & 0.129600 \\
\hline $\mathrm{H}$ & -1.808808 & 6.320676 & 1.257097 \\
\hline $\mathrm{H}$ & -0.789207 & 4.397445 & 0.129498 \\
\hline $\mathrm{H}$ & -4.320377 & 3.956632 & -2.298535 \\
\hline $\mathrm{H}$ & -5.346690 & 5.900698 & -1.156015 \\
\hline $\mathrm{H}$ & -4.093915 & 7.089623 & 0.636855 \\
\hline $\mathrm{C}$ & -1.943768 & 2.854891 & 1.854123 \\
\hline $\mathrm{H}$ & -2.632106 & 2.349863 & -2.527513 \\
\hline $\mathrm{C}$ & -0.699370 & 2.344803 & .717768 \\
\hline $\mathrm{H}$ & 0.042073 & 2.864871 & -1.118469 \\
\hline $\mathrm{C}$ & -0.241987 & 1.121965 & -2.381912 \\
\hline $\mathrm{H}$ & -1.037897 & 0.619531 & -2.941143 \\
\hline $\mathrm{C}$ & 1.854739 & 0.094023 & -3.575569 \\
\hline $\mathrm{H}$ & 2.437732 & 0.275679 & -4.482841 \\
\hline $\mathrm{H}$ & 1.208068 & $-0.772854-$ & 3.757739 \\
\hline $\mathrm{C}$ & 1.006619 & 1.335446 & -3.232006 \\
\hline $\mathrm{H}$ & 1.648569 & 2.081888 & -2.755344 \\
\hline $\mathrm{H}$ & 0.643727 & 1.777074 & -4.172191 \\
\hline $\mathrm{C}$ & -0.078683 & $-4.035473-1$ & .555191 \\
\hline $\mathrm{C}$ & $0.226751-$ & $-5.537452-$ & 1.680393 \\
\hline $\mathrm{C}$ & 0.175293 & $-3.302565-2$ & 2.881813 \\
\hline $\mathrm{H}$ & $-1.146125-$ & $-3.928800-1$ & 1.338219 \\
\hline $\mathrm{H}$ & 0.036167 & $-6.062636-$ & 0.737637 \\
\hline $\mathrm{H}$ & $-0.396280-$ & $-5.992147-2$ & 2.458919 \\
\hline $\mathrm{H}$ & 1.275069 & $-5.709949-$ & 1.948120 \\
\hline $\mathrm{H}$ & $-0.134766-$ & 255512 & 2.796472 \\
\hline $\mathrm{H}$ & 1.237657 & $-3.314755-$ & 3.149768 \\
\hline $\mathrm{H}$ & $-0.388523-$ & -3.772204 & 3.696764 \\
\hline $\mathrm{C}$ & 0.108350 & -1.662532 & 2.985050 \\
\hline $\mathrm{C}$ & 0.736459 & -0.374033 & 3.530169 \\
\hline $\mathrm{C}$ & 0.099276 & -2.750436 & 4.078047 \\
\hline $\mathrm{H}$ & $-0.931153-$ & -1.438166 & 2.730534 \\
\hline $\mathrm{H}$ & 0.833556 & 0.391221 & 2.760703 \\
\hline $\mathrm{H}$ & 0.111325 & 0.024099 & 4.336752 \\
\hline $\mathrm{H}$ & 1.734425 & -0.555365 & 3.947132 \\
\hline $\mathrm{H}$ & $-0.370435-$ & -3.677492 & 3.733435 \\
\hline $\mathrm{H}$ & 1.123244 & -2.993090 & 4.385323 \\
\hline $\mathrm{H}$ & -0.446369 & 398534 & 4.960866 \\
\hline
\end{tabular}

$$
\begin{array}{cccc}
\text { C } & 4.371161 & -3.072946 & 0.684184 \\
\mathrm{C} & 5.017668 & -3.414464 & -0.662736 \\
\mathrm{C} & 4.736306 & -4.134021 & 1.741343 \\
\mathrm{H} & 4.784873 & -2.112525 & 1.011273 \\
\mathrm{H} & 4.703028 & -2.724767 & -1.450852 \\
\mathrm{H} & 6.108341 & -3.359280 & -0.578089 \\
\mathrm{H} & 4.767774 & -4.434259 & -0.980729 \\
\mathrm{H} & 4.333537 & -3.874445 & 2.726006 \\
\mathrm{H} & 4.330277 & -5.113288 & 1.460175 \\
\mathrm{H} & 5.824599 & -4.229610 & 1.831749 \\
\mathrm{C} & 3.756673 & 3.597364 & 1.588397 \\
\mathrm{~F} & 4.001123 & 4.820026 & 1.105807 \\
\mathrm{~F} & 3.531976 & 3.687995 & 2.905308 \\
\mathrm{~F} & 4.841717 & 2.830504 & 1.392464 \\
\mathrm{~S} & 2.294664 & 2.840710 & 0.731120 \\
\mathrm{O} & 1.155684 & 3.714612 & 1.064209 \\
\mathrm{O} & 2.226309 & 1.486446 & 1.387200 \\
\mathrm{O} & 2.687391 & 2.766406 & -0.689192 \\
\mathrm{Li} & 3.049240 & 0.207794 & 0.312860
\end{array}
$$

\section{L12-Ea}

$\begin{array}{lccc}\text { Atom } & \mathrm{X} & \mathrm{Y} & \mathrm{Z} \\ \mathrm{O} & -6.105495 & -4.455012 & -1.666513 \\ \mathrm{O} & -5.519118 & -3.135299 & 0.065058 \\ \mathrm{C} & -3.113023 & 3.573034 & -1.120896 \\ \mathrm{H} & -3.576557 & 3.127248 & -0.246401 \\ \mathrm{C} & -3.444253 & 4.866530 & -1.516547 \\ \mathrm{H} & -4.159540 & 5.440026 & -0.935177 \\ \mathrm{C} & -2.852861 & 5.423495 & -2.652094 \\ \mathrm{H} & -3.103264 & 6.435855 & -2.955705 \\ \mathrm{C} & -1.935863 & 4.676362 & -3.402169 \\ \mathrm{H} & -1.475347 & 5.110060 & -4.285236 \\ \mathrm{C} & -1.616228 & 3.378638 & -3.020526 \\ \mathrm{H} & -0.905641 & 2.801956 & -3.603075 \\ \mathrm{C} & -2.198703 & 2.809791 & -1.872369 \\ \mathrm{C} & -1.320873 & -0.885417 & -1.571184 \\ \mathrm{H} & -1.897810 & -1.028328 & -0.658076 \\ \mathrm{C} & -1.125963 & -2.146344 & -2.380072 \\ \mathrm{C} & -3.850821 & -3.929790 & -1.467168 \\ \mathrm{H} & -3.740860 & -4.489367 & -2.387980 \\ \mathrm{C} & -5.168757 & -3.789016 & -0.938945 \\ \mathrm{C} & -7.454327 & -4.318112 & -1.214061 \\ \mathrm{H} & -7.762649 & -3.268548 & -1.210052 \\ \mathrm{H} & -7.572631 & -4.720433 & -0.203551\end{array}$



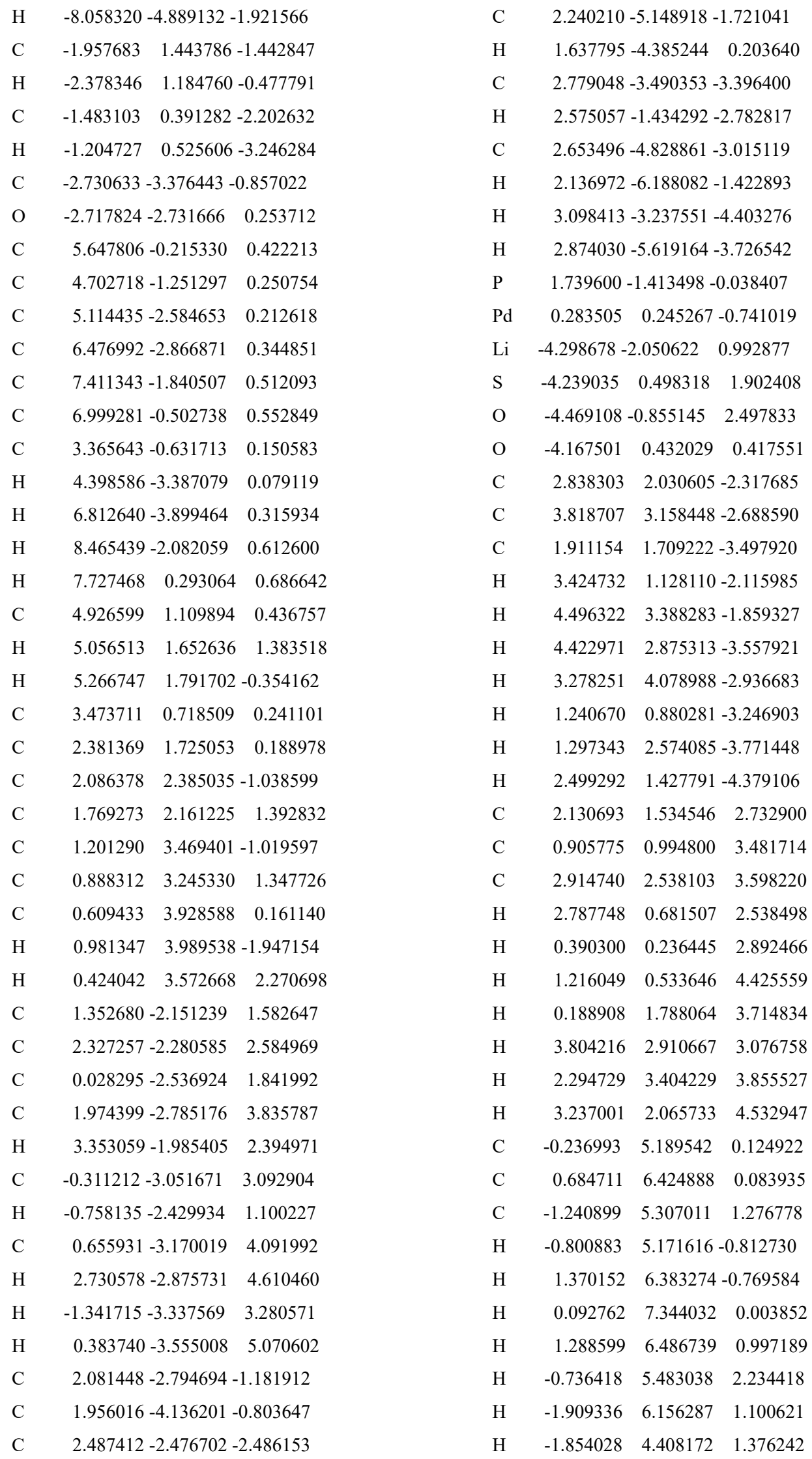


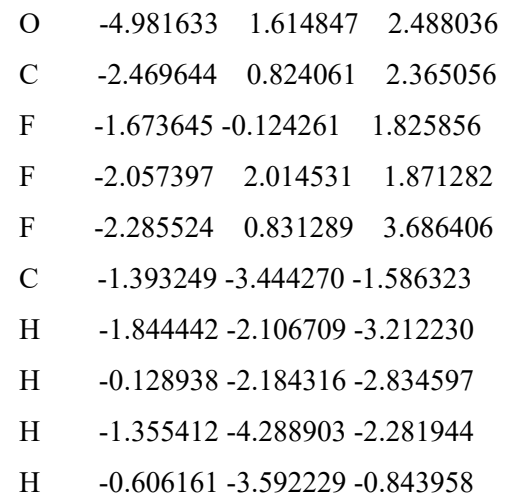

\section{L12-Eb}

\begin{tabular}{|c|c|c|c|}
\hline Atom & $\mathrm{X}$ & Y & $Z$ \\
\hline $\mathrm{C}$ & -2.764886 & 4.756730 & 0.491372 \\
\hline $\mathrm{C}$ & -1.419735 & 4.331863 & 0.546159 \\
\hline $\mathrm{C}$ & -0.389076 & 5.248049 & 0.761047 \\
\hline $\mathrm{C}$ & -0.721399 & 6.596567 & 0.916988 \\
\hline $\mathrm{C}$ & -2.053699 & 7.018550 & 0.860878 \\
\hline $\mathrm{C}$ & -3.087656 & 6.097460 & 0.649375 \\
\hline $\mathrm{C}$ & -1.394230 & 2.872030 & 0.341734 \\
\hline $\mathrm{H}$ & 0.644878 & 4.922600 & 0.802501 \\
\hline $\mathrm{H}$ & 0.066486 & 7.325351 & 1.082693 \\
\hline $\mathrm{H}$ & -2.289786 & 8.071548 & 0.983166 \\
\hline $\mathrm{H}$ & -4.121325 & 6.431242 & 0.610884 \\
\hline $\mathrm{C}$ & -3.648784 & 3.553414 & 0.266064 \\
\hline $\mathrm{H}$ & -4.316563 & 3.366184 & 1.120034 \\
\hline $\mathrm{H}$ & -4.300578 & 3.645142 & -0.611860 \\
\hline $\mathrm{C}$ & -2.655850 & 2.408480 & 0.138442 \\
\hline $\mathrm{C}$ & -3.104515 & 1.019722 & -0.158586 \\
\hline $\mathrm{C}$ & -3.558075 & $0.720518-$ & -1.479011 \\
\hline $\mathrm{C}$ & -3.284882 & 0.059423 & 0.875188 \\
\hline $\mathrm{C}$ & $-4.224180-0$ & $0.480291-1$ & 1.707056 \\
\hline $\mathrm{C}$ & $-3.971683-1$ & 1.132169 & 0.580962 \\
\hline $\mathrm{C}$ & $-4.488176-1$ & $.402242-0$ & 681914 \\
\hline $\mathrm{H}$ & $-4.579273-$ & $0.702511-2$ & 2.709089 \\
\hline $\mathrm{H}$ & -4.130683 & 1.838904 & 1.385798 \\
\hline $\mathrm{C}$ & -3.295373 & 1.691151 & -2.623959 \\
\hline $\mathrm{C}$ & -4.485247 & 1.836187 & -3.583529 \\
\hline $\mathrm{C}$ & -2.015693 & 1.292885 & -3.377660 \\
\hline $\mathrm{H}$ & -3.102321 & 2.677299 & -2.191187 \\
\hline $\mathrm{H}$ & -5.406600 & $2.081646-$ & -3.044152 \\
\hline $\mathrm{H}$ & -4.287632 & $2.634128-$ & -4.307336 \\
\hline $\mathrm{H}$ & -4.664150 & $0.918118-$ & -4.153985 \\
\hline $\mathrm{H}$ & -1.157566 & 1.28573 & -2.69964 \\
\hline
\end{tabular}

$\mathrm{H} \quad-2.114995 \quad 0.289476-3.808761$

$\mathrm{H} \quad-1.806472 \quad 1.995655-4.192542$

$\begin{array}{llll}\text { C } & -2.890256 & 0.340190 & 2.319274\end{array}$

C $\quad-2.039792-0.789326 \quad 2.920496$

$\begin{array}{llll}\text { C } & -4.138598 & 0.615051 & 3.176799\end{array}$

$\mathrm{H} \quad-2.281781 \quad 1.245759 \quad 2.335668$

H $\quad-1.164011-0.993626 \quad 2.295932$

H $\quad-1.680049-0.5020293 .913493$

$\mathrm{H} \quad-2.610901-1.719453 \quad 3.019721$

$\mathrm{H} \quad-4.725957 \quad 1.446080 \quad 2.769556$

$\mathrm{H} \quad-4.790952-0.264607 \quad 3.220706$

$\begin{array}{llll}\mathrm{H} & -3.846375 & 0.872807 & 4.200688\end{array}$

$\begin{array}{lllll}\text { C } & 0.411350 & 1.658283 & 2.241559\end{array}$

$\begin{array}{llll}\text { C } & -0.039896 & 2.623995 & 3.154854\end{array}$

$\begin{array}{llll}\text { C } & 1.177616 & 0.577701 & 2.697760\end{array}$

$\begin{array}{llll}\text { C } & 0.281943 & 2.502045 & 4.506091\end{array}$

$\begin{array}{llll}\mathrm{H} & -0.639803 & 3.462386 & 2.821731\end{array}$

$\begin{array}{llll}\text { C } & 1.523152 & 0.476805 & 4.045204\end{array}$

$\mathrm{H} \quad 1.522187-0.178057 \quad 2.004327$

$\begin{array}{llll}\text { C } & 1.067248 & 1.435238 & 4.951306\end{array}$

$\begin{array}{llll}\mathrm{H} & -0.074649 & 3.248884 & 5.210008\end{array}$

$\mathrm{H} \quad 2.153768-0.346254 \quad 4.364143$

$\begin{array}{llll}\mathrm{H} & 1.324666 & 1.353794 & 6.003560\end{array}$

C $\quad 1.401755 \quad 2.434350-0.419351$

C $\quad 2.705744 \quad 2.063316-0.059482$

C $\quad 1.188474 \quad 3.214933-1.565836$

C $\quad 3.782075 \quad 2.470243-0.844268$

$\begin{array}{llll}\mathrm{H} & 2.887282 & 1.431329 & 0.802316\end{array}$

C $\quad 2.275172 \quad 3.622817-2.340548$

$\mathrm{H} \quad 0.180157 \quad 3.502728-1.849605$

C $\quad 3.571752 \quad 3.243844-1.986550$

$\mathrm{H} \quad 4.781959 \quad 2.153236-0.571200$

$\mathrm{H} \quad 2.105495 \quad 4.227349-3.227125$

$\mathrm{H} \quad 4.416383 \quad 3.521649-2.608652$

O $\quad 6.327969 \quad 1.286181-2.807203$

O $\quad 5.933633-0.297442-1.245843$

C $\quad-2.437355-4.334921-1.918143$

H $\quad-2.577320-3.918746-2.912710$

C $\quad-3.080723-5.518340-1.562224$

H $\quad-3.733158-6.013843-2.275276$

C $\quad-2.882522-6.065869-0.294108$

H $\quad-3.382056-6.988244-0.013345$

C $\quad-2.047577-5.413407 \quad 0.619112$

$\mathrm{H} \quad-1.899213-5.827925 \quad 1.611928$ 


\begin{tabular}{|c|c|c|}
\hline $\mathrm{C}$ & $-1.400532-4.234192$ & 0.264432 \\
\hline $\mathrm{H}$ & $-0.750808-3.743015$ & 0.981697 \\
\hline $\mathrm{C}$ & $-1.570414-3.686128-$ & -1.022345 \\
\hline $\mathrm{C}$ & $-0.816795-2.519211-$ & -1.482350 \\
\hline $\mathrm{H}$ & $-1.130657-2.091602$ & -2.432355 \\
\hline $\mathrm{C}$ & $0.389647-2.117366$ & -0.923811 \\
\hline $\mathrm{H}$ & $0.778621-2.646952$ & -0.064774 \\
\hline $\mathrm{C}$ & $1.051486-0.905250$ & -1.295486 \\
\hline $\mathrm{H}$ & $1.901910-0.651053$ & -0.674452 \\
\hline $\mathrm{C}$ & $1.112298-0.381542$ & -2.709026 \\
\hline $\mathrm{H}$ & $1.335031 \quad 0.689032$ & -2.681144 \\
\hline $\mathrm{H}$ & $0.158725-0.510881$ & -3.228034 \\
\hline $\mathrm{C}$ & $2.218195-1.104433$ & -3.534087 \\
\hline $\mathrm{H}$ & $1.931197-2.152167$ & -3.673912 \\
\hline $\mathrm{H}$ & $2.281552-0.620502$ & -4.515023 \\
\hline $\mathrm{C}$ & $4.452378-0.052740$ & -3.116251 \\
\hline $\mathrm{H}$ & $4.263032 \quad 0.584971$ & -3.970457 \\
\hline $\mathrm{C}$ & $5.588217 \quad 0.242630$ & -2.318943 \\
\hline $\mathrm{C}$ & $\begin{array}{ll}7.488293 & 1.630767\end{array}$ & -2.048773 \\
\hline $\mathrm{H}$ & $8.172797 \quad 0.781666$ & $5-1.967577$ \\
\hline $\mathrm{H}$ & $\begin{array}{ll}7.222279 & 1.957311\end{array}$ & -1.038246 \\
\hline $\mathrm{H}$ & $7.962009 \quad 2.448486$ & -2.595352 \\
\hline $\mathrm{C}$ & $3.542216-1.060320$ & -2.785067 \\
\hline $\mathrm{O}$ & $3.657470-1.903681$ & -1.838899 \\
\hline $\mathrm{P}$ & $-0.012168 \quad 1.712304$ & 0.466088 \\
\hline $\mathrm{Pd}$ & $-0.799353-0.304138-$ & 0.366028 \\
\hline $\mathrm{Li}$ & $4.812729-1.576994-$ & 0.408393 \\
\hline $\mathrm{S}$ & $3.935913-1.960875$ & 1.982322 \\
\hline $\mathrm{O}$ & $3.348494-0.937065$ & 1.062830 \\
\hline $\mathrm{O}$ & $5.109639-2.601093$ & 1.327170 \\
\hline $\mathrm{O}$ & $4.054686-1.582383$ & 3.393206 \\
\hline $\mathrm{C}$ & $2.645606-3.301483$ & 1.983518 \\
\hline $\mathrm{F}$ & $2.536464-3.869489$ & 0.772737 \\
\hline $\mathrm{F}$ & $2.931106-4.249038$ & 2.876330 \\
\hline $\mathrm{F}$ & $1.432494-2.776034$ & 2.297325 \\
\hline $\mathrm{C}$ & $-5.367848-2.610120-$ & -0.971298 \\
\hline $\mathrm{C}$ & $-6.786566-2.144369-$ & -1.355991 \\
\hline $\mathrm{C}$ & $-5.438387-3.614296$ & 0.181871 \\
\hline $\mathrm{H}$ & $-4.938097-3.126719$ & -1.839276 \\
\hline $\mathrm{H}$ & $-6.775489-1.466435-$ & -2.215428 \\
\hline $\mathrm{H}$ & $-7.416738-3.004309$ & -1.609588 \\
\hline $\mathrm{H}$ & $-7.254764-1.614632$ & -0.517908 \\
\hline $\mathrm{H}$ & $-4.445662-3.944002$ & 0.495493 \\
\hline $\mathrm{H}$ & $-5.953127-3.182396$ & 1.048984 \\
\hline
\end{tabular}

\section{L12-Fa}

\begin{tabular}{|c|c|c|c|}
\hline Atom & $\mathrm{X}$ & Y & Z \\
\hline $\mathrm{O}$ & -3.996302 & $3.136913-$ & -1.985247 \\
\hline $\mathrm{O}$ & -4.635005 & 1.261642 & -0.924695 \\
\hline $\mathrm{C}$ & -1.392118 & 4.581960 & 0.861790 \\
\hline $\mathrm{H}$ & -2.094430 & 4.013708 & 1.465564 \\
\hline $\mathrm{C}$ & -1.073970 & 5.891598 & 1.217827 \\
\hline $\mathrm{H}$ & -1.534207 & 6.336816 & 2.096096 \\
\hline $\mathrm{C}$ & -0.169322 & 6.627215 & 0.450756 \\
\hline $\mathrm{H}$ & 0.084228 & 7.646868 & 0.725517 \\
\hline $\mathrm{C}$ & 0.406284 & $6.034323-$ & -0.677526 \\
\hline $\mathrm{H}$ & 1.113051 & $6.595085-$ & .283518 \\
\hline $\mathrm{C}$ & 0.090799 & 4.725896 & -1.029922 \\
\hline $\mathrm{H}$ & 0.571274 & 4.275879 & .893215 \\
\hline $\mathrm{C}$ & -0.811983 & $3.966597-$ & -0.262021 \\
\hline $\mathrm{C}$ & -1.698522 & 0.742305 & -2.223204 \\
\hline $\mathrm{H}$ & -1.894857 & $0.088247-$ & -1.367766 \\
\hline $\mathrm{C}$ & $-1.146114-0$ & $0.098852-3$ & 3.391548 \\
\hline $\mathrm{C}$ & -3.124991 & 1.117182 & -2.802875 \\
\hline $\mathrm{H}$ & -2.969822 & 1.745699 & -3.687183 \\
\hline $\mathrm{C}$ & -4.007844 & 1.820317 & -1.821156 \\
\hline $\mathrm{C}$ & -4.675314 & $3.918291-$ & -0.977591 \\
\hline $\mathrm{H}$ & -4.224078 & 3.730056 & -0.001979 \\
\hline $\mathrm{H}$ & -5.736303 & 3.661668 & -0.952972 \\
\hline $\mathrm{H}$ & -4.525822 & $4.954808-$ & -1.274211 \\
\hline $\mathrm{C}$ & -1.159099 & 2.573747 & -0.573347 \\
\hline $\mathrm{H}$ & -1.933487 & 2.146678 & 0.061265 \\
\hline $\mathrm{C}$ & -0.863049 & $1.905189-$ & -1.774958 \\
\hline $\mathrm{H}$ & -0.360546 & $2.446244-$ & -2.576113 \\
\hline $\mathrm{C}$ & - & $0.290020-3$ & 3.207454 \\
\hline $\mathrm{O}$ & -4.583126 & $.845214-2$ & 2.876280 \\
\hline $\mathrm{C}$ & $5.113230-$ & -1.609315 & 1.705247 \\
\hline $\mathrm{C}$ & $4.635810-$ & -1.429742 & 0.387532 \\
\hline $\mathrm{C}$ & $5.439205-$ & -1.779208 - & 0.700532 \\
\hline $\mathrm{C}$ & $6.705669-$ & - & 0.457347 \\
\hline $\mathrm{C}$ & $7.169980-$ & -2.503964 & 0.847743 \\
\hline $\mathrm{C}$ & $6.371217-$ & -2.145845 & 1.940863 \\
\hline $\mathrm{C}$ & $3.278865-$ & -0.849998 & 0.468704 \\
\hline $\mathrm{H}$ & $5.103114-$ & $-1.618360-$ & 1.718076 \\
\hline $\mathrm{H}$ & 7.338182 & $-2.593249-$ & 1.297029 \\
\hline $\mathrm{H}$ & $8.157310-$ & -2.924548 & 1.015805 \\
\hline $\mathrm{H}$ & $6.734002-$ & -2.286316 & 2.956065 \\
\hline
\end{tabular}




\begin{tabular}{|c|c|c|}
\hline C & $4.059928-1.140334$ & 2.677547 \\
\hline $\mathrm{H}$ & $3.727242-1.937175$ & 3.354902 \\
\hline $\mathrm{H}$ & $4.409832-0.319770$ & 3.319948 \\
\hline $\mathrm{C}$ & $2.934332-0.674661$ & 1.774999 \\
\hline $\mathrm{C}$ & $1.660091-0.083529$ & 2.257253 \\
\hline $\mathrm{C}$ & $1.512161 \quad 1.329394$ & 2.253900 \\
\hline $\mathrm{C}$ & $0.588511-0.912023$ & 2.654326 \\
\hline $\mathrm{C}$ & $0.264241 \quad 1.869113$ & 2.605577 \\
\hline $\mathrm{C}$ & $-0.628781-0.322503$ & 3.012967 \\
\hline $\mathrm{C}$ & $-0.813052 \quad 1.061967$ & 2.986978 \\
\hline $\mathrm{H}$ & $0.139523 \quad 2.947626$ & 2.606758 \\
\hline $\mathrm{H}$ & $-1.460264-0.961582$ & 3.291059 \\
\hline $\mathrm{C}$ & $1.448687-2.055059-$ & -1.375745 \\
\hline $\mathrm{C}$ & $2.248165-3.071803-$ & -1.922074 \\
\hline $\mathrm{C}$ & $0.080456-2.294812-$ & -1.184534 \\
\hline $\mathrm{C}$ & $1.680515-4.289253-2$ & -2.294734 \\
\hline $\mathrm{H}$ & $3.312368-2.91422$ & -2.056061 \\
\hline $\mathrm{C}$ & $-0.488754-3.512819-1$ & 1.561388 \\
\hline $\mathrm{H}$ & $-0.538567-1.528307-0$ & 0.729597 \\
\hline $\mathrm{C}$ & $0.310813-4.508465-2$ & -2.122613 \\
\hline $\mathrm{H}$ & $2.308253-5.068699-$ & -2.717699 \\
\hline $\mathrm{H}$ & $-1.547100-3.680918-1$ & 1.401252 \\
\hline $\mathrm{H}$ & $-0.128444-5.457796-2$ & 2.416190 \\
\hline $\mathrm{C}$ & $3.196159 \quad 0.119636$ & -2.231378 \\
\hline $\mathrm{C}$ & $3.035215-0.323343-$ & -3.550334 \\
\hline $\mathrm{C}$ & $4.156670 \quad 1.107144$ & -1.957602 \\
\hline $\mathrm{C}$ & $3.830688 \quad 0.199363$ & -4.572599 \\
\hline $\mathrm{H}$ & $2.298172-1.086355-$ & -3.778737 \\
\hline $\mathrm{C}$ & 4.9527391 .621907 & -2.977096 \\
\hline $\mathrm{H}$ & $4.285066 \quad 1.464181$ & -0.939316 \\
\hline $\mathrm{C}$ & $4.792759 \quad 1.169017$ & -4.290031 \\
\hline $\mathrm{H}$ & $3.699715-0.157960-$ & -5.590474 \\
\hline $\mathrm{H}$ & $5.700979 \quad 2.375491$ & -2.747700 \\
\hline $\mathrm{H}$ & $5.414026 \quad 1.5706$ & .085382 \\
\hline $\mathrm{P}$ & $2.105157-0.416832-0$ & 0.861992 \\
\hline $\mathrm{Pd}$ & $0.534665 \quad 1.197337$ & -0.291129 \\
\hline $\mathrm{Li}$ & $-4.854678-0.652029-0$ & .868836 \\
\hline S & $-4.026805-2.204884$ & 0.884655 \\
\hline $\mathrm{O}$ & $-3.646675-2.248311$ & 2.296688 \\
\hline $\mathrm{O}$ & $-5.432233-1.780433$ & 0.571888 \\
\hline $\mathrm{C}$ & $2.721052 \quad 2.246535$ & 2.077762 \\
\hline $\mathrm{C}$ & $3.219332 \quad 2.697733$ & 3.464335 \\
\hline $\mathrm{C}$ & $2.469086 \quad 3.455793$ & 1.168940 \\
\hline $\mathrm{H}$ & $3.518658 \quad 1.655500$ & 1.61 \\
\hline
\end{tabular}

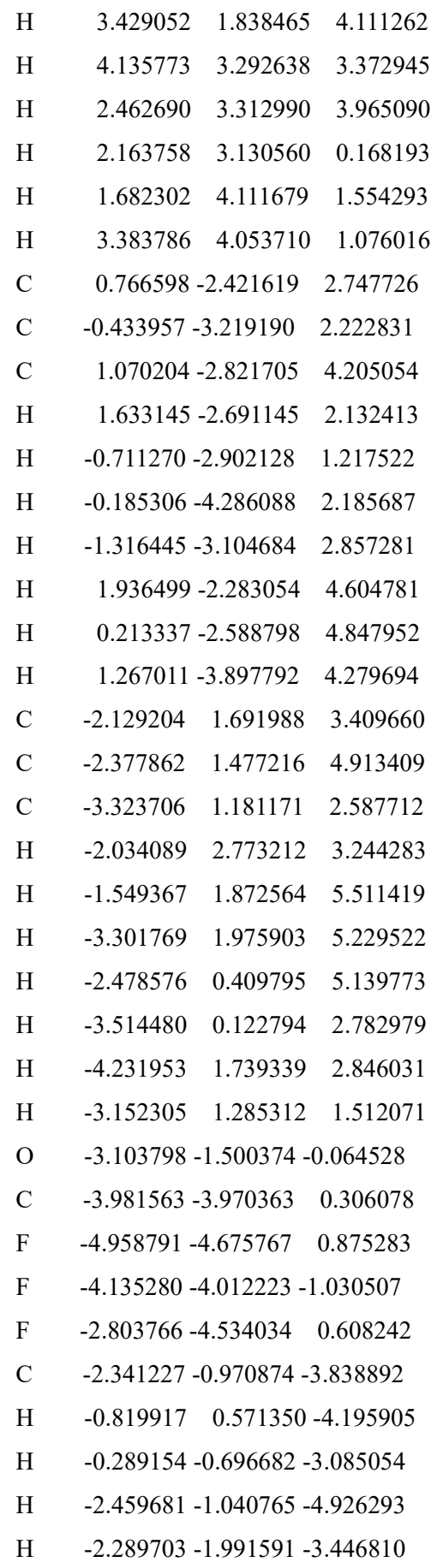

\section{L12-Fb}

$\begin{array}{lcccr}\text { Atom } & \mathrm{X} & \mathrm{Y} & \mathrm{Z} \\ \mathrm{C} & -4.331257 & 1.487610 & -2.804394 \\ \mathrm{C} & -4.321781 & 1.584820 & -1.395807 \\ \mathrm{C} & -5.162420 & 2.485652 & -0.739936 \\ \mathrm{C} & -6.012727 & 3.285799 & -1.508758 \\ \mathrm{C} & -6.022757 & 3.188296 & -2.903633\end{array}$




\begin{tabular}{|c|c|}
\hline $\mathrm{C}$ & $\begin{array}{llll}-5.179082 & 2.283863 & -3.561737\end{array}$ \\
\hline $\mathrm{C}$ & $-3.325192 \quad 0.630027-0.876054$ \\
\hline $\mathrm{I}$ & $\begin{array}{lll}-5.151676 & 2.568161 & 0.341753\end{array}$ \\
\hline $\mathrm{H}$ & $-6.671061 \quad 3.994994-1.015100$ \\
\hline $\mathrm{H}$ & $-6.689074 \quad 3.820890-3.483030$ \\
\hline $\mathrm{H}$ & $\begin{array}{llll}-5.190225 & 2.212291 & -4.646379\end{array}$ \\
\hline $\mathrm{C}$ & $-3.329740 \quad 0.439760-3.226468$ \\
\hline $\mathrm{H}$ & $-3.809956-0.419479-3.717726$ \\
\hline $\mathrm{H}$ & $-2.579581 \quad 0.811700-3.935514$ \\
\hline $\mathrm{C}$ & $-2.711746-0.006318-1.910951$ \\
\hline $\mathrm{C}$ & $-1.625240-1.019816-1.854390$ \\
\hline $\mathrm{C}$ & $-0.301663-0.642781-2.215023$ \\
\hline $\mathrm{C}$ & $-1.916477-2.373587-1.556810$ \\
\hline $\mathrm{C}$ & $0.674878-1.634265-2.315720$ \\
\hline $\mathrm{C}$ & $-0.895538-3.326414-1.674165$ \\
\hline $\mathrm{C}$ & $0.394799-2.984540-2.071481$ \\
\hline $\mathrm{H}$ & $1.688247-1.354306-2.584498$ \\
\hline $\mathrm{H}$ & $-1.131771-4.362692-1.460310$ \\
\hline $\mathrm{C}$ & $0.047992 \quad 0.825130-2.426739$ \\
\hline $\mathrm{C}$ & $1.045432 \quad 1.060954-3.570303$ \\
\hline $\mathrm{C}$ & $0.568135 \quad 1.453578-1.120495$ \\
\hline $\mathrm{H}$ & $-0.877760 \quad 1.351268-2.681498$ \\
\hline $\mathrm{H}$ & $0.709213 \quad 0.588947-4.500398$ \\
\hline $\mathrm{H}$ & $1.164930 \quad 2.133702-3.747162$ \\
\hline $\mathrm{H}$ & $2.038511 \quad 0.671879-3.323852$ \\
\hline $\mathrm{H}$ & $-0.078731 \quad 1.187629-0.277089$ \\
\hline $\mathrm{H}$ & $1.580073 \quad 1.104787-0.904960$ \\
\hline $\mathrm{H}$ & $0.615704 \quad 2.543122-1.205993$ \\
\hline $\mathrm{C}$ & $-3.320987-2.836428-1.195148$ \\
\hline $\mathrm{C}$ & $\begin{array}{lll}-3.343290 & -3.671313 & 0.094619\end{array}$ \\
\hline $\mathrm{C}$ & $-3.960335-3.602455-2.366744$ \\
\hline $\mathrm{H}$ & $-3.933578-1.950720-1.013799$ \\
\hline $\mathrm{H}$ & $-2.828042-3.141683 \quad 0.902169$ \\
\hline $\mathrm{H}$ & $-4.376531-3.855789 \quad 0.408754$ \\
\hline $\mathrm{H}$ & $-2.852740-4.641816-0.043506$ \\
\hline $\mathrm{H}$ & $-3.988961-2.987808-3.273798$ \\
\hline $\mathrm{H}$ & $-3.392568-4.510887-2.599204$ \\
\hline $\mathrm{H}$ & $-4.987095-3.897315-2.120538$ \\
\hline $\mathrm{C}$ & $-4.353118-0.599523 \quad 1.544234$ \\
\hline $\mathrm{C}$ & $-5.616399-0.596149 \quad 0.937543$ \\
\hline $\mathrm{C}$ & $-4.168515-1.331063 \quad 2.728402$ \\
\hline $\mathrm{C}$ & $-6.672531-1.308144 \quad 1.508451$ \\
\hline $\mathrm{H}$ & $-5.777599-0.044861 \quad 0.018476$ \\
\hline $\mathrm{C}$ & $-5.230146-2.022418 \quad 3.309335$ \\
\hline
\end{tabular}

\begin{tabular}{|c|c|c|}
\hline $\mathrm{H}$ & $-3.178796-1.373522$ & 79 \\
\hline C & $-6.485028-2.016692$ & 2.696261 \\
\hline $\mathrm{H}$ & $-7.644895-1.305214$ & 1.023807 \\
\hline $\mathrm{H}$ & $-5.073501-2.581671$ & 4.227499 \\
\hline $\mathrm{H}$ & $-7.310102-2.567861$ & 3.138369 \\
\hline C & $-2.811844 \quad 1.854168$ & 1.668536 \\
\hline $\mathrm{C}$ & $-3.313594 \quad 2.046470$ & 2.962664 \\
\hline $\mathrm{C}$ & $-2.114405 \quad 2.900748$ & 1.044821 \\
\hline $\mathrm{C}$ & $-3.112580 \quad 3.260130$ & 3.623074 \\
\hline $\mathrm{H}$ & $-3.866923 \quad 1.251543$ & 3.452663 \\
\hline $\mathrm{C}$ & $-1.917212 \quad 4.111109$ & 1.705905 \\
\hline $\mathrm{H}$ & $-1.728345 \quad 2.768173$ & 0.039717 \\
\hline $\mathrm{C}$ & $-2.410978 \quad 4.293426$ & 3.000040 \\
\hline $\mathrm{H}$ & $-3.510225 \quad 3.398128$ & 4.624911 \\
\hline $\mathrm{H}$ & $-1.376327 \quad 4.911822$ & 1.209676 \\
\hline $\mathrm{H}$ & $-2.254020 \quad 5.236142$ & 3.516124 \\
\hline $\mathrm{O}$ & $5.282143-1.719479$ & 2.727778 \\
\hline $\mathrm{O}$ & $5.354163 \quad 0.190774$ & 1.553070 \\
\hline $\mathrm{C}$ & $3.823630-1.608011-$ & 0.585413 \\
\hline $\mathrm{H}$ & $3.741838-0.578229-$ & 0.917442 \\
\hline $\mathrm{C}$ & $4.677322-2.482478-$ & 1.260842 \\
\hline $\mathrm{H}$ & $5.226656-2.126757-2$ & 2.127703 \\
\hline $\mathrm{C}$ & $4.824043-3.800515-$ & 0.823462 \\
\hline $\mathrm{H}$ & $5.488191-4.481828-$ & 1.347743 \\
\hline $\mathrm{C}$ & $4.102025-4.239366$ & 0.288501 \\
\hline $\mathrm{H}$ & $4.202469-5.264243$ & 0.634300 \\
\hline $\mathrm{C}$ & $3.252127-3.363819$ & 0.964246 \\
\hline $\mathrm{H}$ & $2.724805-3.714309$ & 1.845962 \\
\hline $\mathrm{C}$ & $3.105565-2.036968$ & 0.540000 \\
\hline $\mathrm{C}$ & $2.328819-1.015589$ & 1.351247 \\
\hline $\mathrm{H}$ & $2.192210-0.129383$ & 0.728249 \\
\hline $\mathrm{C}$ & $1.012945-1.504905$ & 1.913090 \\
\hline $\mathrm{H}$ & $0.971873-2.575347$ & 2.099687 \\
\hline $\mathrm{C}$ & $0.151912-0.706483$ & 2.702356 \\
\hline $\mathrm{H}$ & $-0.440842-1.229886$ & 3.454159 \\
\hline $\mathrm{C}$ & $0.365266 \quad 0.763390$ & 3.003115 \\
\hline $\mathrm{H}$ & $-0.498565 \quad 1.147892$ & 3.552589 \\
\hline $\mathrm{H}$ & $0.430085 \quad 1.358349$ & 2.087035 \\
\hline $\mathrm{C}$ & $1.648772 \quad 1.052098$ & 3.845603 \\
\hline $\mathrm{H}$ & $1.628780 \quad 2.085790$ & 4.200888 \\
\hline $\mathrm{H}$ & $1.699498 \quad 0.366598$ & 4.697977 \\
\hline $\mathrm{C}$ & $3.269400-0.518954$ & 2.594890 \\
\hline $\mathrm{H}$ & $3.072329-1.201808$ & 3.420822 \\
\hline C & $4.732413-0.611305$ & 2.23832 \\
\hline
\end{tabular}




$\begin{array}{llcc}\text { C } & 6.613870 & -2.025797 & 2.259426 \\ \text { H } & 7.304766 & -1.224037 & 2.526878 \\ \text { H } & 6.593463 & -2.156070 & 1.175643 \\ \text { H } & 6.882466 & -2.956423 & 2.757164 \\ \text { C } & 2.829393 & 0.891986 & 2.932728 \\ \text { O } & 3.307191 & 1.869200 & 2.358341 \\ \text { P } & -2.875957 & 0.222663 & 0.831749 \\ \text { Pd } & -0.877825 & -0.973538 & 0.884590 \\ \text { Li } & 4.576452 & 1.823878 & 0.874434 \\ \text { S } & 4.614993 & 2.871530 & -1.354855 \\ \text { O } & 3.866985 & 1.613715 & -1.009251 \\ \text { O } & 5.409353 & 3.273986 & -0.149334 \\ \text { O } & 5.269213 & 2.920396 & -2.657886 \\ \text { C } & 3.272496 & 4.153485 & -1.405888 \\ \text { F } & 2.553313 & 4.106949 & -0.269990 \\ \text { F } & 3.795909 & 5.375102 & -1.530987 \\ \text { F } & 2.443571 & 3.932650 & -2.437820 \\ \text { C } & 1.482600 & -4.022417 & -2.277519 \\ \text { C } & 1.634454 & -4.336573 & -3.778094 \\ \text { C } & 1.277043 & -5.310482 & -1.473405 \\ \text { H } & 2.419824 & -3.571202 & -1.942248 \\ \text { H } & 1.835430 & -3.427064 & -4.353957 \\ \text { H } & 2.460633 & -5.037962 & -3.945837 \\ \text { H } & 0.716653 & -4.788417 & -4.173844 \\ \text { H } & 1.115182 & -5.094467 & -0.412498 \\ \text { H } & 0.421553 & -5.889290 & -1.842273 \\ \text { H } & 2.164133 & -5.947421 & -1.556599\end{array}$

L12-TS1 (Imaginary frequency: $-221.5346 \mathrm{~cm}^{-1}$ )

$\begin{array}{lcrr}\text { Atom } & \mathrm{X} & \mathrm{Y} & \mathrm{Z} \\ \mathrm{C} & -3.441201 & -3.108433 & -0.149448 \\ \mathrm{H} & -3.797948 & -3.731648 & -0.961167 \\ \mathrm{C} & -2.372805 & -2.268486 & -0.379574 \\ \mathrm{C} & -4.217255 & -3.115608 & 1.071431 \\ \mathrm{O} & -4.044566 & -2.464555 & 2.092237 \\ \mathrm{O} & -5.292316 & -3.968664 & 0.943522 \\ \mathrm{C} & -6.150727 & -4.011654 & 2.080323 \\ \mathrm{H} & -6.934341 & -4.731266 & 1.834599 \\ \mathrm{H} & -6.589252 & -3.028446 & 2.281275 \\ \mathrm{H} & -5.606889 & -4.331997 & 2.974649 \\ \mathrm{O} & -1.737056 & -1.540252 & 0.481071 \\ \mathrm{C} & 0.673247 & 4.624345 & 0.458987 \\ \mathrm{C} & 1.496599 & 3.478606 & 0.524258 \\ \mathrm{C} & 2.861205 & 3.626770 & 0.794640\end{array}$

\begin{tabular}{|c|c|c|c|}
\hline $\mathrm{C}$ & 3.378277 & 4.910296 & 0.993507 \\
\hline $\mathrm{C}$ & 2.558017 & 6.038561 & 0.921669 \\
\hline $\mathrm{C}$ & 1.192133 & 5.896931 & 0.653217 \\
\hline $\mathrm{C}$ & 0.641182 & 2.286426 & 0.274397 \\
\hline 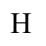 & 3.522985 & 2.772235 & 0.845138 \\
\hline $\mathrm{H}$ & 4.437865 & 5.026915 & 1.203095 \\
\hline $\mathrm{H}$ & 2.980064 & 7.027308 & 1.076733 \\
\hline $\mathrm{H}$ & 0.547119 & 6.770485 & 0.601536 \\
\hline $\mathrm{C}$ & -0.739355 & 4.195708 & 0.180692 \\
\hline $\mathrm{H}$ & -1.151095 & 4.627653 & -0.741687 \\
\hline $\mathrm{H}$ & -1.432223 & 4.481322 & 0.982835 \\
\hline $\mathrm{C}$ & -0.645632 & 2.685330 & 0.077350 \\
\hline $\mathrm{C}$ & -1.863863 & 1.884607 & -0.193523 \\
\hline $\mathrm{C}$ & -2.603611 & 1.324641 & 0.872415 \\
\hline $\mathrm{C}$ & -2.331200 & 1.772749 & -1.520963 \\
\hline $\mathrm{C}$ & -3.787807 & 0.647137 & 0.578643 \\
\hline $\mathrm{C}$ & -3.529631 & 1.095164 & -1.761948 \\
\hline $\mathrm{C}$ & -4.269260 & 0.518900 & -0.724962 \\
\hline $\mathrm{H}$ & -4.327152 & 0.157081 & 1.381925 \\
\hline $\mathrm{H}$ & -3.887763 & 1.012139 & -2.784130 \\
\hline $\mathrm{C}$ & 2.887708 & 0.685178 & -0.353931 \\
\hline $\mathrm{C}$ & 3.083157 & 1.325287 & -1.587302 \\
\hline $\mathrm{C}$ & 3.989045 & 0.172002 & 0.336923 \\
\hline $\mathrm{C}$ & 4.367158 & 1.476959 & -2.103479 \\
\hline $\mathrm{H}$ & 2.228908 & 1.722583 & -2.129355 \\
\hline $\mathrm{C}$ & 5.276445 & 0.326886 & -0.181622 \\
\hline $\mathrm{H}$ & 3.845466 & -0.343530 & 1.280072 \\
\hline $\mathrm{C}$ & 5.468759 & 0.982298 & -1.396991 \\
\hline $\mathrm{H}$ & 4.511711 & $1.987757-$ & -3.051248 \\
\hline $\mathrm{H}$ & 6.123437 & -0.086447 & 0.356597 \\
\hline $\mathrm{H}$ & 6.470956 & 1.103289 & -1.797988 \\
\hline $\mathrm{C}$ & 1.324767 & 0.080854 & 2.031680 \\
\hline $\mathrm{C}$ & $0.792920-$ & -1.147750 & 2.446645 \\
\hline $\mathrm{C}$ & 1.921404 & 0.932469 & 2.976447 \\
\hline $\mathrm{C}$ & $0.875224-$ & -1.528761 & 3.787023 \\
\hline $\mathrm{H}$ & $0.268197-$ & -1.775327 & 1.734261 \\
\hline $\mathrm{C}$ & 1.997230 & 0.547378 & 4.312757 \\
\hline $\mathrm{H}$ & 2.315428 & 1.895778 & 2.672829 \\
\hline $\mathrm{C}$ & 1.478808 & -0.685886 & 4.719019 \\
\hline $\mathrm{H}$ & 0.444389 & -2.474630 & 4.101097 \\
\hline $\mathrm{H}$ & 2.456777 & 1.212009 & 5.038848 \\
\hline $\mathrm{H}$ & 1.53505 & -0.980175 & 5.763281 \\
\hline $\mathrm{P}$ & 1.177526 & 0.539982 & 0.267774 \\
\hline Pd & \multicolumn{3}{|c|}{$-0.142764-0.980377-0.884665$} \\
\hline
\end{tabular}



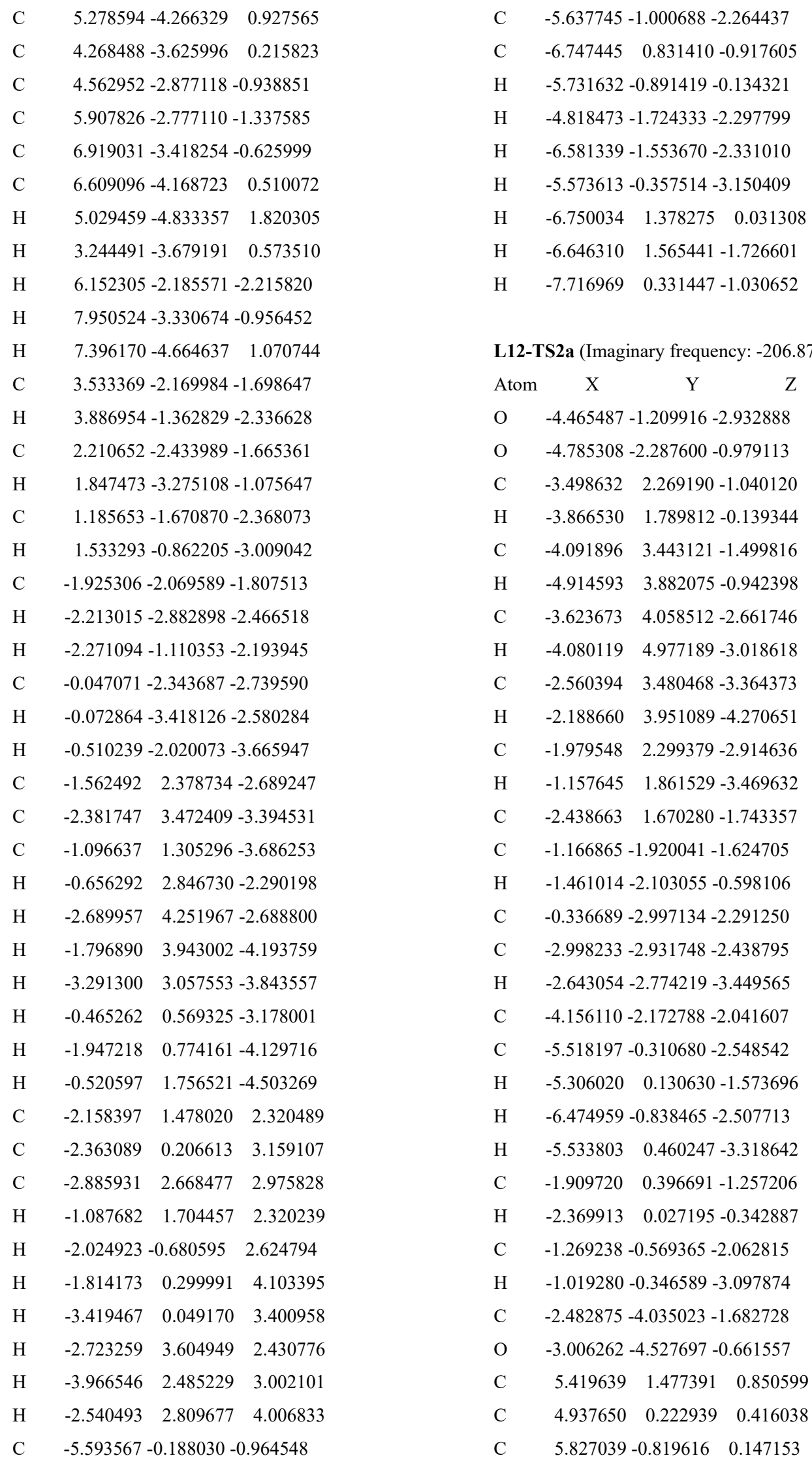

L12-TS2a (Imaginary frequency: -206.8766 $\mathrm{cm}^{-1}$ )

\begin{tabular}{|c|c|c|}
\hline Atom & $\mathrm{X}$ & Y \\
\hline $\mathrm{O}$ & $-4.465487-1$ & $1.209916-2.932888$ \\
\hline $\mathrm{O}$ & $-4.785308-2$ & $2.287600-0.979113$ \\
\hline $\mathrm{C}$ & -3.498632 & $2.269190-1.040120$ \\
\hline $\mathrm{H}$ & -3.866530 & $1.789812-0.139344$ \\
\hline $\mathrm{C}$ & -4.091896 & $3.443121-1.499816$ \\
\hline $\mathrm{H}$ & -4.914593 & $3.882075-0.942398$ \\
\hline $\mathrm{C}$ & -3.623673 & $4.058512-2.661746$ \\
\hline $\mathrm{H}$ & -4.080119 & $4.977189-3.018618$ \\
\hline $\mathrm{C}$ & -2.560394 & $3.480468-3.364373$ \\
\hline $\mathrm{H}$ & -2.188660 & $3.951089-4.270651$ \\
\hline $\mathrm{C}$ & -1.979548 & $2.299379-2.914636$ \\
\hline $\mathrm{H}$ & -1.157645 & $1.861529-3.469632$ \\
\hline $\mathrm{C}$ & -2.438663 & $1.670280-1.743357$ \\
\hline $\mathrm{C}$ & $-1.166865-1$ & $1.920041-1.624705$ \\
\hline $\mathrm{H}$ & $-1.461014-2$ & $2.103055-0.598106$ \\
\hline $\mathrm{C}$ & $-0.336689-2$ & $2.997134-2.291250$ \\
\hline $\mathrm{C}$ & $-2.998233-2$ & $2.931748-2.438795$ \\
\hline $\mathrm{H}$ & $-2.643054-2$ & $2.774219-3.449565$ \\
\hline $\mathrm{C}$ & $-4.156110-2$ & $2.172788-2.041607$ \\
\hline $\mathrm{C}$ & $-5.518197-0$ & $0.310680-2.548542$ \\
\hline $\mathrm{H}$ & -5.306020 & $0.130630-1.573696$ \\
\hline $\mathrm{H}$ & $-6.474959-($ & $0.838465-2.507713$ \\
\hline $\mathrm{H}$ & -5.533803 & $0.460247-3.318642$ \\
\hline $\mathrm{C}$ & -1.909720 & $0.396691-1.257206$ \\
\hline $\mathrm{H}$ & -2.369913 & $0.027195-0.342887$ \\
\hline $\mathrm{C}$ & $-1.269238-0$ & $0.569365-2.062815$ \\
\hline $\mathrm{H}$ & $-1.019280-($ & $0.346589-3.097874$ \\
\hline $\mathrm{C}$ & $-2.482875-4$ & $4.035023-1.682728$ \\
\hline $\mathrm{O}$ & $-3.006262-2$ & $4.527697-0.661557$ \\
\hline $\mathrm{C}$ & 5.419639 & $\begin{array}{ll}1.477391 & 0.850599\end{array}$ \\
\hline $\mathrm{C}$ & 4.937650 & $0.222939 \quad 0.416038$ \\
\hline $\mathrm{C}$ & $5.827039-$ & $-0.819616 \quad 0.147153$ \\
\hline
\end{tabular}




\begin{tabular}{|c|c|c|}
\hline $\mathrm{C}$ & $7.194573-0.599638$ & 0.337395 \\
\hline $\mathrm{C}$ & $7.667964 \quad 0.638065$ & 0.782343 \\
\hline $\mathrm{C}$ & $6.778146 \quad 1.688622$ & 1.040243 \\
\hline $\mathrm{C}$ & $3.469100 \quad 0.312874$ & 0.304714 \\
\hline $\mathrm{H}$ & $5.471061-1.777568-$ & -0.215629 \\
\hline $\mathrm{H}$ & $7.897796-1.401631$ & 0.131608 \\
\hline $\mathrm{H}$ & $8.734299 \quad 0.788684$ & 0.923773 \\
\hline $\mathrm{H}$ & $7.149745 \quad 2.652420$ & 1.379002 \\
\hline $\mathrm{C}$ & $4.251206 \quad 2.415265$ & 1.027831 \\
\hline $\mathrm{H}$ & $4.139209 \quad 2.756746$ & 2.066320 \\
\hline $\mathrm{H}$ & $4.333391 \quad 3.323888$ & 0.416863 \\
\hline $\mathrm{C}$ & $3.057298 \quad 1.570111$ & 0.616875 \\
\hline $\mathrm{C}$ & $1.686737 \quad 2.148702$ & 0.558658 \\
\hline $\mathrm{C}$ & $1.365147 \quad 3.021628$ & -0.519850 \\
\hline $\mathrm{C}$ & $0.788398 \quad 2.023893$ & 1.650873 \\
\hline $\mathrm{C}$ & $0.205402 \quad 3.790947$ & -0.444798 \\
\hline $\mathrm{C}$ & $-0.362054 \quad 2.825991$ & 1.673023 \\
\hline $\mathrm{C}$ & $-0.648879 \quad 3.743775$ & 0.664318 \\
\hline $\mathrm{H}$ & $-0.043276 \quad 4.458405$ & -1.265677 \\
\hline $\mathrm{H}$ & $-1.029473 \quad 2.739363$ & 2.521608 \\
\hline $\mathrm{C}$ & $2.128351-2.060957$ & 1.291787 \\
\hline $\mathrm{C}$ & $3.247922-2.464241$ & 2.039277 \\
\hline $\mathrm{C}$ & $0.850307-2.473649$ & 1.693161 \\
\hline $\mathrm{C}$ & $3.080087-3.268610$ & 3.164908 \\
\hline $\mathrm{H}$ & $4.242508-2.138435$ & 1.756189 \\
\hline $\mathrm{C}$ & $0.684365-3.271845$ & 2.825783 \\
\hline $\mathrm{H}$ & $-0.028138-2.136555$ & 1.156916 \\
\hline $\mathrm{C}$ & $1.800227-3.671535$ & 3.560350 \\
\hline $\mathrm{H}$ & $3.949205-3.572001$ & 3.742138 \\
\hline $\mathrm{H}$ & $-0.318932-3.536407$ & 3.143796 \\
\hline $\mathrm{H}$ & $1.675626-4.284447$ & 4.448627 \\
\hline $\mathrm{C}$ & $3.074217-1.90682$ & 158246 \\
\hline $\mathrm{C}$ & $3.282624-3.288622-$ & 1.362009 \\
\hline $\mathrm{C}$ & $3.460759-1.23327$ & 27883 \\
\hline $\mathrm{C}$ & $3.876411-3.984277-2$ & 2.418256 \\
\hline $\mathrm{H}$ & $2.990312-3.815968-$ & -0.459557 \\
\hline $\mathrm{C}$ & $4.062072-1.927874$ & 3.673887 \\
\hline $\mathrm{H}$ & $3.293111-0.162432-2$ & 2.711316 \\
\hline $\mathrm{C}$ & $4.269338-3.307234$ & 3.572601 \\
\hline $\mathrm{H}$ & $4.034166-5.055857$ & -2.334092 \\
\hline $\mathrm{H}$ & $4.368269-1.395656$ & -4.570133 \\
\hline $\mathrm{H}$ & $4.734141-3.84919$ & -4.391093 \\
\hline $\mathrm{P}$ & $2.238579-0.938841-0$ & 0.149782 \\
\hline $\mathrm{Pd}$ & $0.224207 \quad 0.155678$ & -0.630691 \\
\hline
\end{tabular}

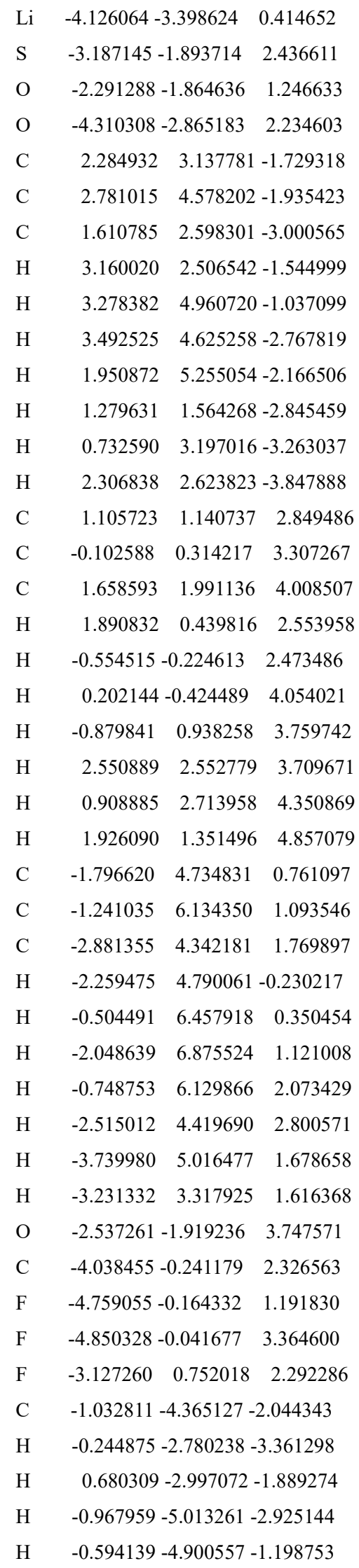




\begin{tabular}{|c|c|c|c|c|c|}
\hline \multicolumn{2}{|c|}{ L12-TS2b (Imaginary frequency: $-138.6955 \mathrm{~cm}^{-1}$ ) } & \multirow{2}{*}{$\begin{array}{l}\mathrm{H} \\
\mathrm{C}\end{array}$} & \multirow{2}{*}{$\begin{array}{l}5.979625 \\
3.469301\end{array}$} & \multicolumn{2}{|c|}{$3.977365-1.466557$} \\
\hline Atom & $\mathrm{Y}$ & & & 0.224562 & 2.056593 \\
\hline $\mathrm{C}$ & $4.843930-1.177505-2.354925$ & $\mathrm{C}$ & 4.856746 & 0.036863 & 1.967322 \\
\hline $\mathrm{C}$ & $4.312343-1.580265-1.108291$ & $\mathrm{C}$ & 2.950413 & 0.993488 & 3.107771 \\
\hline $\mathrm{C}$ & $4.757507-2.756188-0.499907$ & $\mathrm{C}$ & 5.705081 & 0.610708 & 2.914204 \\
\hline $\mathrm{C}$ & $5.732480-3.518824-1.150158$ & $\mathrm{H}$ & 5.274604 & -0.552278 & 1.158109 \\
\hline $\mathrm{C}$ & $6.254972-3.119450-2.383278$ & $\mathrm{C}$ & 3.799540 & 1.555357 & 4.061380 \\
\hline $\mathrm{C}$ & $5.811287-1.939662-2.994025$ & $\mathrm{H}$ & 1.880420 & 1.166880 & 3.155884 \\
\hline $\mathrm{C}$ & $3.321912-0.567623-0.688825$ & $\mathrm{C}$ & 5.179282 & 1.367925 & 3.963303 \\
\hline $\mathrm{H}$ & $4.354465-3.079612 \quad 0.452411$ & $\mathrm{H}$ & 6.778556 & 0.465919 & 2.831747 \\
\hline $\mathrm{H}$ & $6.084426-4.437519-0.689538$ & $\mathrm{H}$ & 3.385407 & 2.151790 & 4.869371 \\
\hline $\mathrm{H}$ & $7.009897-3.728103-2.872523$ & $\mathrm{H}$ & 5.843246 & 1.815103 & 4.697511 \\
\hline $\mathrm{H}$ & $6.220111-1.629645-3.952384$ & $\mathrm{C}$ & 2.051572 & -2.204846 & 1.330000 \\
\hline $\mathrm{C}$ & $4.196646 \quad 0.121044-2.771404$ & $\mathrm{C}$ & 2.575182 & 2.739614 & 2.513532 \\
\hline $\mathrm{H}$ & $4.923434 \quad 0.934528-2.903059$ & $\mathrm{C}$ & 1.228499 & -2.998749 & 0.517397 \\
\hline $\mathrm{H}$ & $3.654750 \quad 0.038433-3.723756$ & $\mathrm{C}$ & 2.288337 & -4.059568 & 2.869491 \\
\hline $\mathrm{C}$ & $3.243656 \quad 0.411715-1.631049$ & $\mathrm{H}$ & 3.210538 & -2.131508 & 3.149454 \\
\hline $\mathrm{C}$ & $2.323644 \quad 1.571541-1.541723$ & $\mathrm{C}$ & 0.955299 & -4.317996 & 0.868873 \\
\hline $\mathrm{C}$ & $0.959427 \quad 1.380371-1.899635$ & $\mathrm{H}$ & 0.790076 & $-2.581190-($ & 0.383126 \\
\hline $\mathrm{C}$ & $\begin{array}{llll}2.753834 & 2.788167 & -0.984449\end{array}$ & $\mathrm{C}$ & 1.484277 & -4.850562 & 2.047341 \\
\hline $\mathrm{C}$ & $0.043911 \quad 2.402804-1.600570$ & $\mathrm{H}$ & 2.696707 & -4.469041 & 3.789309 \\
\hline $\mathrm{C}$ & $1.811581 \quad 3.803266-0.770481$ & $\mathrm{H}$ & 0.316415 & -4.920362 & 0.232860 \\
\hline $\mathrm{C}$ & $0.455939 \quad 3.621421-1.038424$ & $\mathrm{H}$ & 1.262762 & -5.876373 & 2.327041 \\
\hline $\mathrm{H}$ & $-1.003247 \quad 2.272690-1.855210$ & $\mathrm{O}$ & -6.040828 & 1.495030 & 1.723791 \\
\hline $\mathrm{H}$ & $2.144447 \quad 4.746134-0.347066$ & $\mathrm{O}$ & -5.902860 & -0.443277 & 0.582452 \\
\hline $\mathrm{C}$ & $0.540013 \quad 0.179357-2.740276$ & $\mathrm{C}$ & -3.890537 & 1.556250 & -1.218674 \\
\hline $\mathrm{C}$ & $0.595779 \quad 0.568778-4.231180$ & $\mathrm{H}$ & -3.770222 & 0.543918 & -1.588648 \\
\hline $\mathrm{C}$ & $-0.834099-0.386963-2.383129$ & $\mathrm{C}$ & -4.526991 & 2.526019 & -1.993366 \\
\hline $\mathrm{H}$ & $1.275755-0.614382-2.575285$ & $\mathrm{H}$ & -4.889057 & 2.266432 & -2.983864 \\
\hline $\mathrm{H}$ & $1.583233 \quad 0.952059-4.512466$ & $\mathrm{C}$ & -4.705490 & 3.818465 & -1.496017 \\
\hline $\mathrm{H}$ & $0.367097-0.297781-4.861303$ & $\mathrm{H}$ & -5.204716 & 4.571878 & -2.098734 \\
\hline $\mathrm{H}$ & $\begin{array}{llll}-0.139618 & 1.351751 & -4.450528\end{array}$ & $\mathrm{C}$ & -4.251025 & 4.136939 & -0.212065 \\
\hline $\mathrm{H}$ & $-0.879698-0.678813-1.328932$ & $\mathrm{H}$ & -4.403034 & 5.135320 & 0.188100 \\
\hline $\mathrm{H}$ & $\begin{array}{llll}-1.636081 & 0.334658 & -2.561296\end{array}$ & $\mathrm{C}$ & -3.603127 & 3.176148 & 0.557511 \\
\hline $\mathrm{H}$ & $-1.058501-1.270424-2.985875$ & $\mathrm{H}$ & -3.270174 & 3.429086 & 1.558370 \\
\hline $\mathrm{C}$ & $4.214972 \quad 3.007877-0.618505$ & $\mathrm{C}$ & -3.396805 & 1.878656 & 0.058211 \\
\hline $\mathrm{C}$ & $\begin{array}{lll}4.399141 & 3.633132 & 0.772474\end{array}$ & $\mathrm{C}$ & -2.685893 & 0.846090 & 0.829408 \\
\hline $\mathrm{C}$ & $4.915680 \quad 3.851174-1.699094$ & $\mathrm{H}$ & -2.657651 & 0.124597 & 0.348519 \\
\hline $\mathrm{H}$ & $\begin{array}{llll}4.698673 & 2.025137 & -0.591086\end{array}$ & $\mathrm{C}$ & -1.609820 & 1.192726 & 1.700977 \\
\hline $\mathrm{H}$ & $\begin{array}{lll}3.872992 & 3.056026 & 1.536968\end{array}$ & $\mathrm{H}$ & -1.535142 & 2.227387 & 2.022623 \\
\hline $\mathrm{H}$ & $\begin{array}{lll}5.462230 & 3.656620 & 1.036339\end{array}$ & $\mathrm{C}$ & -0.806307 & 0.229095 & 2.375906 \\
\hline $\mathrm{H}$ & $\begin{array}{lll}4.029363 & 4.664446 & 0.805742\end{array}$ & $\mathrm{H}$ & -0.254791 & 0.610103 & 3.235985 \\
\hline $\mathrm{H}$ & $4.831375 \quad 3.383626-2.686494$ & $\mathrm{C}$ & -1.203512 & .221844 & 2.515332 \\
\hline
\end{tabular}




$\begin{array}{llll}\mathrm{H} & -0.393361 & -1.766555 & 3.008445 \\ \mathrm{H} & -1.356896 & -1.708892 & 1.548148 \\ \mathrm{C} & -2.514702 & -1.382408 & 3.354060 \\ \mathrm{H} & -2.552072 & -2.397344 & 3.758965 \\ \mathrm{H} & -2.519413 & -0.666920 & 4.183204 \\ \mathrm{C} & -4.250451 & 0.110026 & 2.237383 \\ \mathrm{H} & -4.055930 & 0.856776 & 2.996827 \\ \mathrm{C} & -5.455966 & 0.311389 & 1.456731 \\ \mathrm{C} & -7.126230 & 1.869962 & 0.861060 \\ \mathrm{H} & -7.942263 & 1.146744 & 0.931280 \\ \mathrm{H} & -6.780477 & 1.932046 & -0.173030 \\ \mathrm{H} & -7.448437 & 2.849341 & 1.215088 \\ \mathrm{C} & -3.714388 & -1.216243 & 2.442103 \\ \mathrm{O} & -4.095295 & -2.222683 & 1.809663 \\ \mathrm{P} & 2.303591 & -0.467296 & 0.821480 \\ \mathrm{Pd} & 0.284500 & 0.684925 & 0.622640 \\ \mathrm{Li} & -4.964448-2.063527 & 0.127917 \\ \mathrm{~S} & -3.618399 & -2.922438 & -1.809901\end{array}$

H $\quad-0.393361-1.766555 \quad 3.008445$

C $\quad-2.514702-1.382408 \quad 3.354060$

H $\quad-2.552072-2.397344 \quad 3.758965$

$\begin{array}{llll}\text { C } & -4.250451 & 0.110026 & 2.237383\end{array}$

$\mathrm{H} \quad-4.055930 \quad 0.856776 \quad 2.996827$

$\begin{array}{llll}\text { C } & -5.455966 & 0.311389 & 1.456731\end{array}$

$\begin{array}{llll}\text { C } & -7.126230 & 1.869962 & 0.861060\end{array}$

$-7.942263$

$\begin{array}{llll}\mathrm{H} & -7.448437 & 2.849341 & 1.215088\end{array}$

$-3.714388-1.216243 \quad 2.442103$

S $\quad-3.618399-2.922438-1.809901$ $\begin{array}{cccc}\text { O } & -3.391036 & -1.592561 & -1.155996 \\ \text { O } & -4.833813 & -3.543725 & -1.200373 \\ \text { O } & -3.473223 & -2.977939 & -3.262909 \\ \text { C } & -2.217789 & -3.951018 & -1.144826 \\ \text { F } & -2.127003 & -3.825250 & 0.187393 \\ \text { F } & -2.388099 & -5.241851 & -1.440896 \\ \text { F } & -1.047385 & -3.547232 & -1.680615 \\ \text { C } & -0.563886 & 4.705856 & -0.745254 \\ \text { C } & -0.340610 & 5.942551 & -1.631354 \\ \text { C } & -0.570681 & 5.086327 & 0.743781 \\ \text { H } & -1.551231 & 4.296596 & -0.984387 \\ \text { H } & -0.372376 & 5.676181 & -2.693227 \\ \text { H } & -1.113388 & 6.697251 & -1.443576 \\ \text { H } & 0.634207 & 6.402520 & -1.430142 \\ \text { H } & -0.711024 & 4.199963 & 1.370273 \\ \text { H } & 0.373859 & 5.557787 & 1.039287 \\ \text { H } & -1.380343 & 5.793660 & 0.957937\end{array}$

F $-2.127003-3.825250-0.187393$




\section{Copies of NMR-Spectra}<smiles>COC(=O)C=C1COC(=O)O1</smiles>

${ }^{1} \mathbf{H}$ NMR $\left(400 \mathrm{MHz}, \mathrm{CDCl}_{3}\right)$

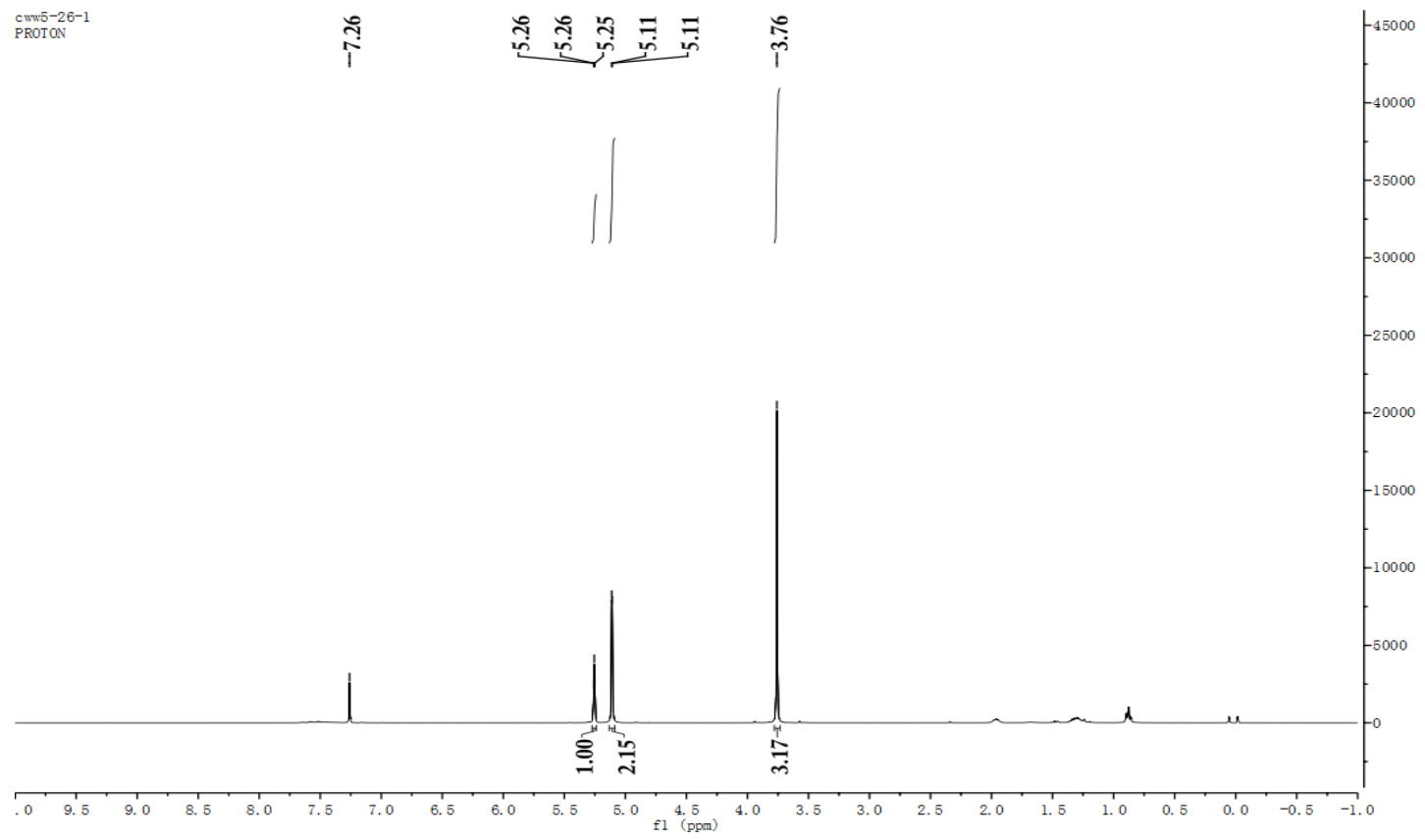

${ }^{13} \mathbf{C}$ NMR $\left(100 \mathrm{MHz}, \mathrm{CDCl}_{3}\right)$

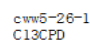

苍

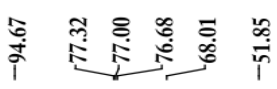

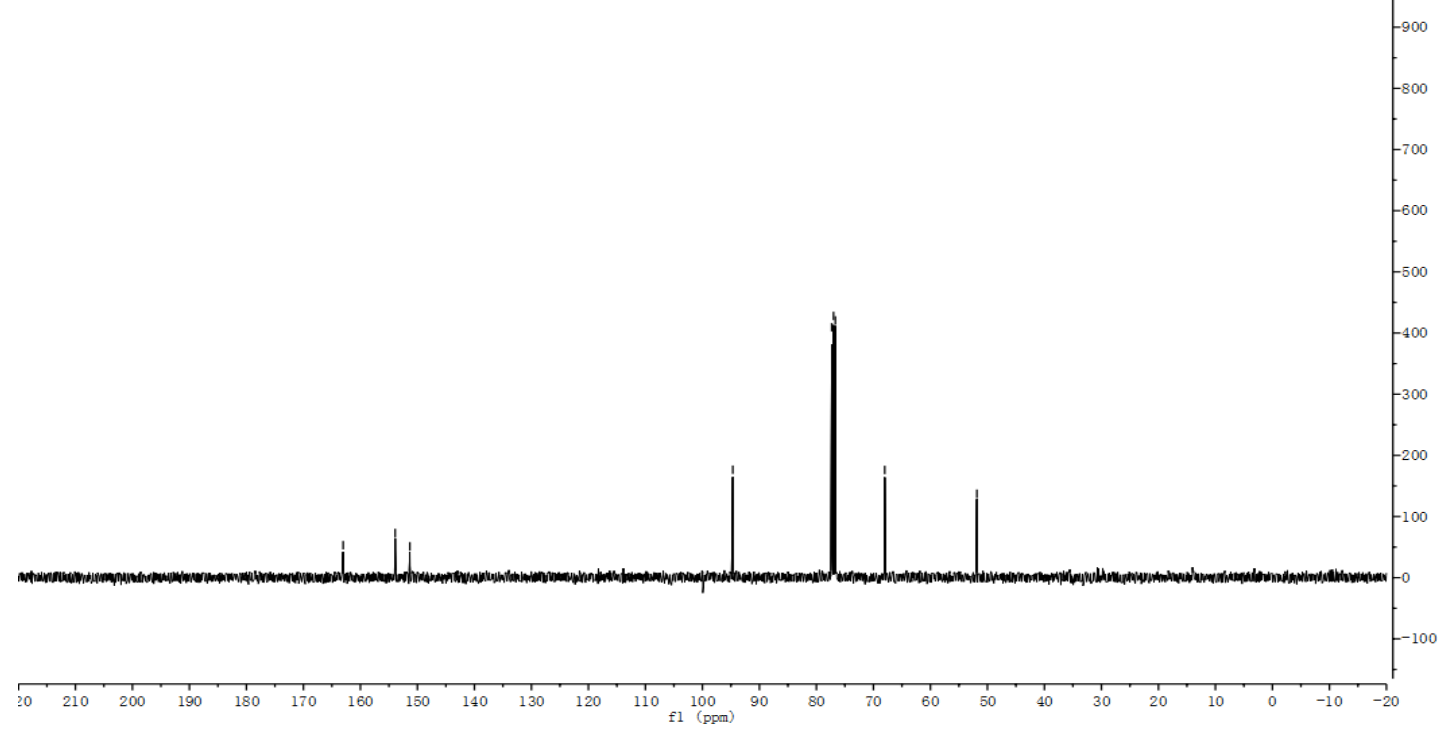


<smiles>CCOC(=O)C=C1COC(=O)O1</smiles>

${ }^{1} \mathbf{H}$ NMR $\left(400 \mathrm{MHz}, \mathrm{CDCl}_{3}\right)$

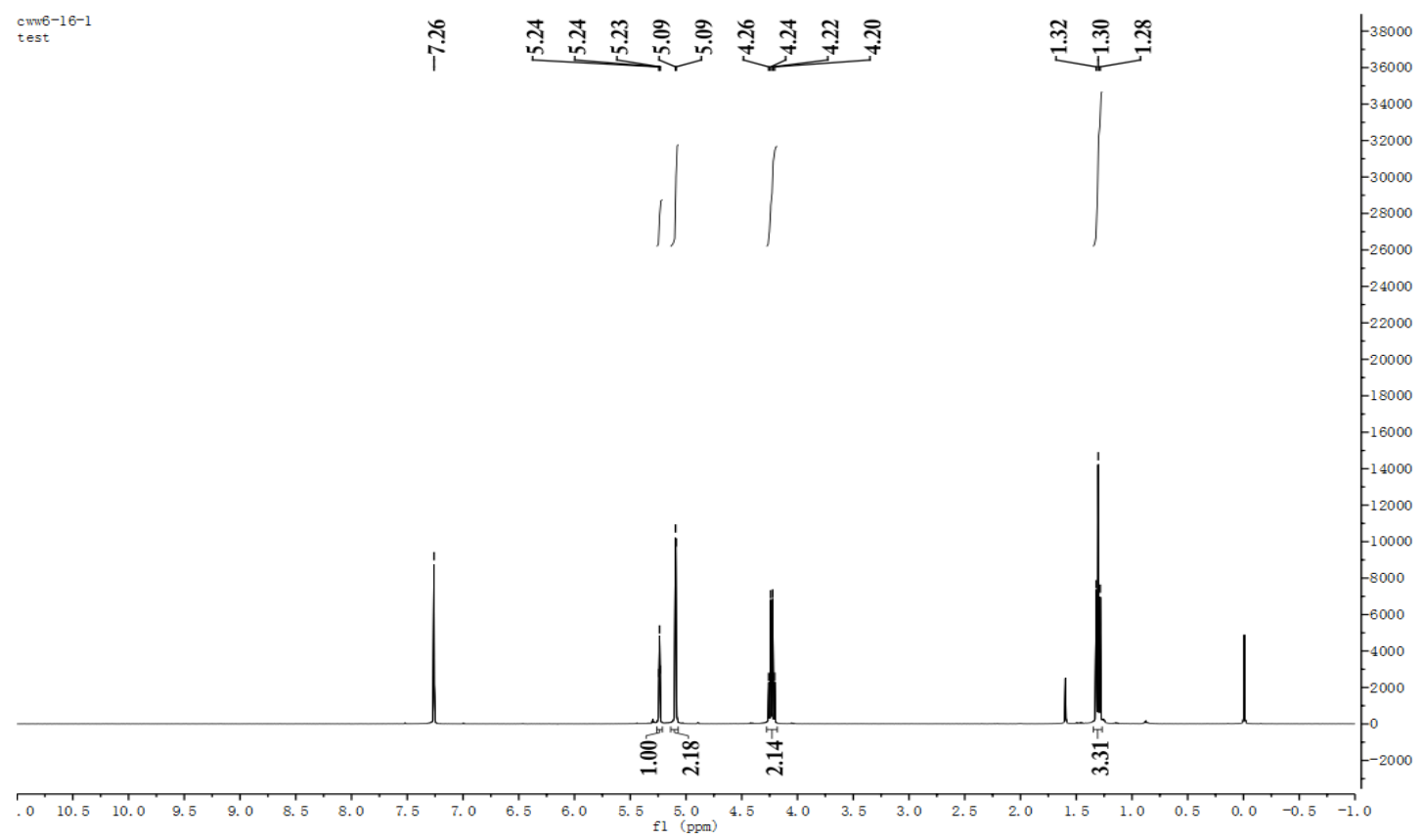

${ }^{13} \mathbf{C}$ NMR $\left(100 \mathrm{MHz}, \mathrm{CDCl}_{3}\right)$

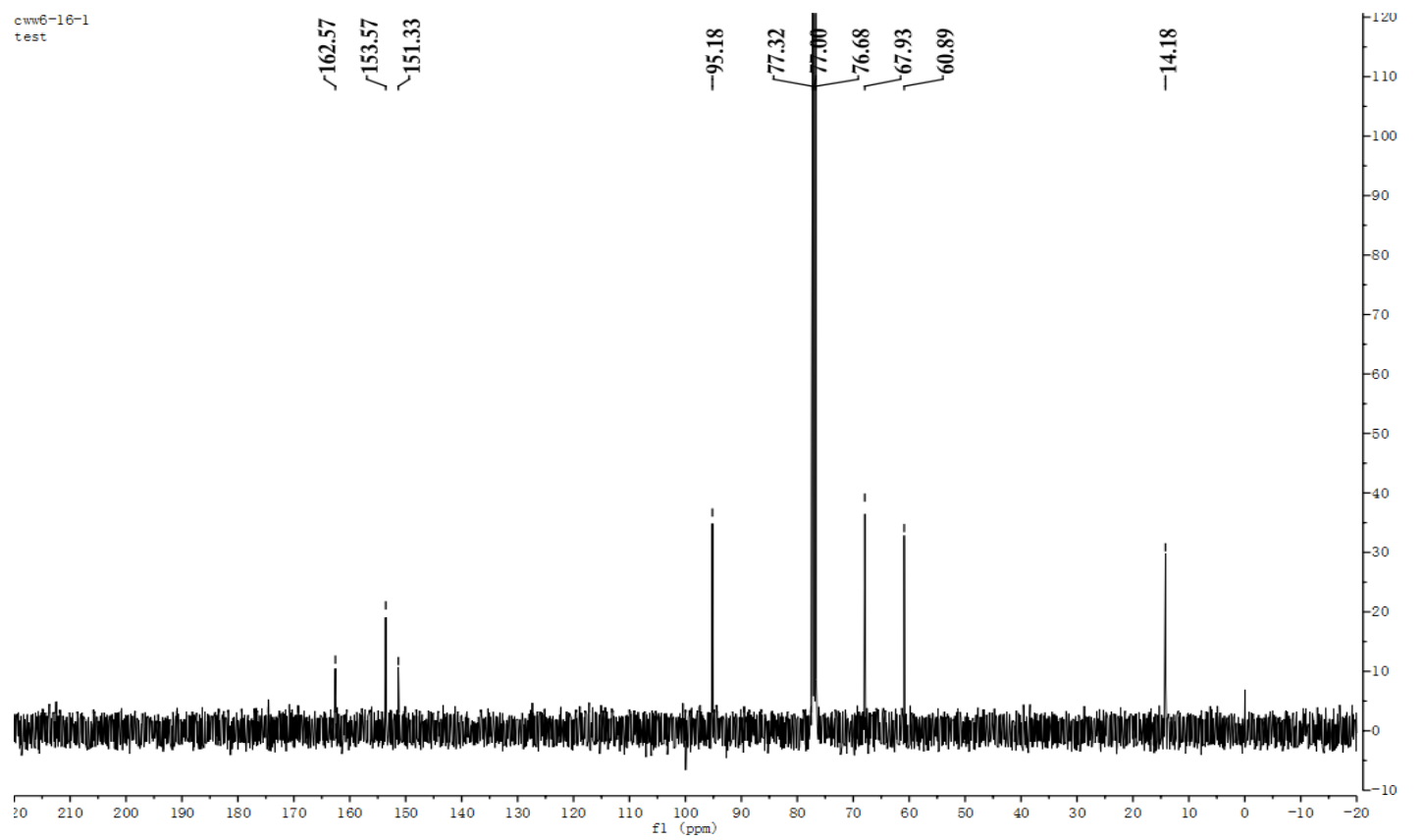




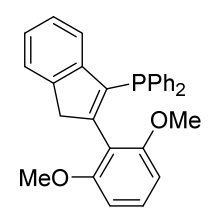

L11

${ }^{1} \mathbf{H}$ NMR $\left(400 \mathrm{MHz}, \mathrm{CDCl}_{3}\right)$

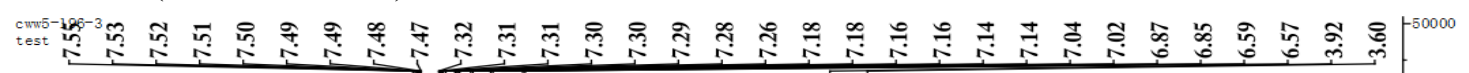
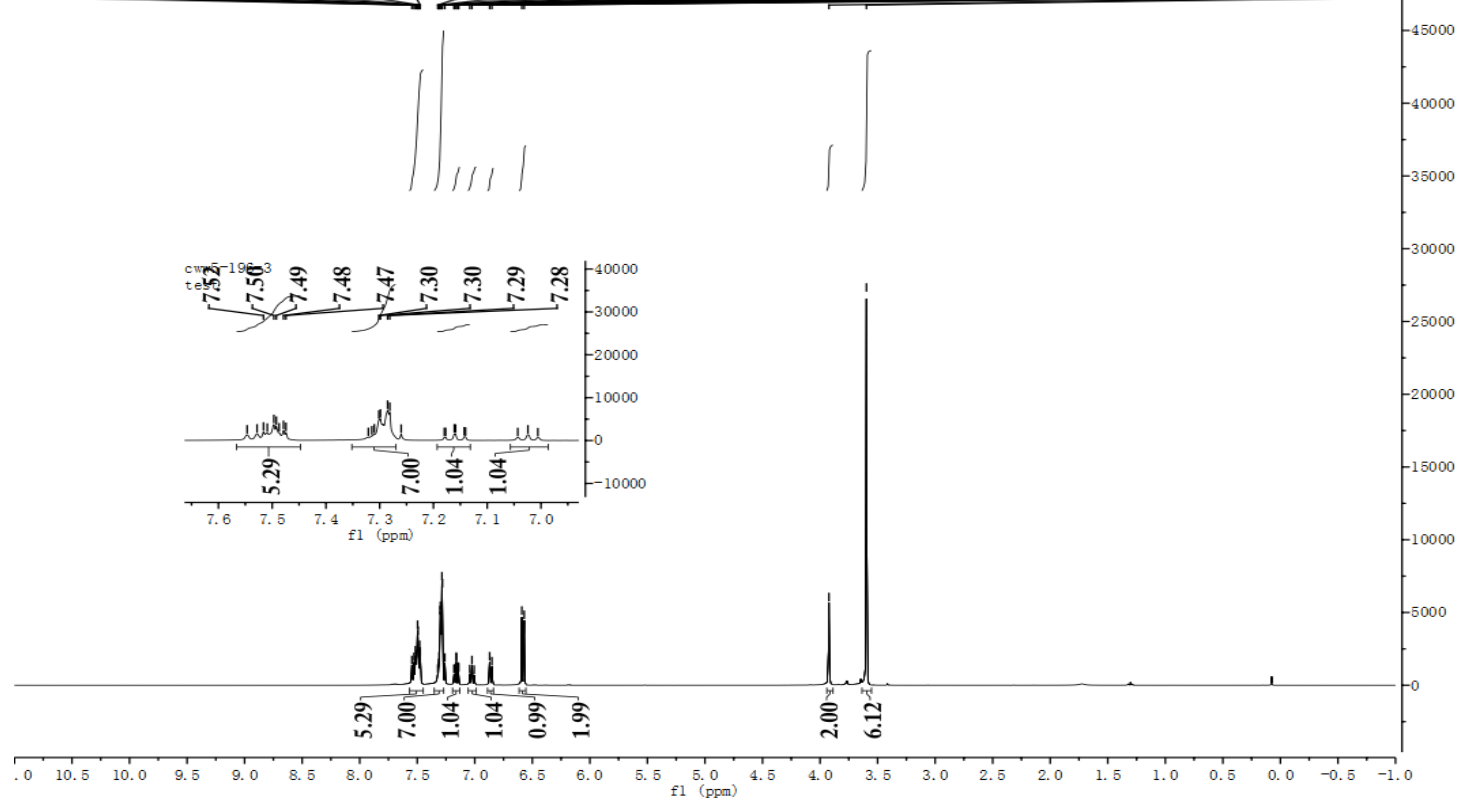

${ }^{13} \mathbf{C}$ NMR $\left(100 \mathrm{MHz}, \mathrm{CDCl}_{3}\right)$

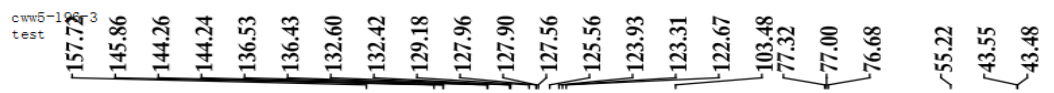

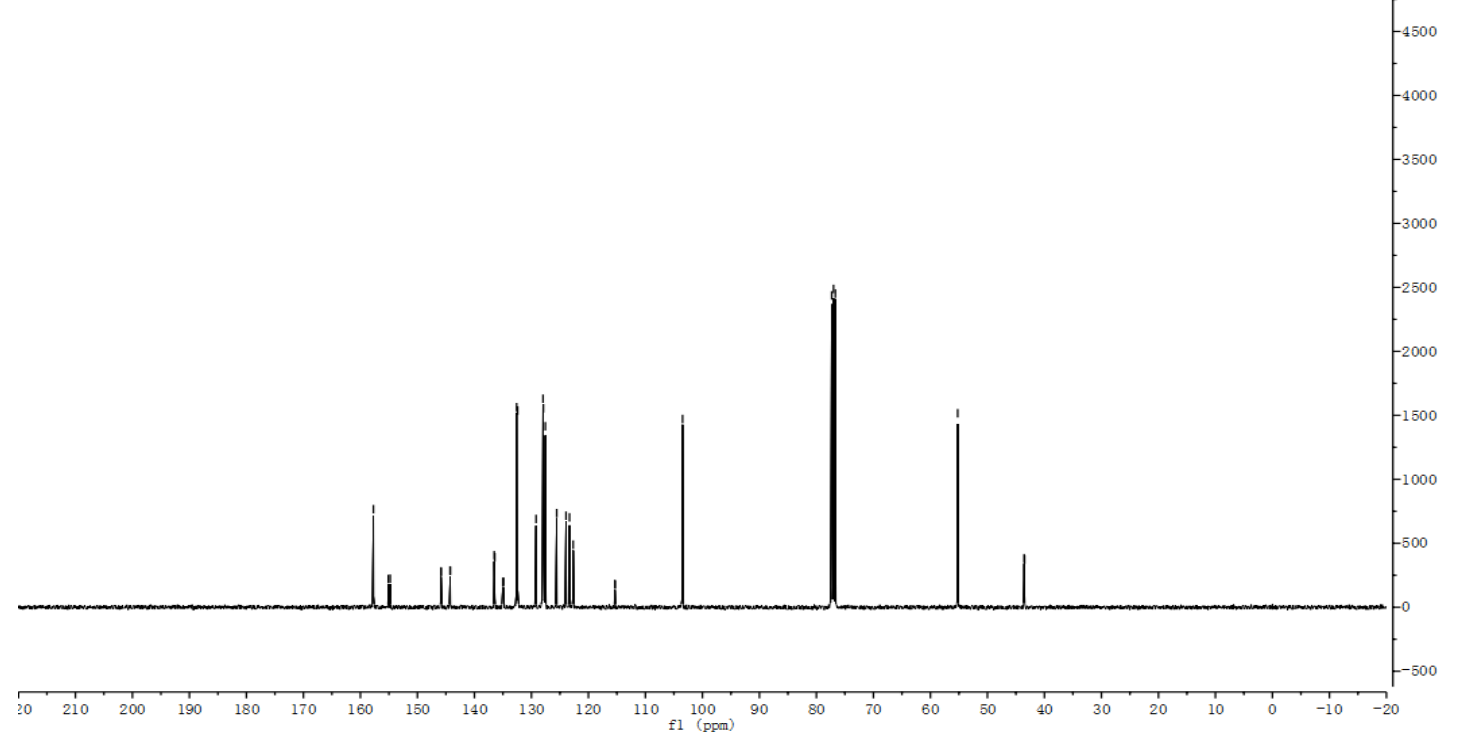


${ }^{31} \mathbf{P}$ NMR (162 MHz, $\left.\mathrm{CDCl}_{3}\right)$

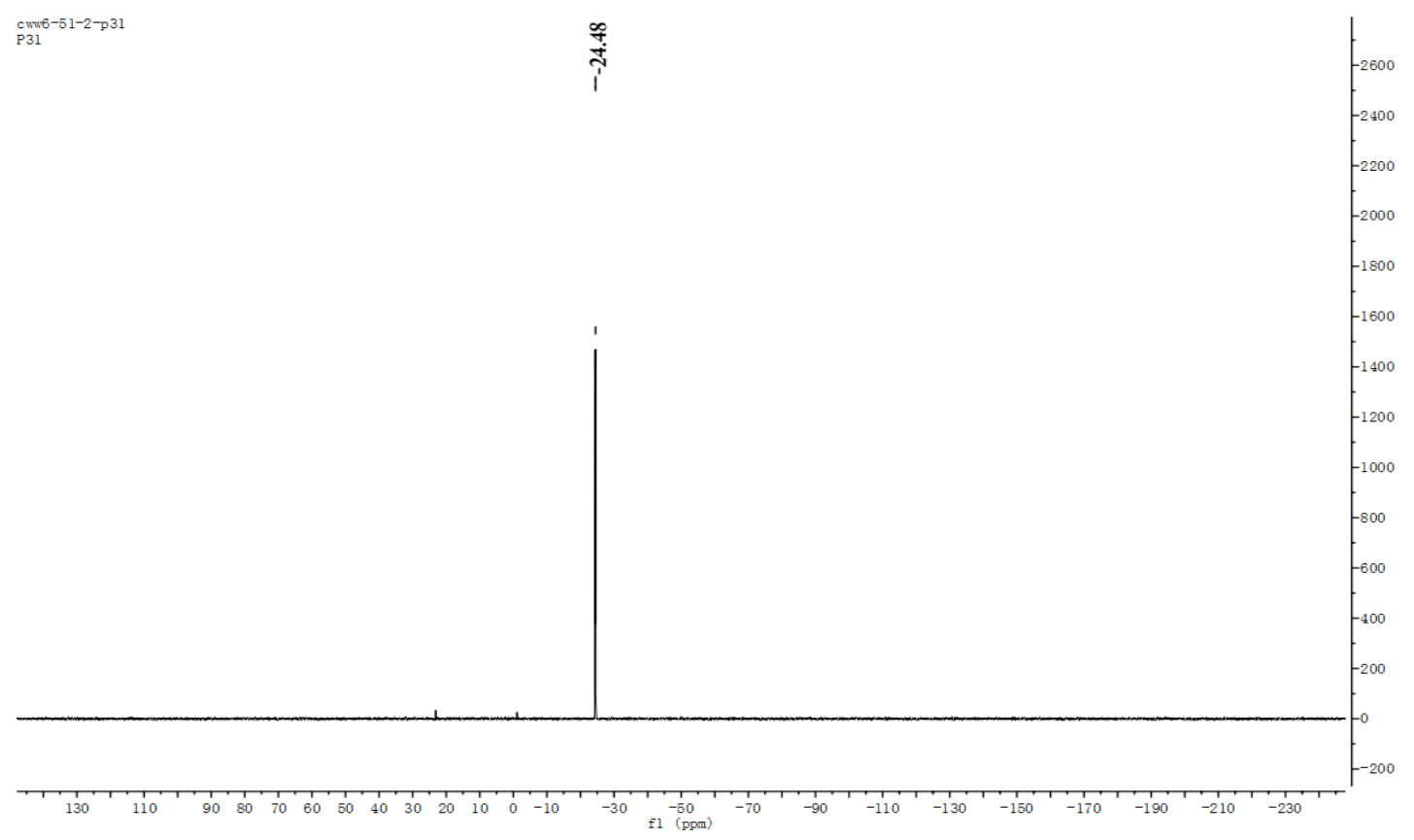




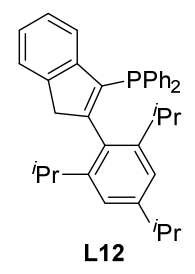

${ }^{1} \mathbf{H}$ NMR (400 MHz, $\left.\mathrm{CDCl}_{3}\right)$

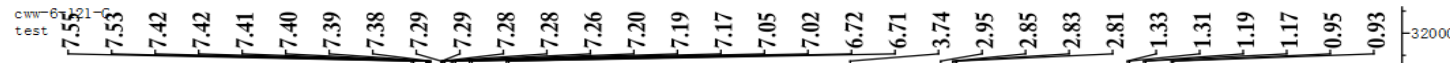

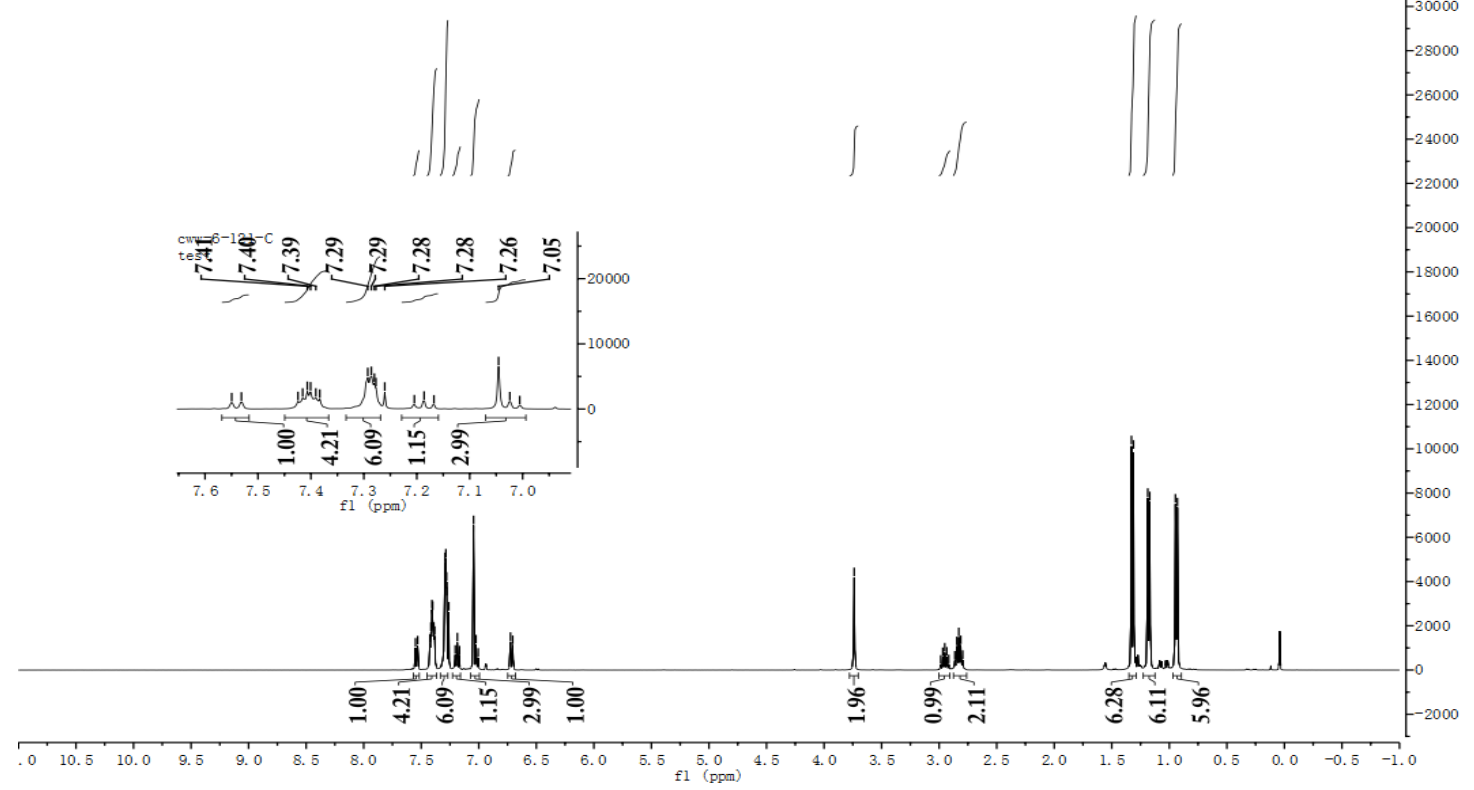

30000

${ }^{13} \mathbf{C}$ NMR (100 MHz, $\left.\mathrm{CDCl}_{3}\right)$

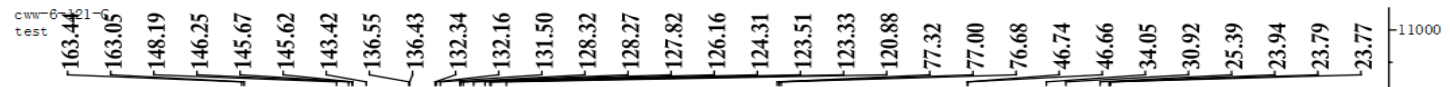

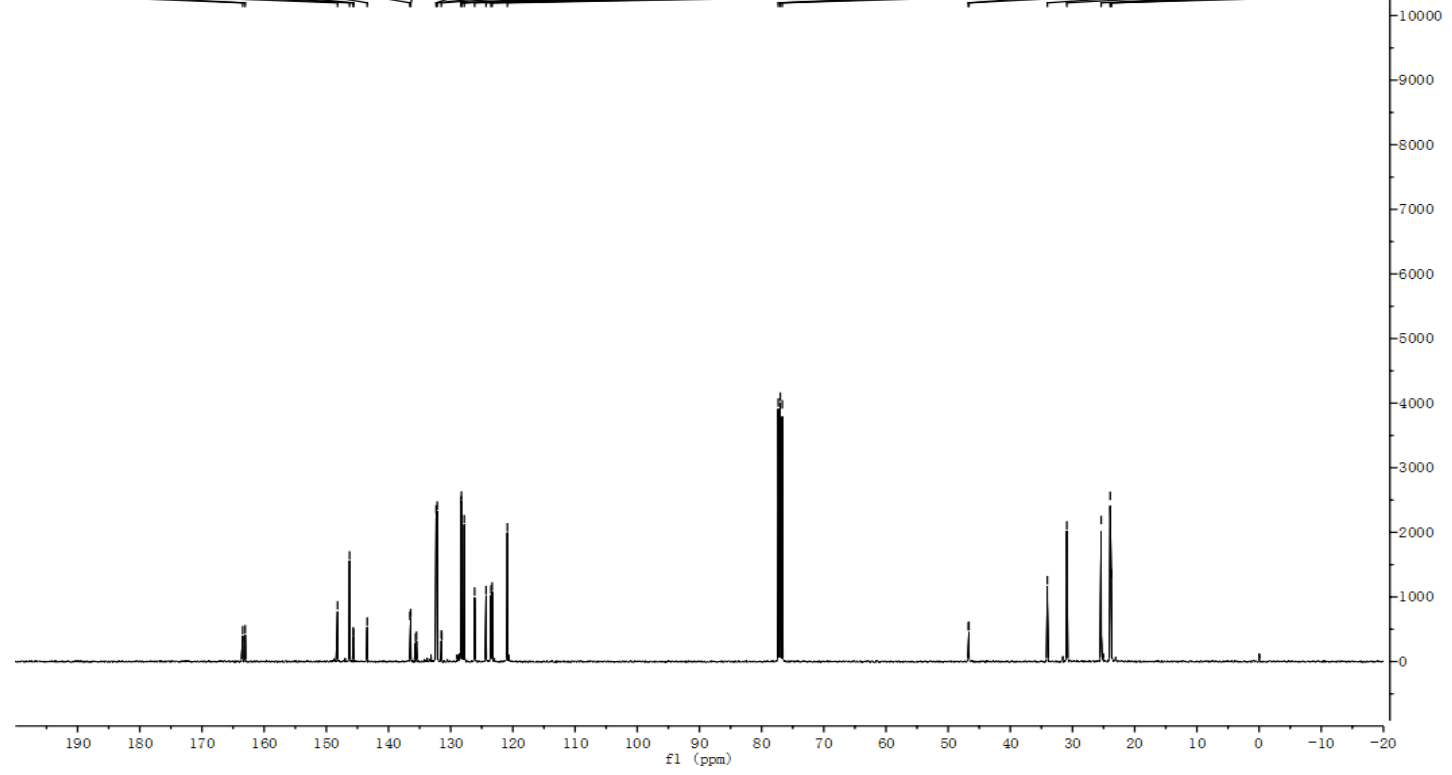


${ }^{31} \mathbf{P}$ NMR $\left(162 \mathrm{MHz}, \mathrm{CDCl}_{3}\right)$

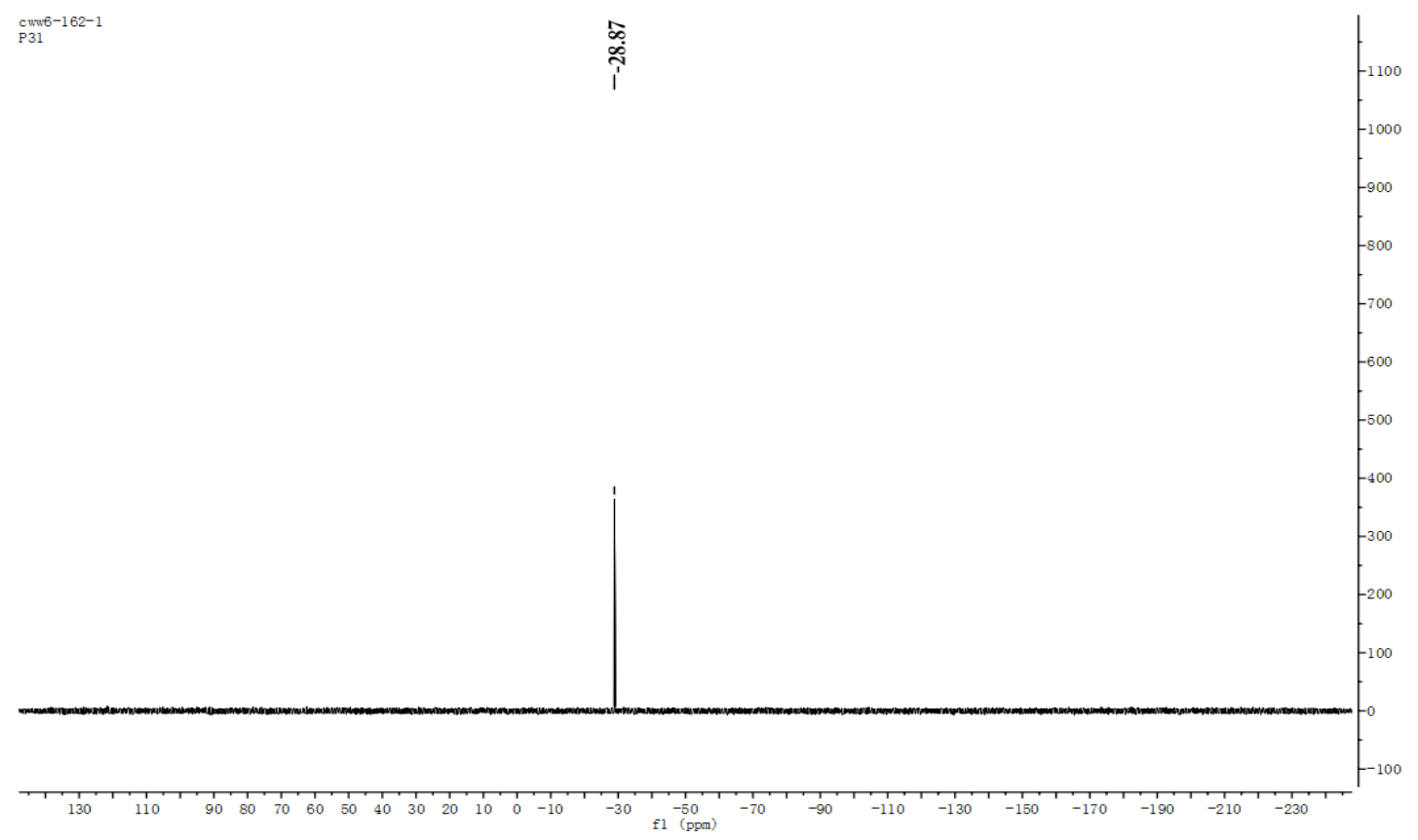




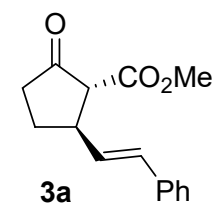

${ }^{1} \mathbf{H}$ NMR $\left(400 \mathrm{MHz}, \mathrm{CDCl}_{3}\right)$

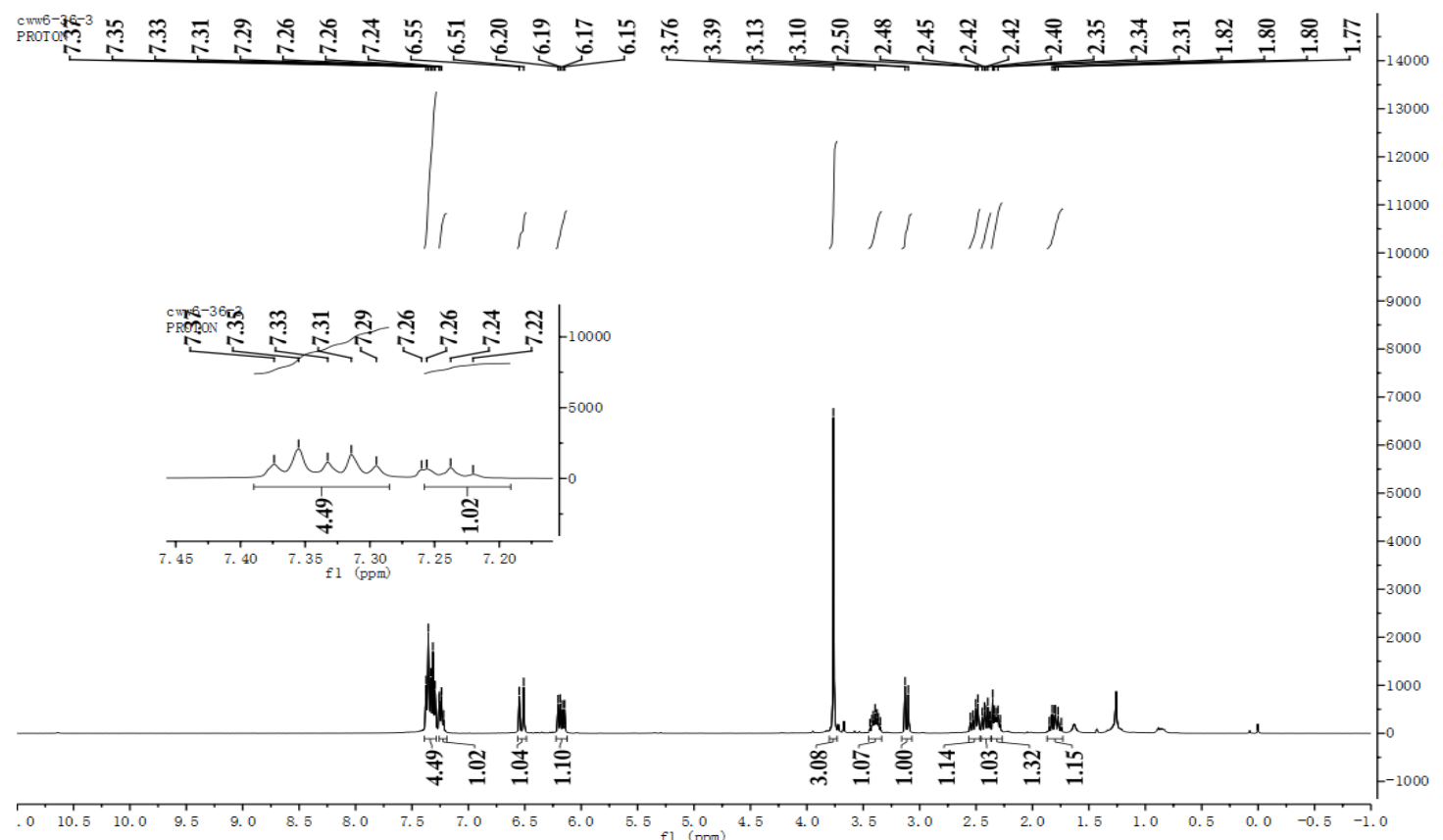

${ }^{13} \mathbf{C}$ NMR (100 MHz, $\left.\mathrm{CDCl}_{3}\right)$

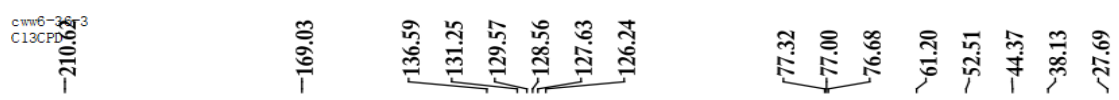

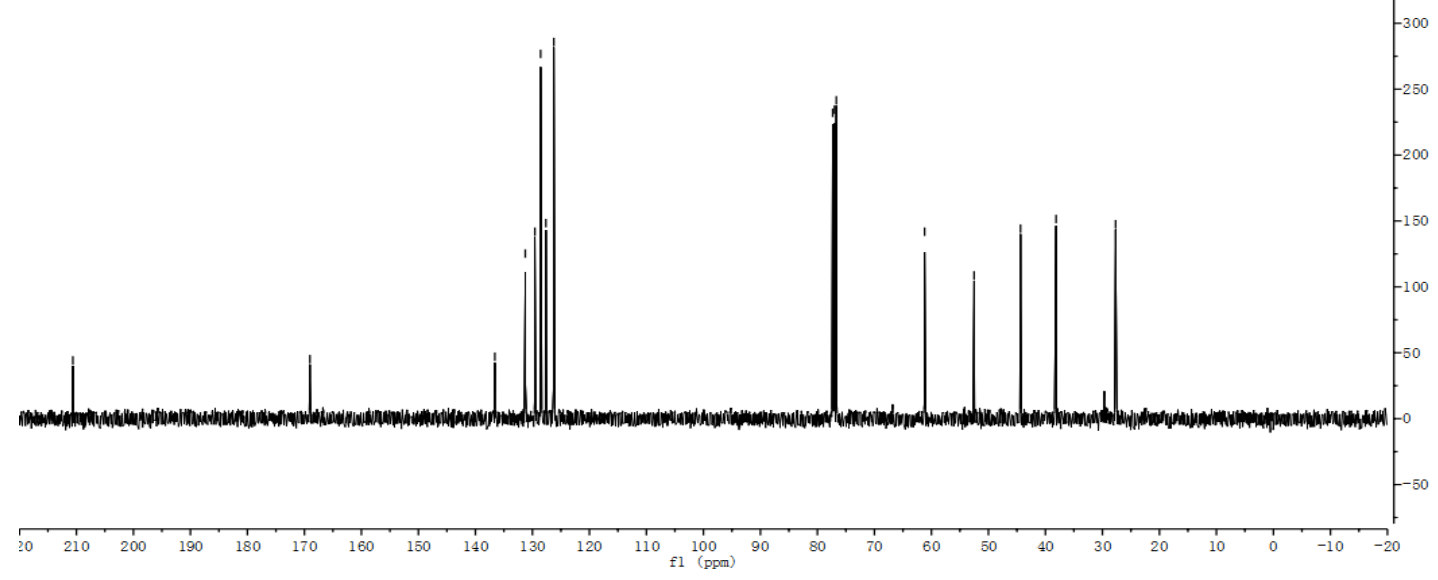




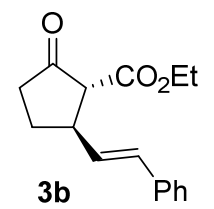

${ }^{1} \mathbf{H}$ NMR $\left(400 \mathrm{MHz}, \mathrm{CDCl}_{3}\right)$

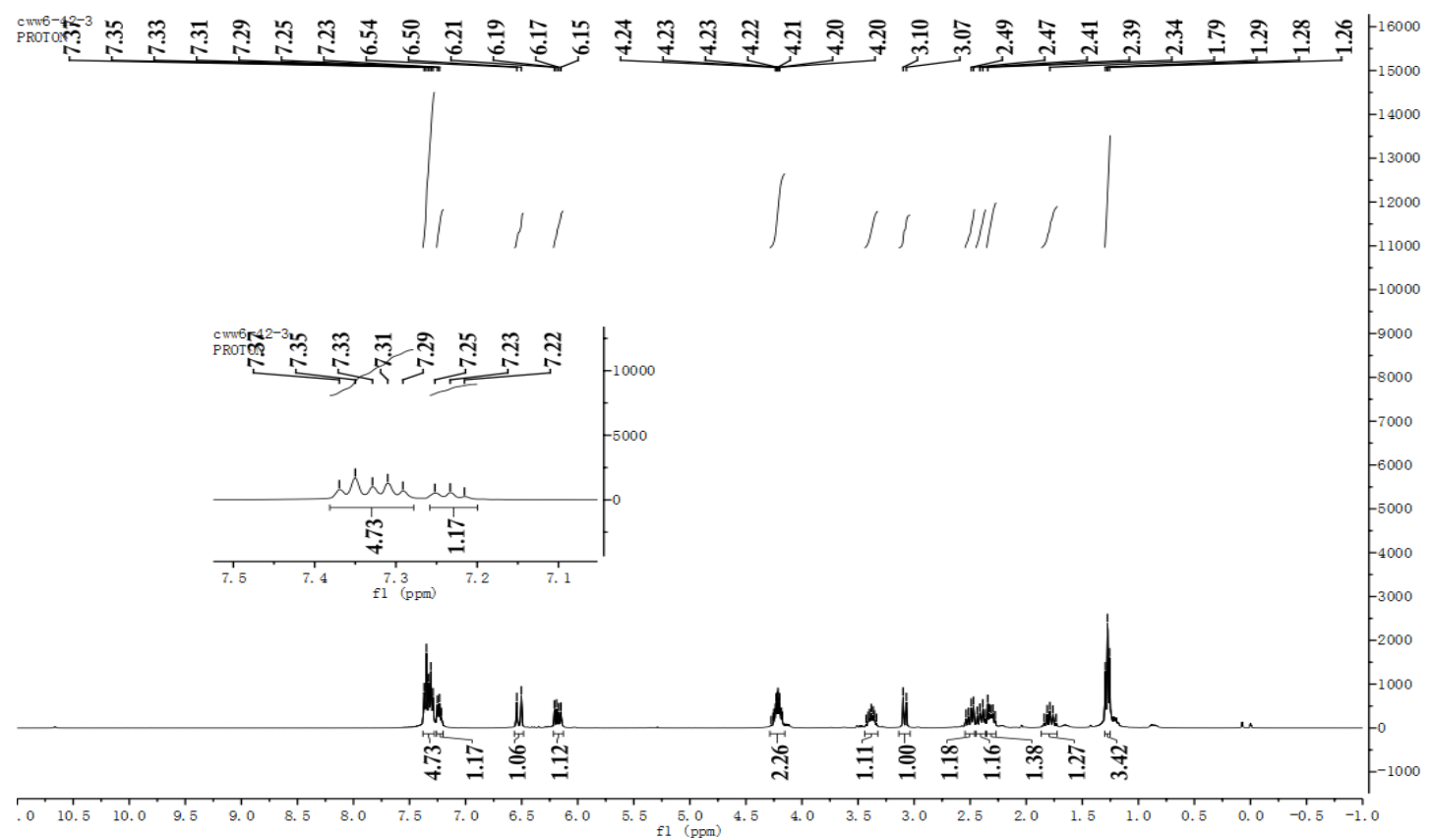

${ }^{13}$ C NMR (100 MHz, $\left.\mathrm{CDCl}_{3}\right)$

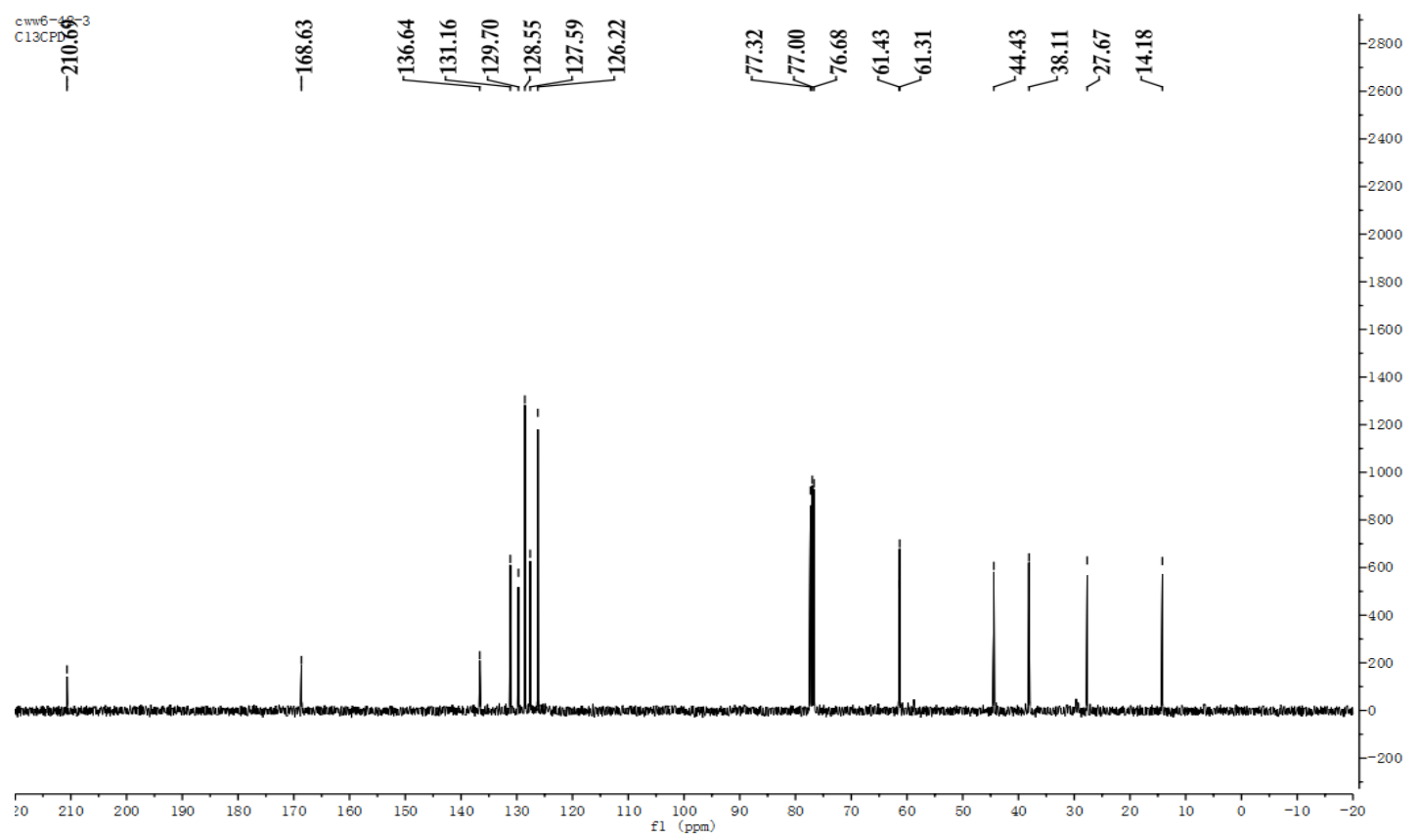




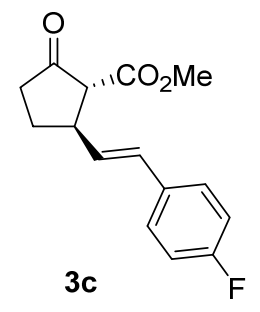

${ }^{1} \mathbf{H}$ NMR $\left(400 \mathrm{MHz}, \mathrm{CDCl}_{3}\right)$

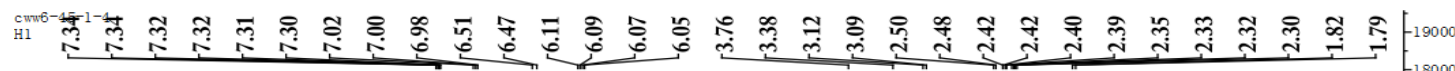
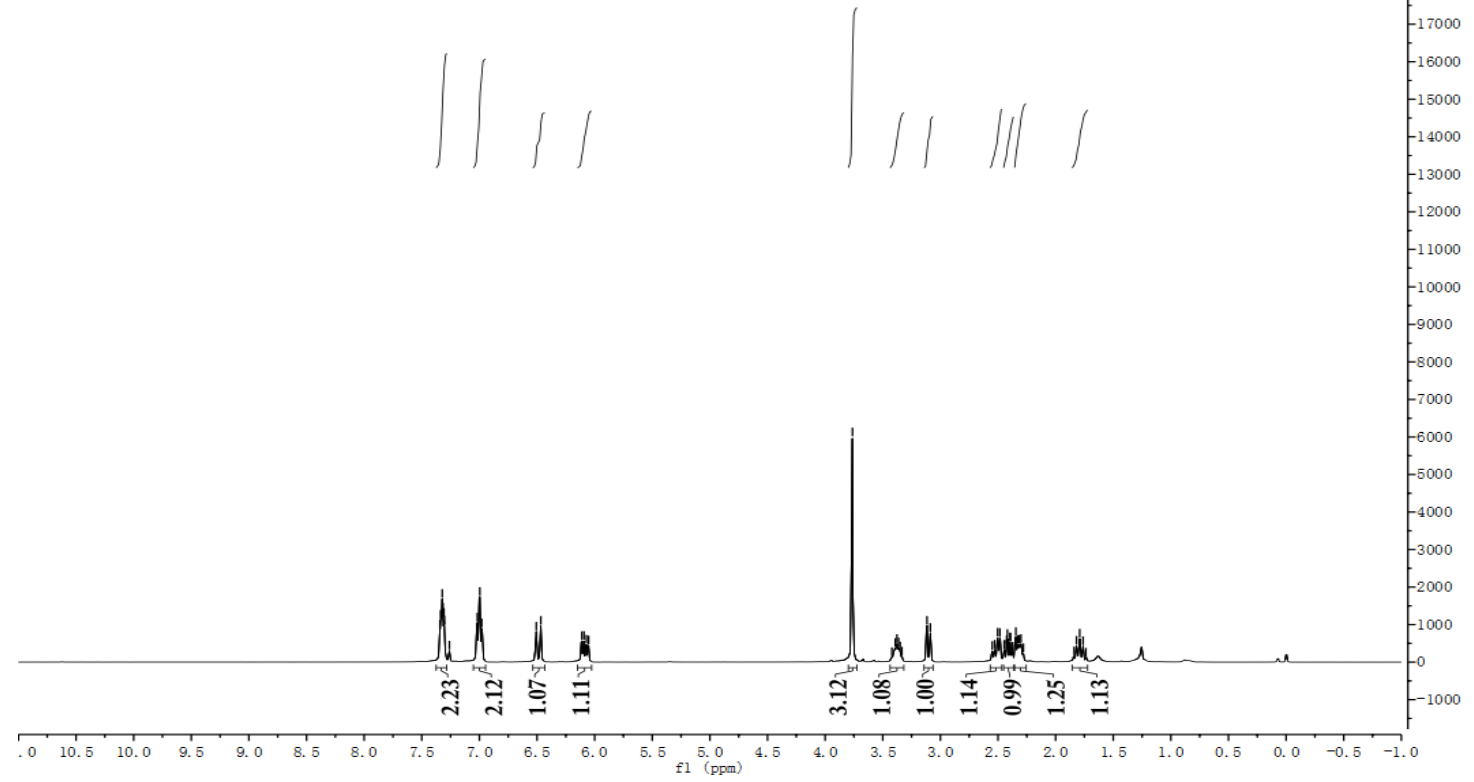

${ }^{13} \mathbf{C}$ NMR $\left(100 \mathrm{MHz}, \mathrm{CDCl}_{3}\right)$

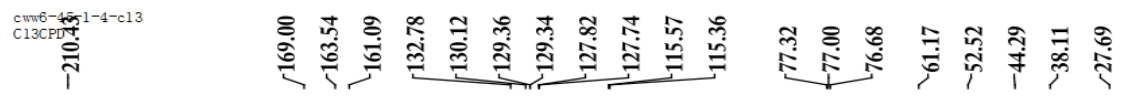

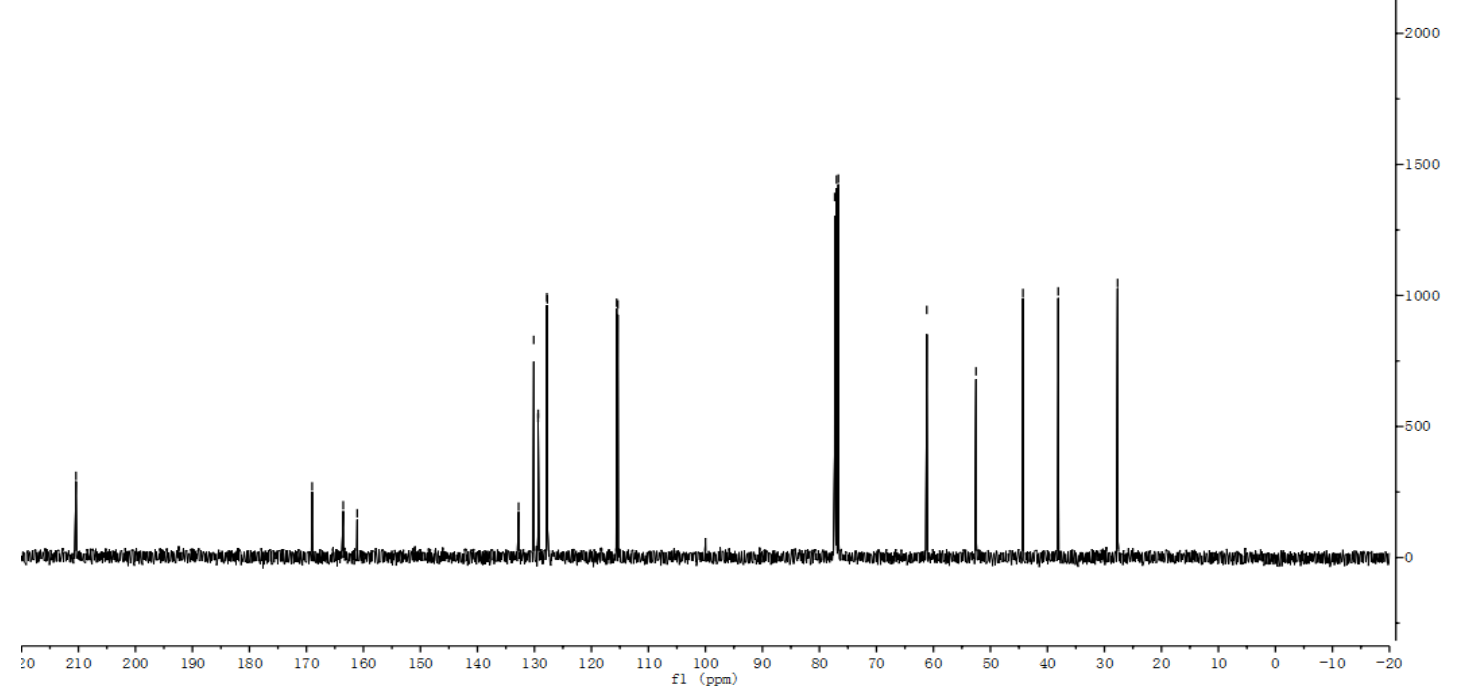


${ }^{19}$ F NMR (376 MHz, $\left.\mathrm{CDCl}_{3}\right)$

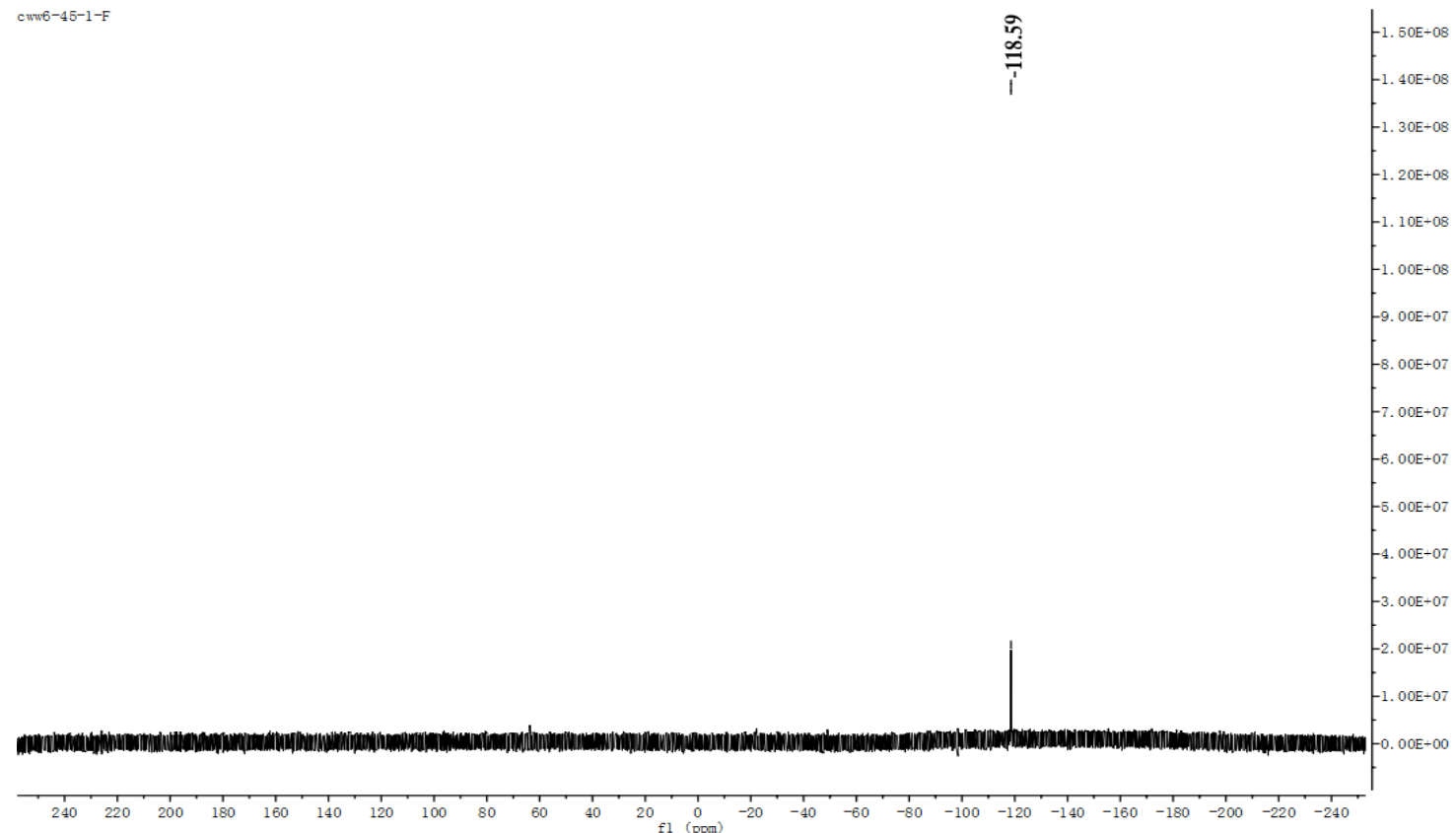




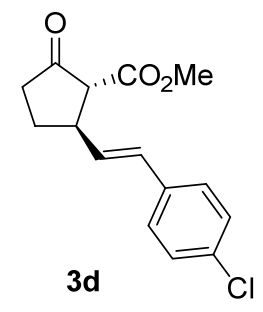

${ }^{1} \mathbf{H}$ NMR $\left(400 \mathrm{MHz}, \mathrm{CDCl}_{3}\right)$

PRorỡ
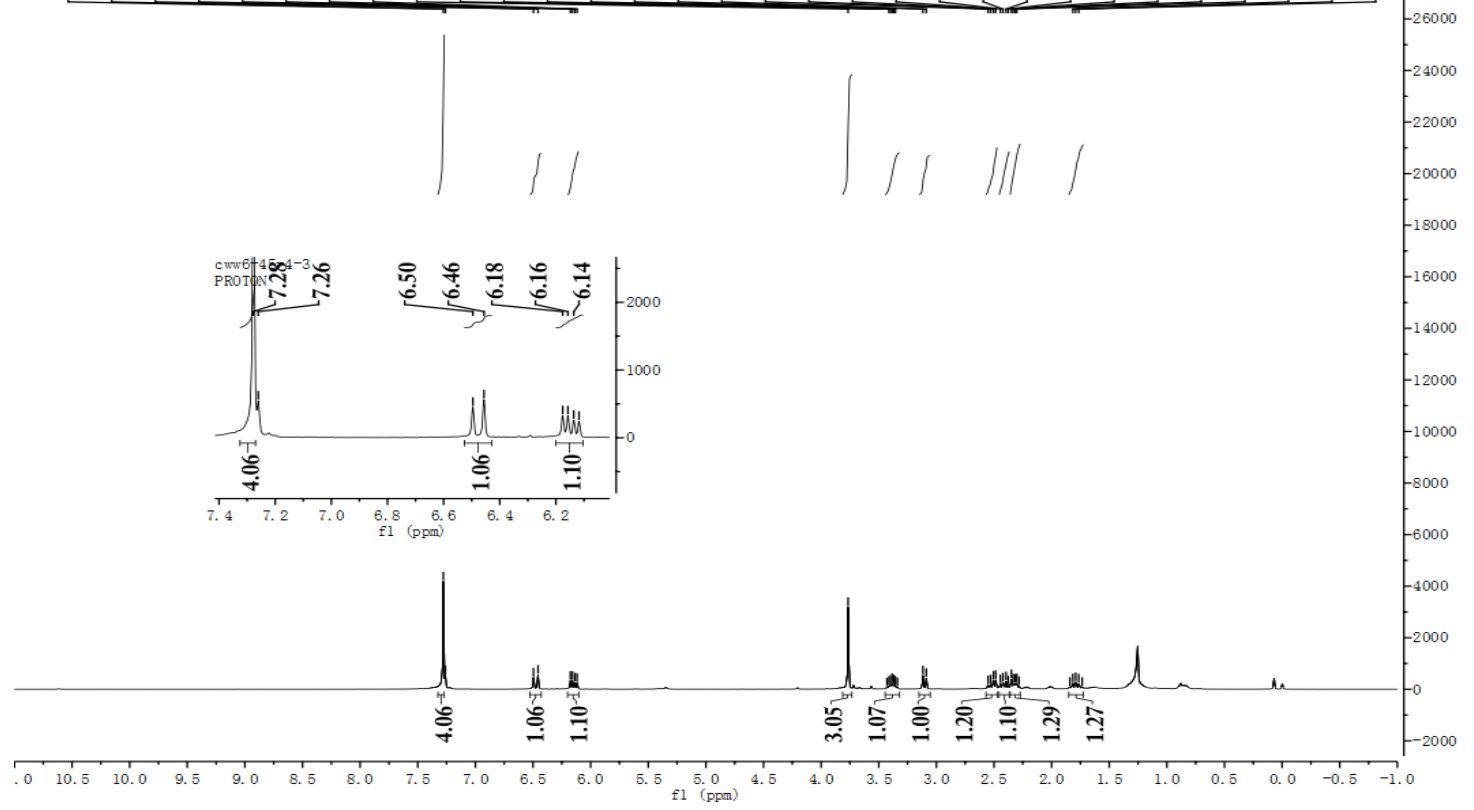

${ }^{13} \mathbf{C ~ N M R}\left(100 \mathrm{MHz}, \mathrm{CDCl}_{3}\right)$

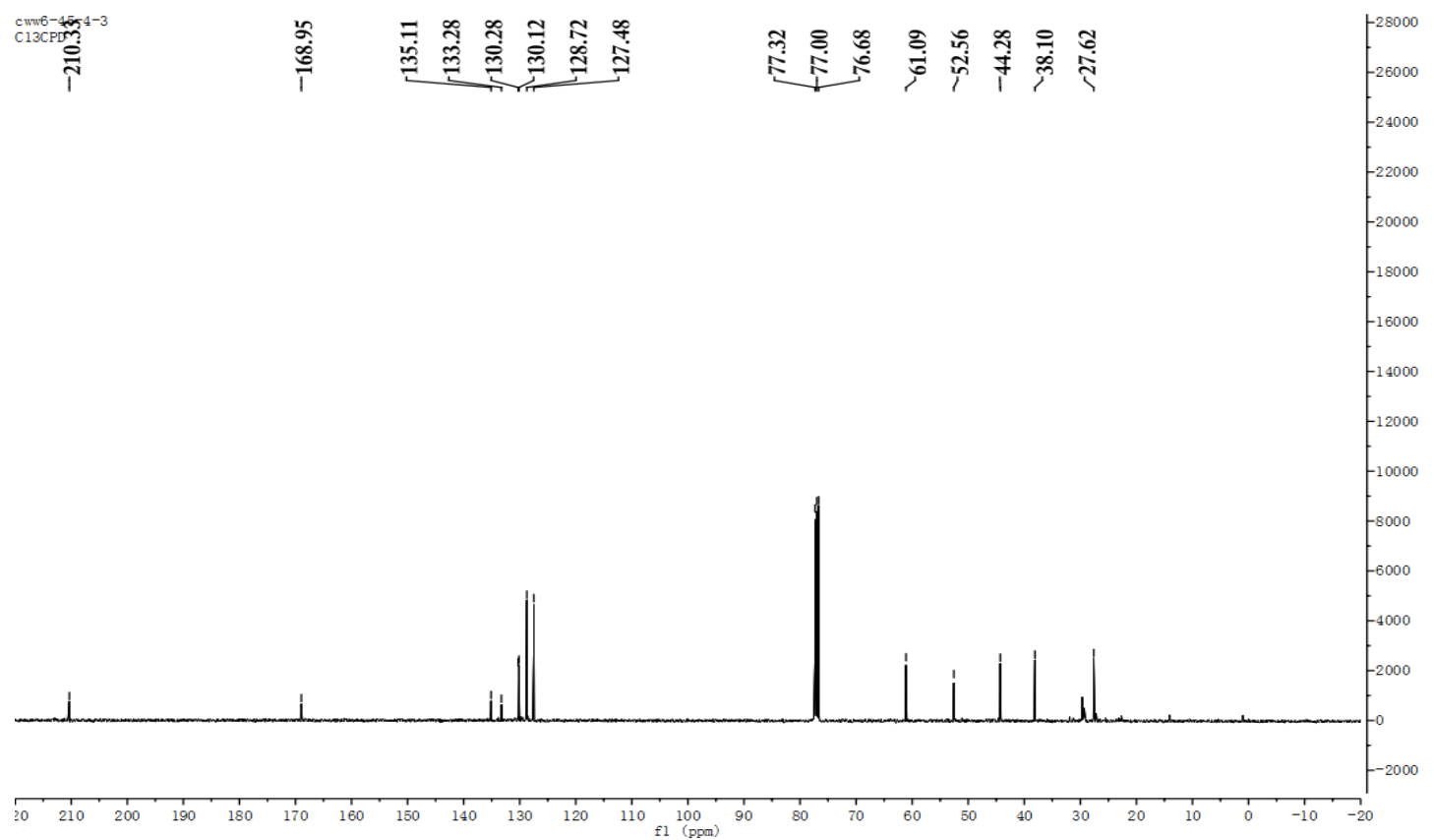




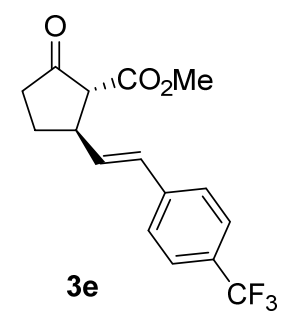

${ }^{1} \mathbf{H}$ NMR (400 MHz, $\left.\mathrm{CDCl}_{3}\right)$

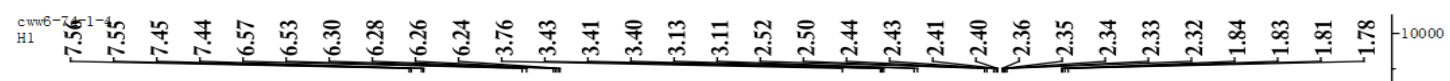
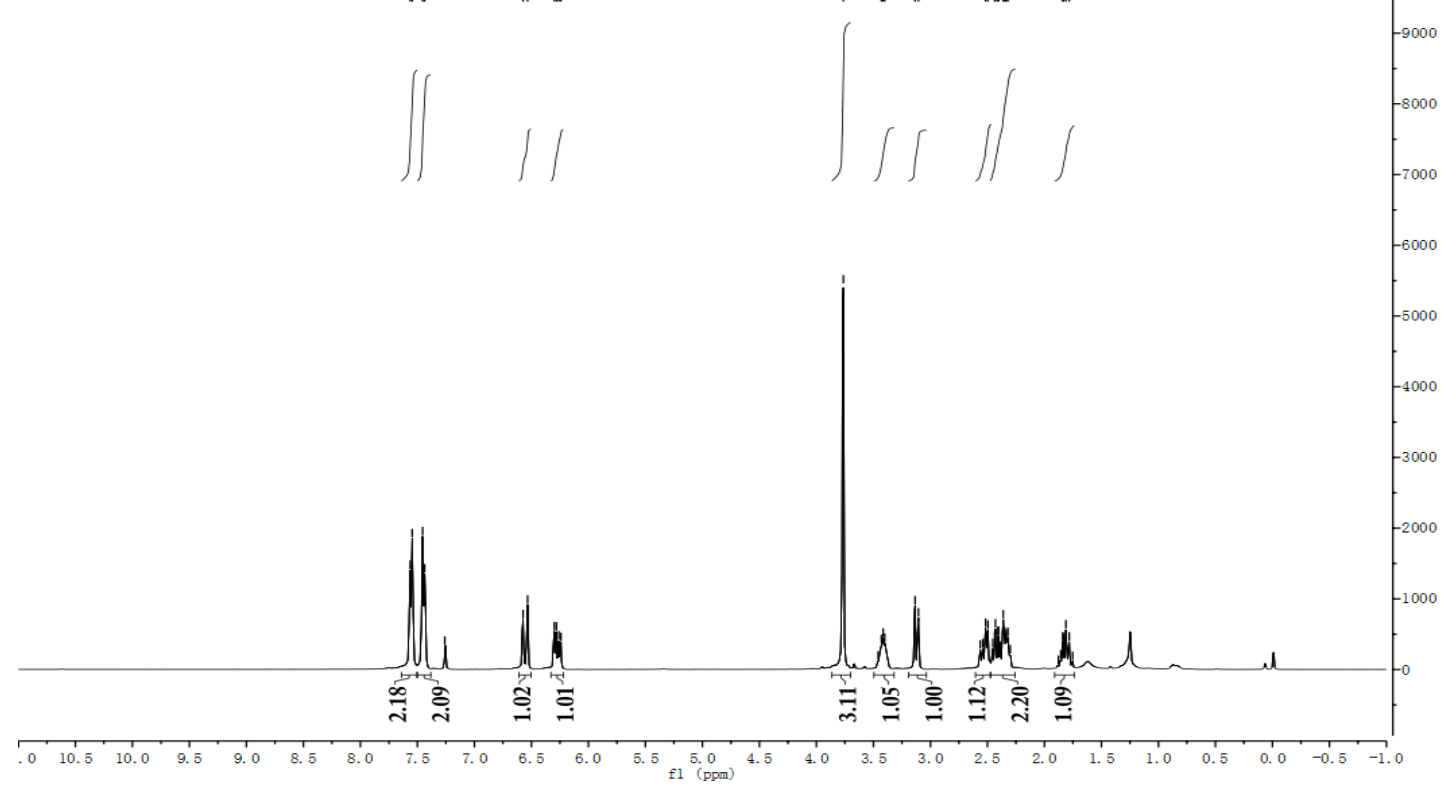

${ }^{13} \mathbf{C}$ NMR $\left(100 \mathrm{MHz}, \mathrm{CDCl}_{3}\right)$

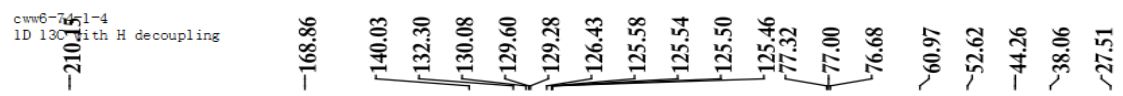

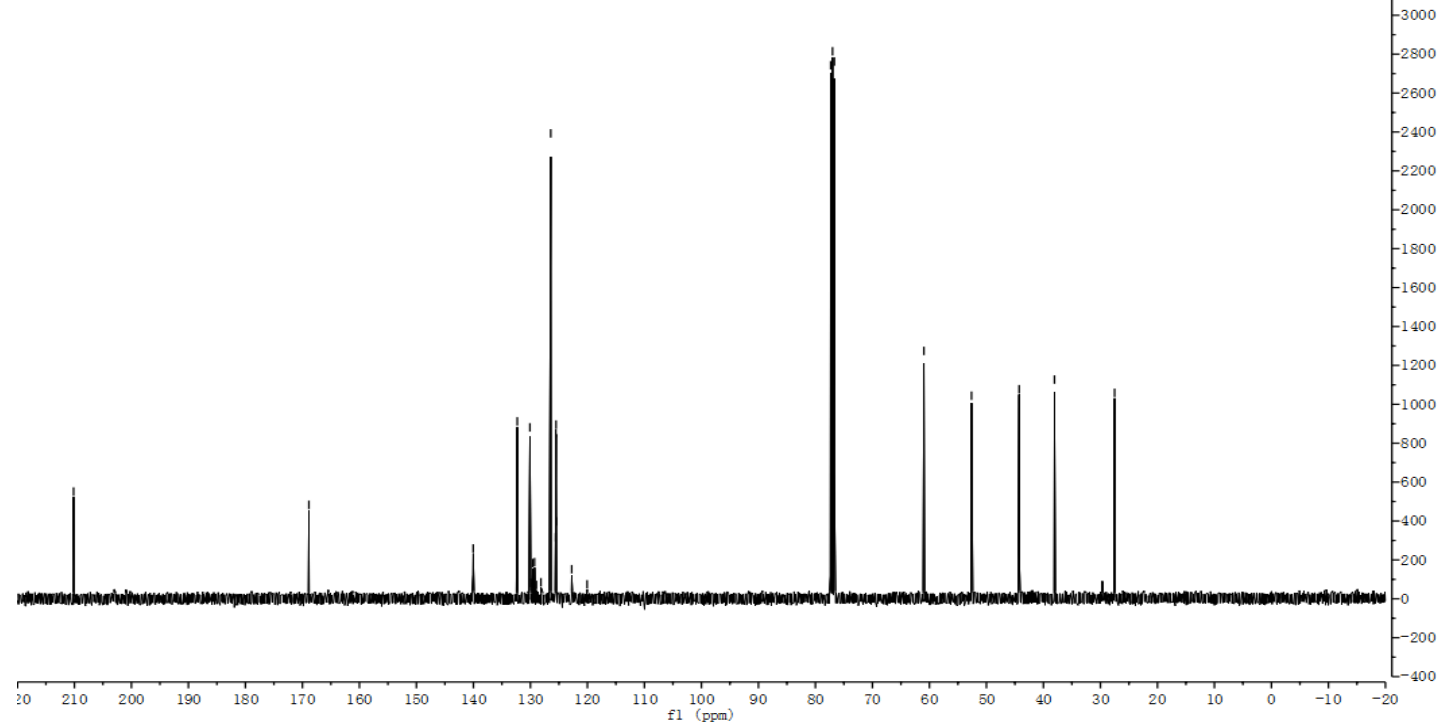


${ }^{19} \mathbf{F}$ NMR $\left(376 \mathrm{MHz}, \mathrm{CDCl}_{3}\right)$

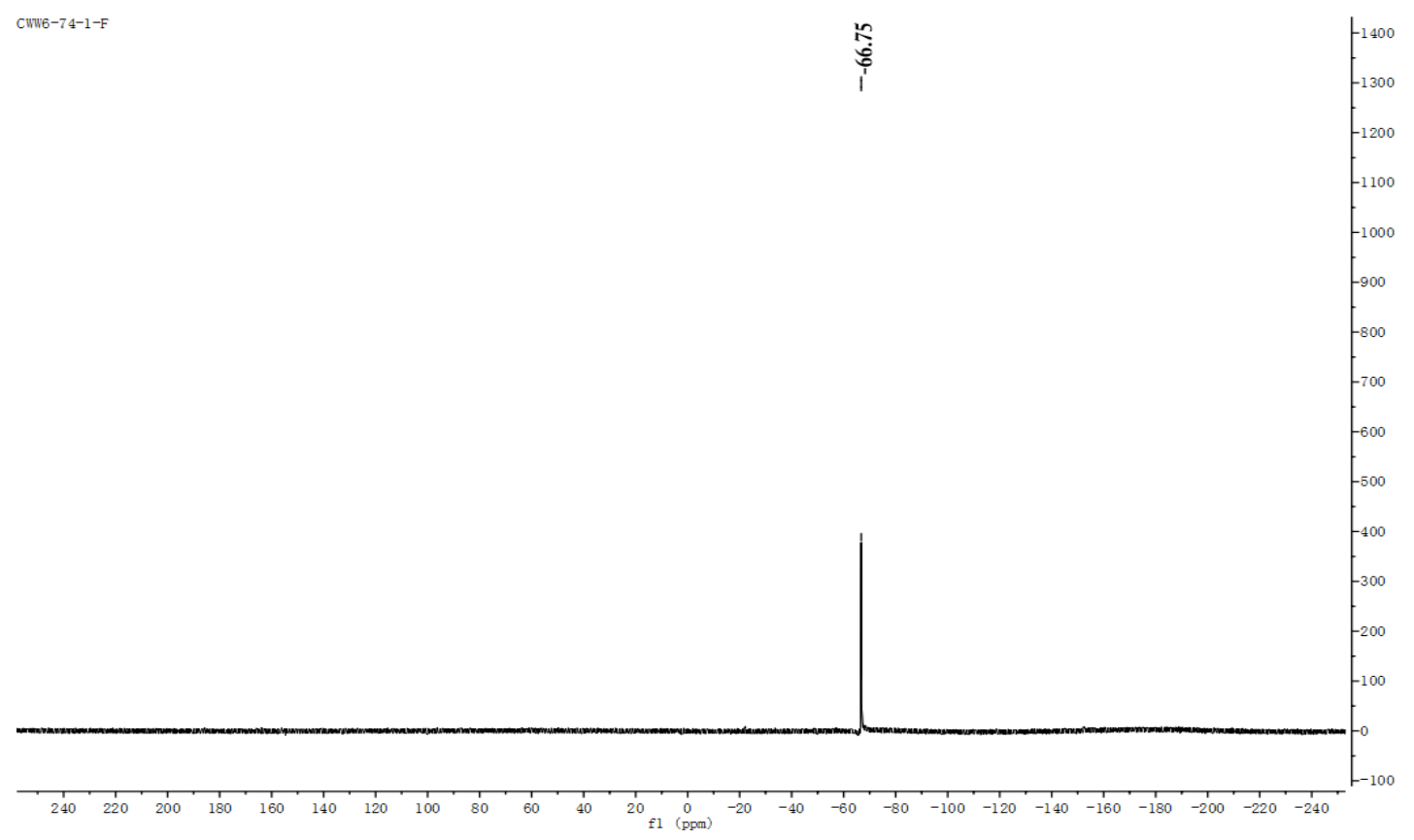




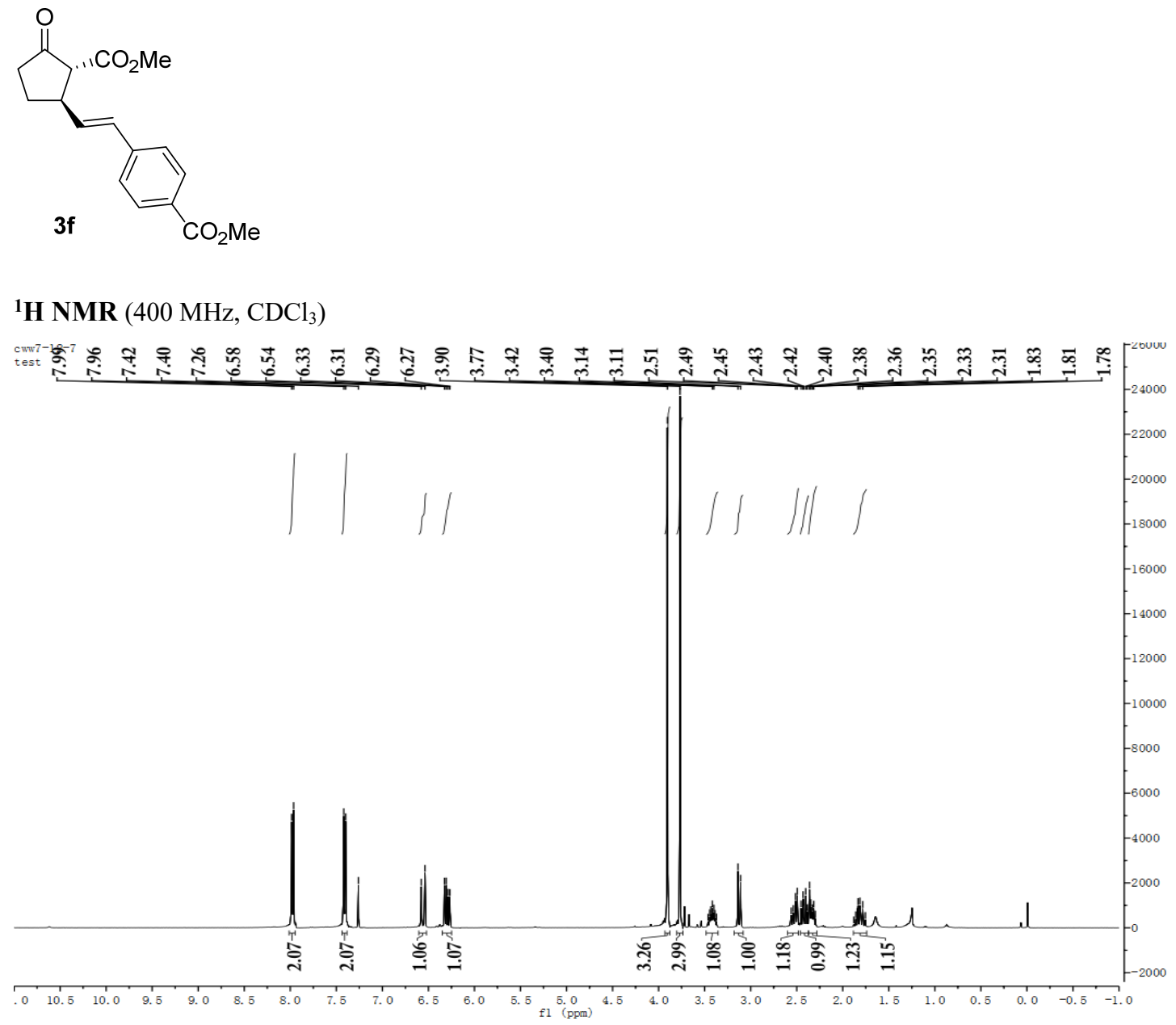

${ }^{13}$ C NMR (100 MHz, $\left.\mathrm{CDCl}_{3}\right)$

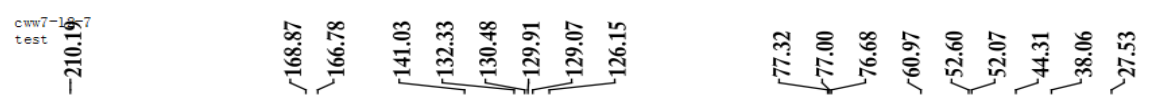

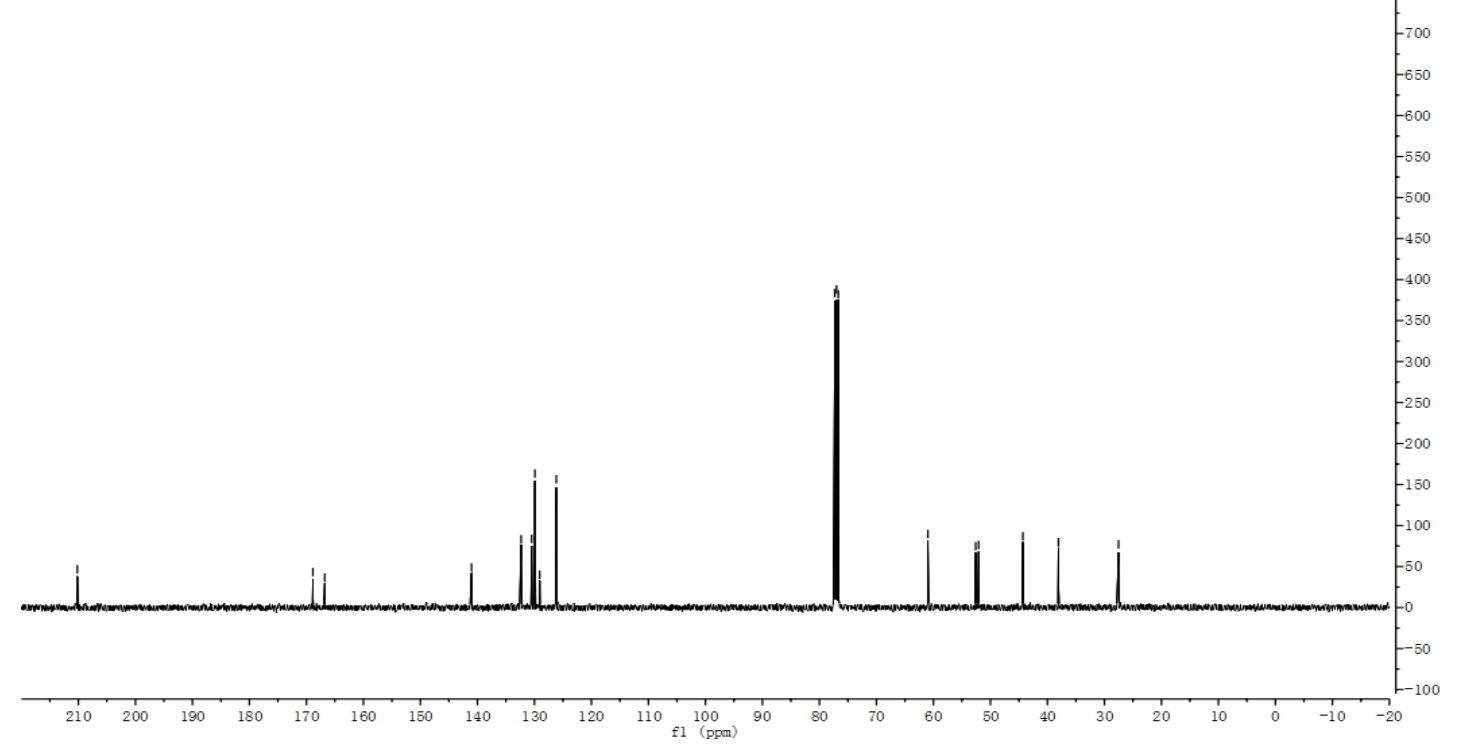




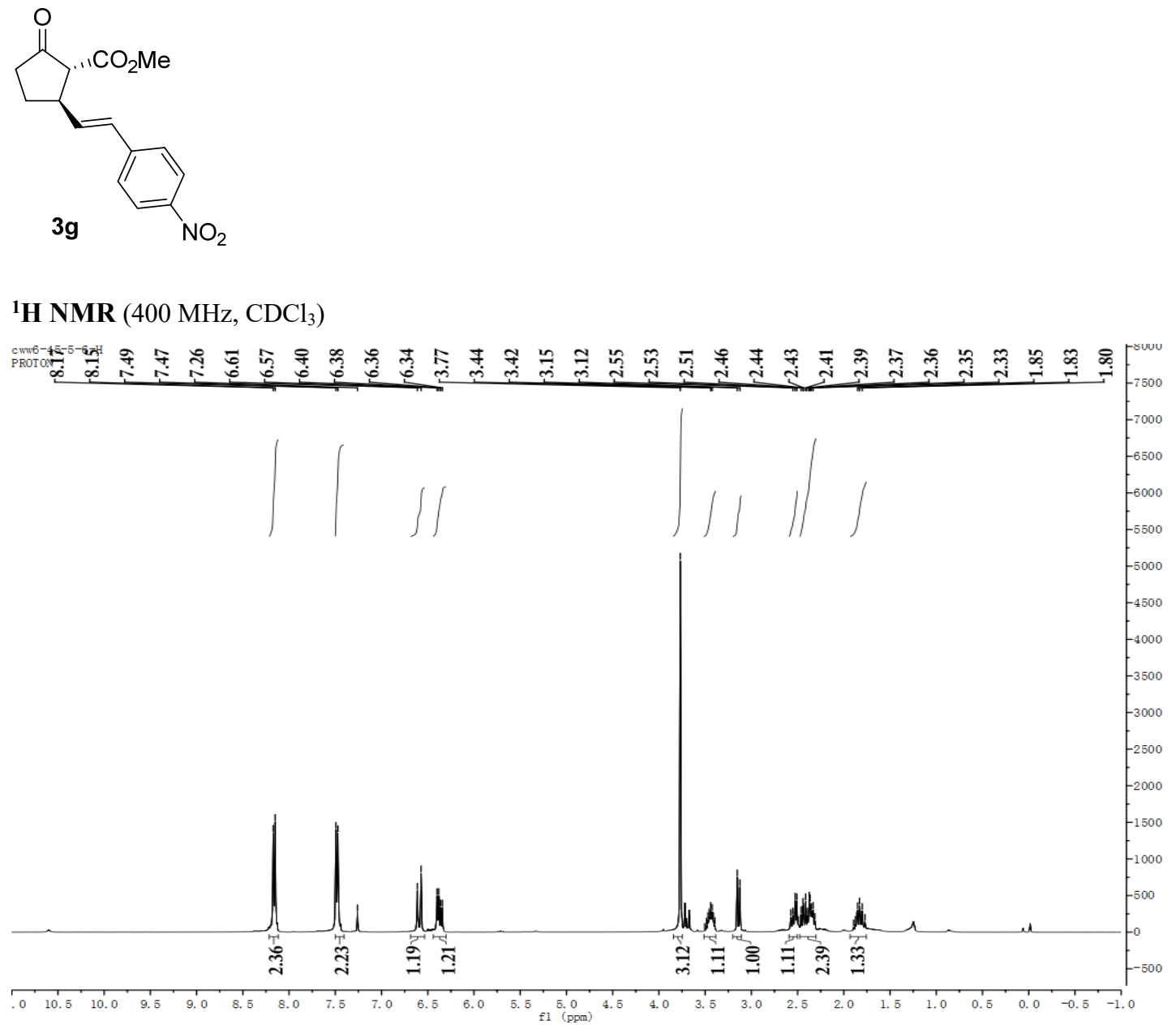

${ }^{13}$ C NMR (100 MHz, $\left.\mathrm{CDCl}_{3}\right)$

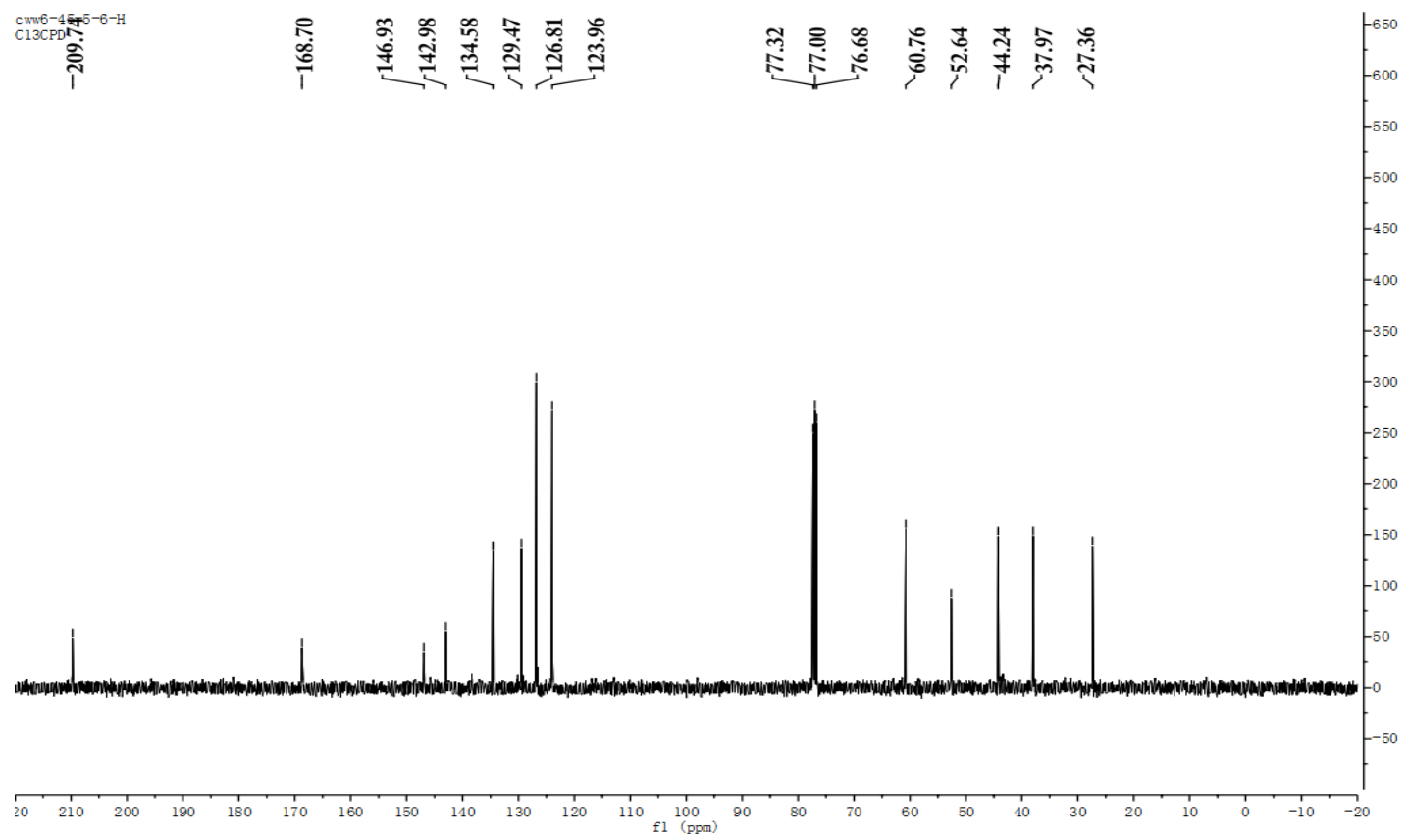




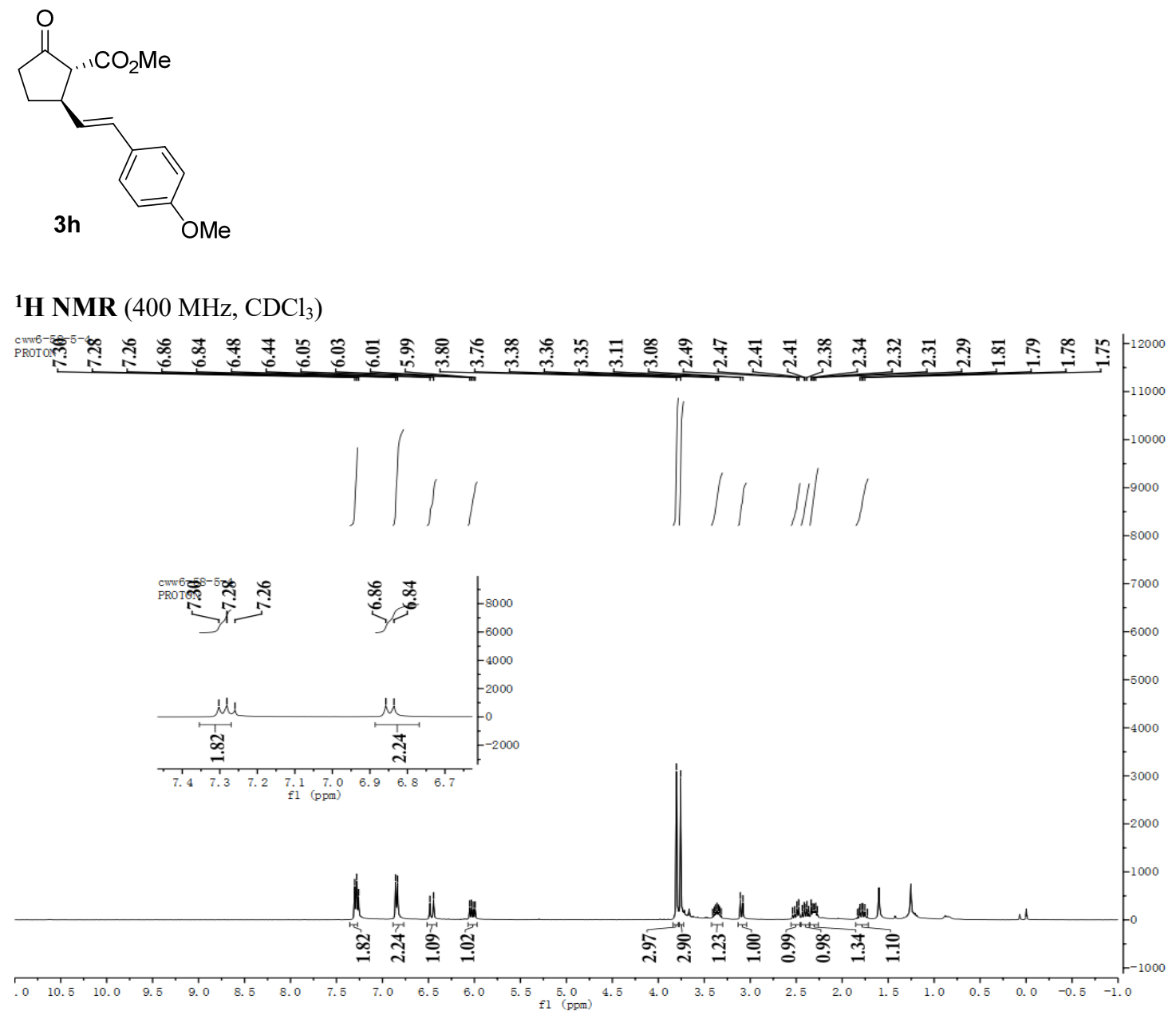

${ }^{13}$ C NMR (100 MHz, $\left.\mathrm{CDCl}_{3}\right)$

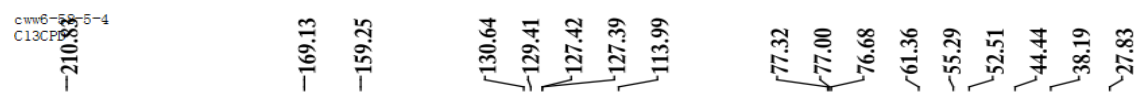

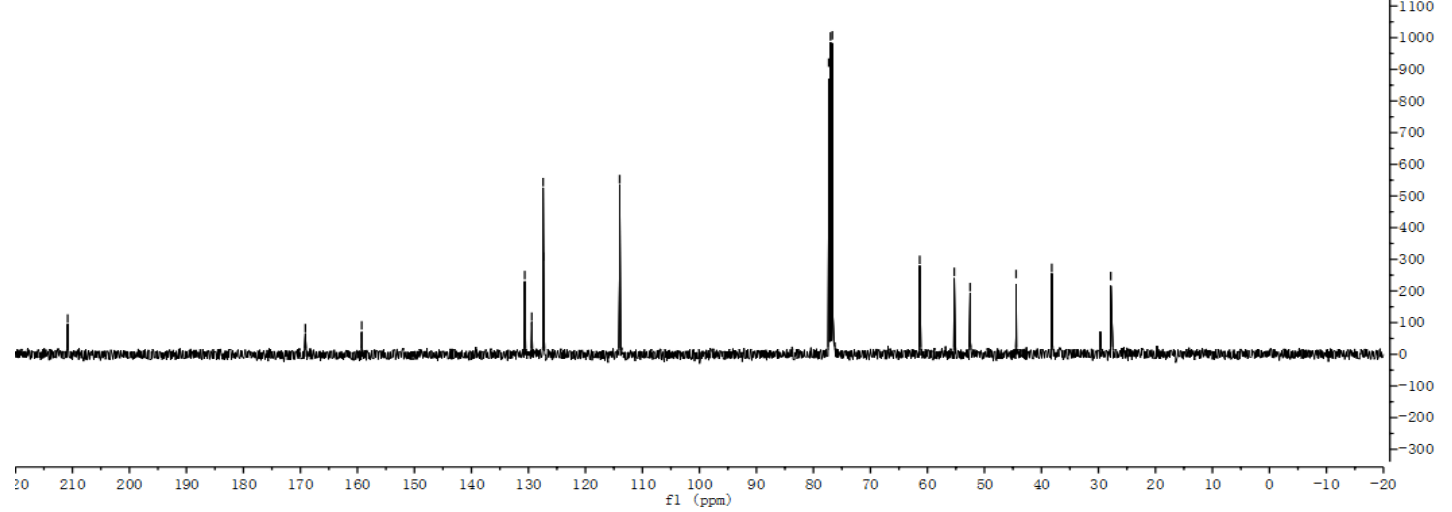




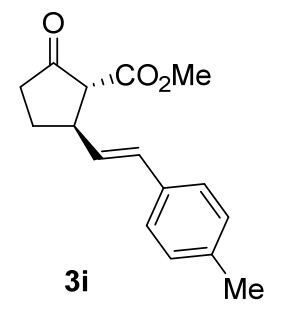

${ }^{1} \mathbf{H}$ NMR (400 MHz, $\left.\mathrm{CDCl}_{3}\right)$

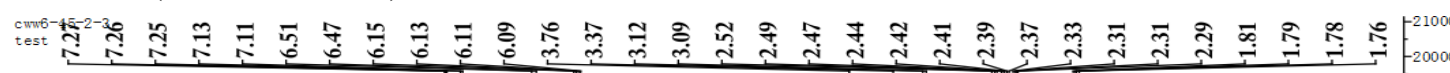
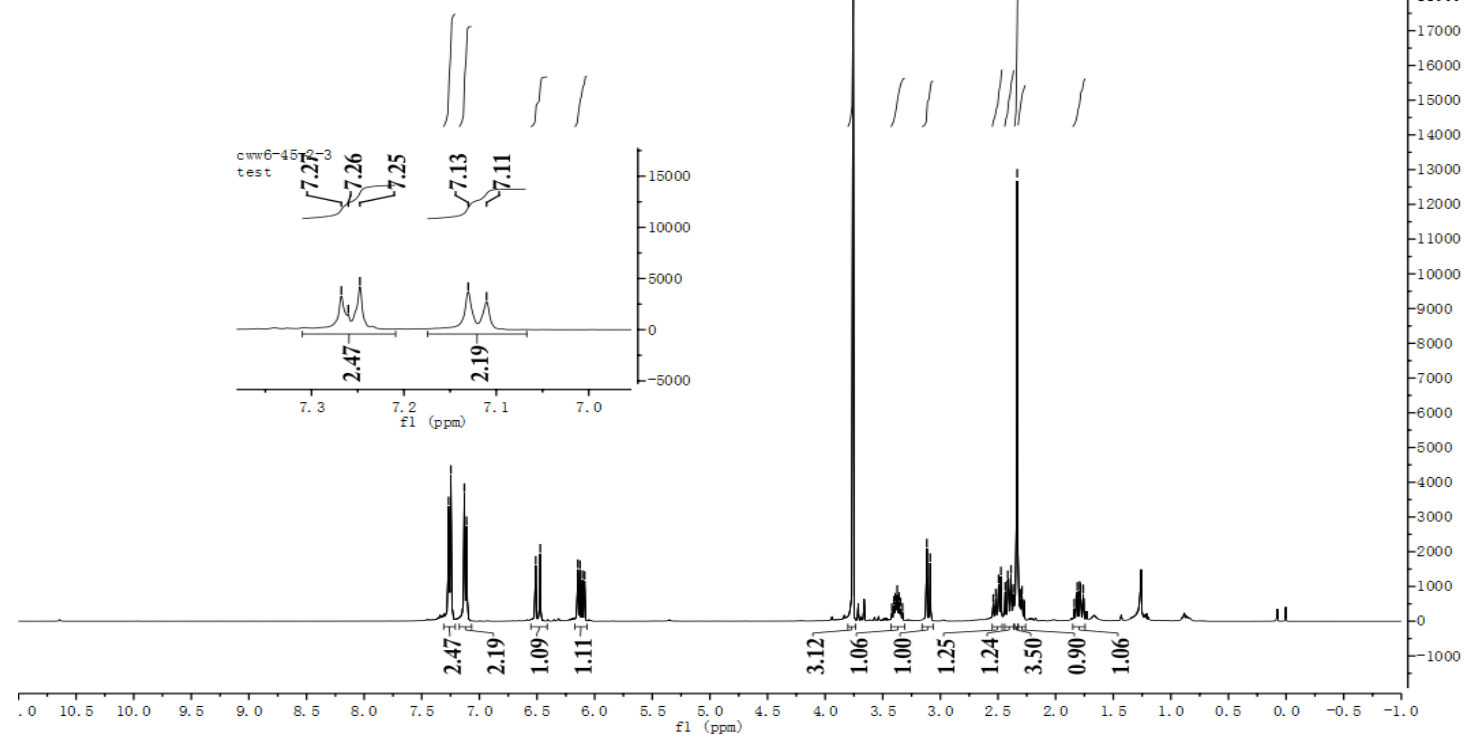

${ }^{13}$ C NMR (100 MHz, $\left.\mathrm{CDCl}_{3}\right)$

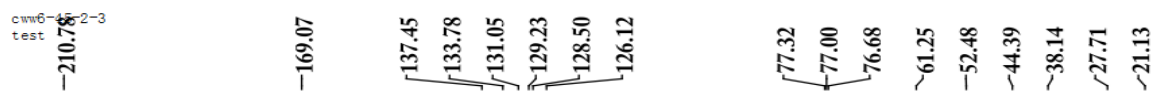

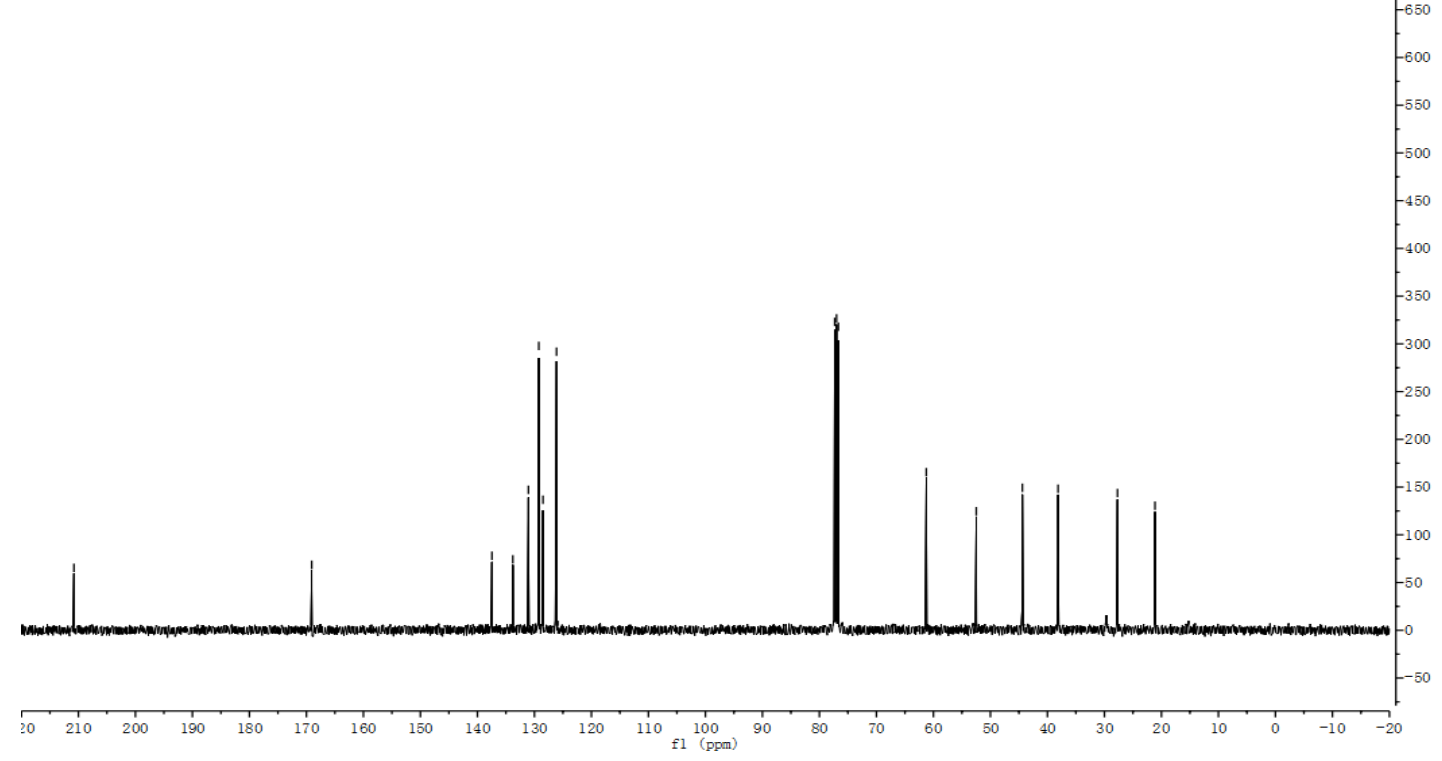




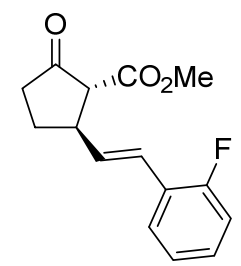

3j

${ }^{1} \mathbf{H}$ NMR $\left(400 \mathrm{MHz}, \mathrm{CDCl}_{3}\right)$

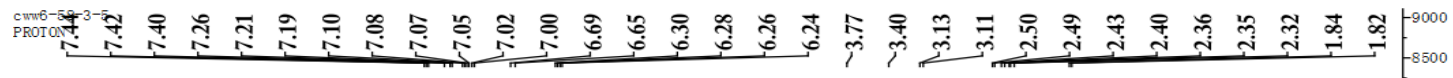

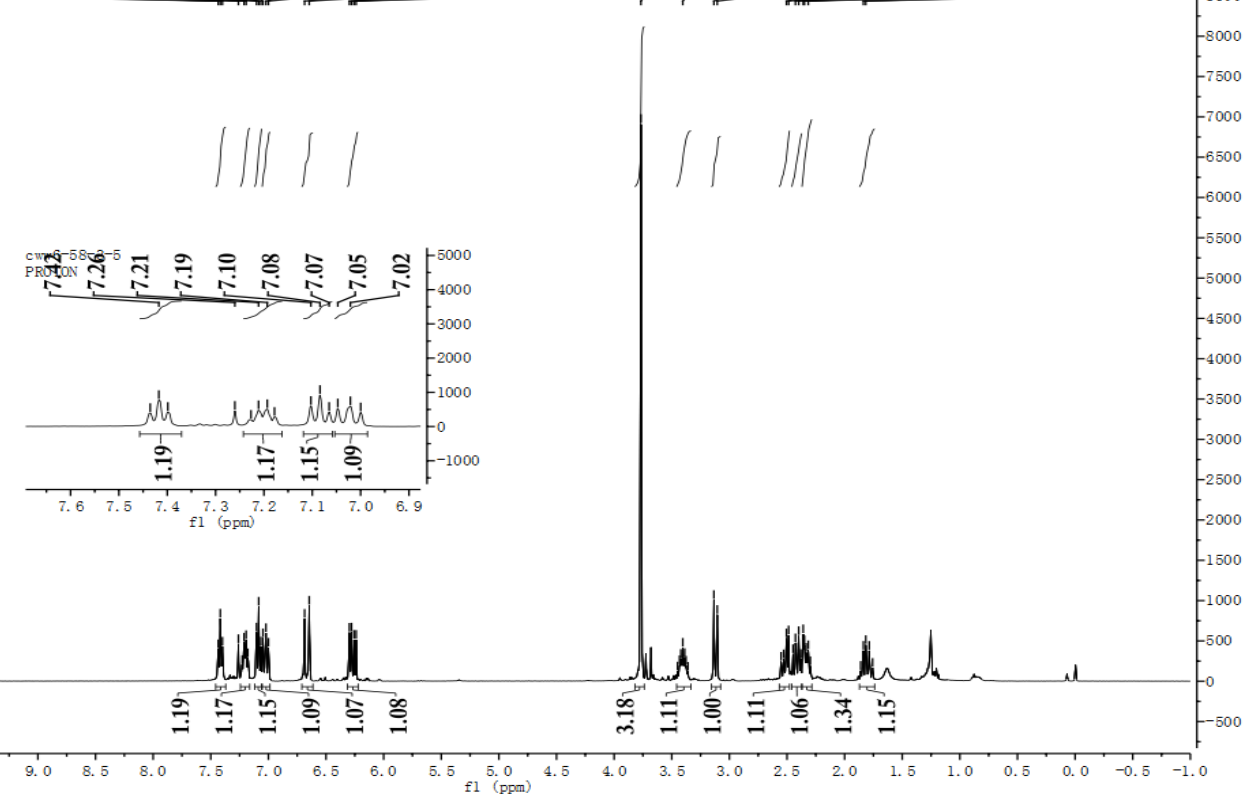

${ }^{13} \mathbf{C}$ NMR $\left(100 \mathrm{MHz}, \mathrm{CDCl}_{3}\right)$

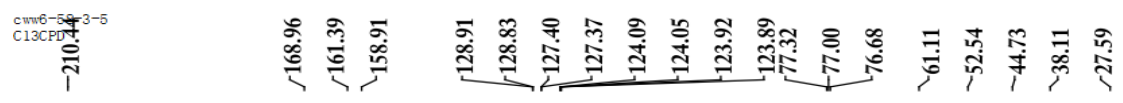

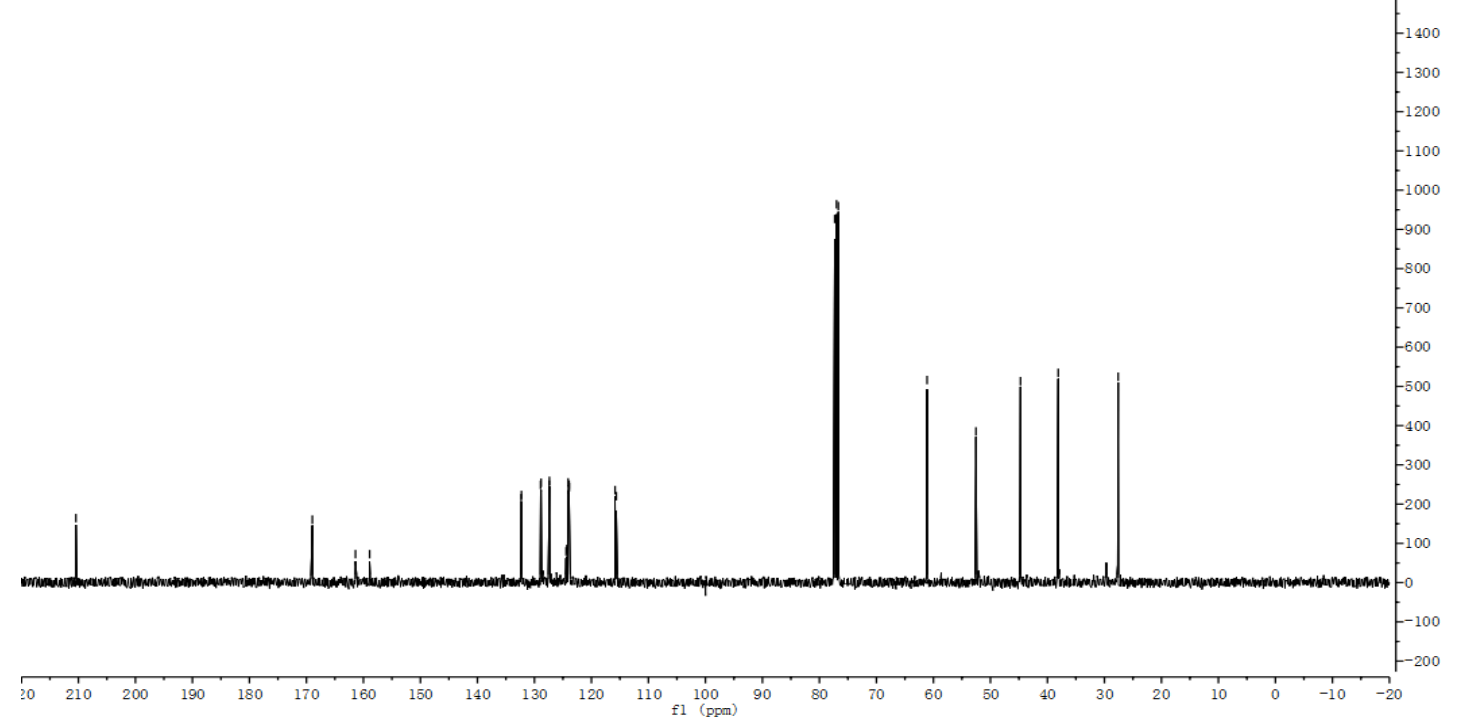


${ }^{19}$ F NMR (376 MHz, $\left.\mathrm{CDCl}_{3}\right)$

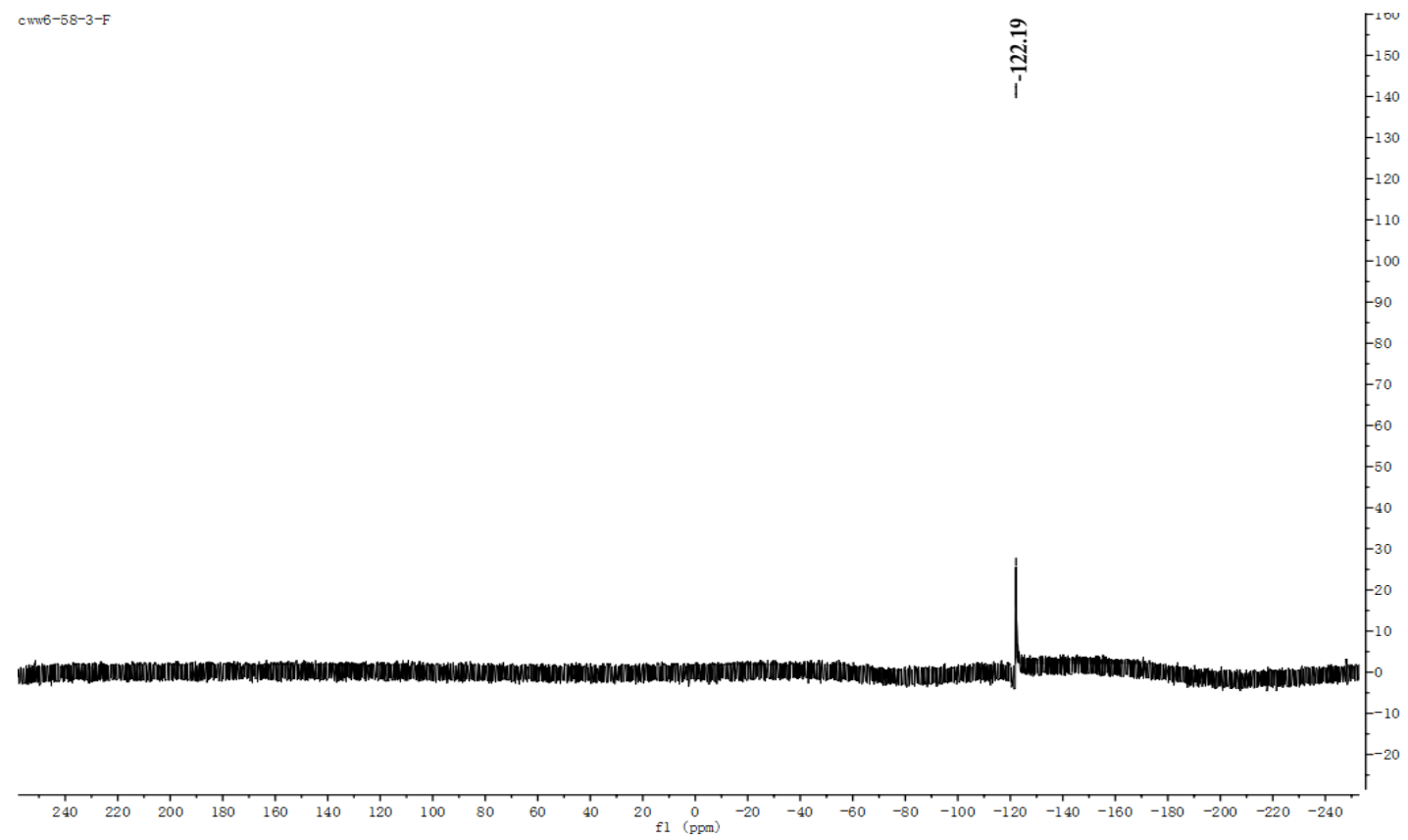




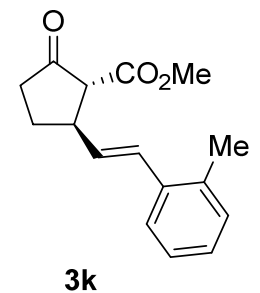

${ }^{1} \mathbf{H}$ NMR (400 MHz, $\left.\mathrm{CDCl}_{3}\right)$

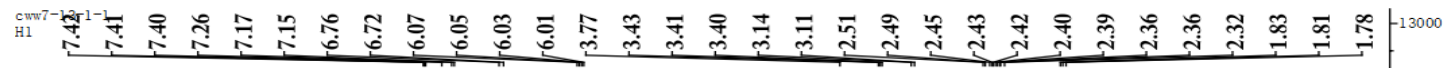

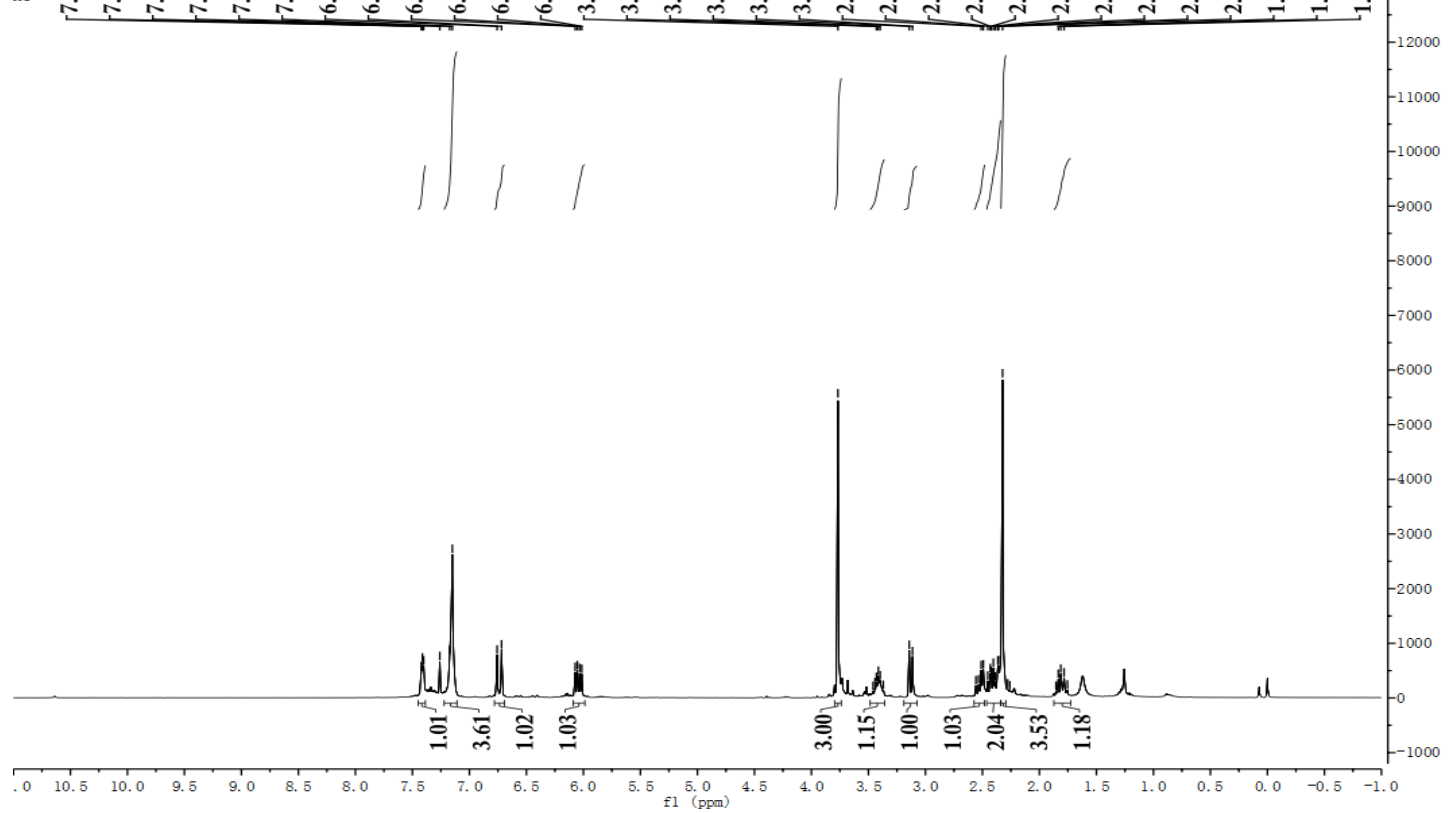

${ }^{13}$ C NMR (100 MHz, $\left.\mathrm{CDCl}_{3}\right)$

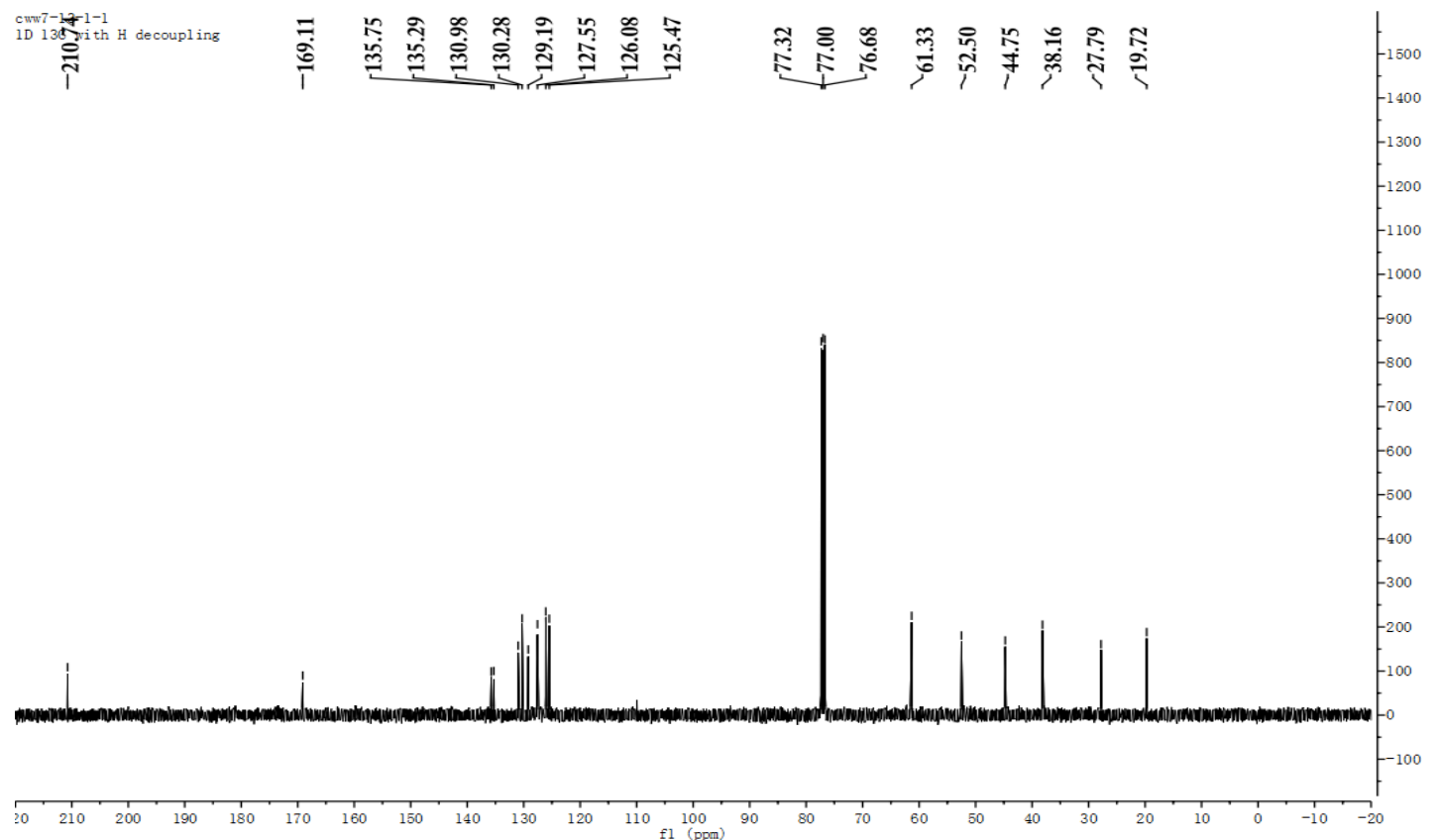




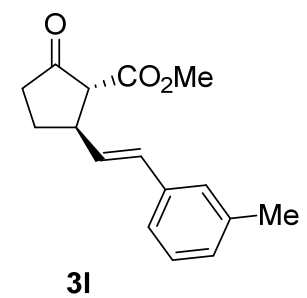

${ }^{1} \mathbf{H}$ NMR $\left(400 \mathrm{MHz}, \mathrm{CDCl}_{3}\right)$

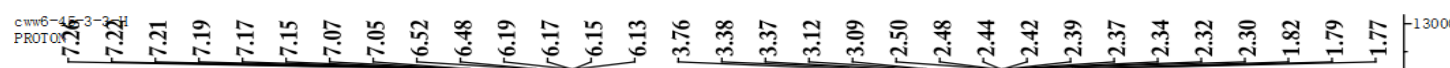
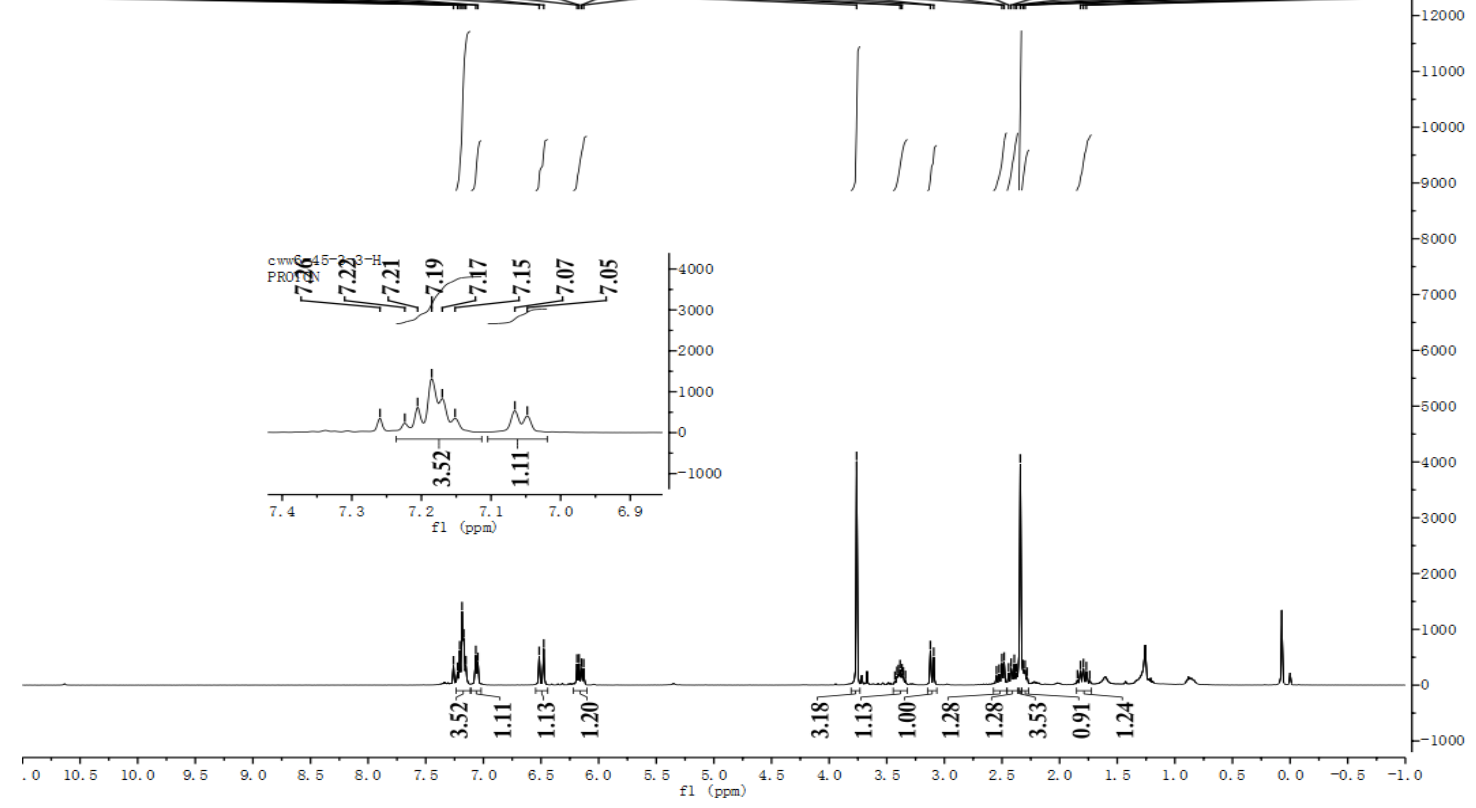

${ }^{13}$ C NMR (100 MHz, $\left.\mathrm{CDCl}_{3}\right)$

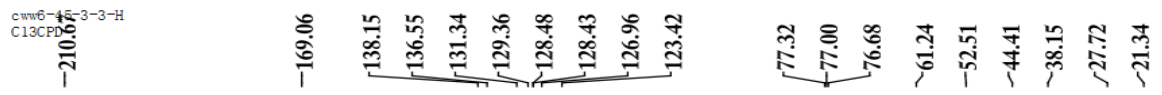

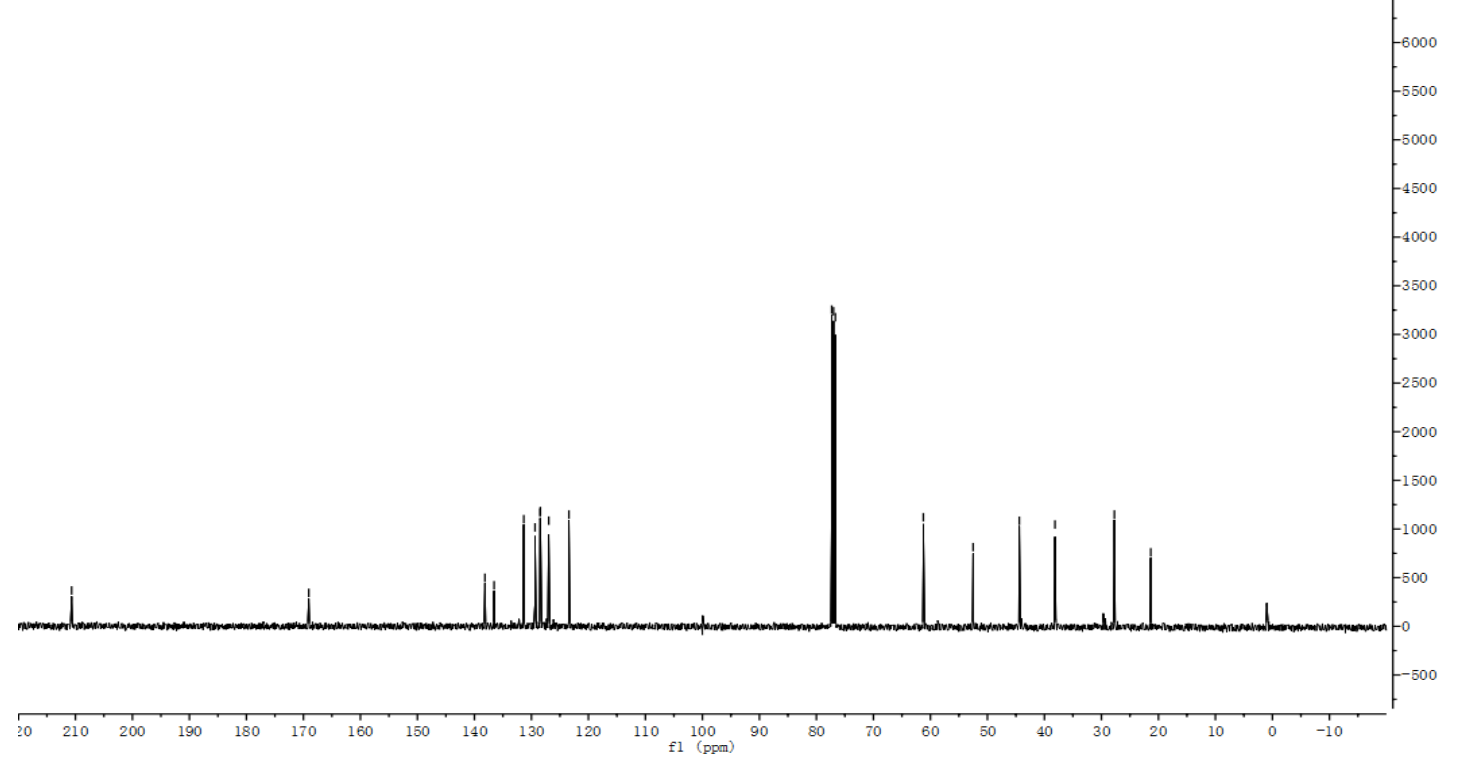




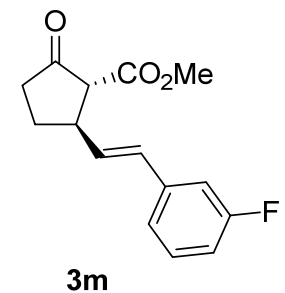

${ }^{1} \mathbf{H}$ NMR (400 MHz, $\left.\mathrm{CDCl}_{3}\right)$

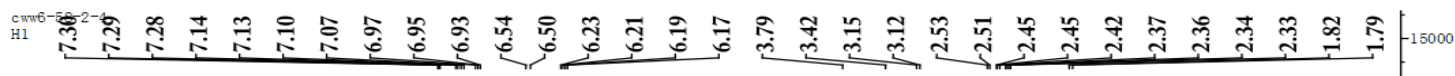

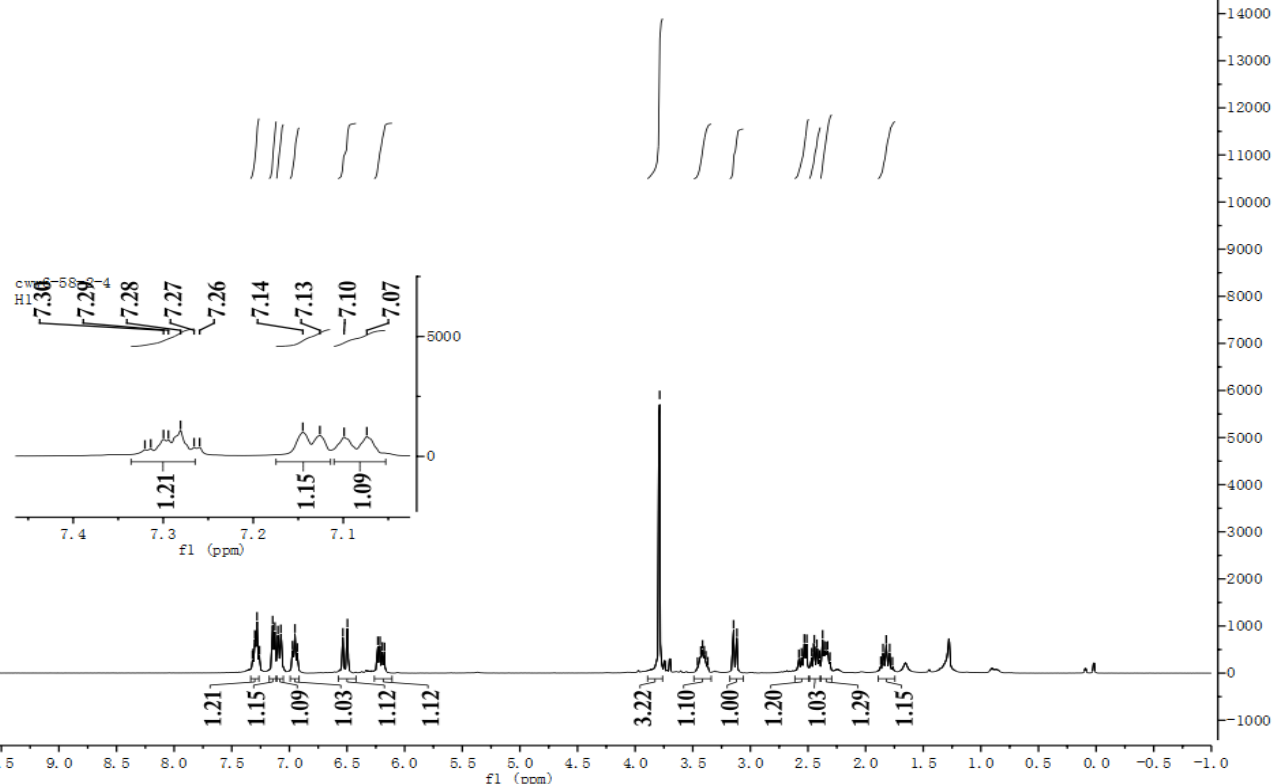

${ }^{13}$ C NMR $\left(100 \mathrm{MHz}, \mathrm{CDCl}_{3}\right)$

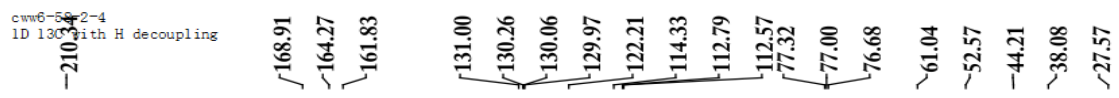

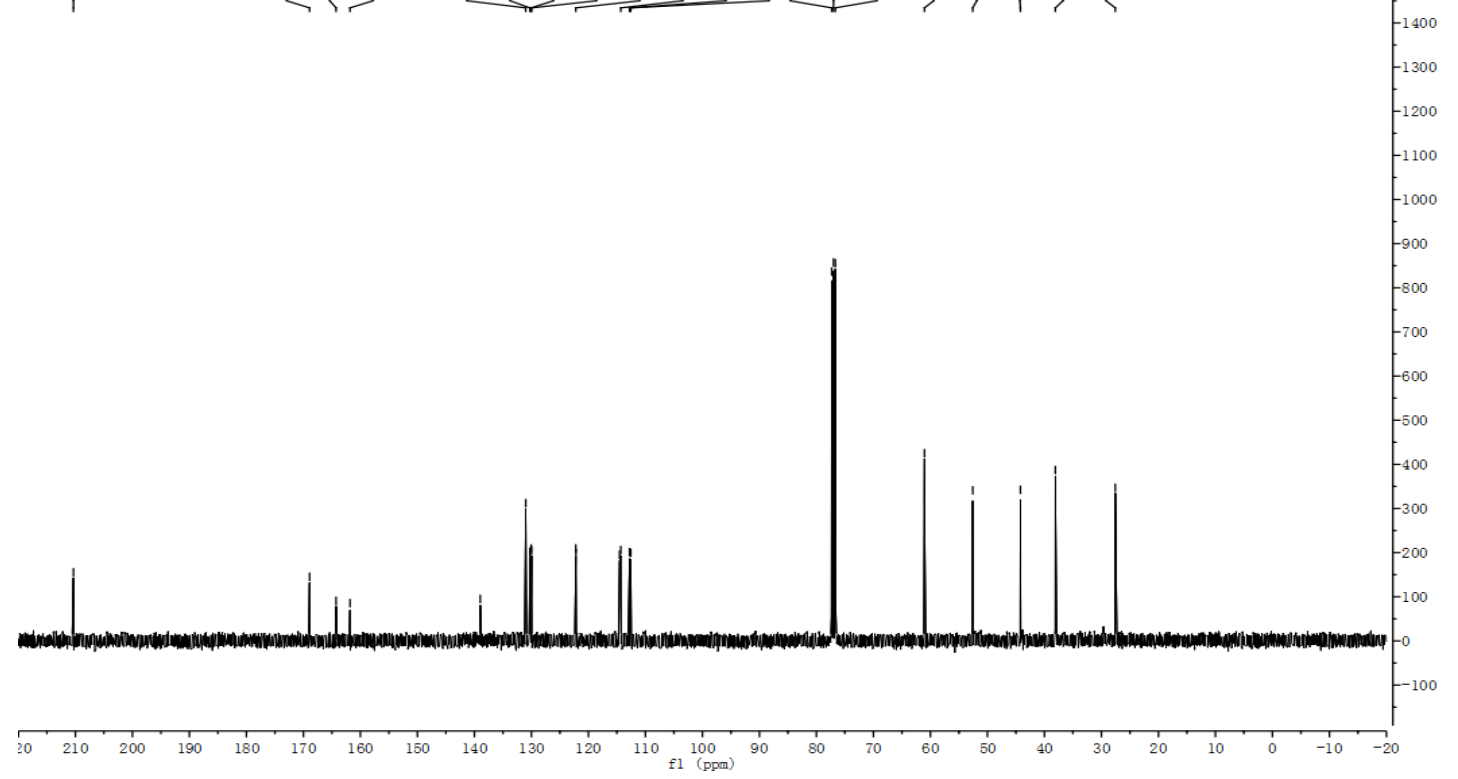


${ }^{19}$ F NMR (376 MHz, $\left.\mathrm{CDCl}_{3}\right)$

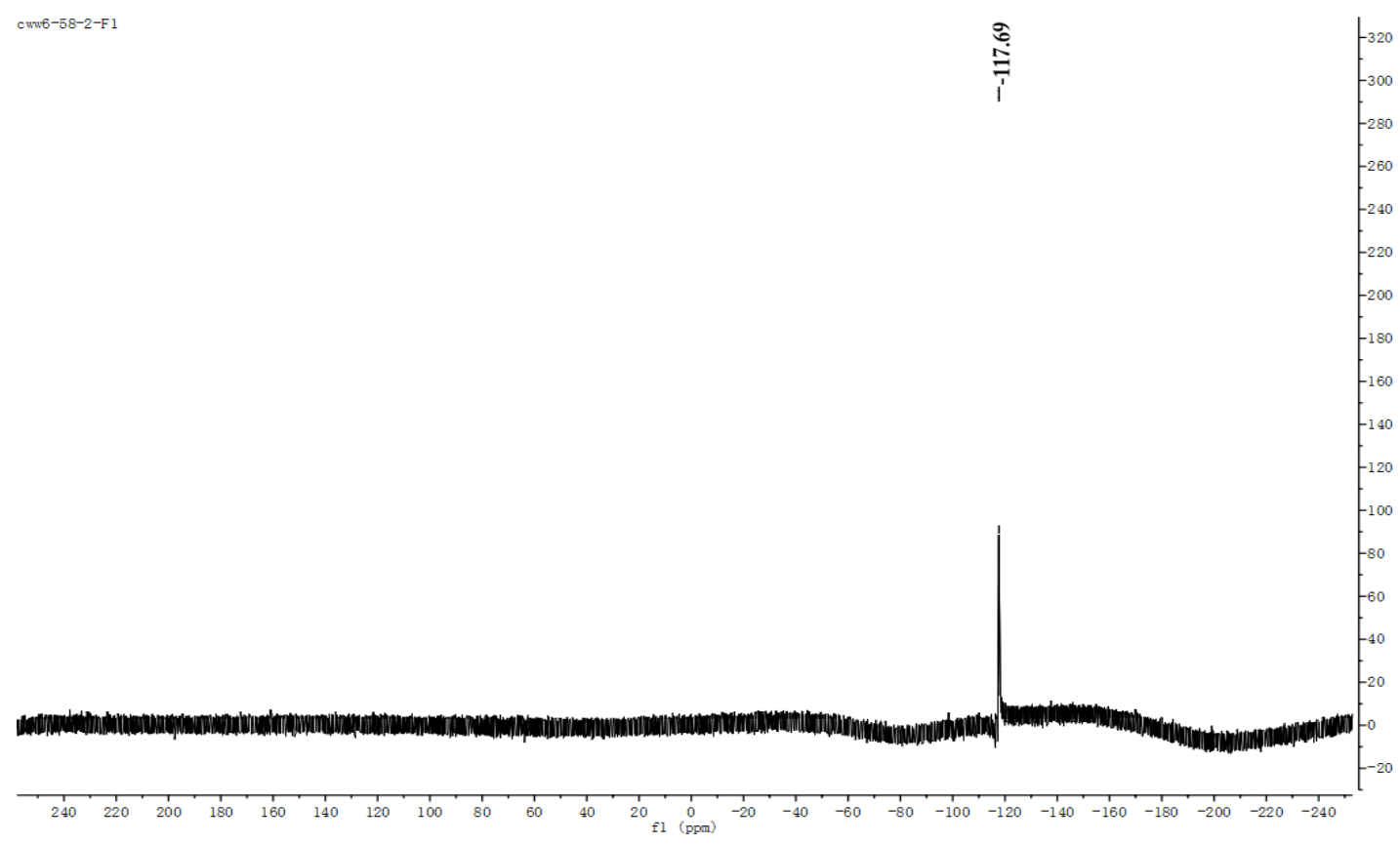




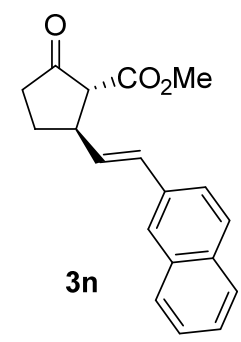

${ }^{1} \mathbf{H}$ NMR (400 MHz, $\left.\mathrm{CDCl}_{3}\right)$

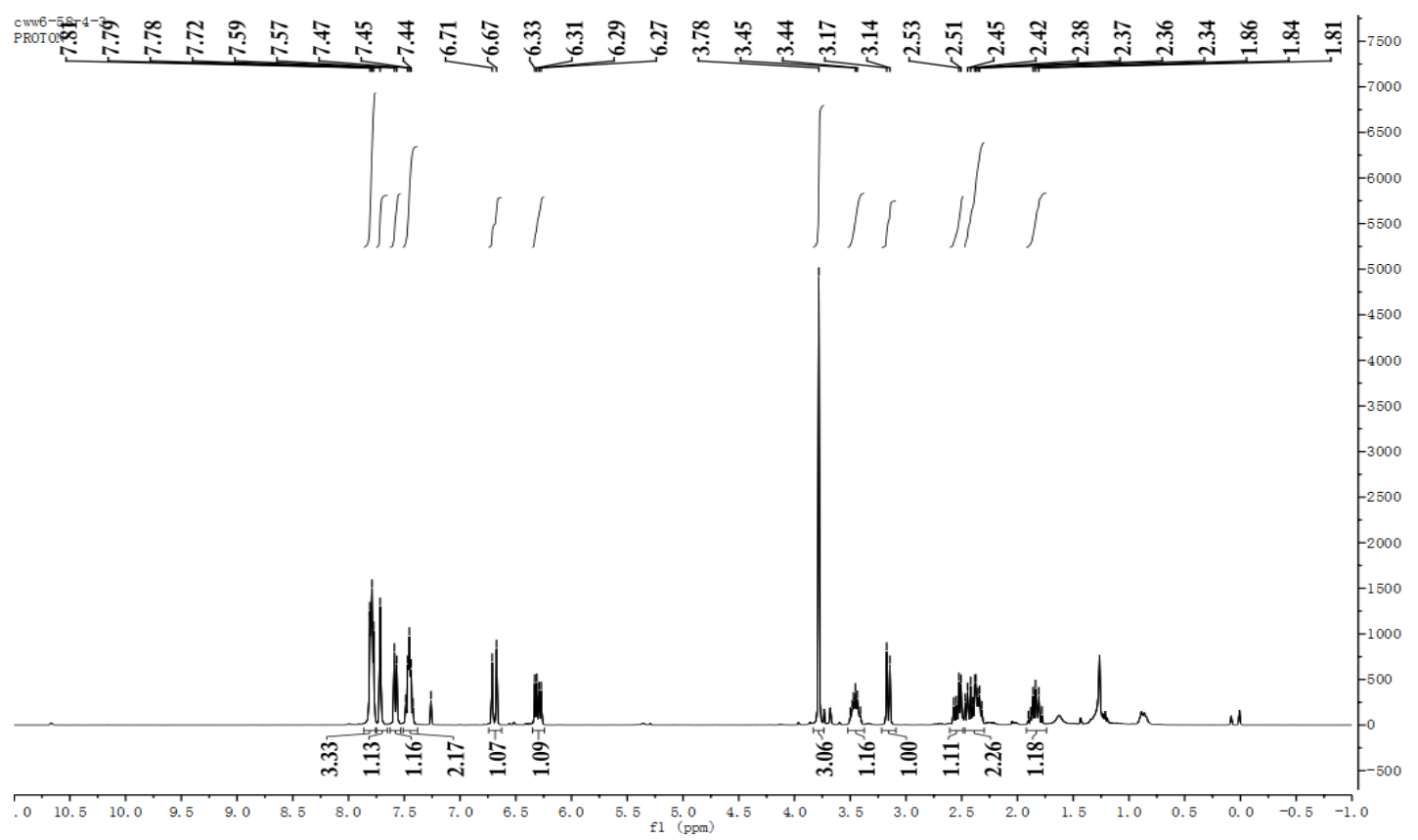

${ }^{13}$ C NMR $\left(100 \mathrm{MHz}, \mathrm{CDCl}_{3}\right)$

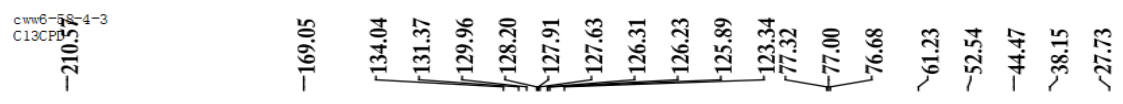

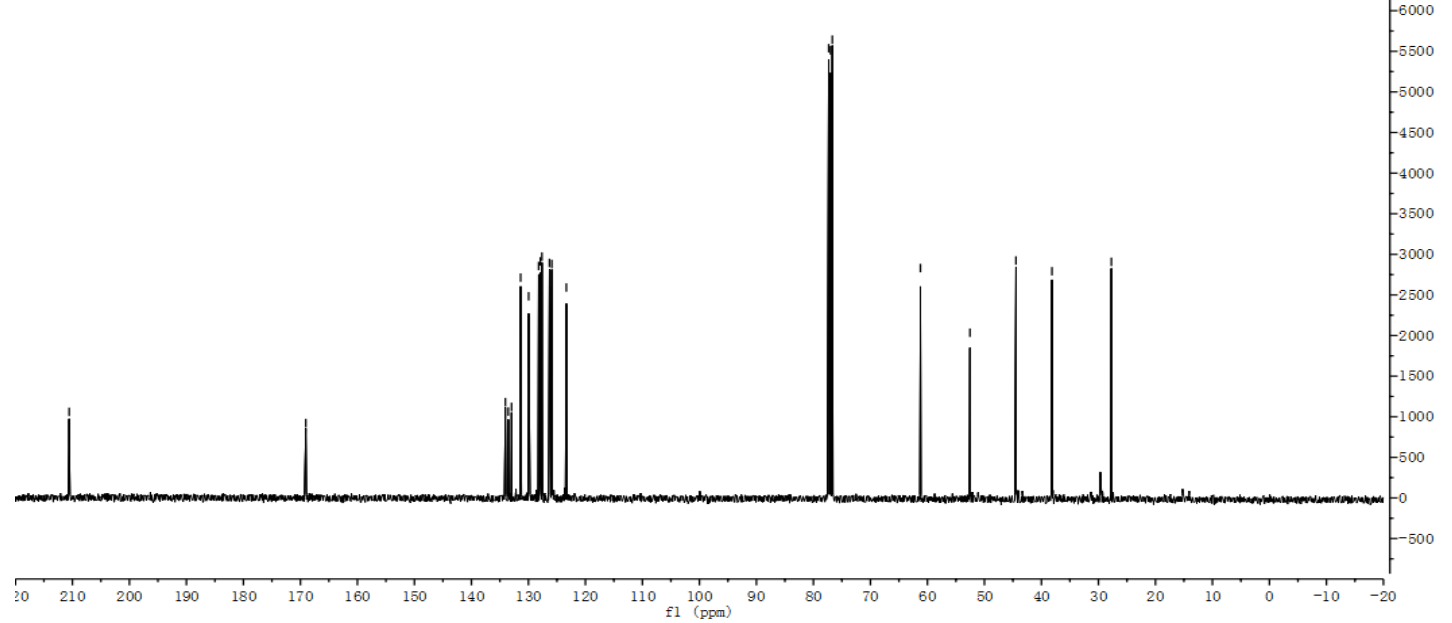




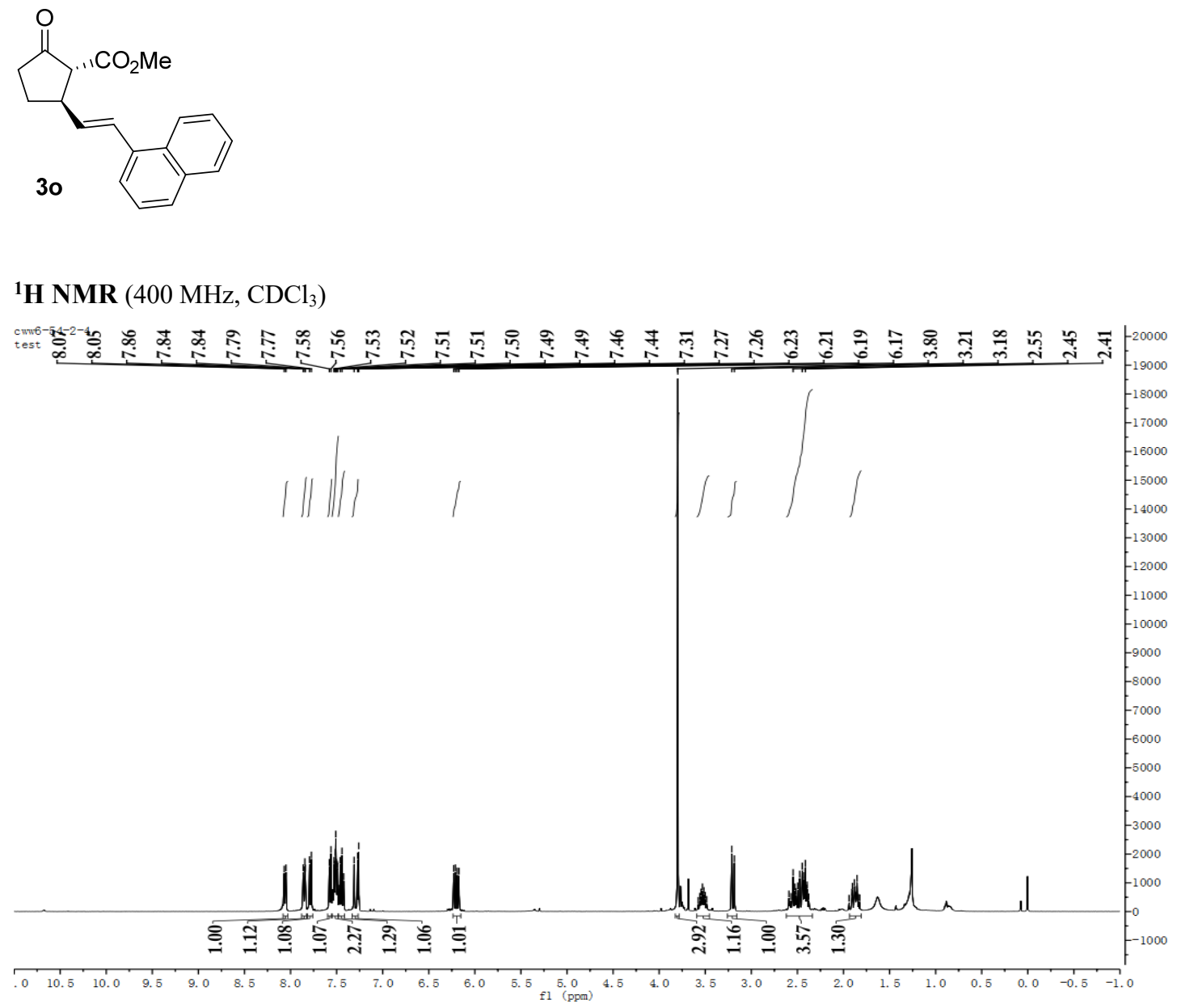

${ }^{13}$ C NMR (100 MHz, $\left.\mathrm{CDCl}_{3}\right)$

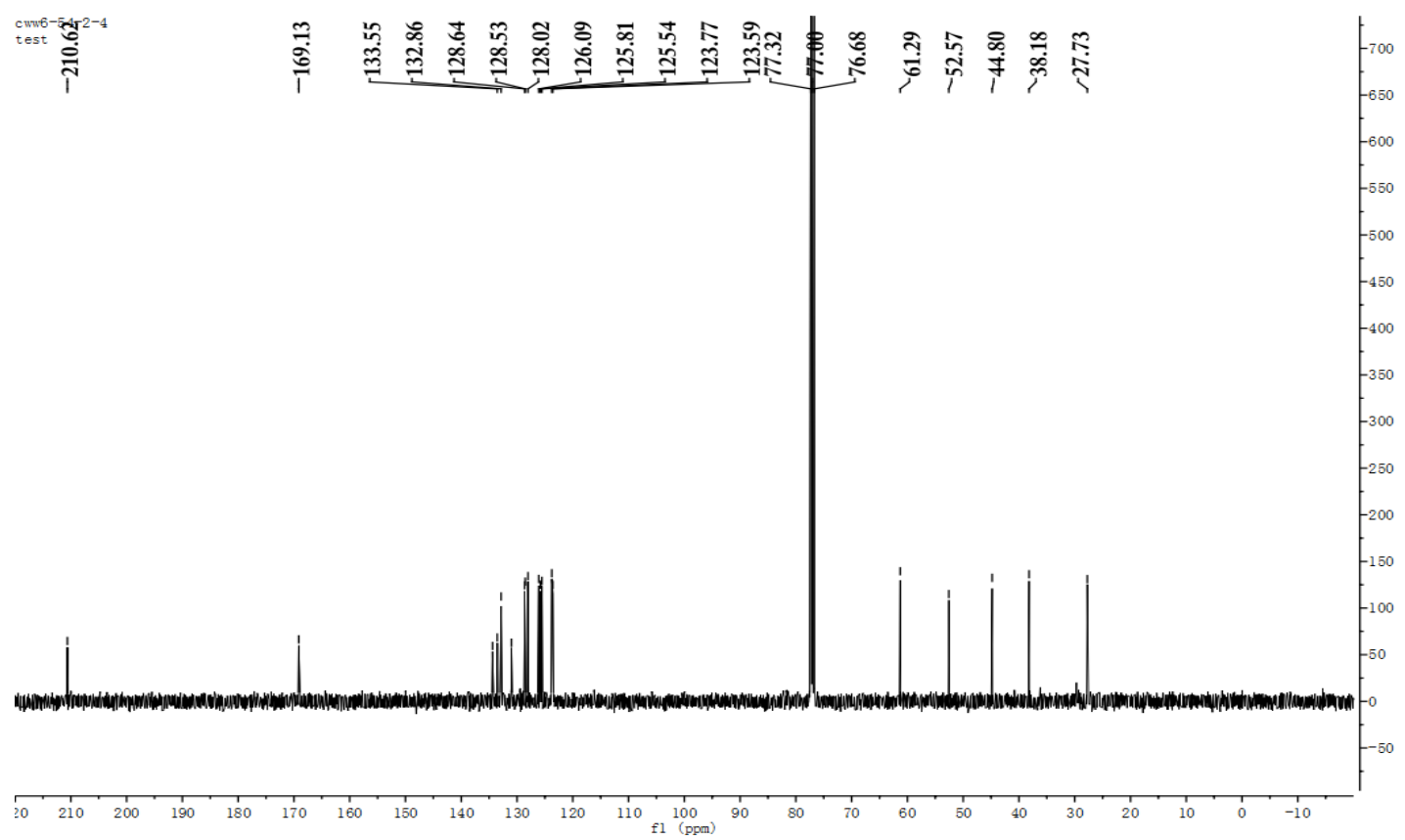


<smiles></smiles>

${ }^{1} \mathbf{H}$ NMR (400 MHz, $\left.\mathrm{CDCl}_{3}\right)$

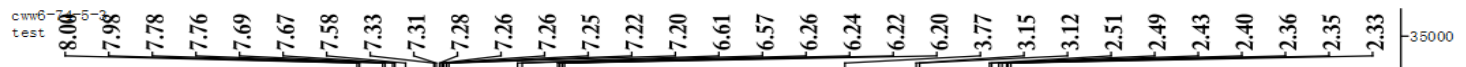

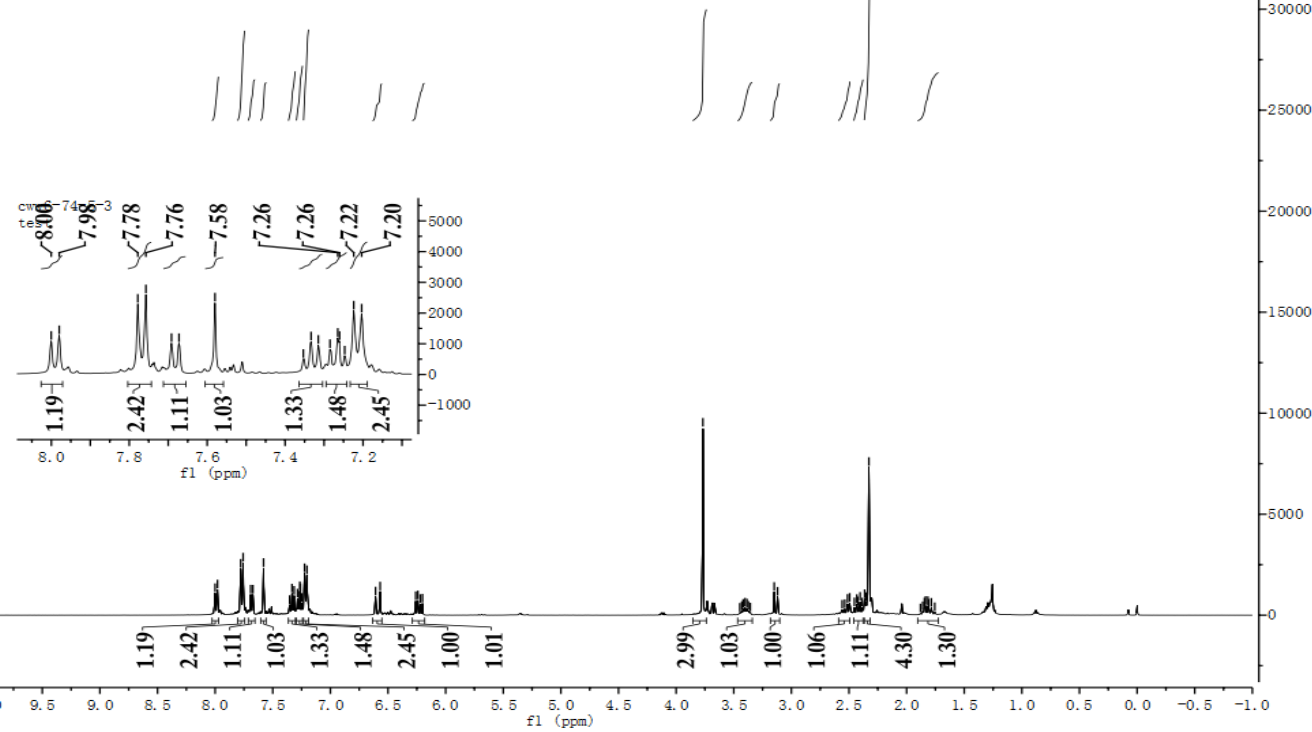

${ }^{13} \mathbf{C}$ NMR $\left(100 \mathrm{MHz}, \mathrm{CDCl}_{3}\right)$

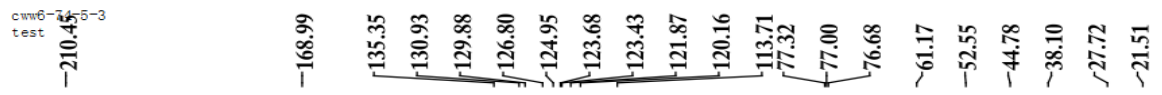

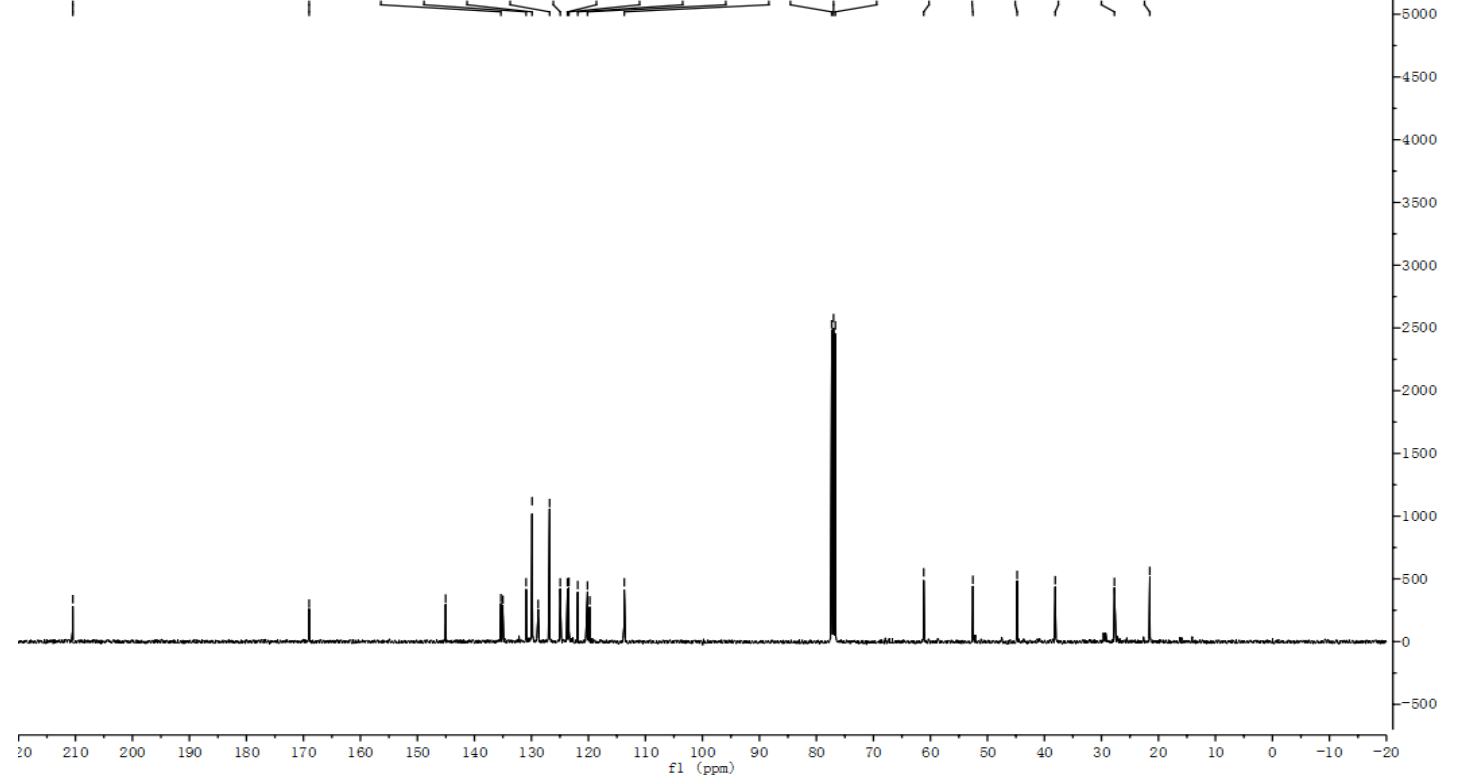




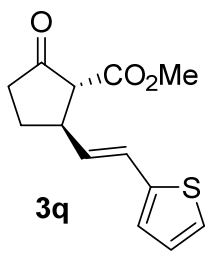

${ }^{1} \mathbf{H}$ NMR (400 MHz, $\mathrm{CDCl}_{3}$ )

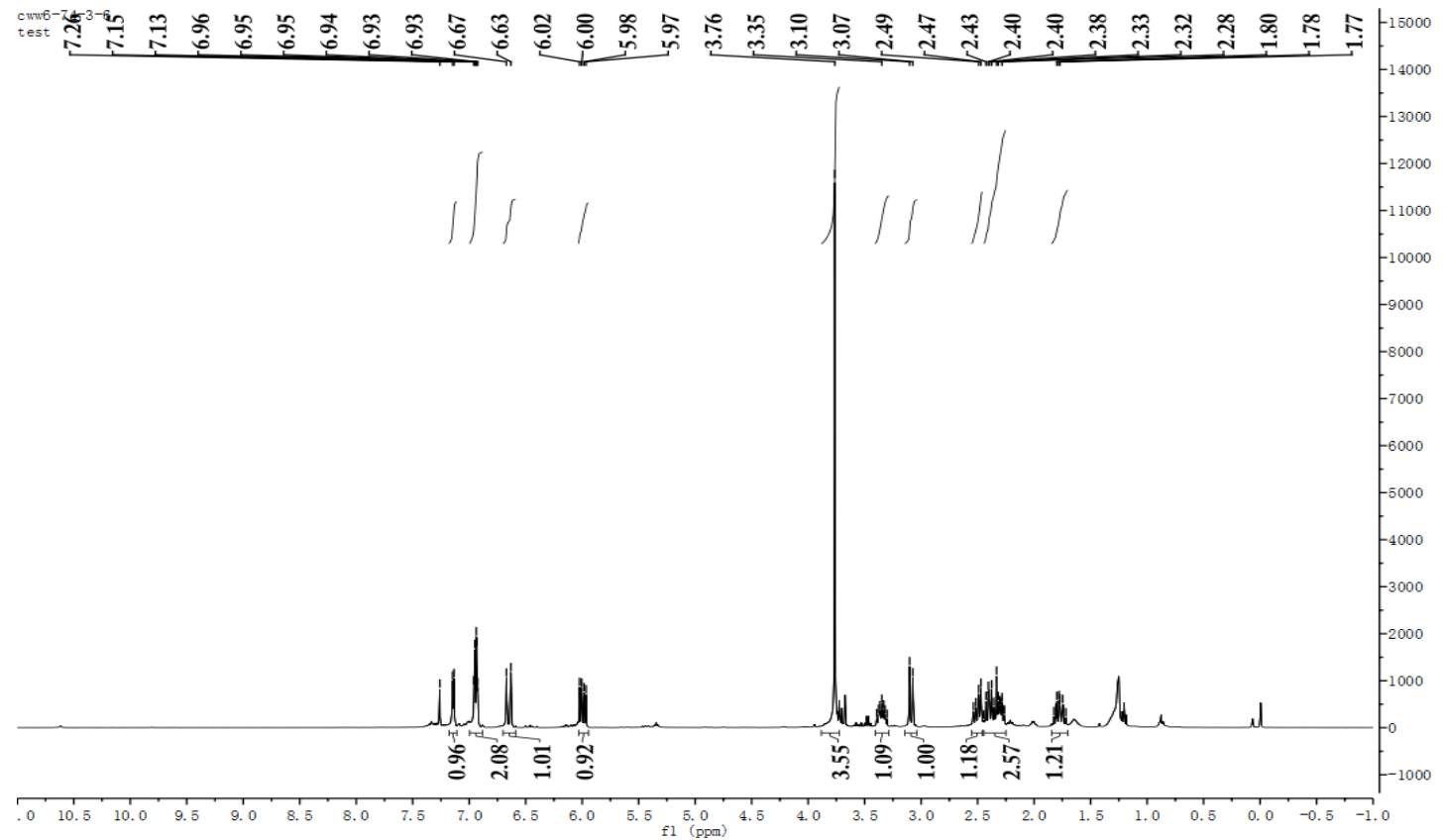

${ }^{13}$ C NMR (100 MHz, $\left.\mathrm{CDCl}_{3}\right)$

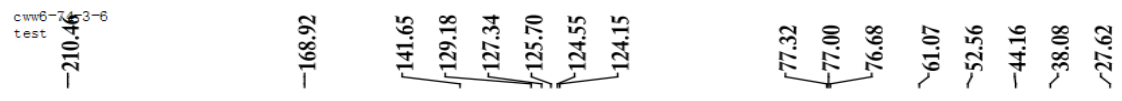

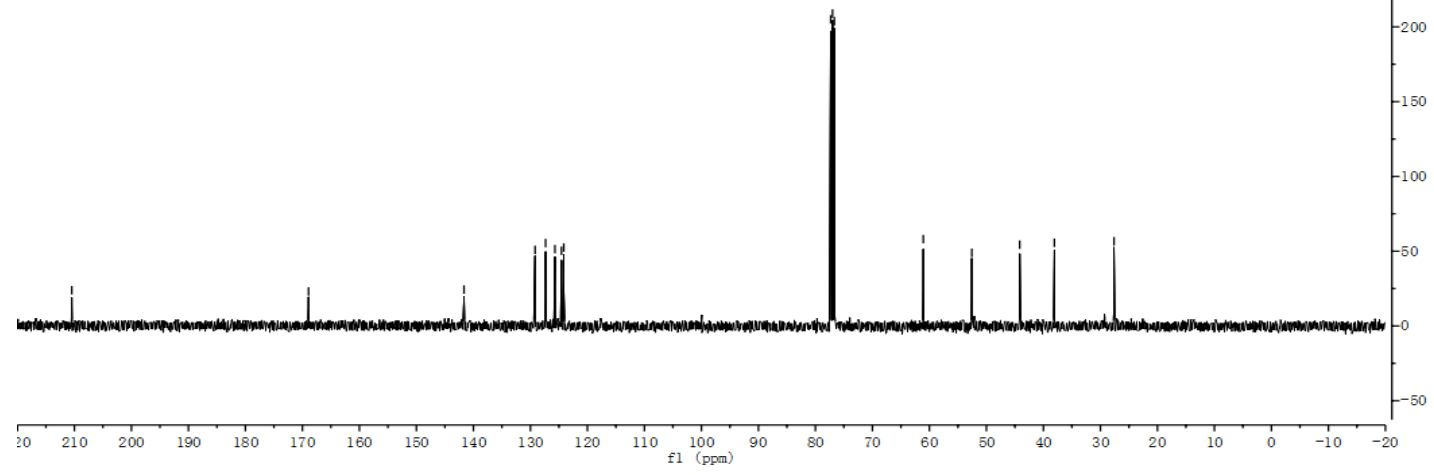




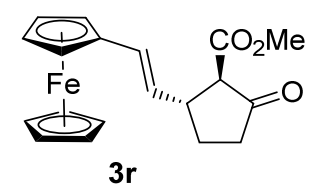

${ }^{1} \mathbf{H}$ NMR $\left(400 \mathrm{MHz}, \mathrm{CDCl}_{3}\right)$

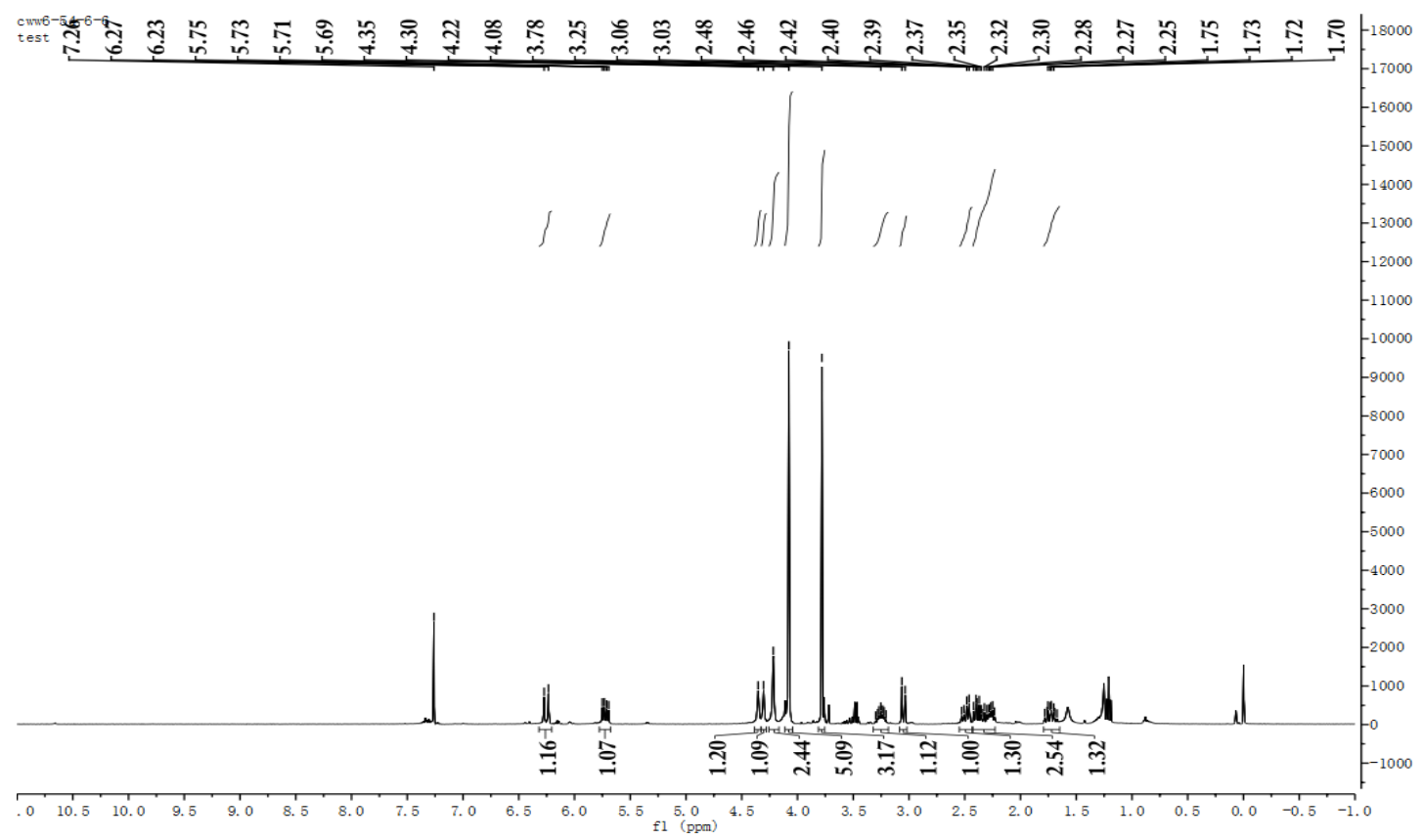

${ }^{13} \mathbf{C}$ NMR $\left(100 \mathrm{MHz}, \mathrm{CDCl}_{3}\right)$
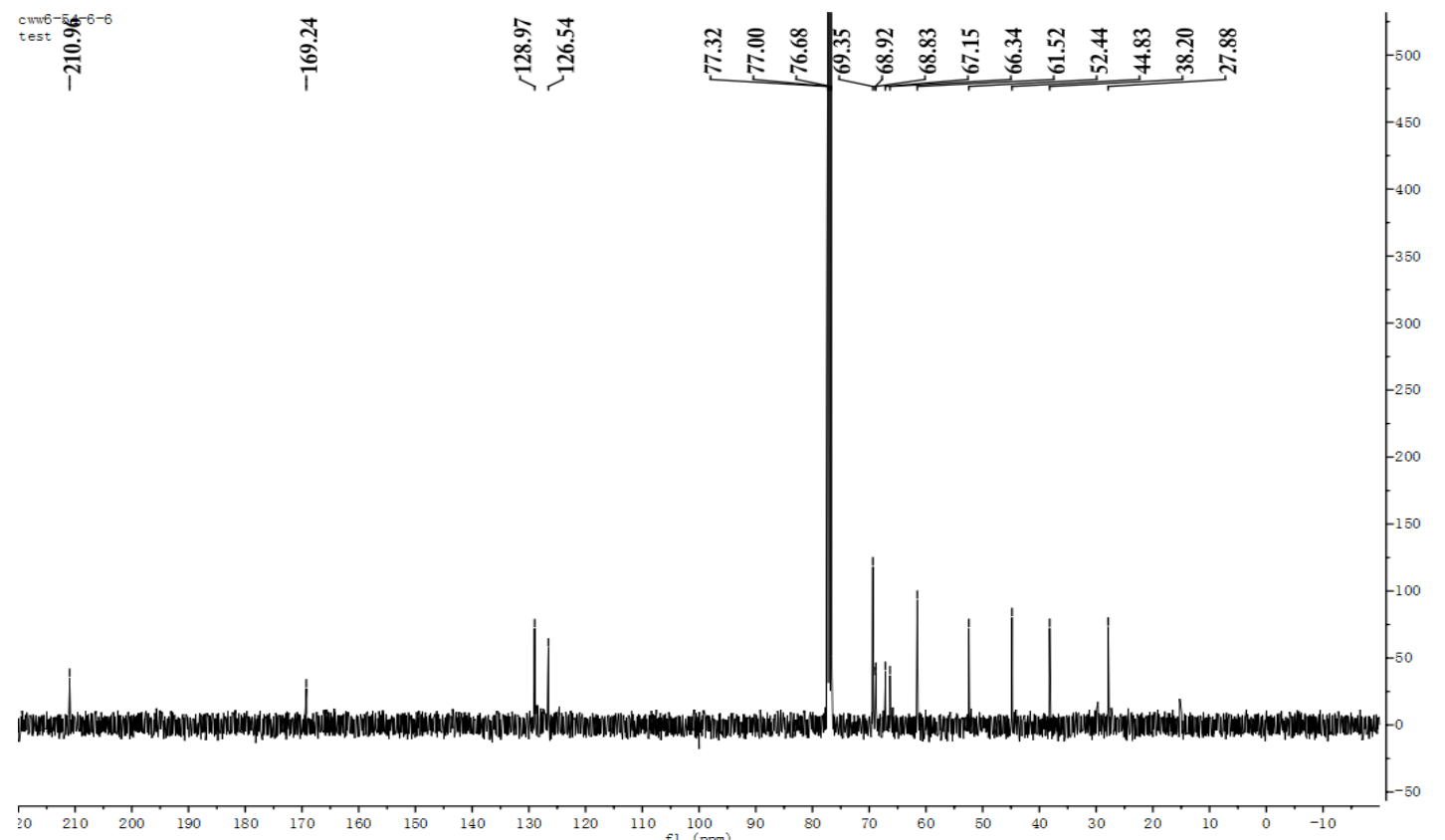

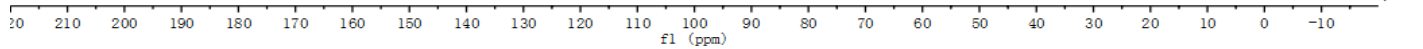




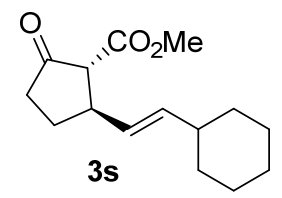

${ }^{1} \mathbf{H}$ NMR $\left(400 \mathrm{MHz}, \mathrm{CDCl}_{3}\right)$

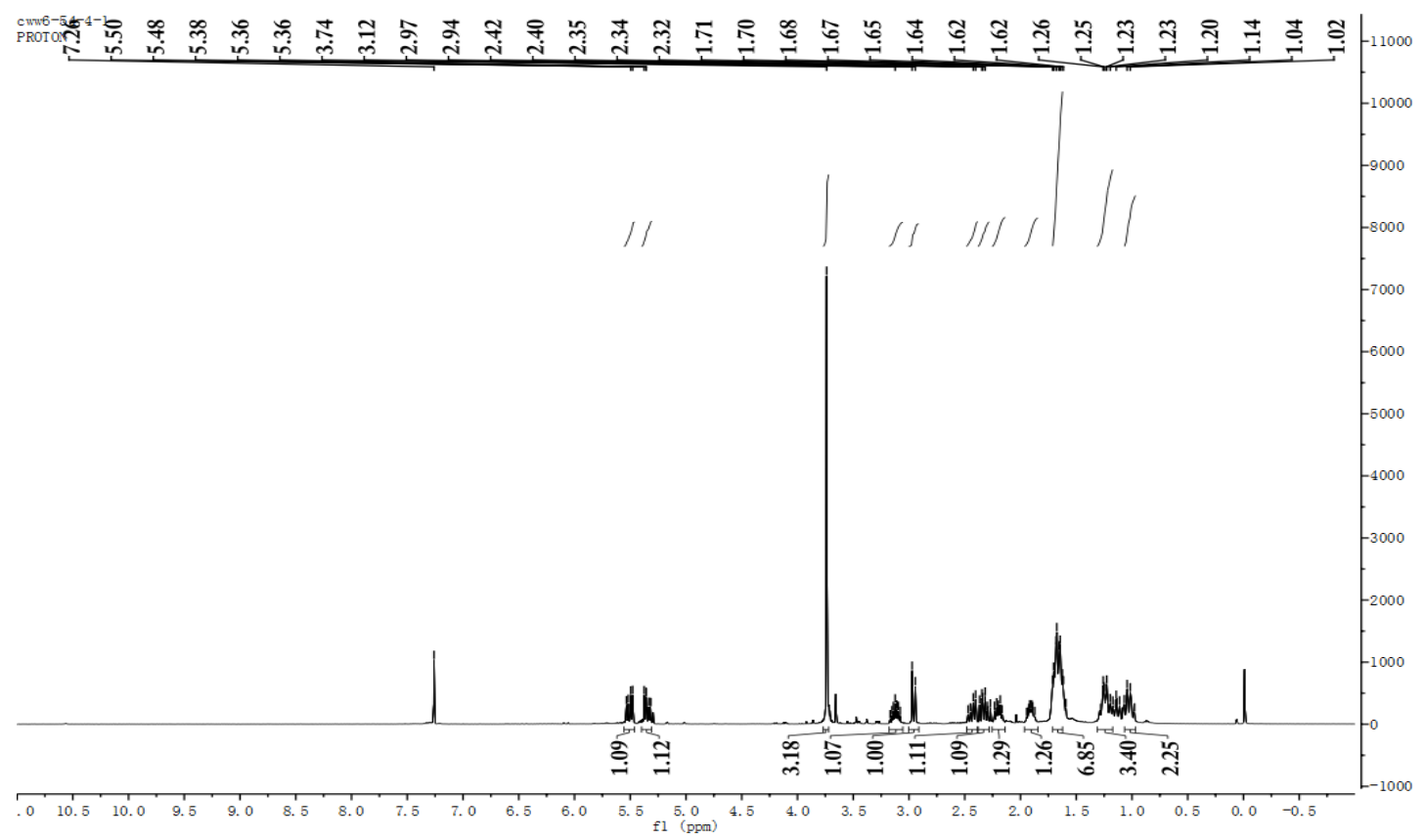

${ }^{13} \mathbf{C}$ NMR $\left(100 \mathrm{MHz}, \mathrm{CDCl}_{3}\right)$
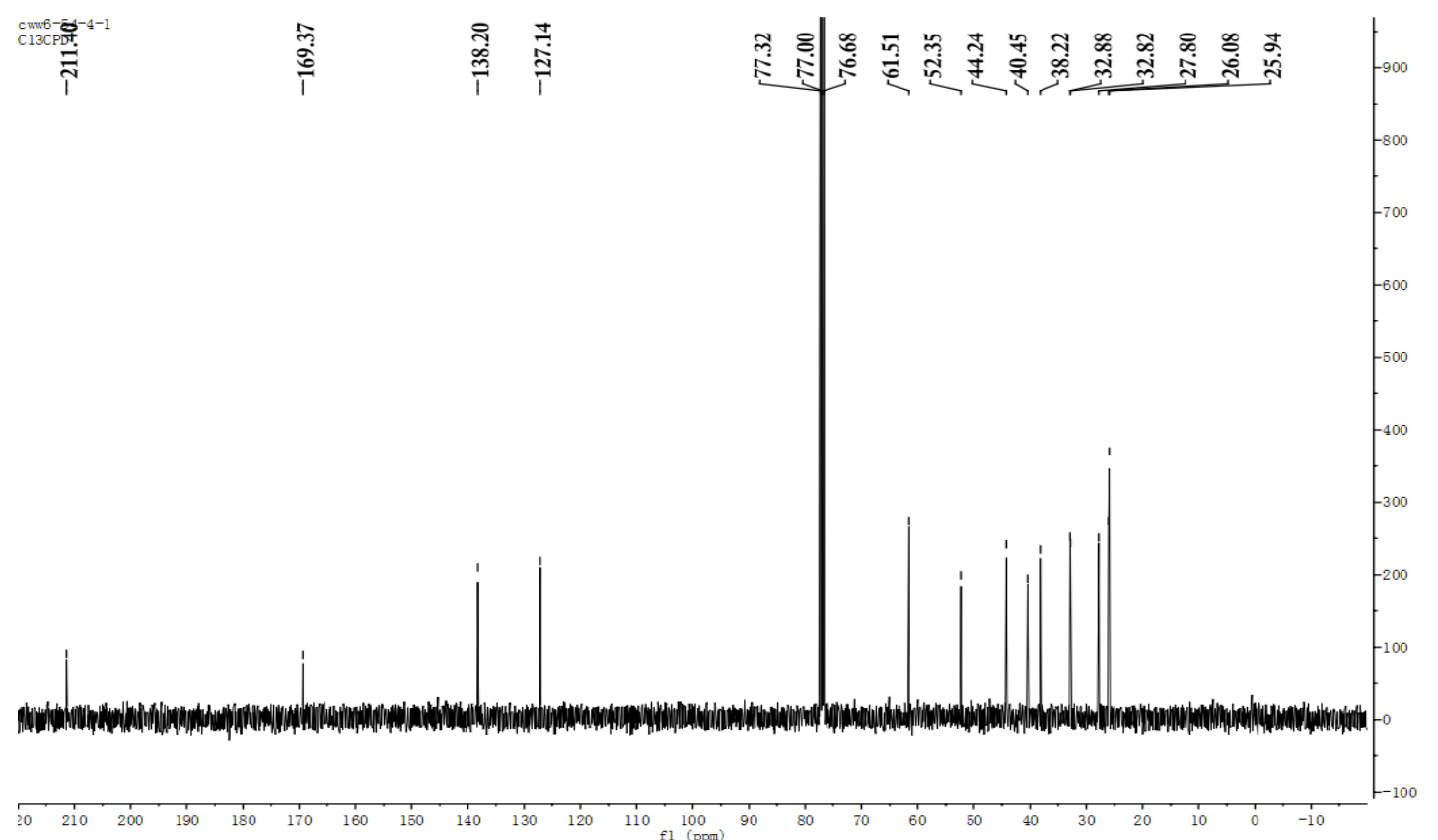


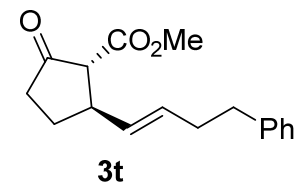

${ }^{1} \mathbf{H}$ NMR (400 MHz, $\left.\mathrm{CDCl}_{3}\right)$

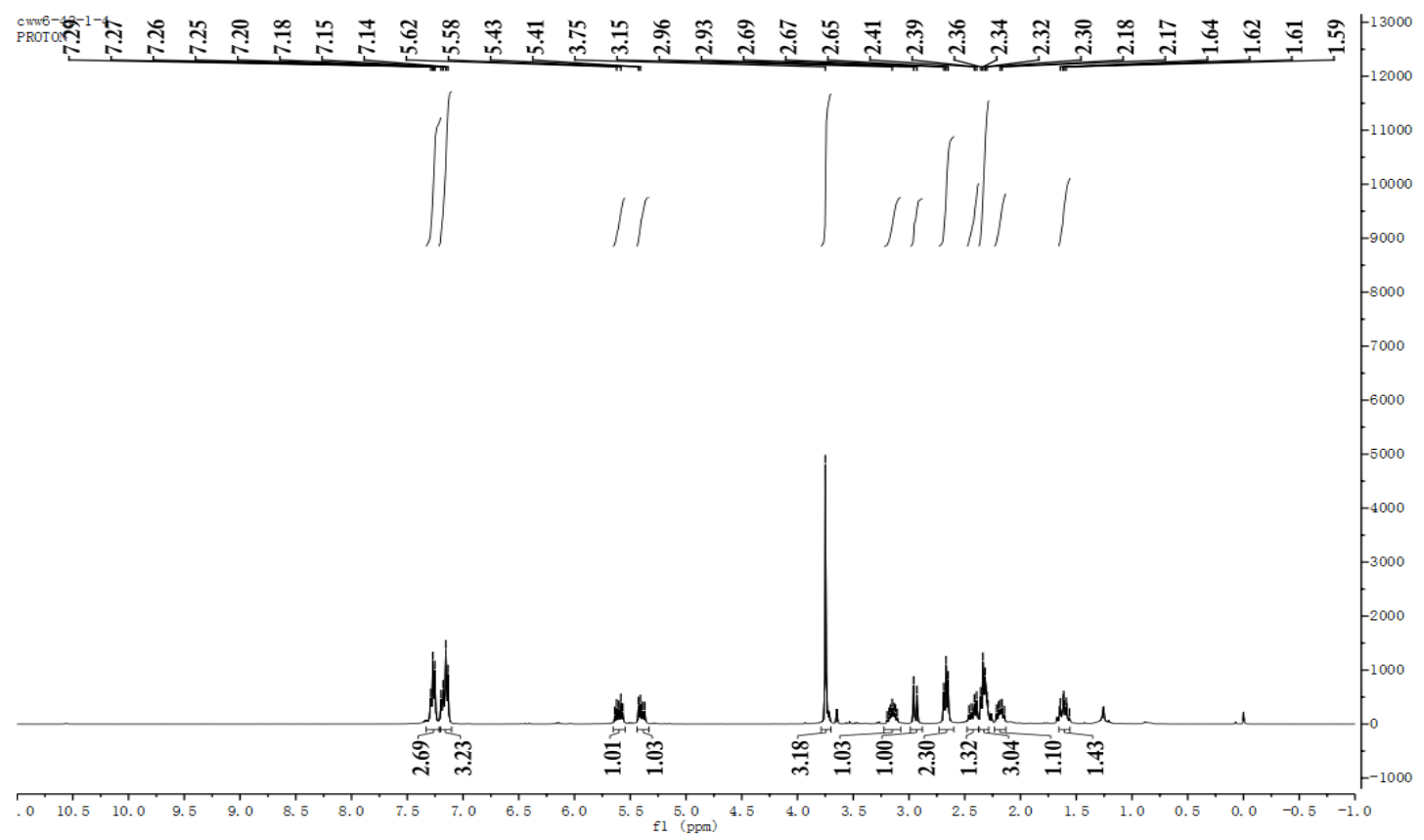

${ }^{13} \mathbf{C}$ NMR (100 MHz, $\left.\mathrm{CDCl}_{3}\right)$

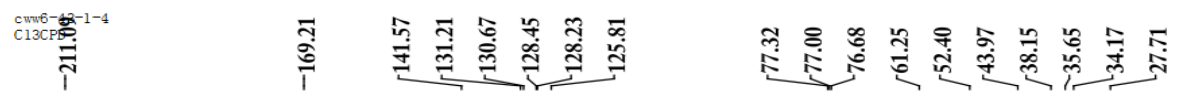

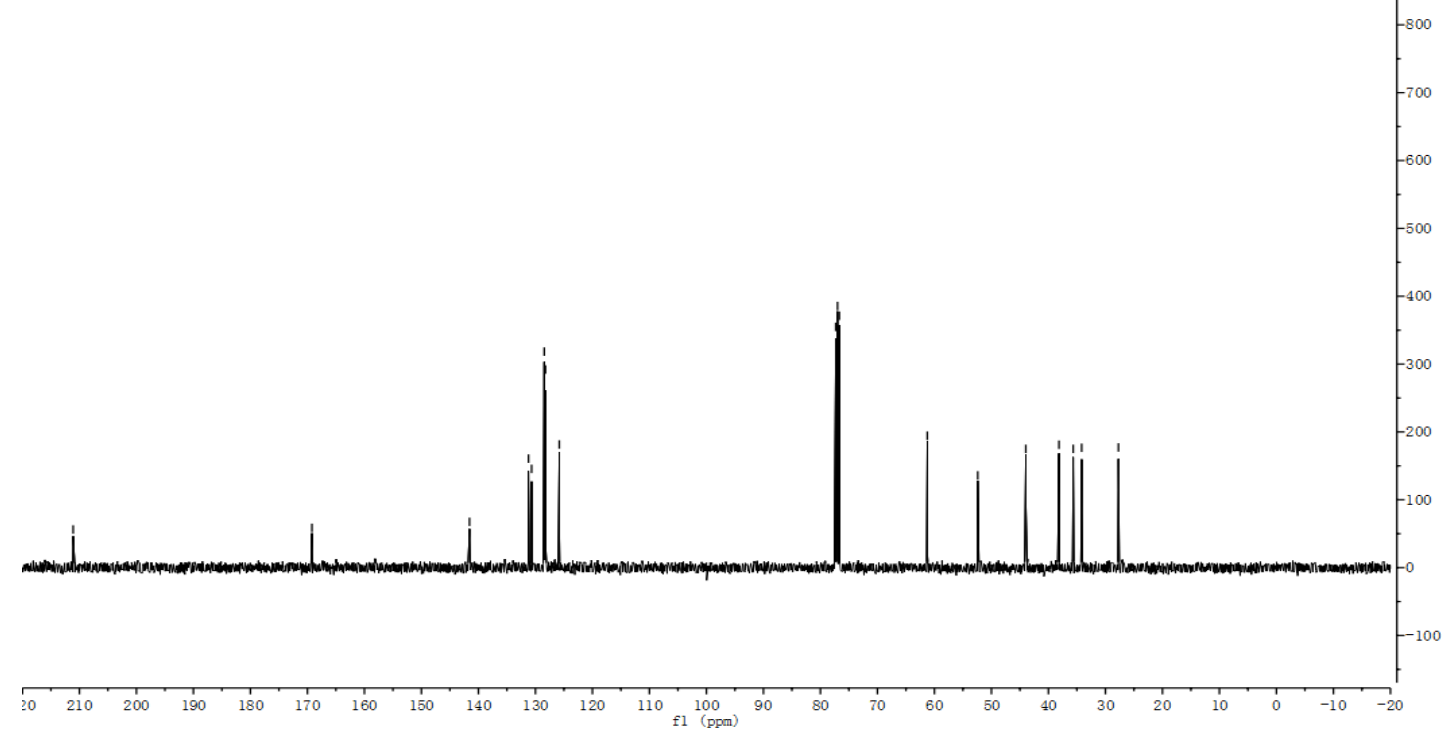




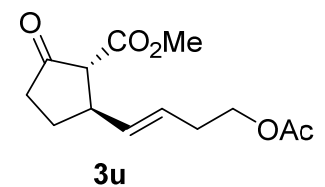

${ }^{1}$ H NMR $\left(400 \mathrm{MHz}, \mathrm{CDCl}_{3}\right)$

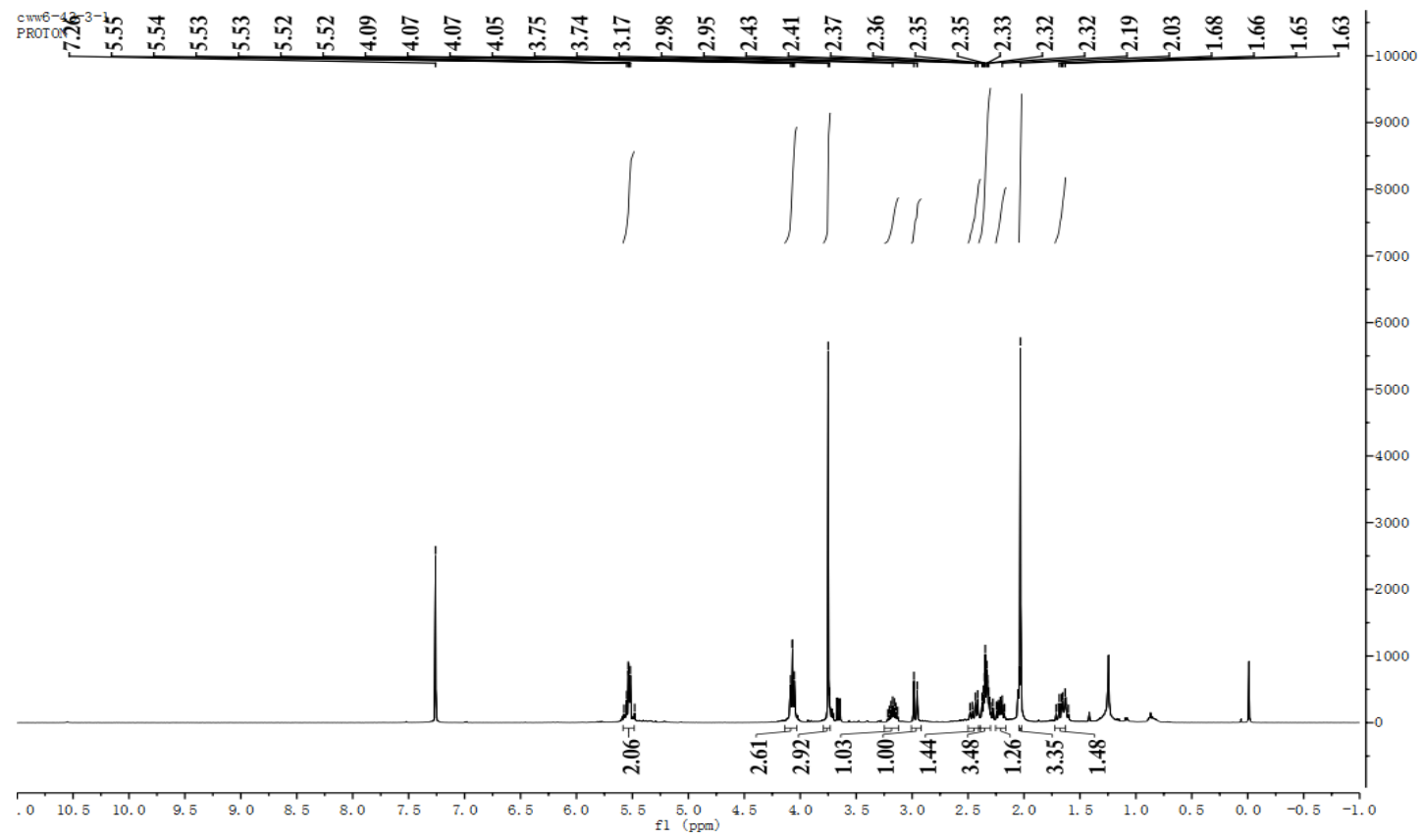

${ }^{13}$ C NMR (100 MHz, $\left.\mathrm{CDCl}_{3}\right)$

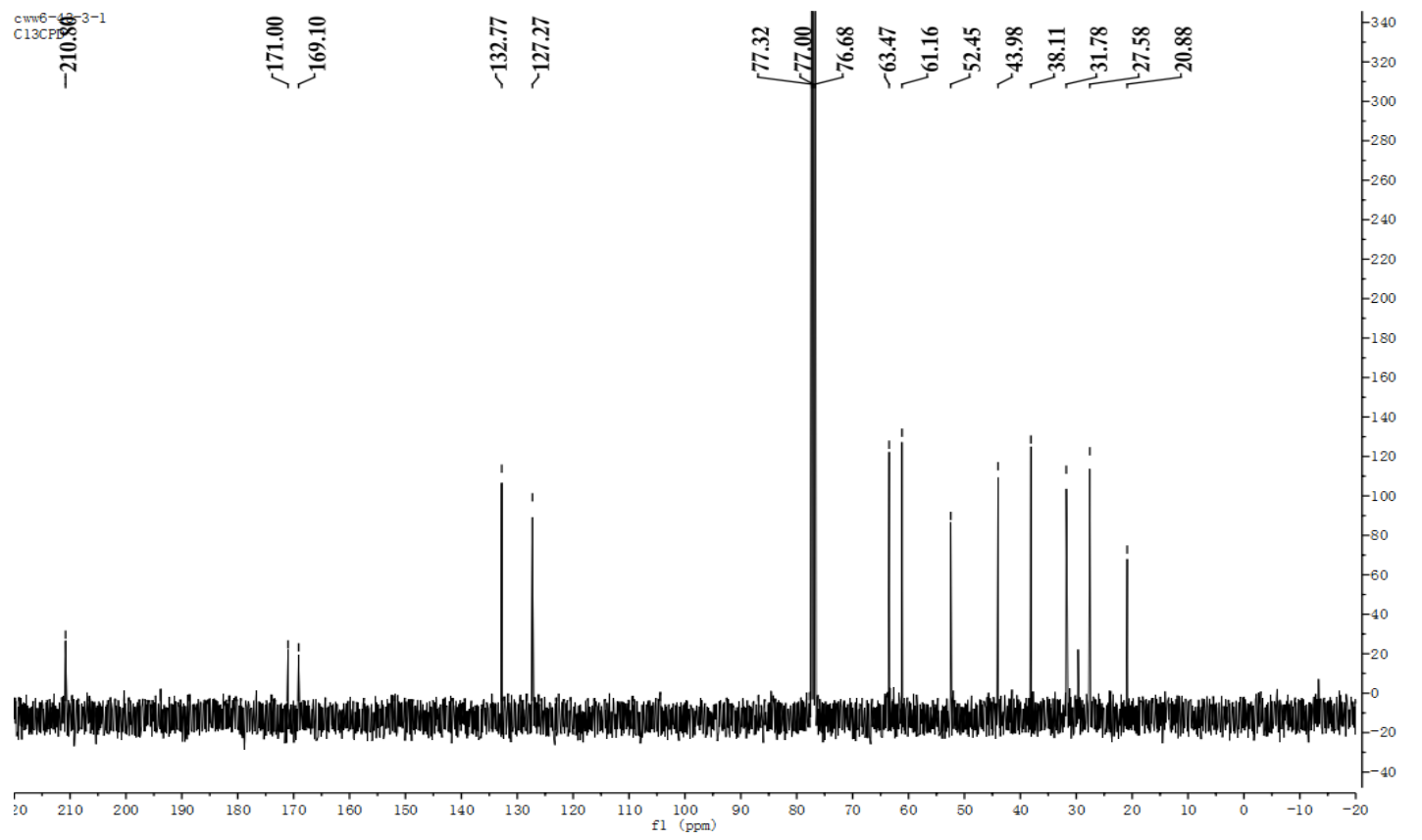




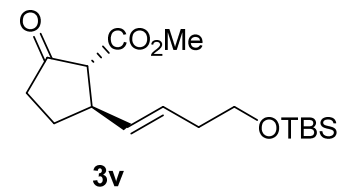

${ }^{1} \mathbf{H}$ NMR (400 MHz, $\mathrm{CDCl}_{3}$ )

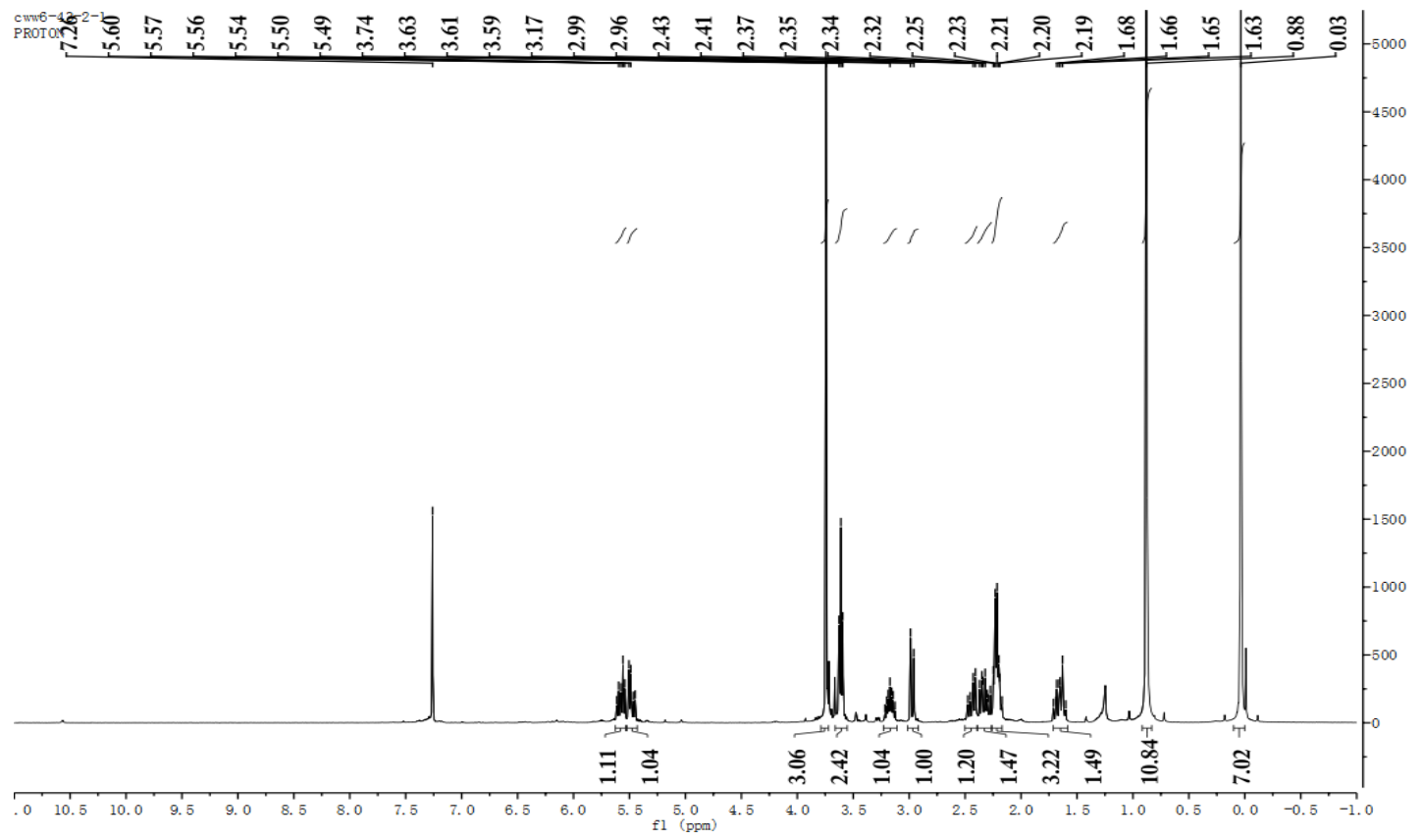

${ }^{13}$ C NMR (100 MHz, $\left.\mathrm{CDCl}_{3}\right)$

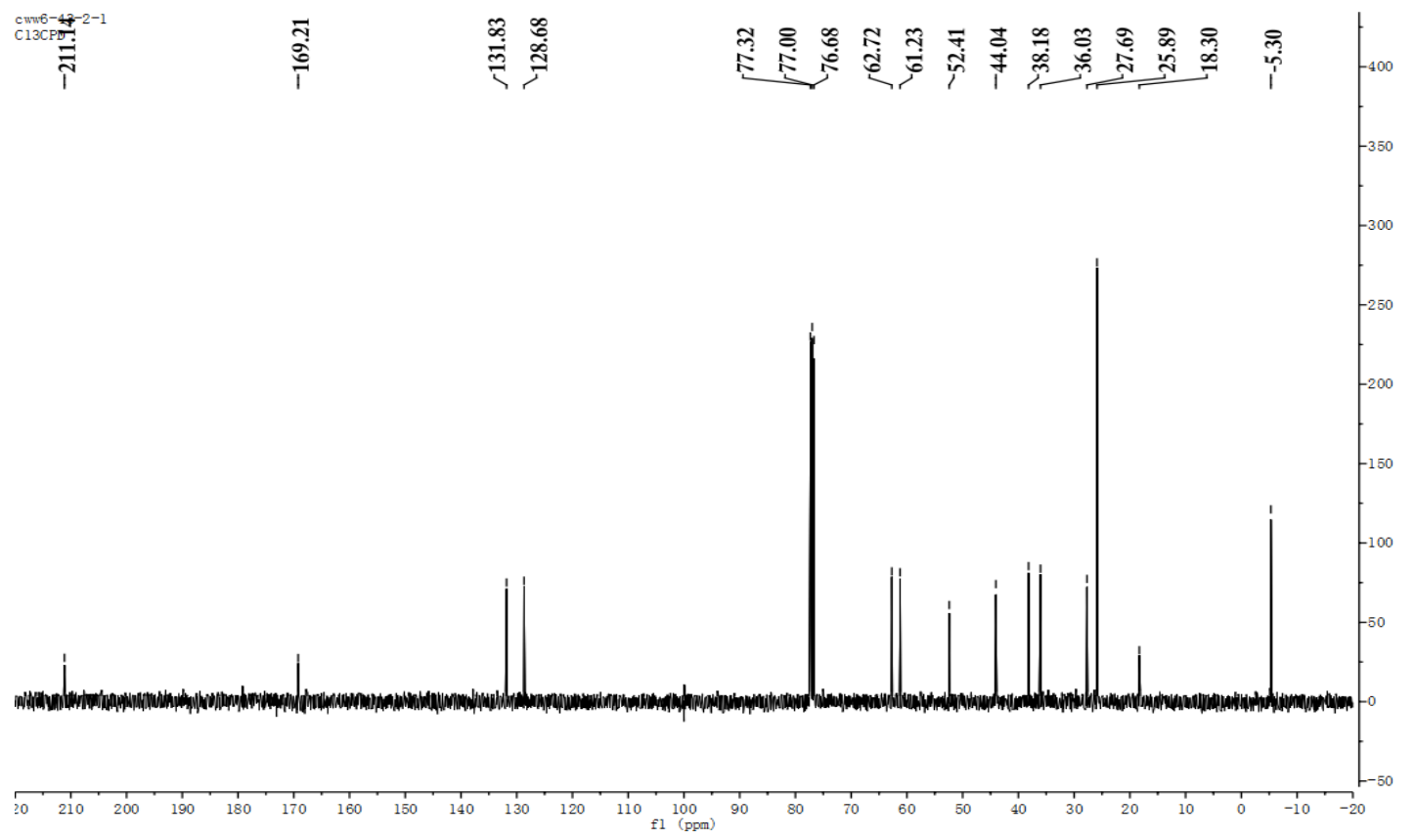


<smiles>COC(=O)[C@H]1C(=O)CCC=C[C@H]1c1ccccc1</smiles>

$4 a$

${ }^{1} \mathbf{H}$ NMR (400 MHz, $\mathrm{CDCl}_{3}$ )

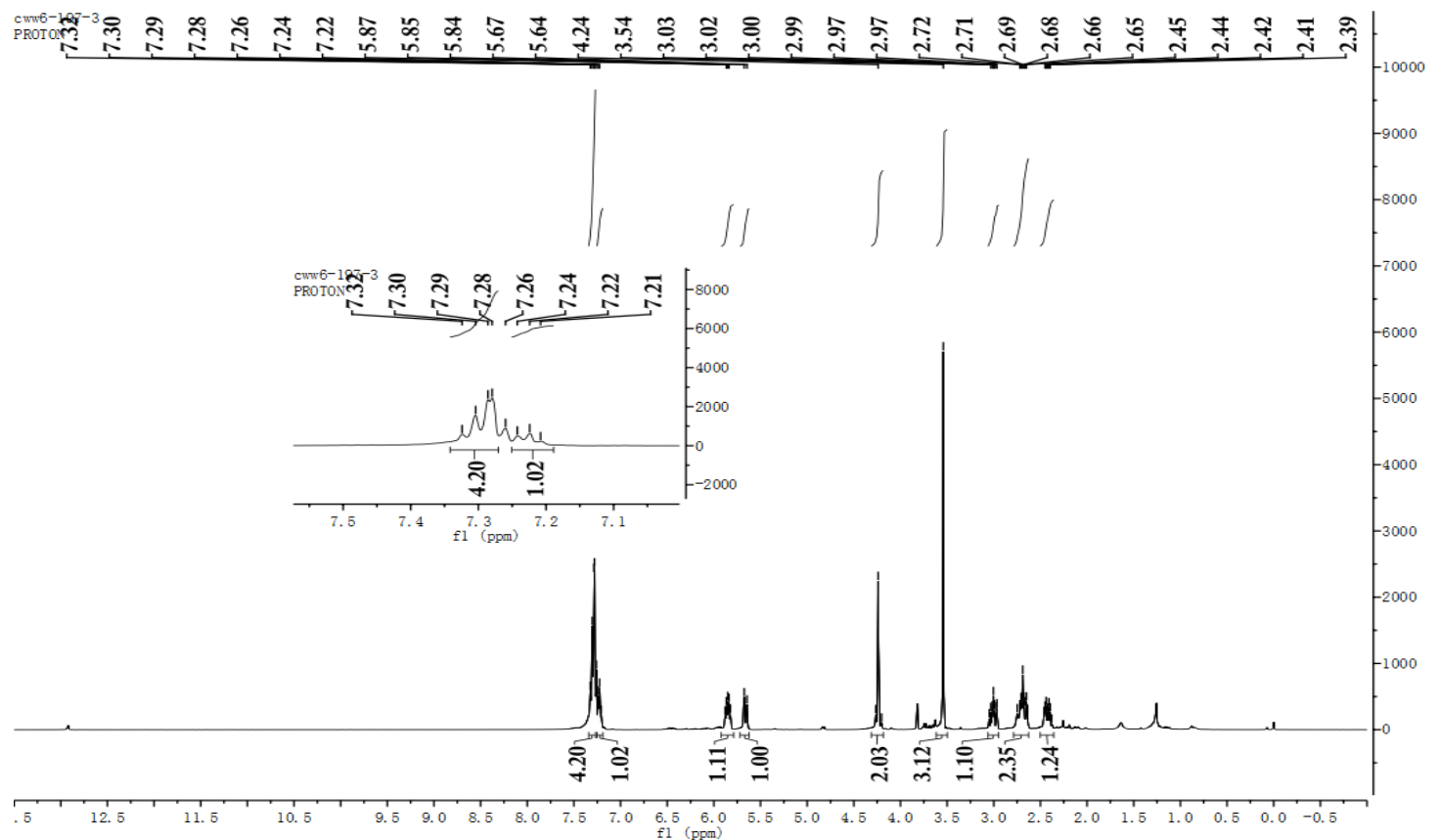

${ }^{13}$ C NMR (100 MHz, $\left.\mathrm{CDCl}_{3}\right)$

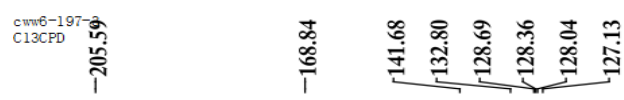

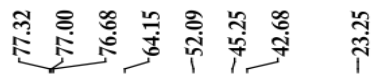

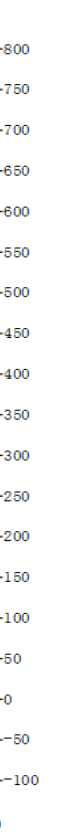


<smiles>CCOC(=O)[C@H]1C(=O)CCC=C[C@H]1c1ccccc1</smiles>

4b

${ }^{1} \mathbf{H}$ NMR (400 MHz, $\left.\mathrm{CDCl}_{3}\right)$

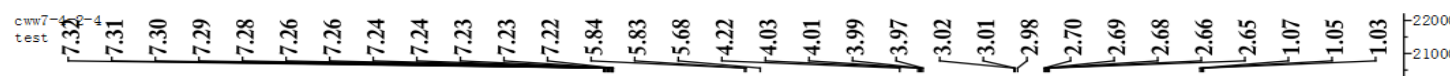

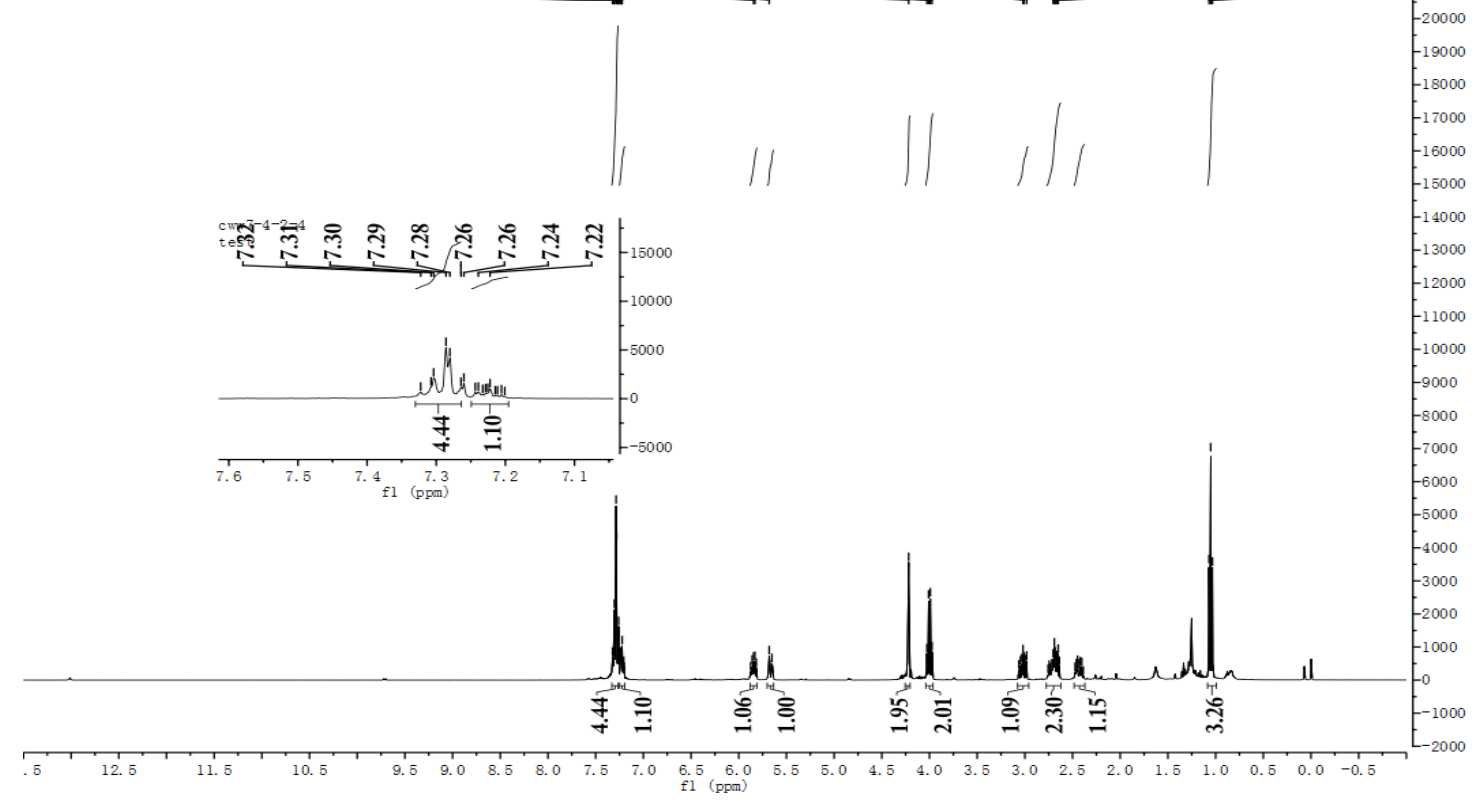

${ }^{13} \mathbf{C}$ NMR $\left(100 \mathrm{MHz}, \mathrm{CDCl}_{3}\right)$

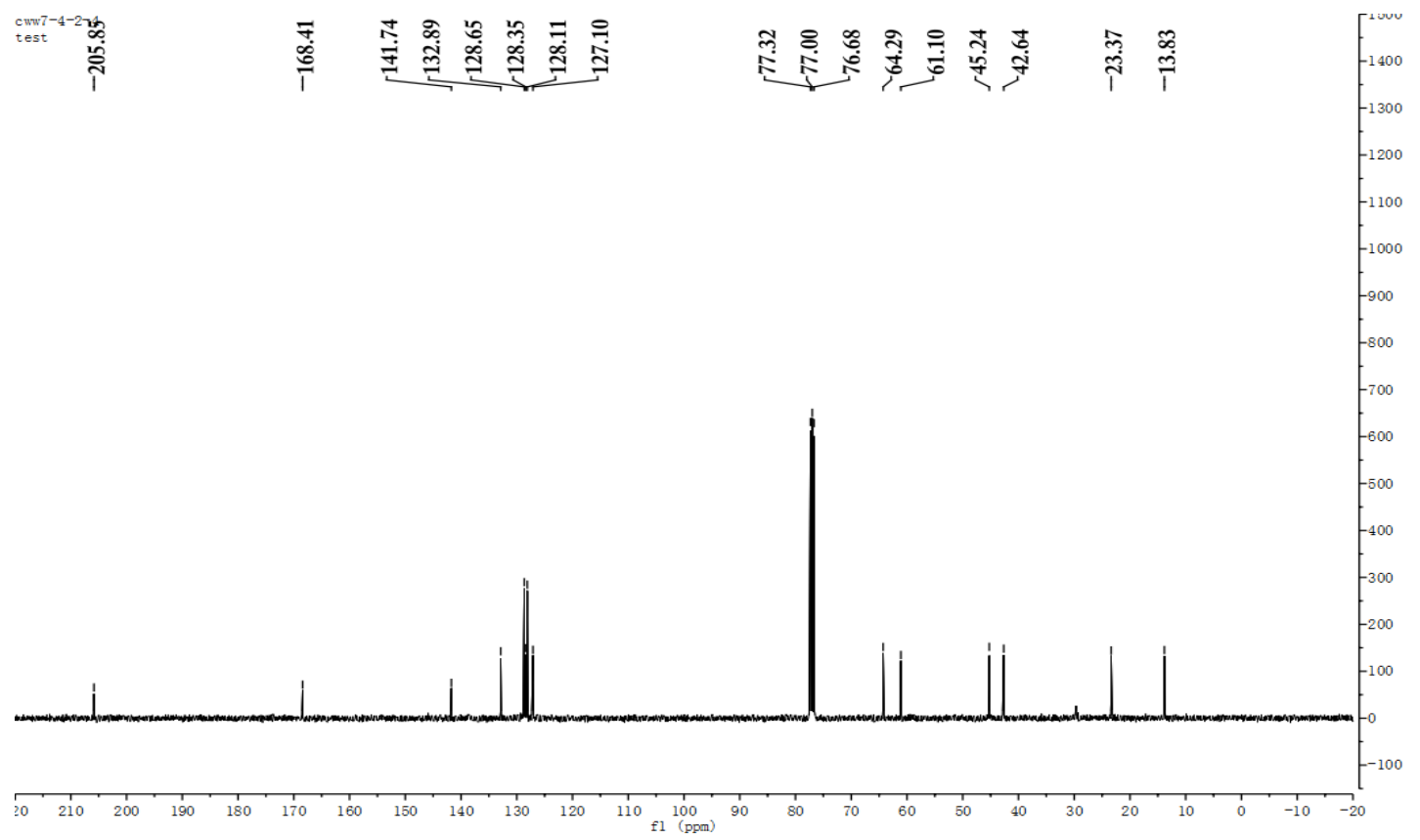




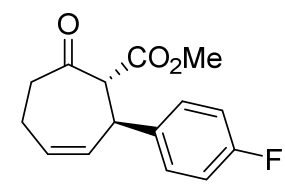

4c

${ }^{1} \mathbf{H}$ NMR $\left(400 \mathrm{MHz}, \mathrm{CDCl}_{3}\right)$

PRoror
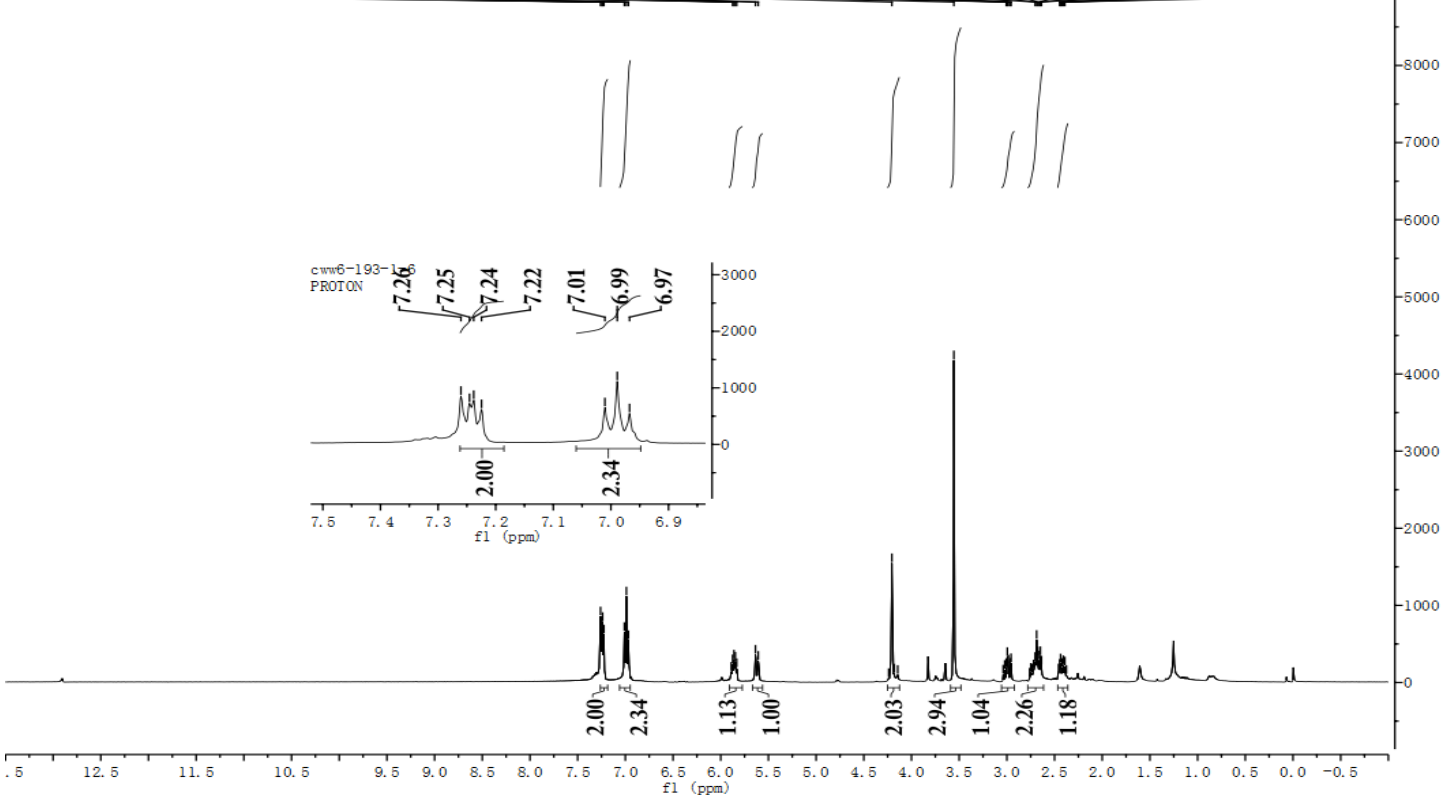

${ }^{13} \mathrm{C}$ NMR $\left(100 \mathrm{MHz}, \mathrm{CDCl}_{3}\right)$

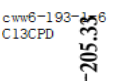

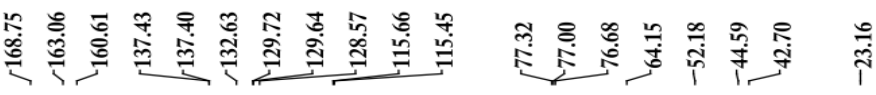

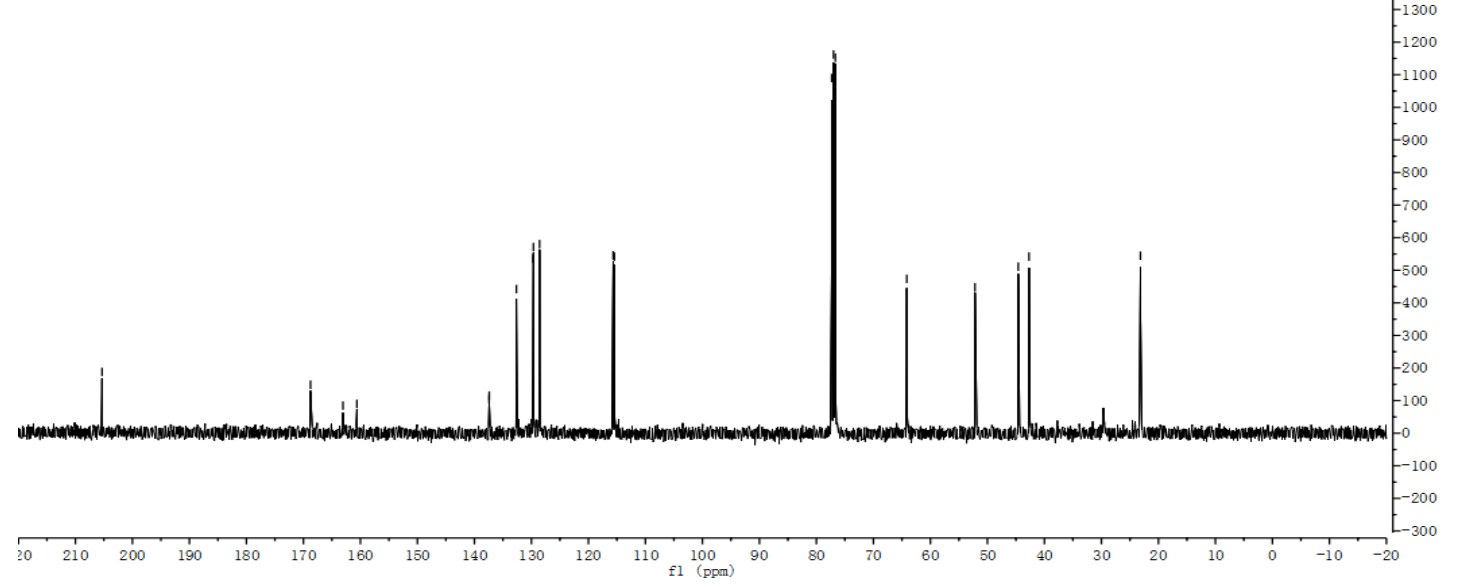


${ }^{19}$ F NMR (376 MHz, $\left.\mathrm{CDCl}_{3}\right)$

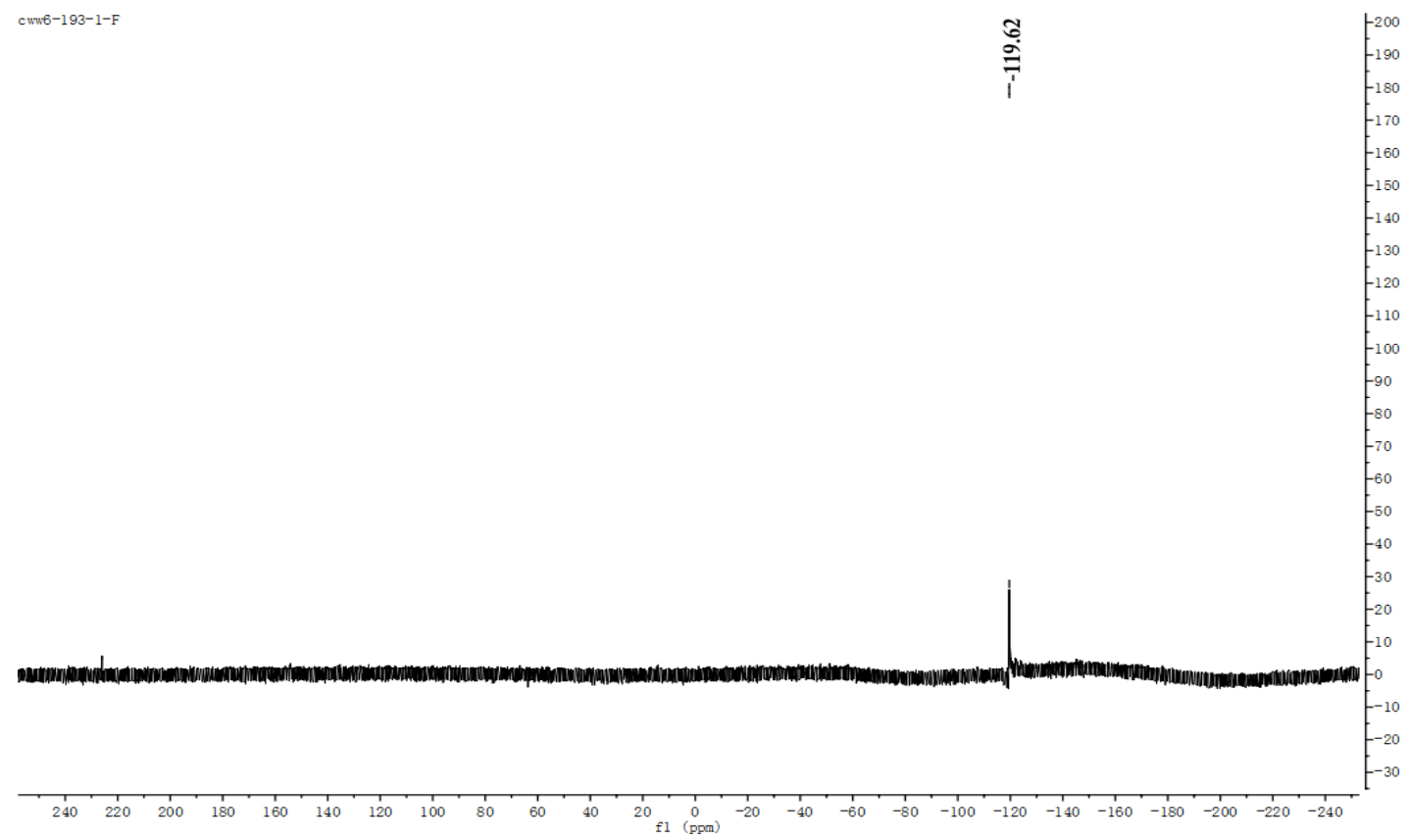


<smiles>COC(=O)[C@H]1C=CCCC(=O)[C@H]1c1ccc(C(F)(F)F)cc1</smiles>

4d

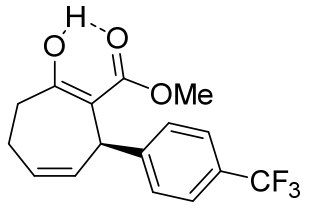

enol form

keto:enol $=8.3: 1$

${ }^{1} \mathbf{H}$ NMR $\left(400 \mathrm{MHz}, \mathrm{CDCl}_{3}\right)$

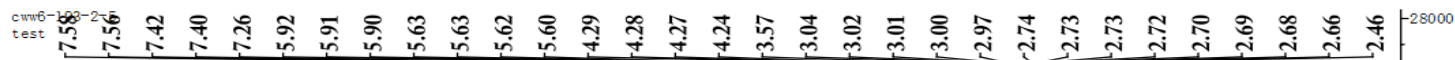

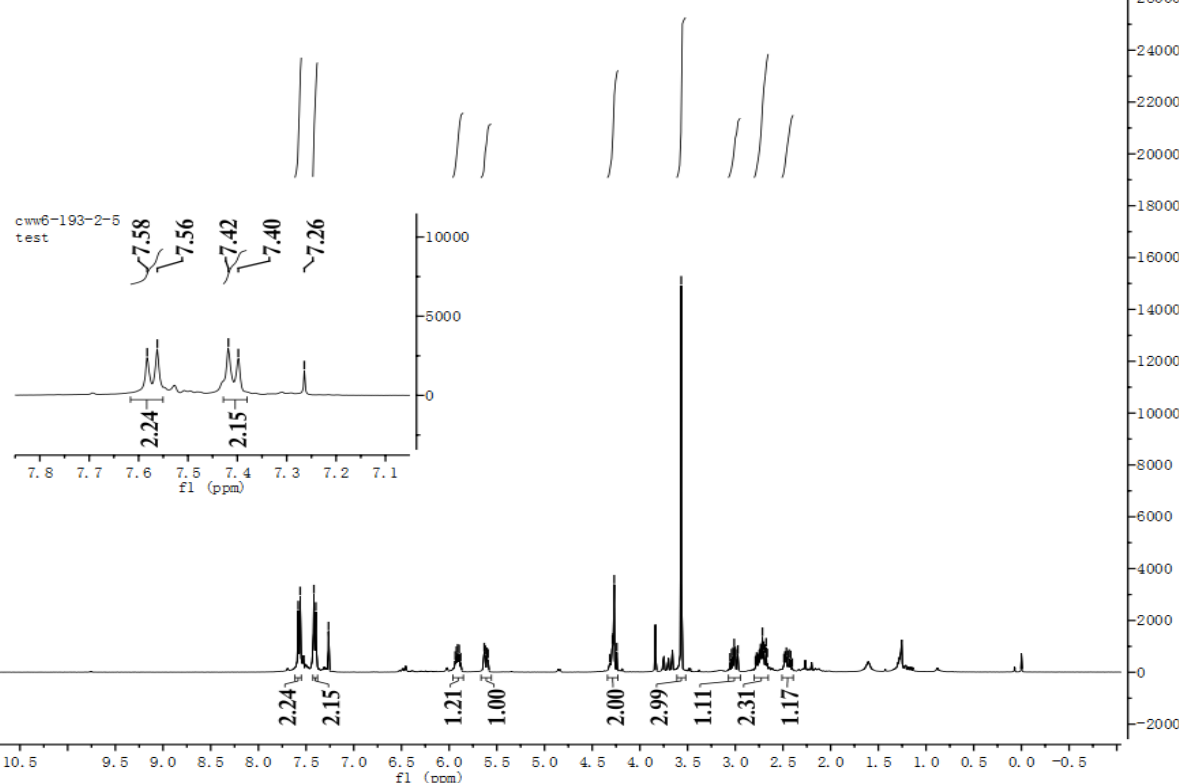

${ }^{13}$ C NMR $\left(100 \mathrm{MHz}, \mathrm{CDCl}_{3}\right)$

空

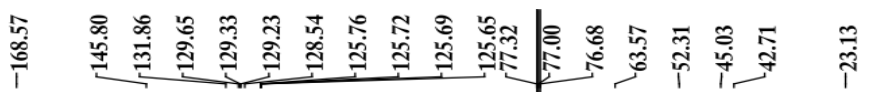

\begin{tabular}{l}
-750 \\
-700 \\
650 \\
-600 \\
-550 \\
-500 \\
-450 \\
-400 \\
-350 \\
-300 \\
-250 \\
-200 \\
-150 \\
100 \\
50 \\
\hline
\end{tabular}

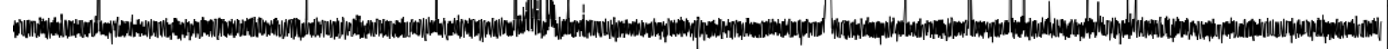

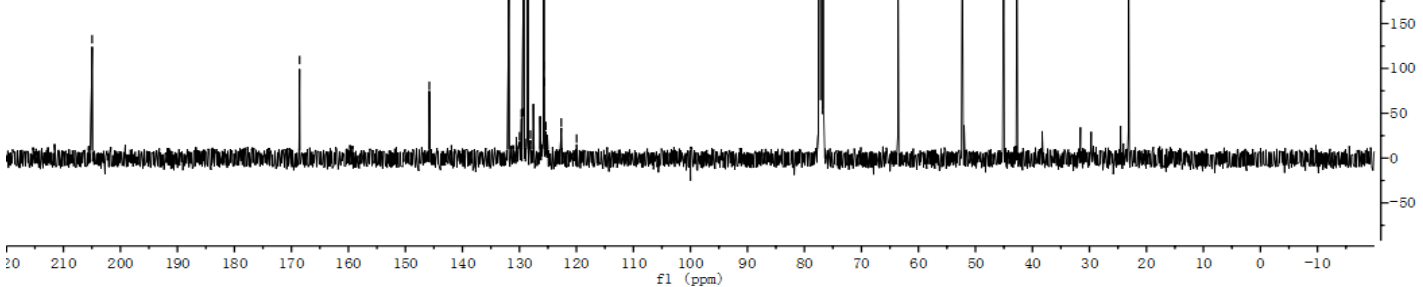


${ }^{19}$ F NMR (376 MHz, $\left.\mathrm{CDCl}_{3}\right)$

cmu6-193-2-F

i̊

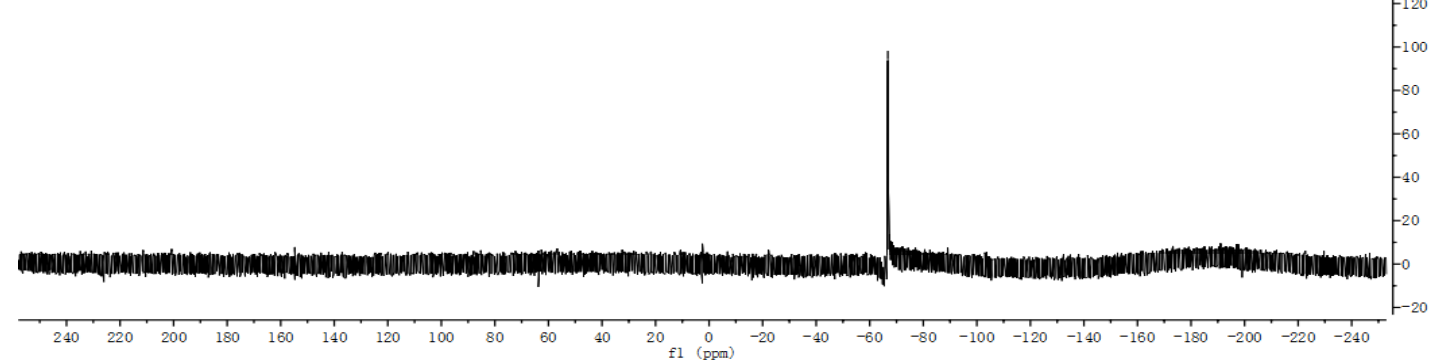




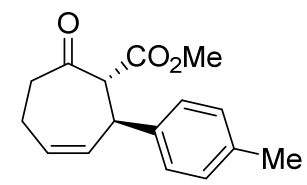

$4 e$

${ }^{1} \mathbf{H}$ NMR (400 MHz, $\mathrm{CDCl}_{3}$ )

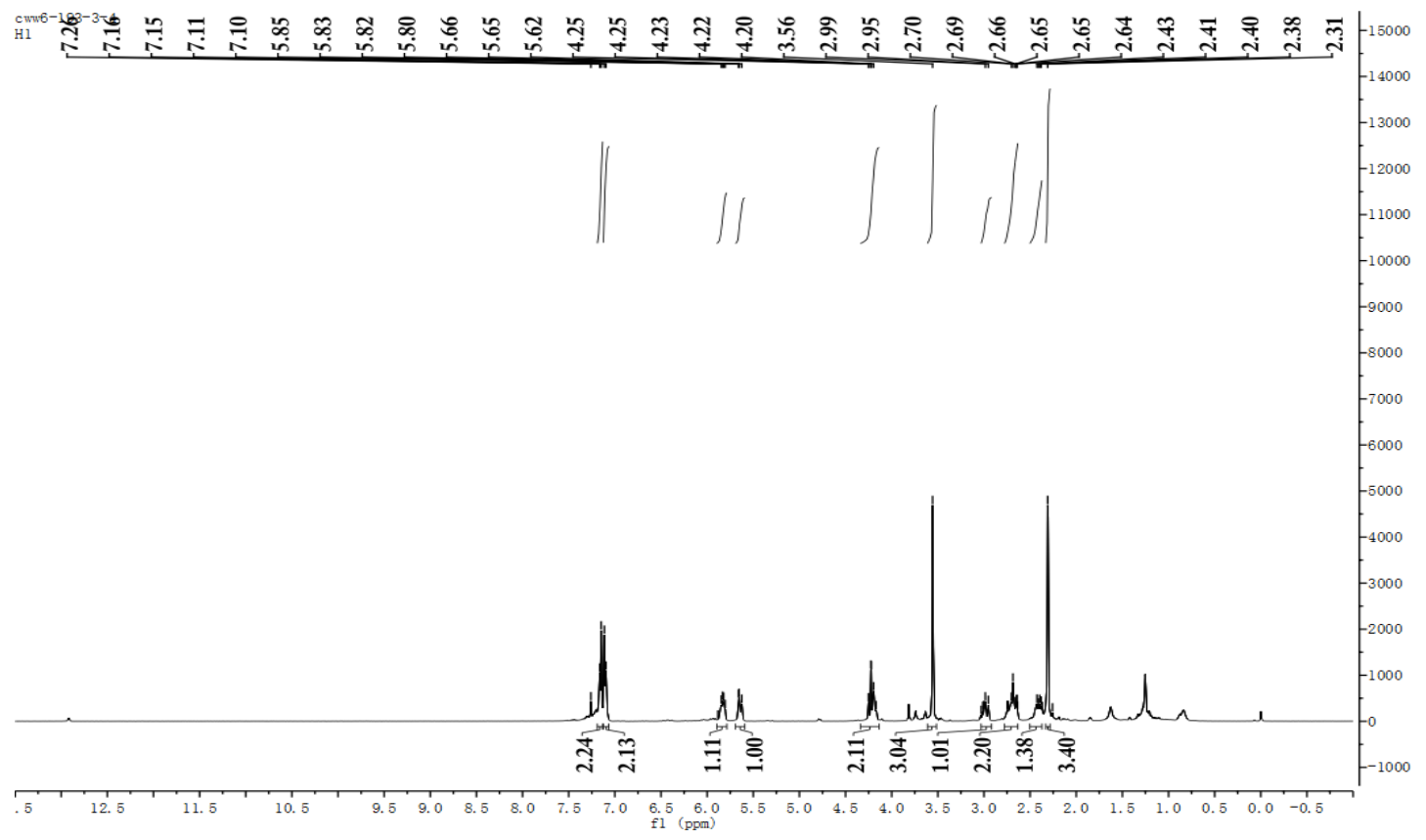

${ }^{13}$ C NMR (100 MHz, $\left.\mathrm{CDCl}_{3}\right)$

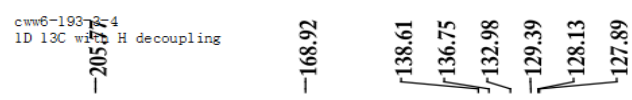

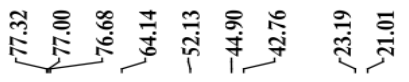

-1000
-1400
-1300
-1200
-1100
-1000
-900
-800
-700
-600
-400
-300
-200
-100
-100 

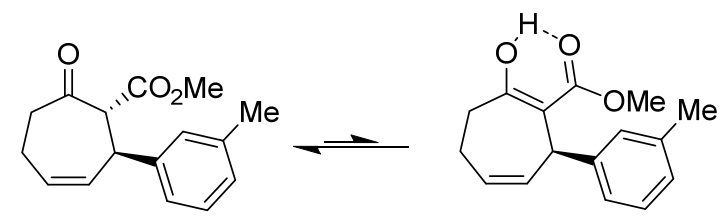

$4 f$

enol form

keto:enol $=14 \cdot 3: 1$

${ }^{1} \mathbf{H}$ NMR (400 MHz, $\left.\mathrm{CDCl}_{3}\right)$

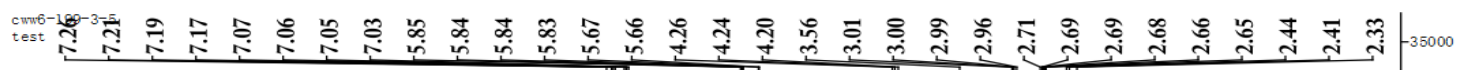
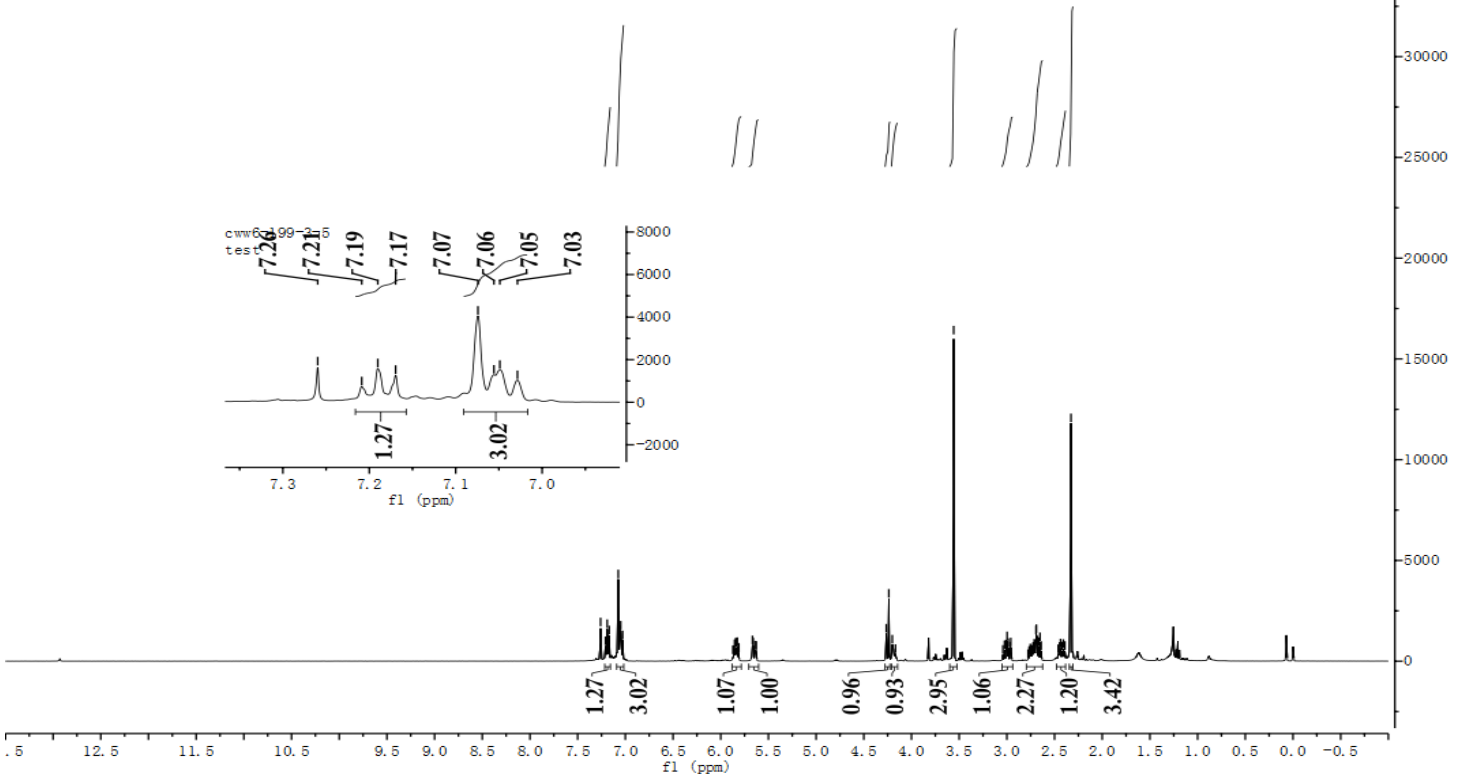

${ }^{13} \mathbf{C}$ NMR $\left(100 \mathrm{MHz}, \mathrm{CDCl}_{3}\right)$

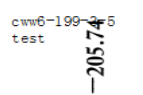

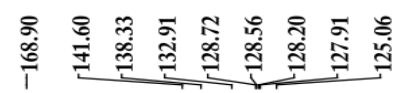

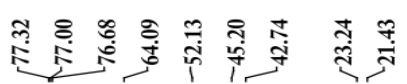

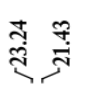

\begin{tabular}{l}
-700 \\
-700 \\
-650 \\
-600 \\
-550 \\
-500 \\
-450 \\
-300 \\
-300 \\
-250 \\
-200 \\
-150 \\
-100 \\
-50 \\
-50 \\
-50 \\
\hline-50 \\
\hline
\end{tabular}

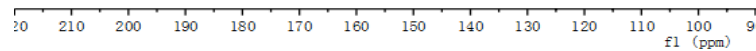




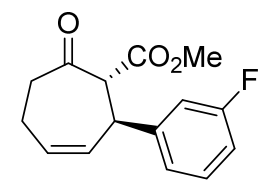

$4 \mathrm{~g}$

${ }^{1} \mathbf{H}$ NMR $\left(400 \mathrm{MHz}, \mathrm{CDCl}_{3}\right)$

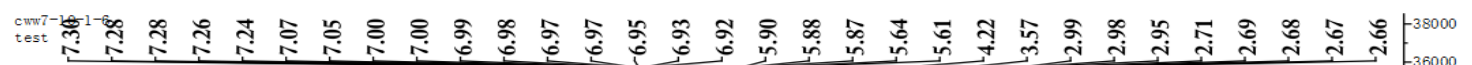

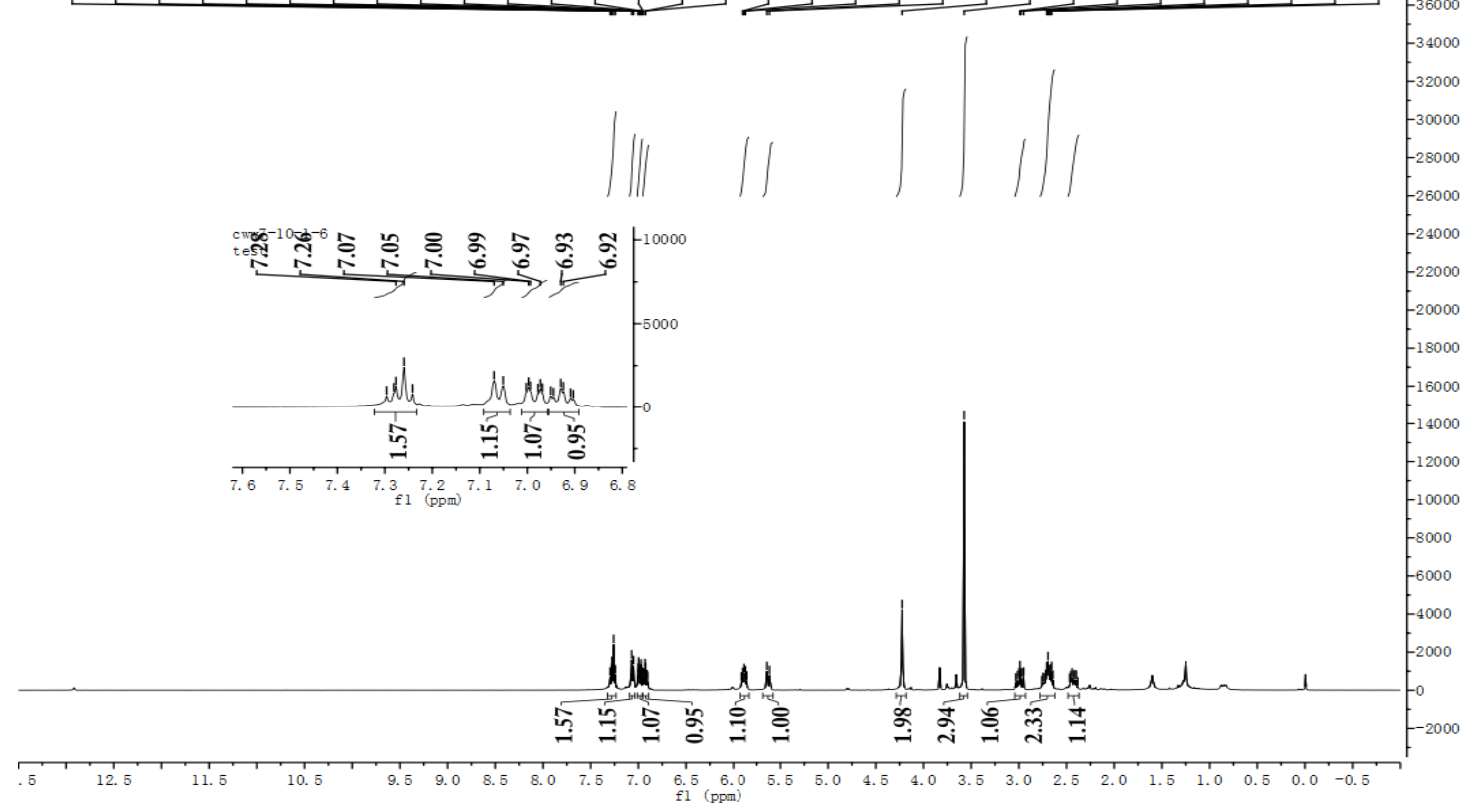

${ }^{13} \mathbf{C}$ NMR $\left(100 \mathrm{MHz}, \mathrm{CDCl}_{3}\right)$

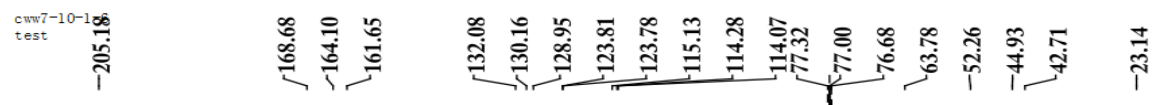

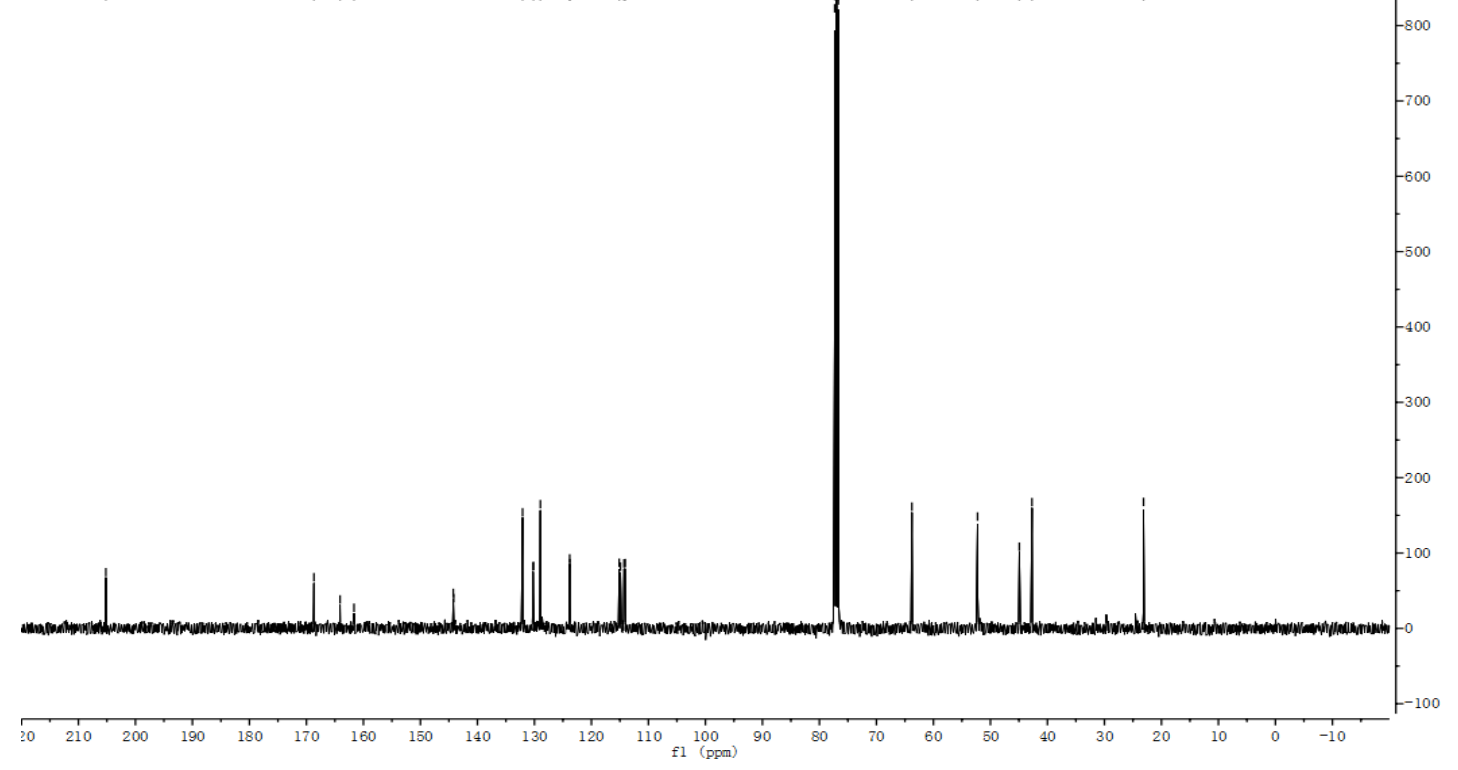


${ }^{19}$ F NMR $\left(376 \mathrm{MHz}, \mathrm{CDCl}_{3}\right)$

cmur-7-10-1-

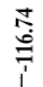

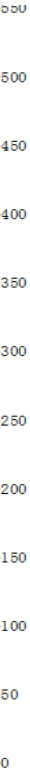

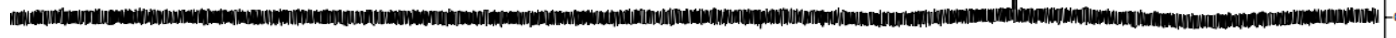

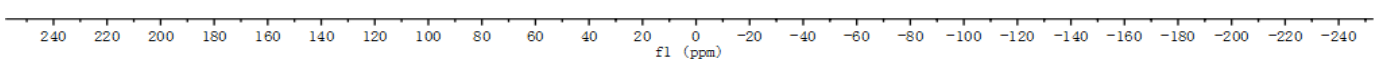


<smiles>CC(=O)[C@H]1C(=O)CCC=C[C@H]1c1ccccc1F</smiles>

${ }^{1} \mathbf{H}$ NMR $\left(400 \mathrm{MHz}, \mathrm{CDCl}_{3}\right)$

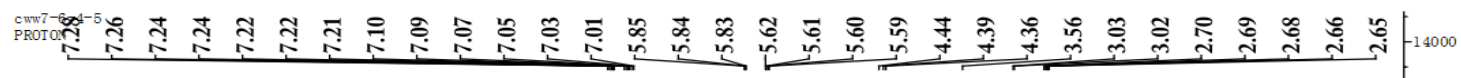
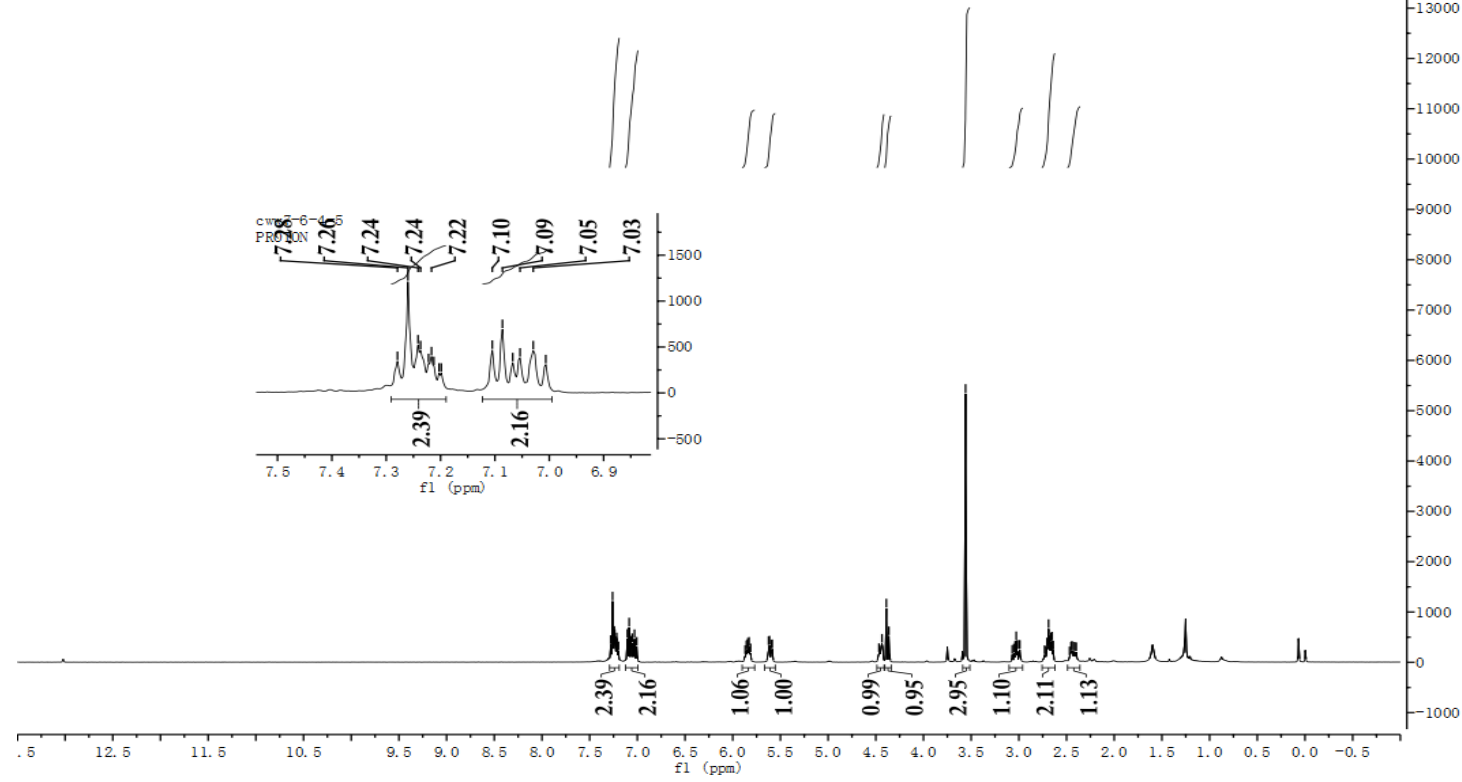

${ }^{13}$ C NMR $\left(100 \mathrm{MHz}, \mathrm{CDCl}_{3}\right)$

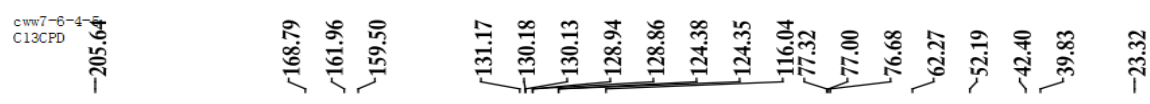

\section{13000
12000
-11000
-10000}


${ }^{19}$ F NMR (376 MHz, $\left.\mathrm{CDCl}_{3}\right)$

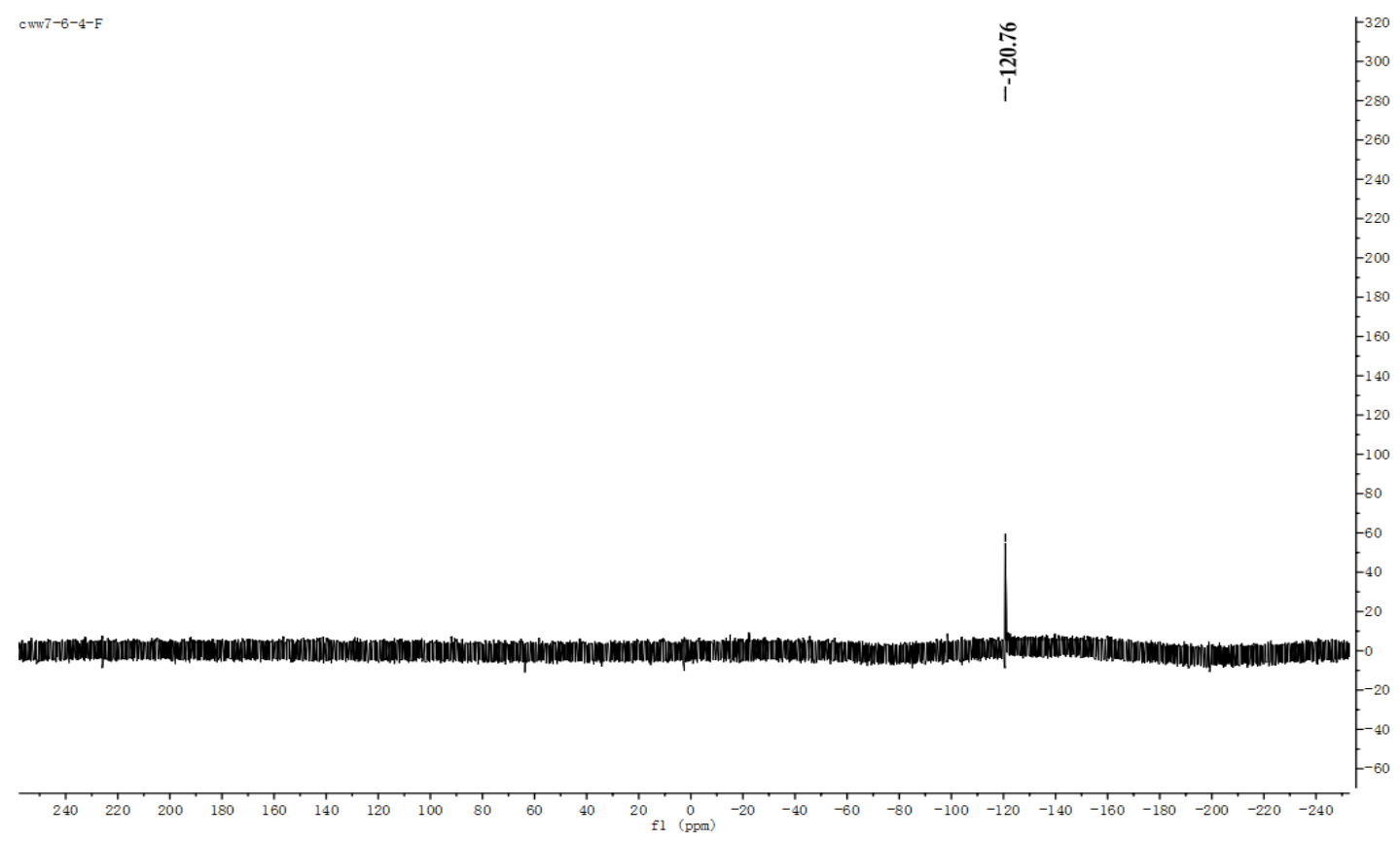


<smiles>CC(=O)OC1C(=O)CCC=CC1c1ccccc1C</smiles>

${ }^{1} \mathbf{H}$ NMR $\left(400 \mathrm{MHz}, \mathrm{CDCl}_{3}\right)$

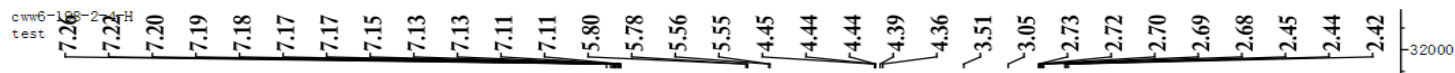

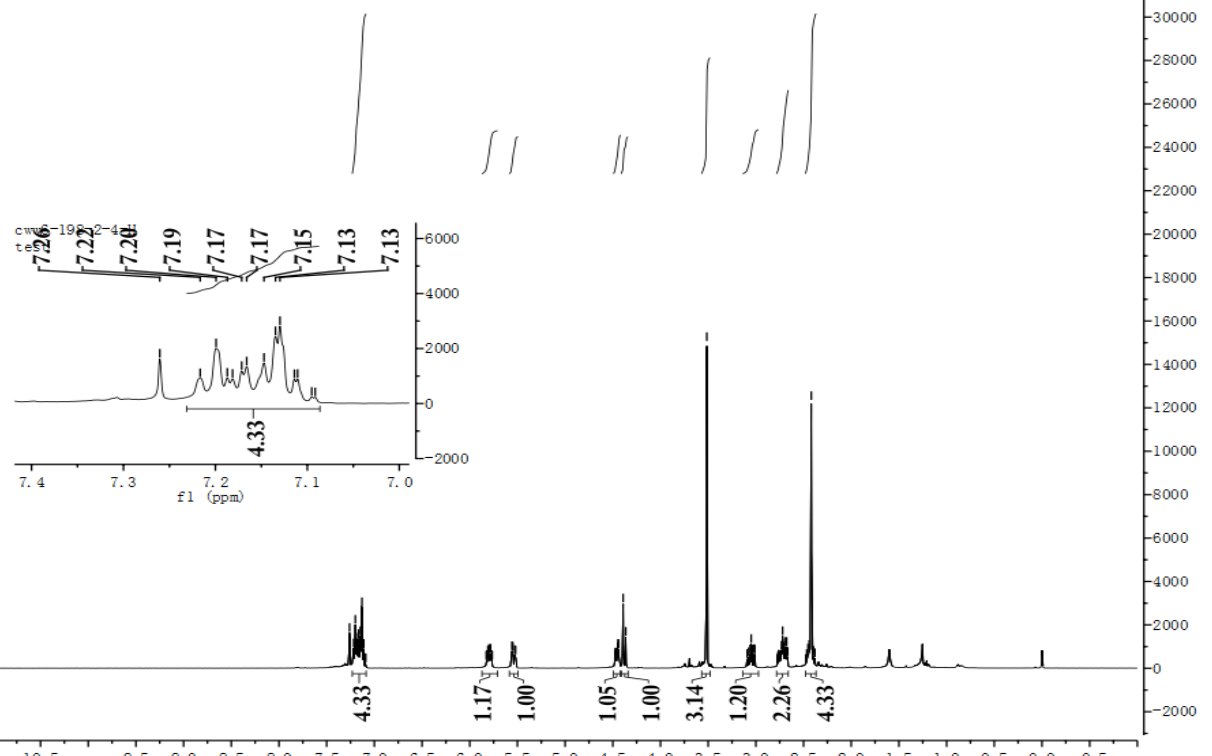

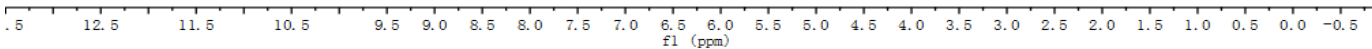

${ }^{13} \mathbf{C}$ NMR $\left(100 \mathrm{MHz}, \mathrm{CDCl}_{3}\right)$

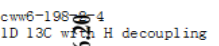

市

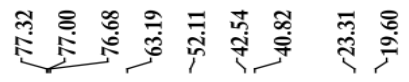

$-1900$ 


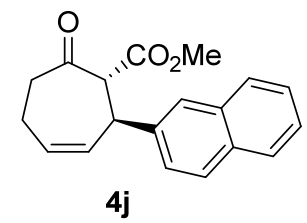

${ }^{1} \mathbf{H}$ NMR (400 MHz, $\left.\mathrm{CDCl}_{3}\right)$

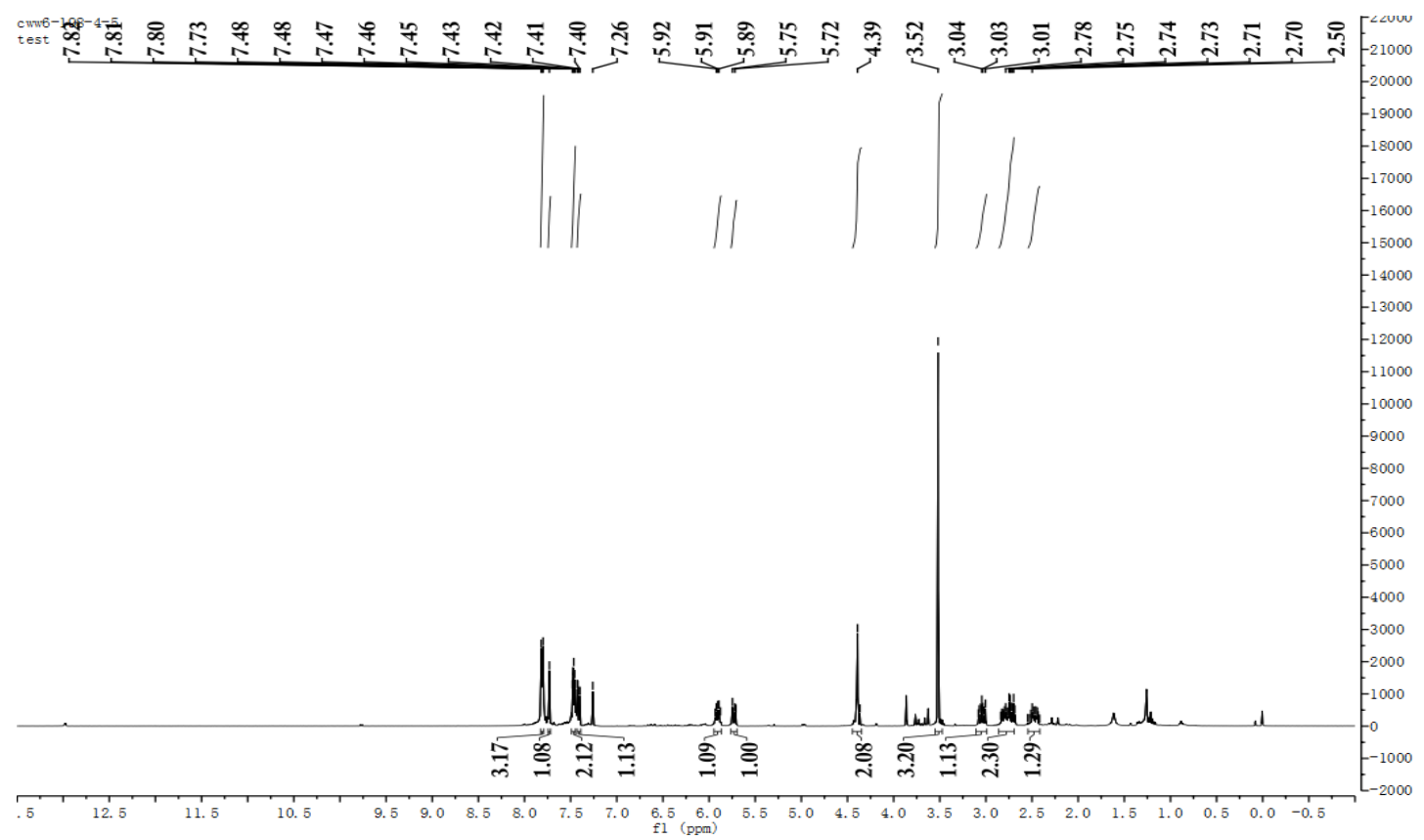

${ }^{13}$ C NMR (100 MHz, $\left.\mathrm{CDCl}_{3}\right)$

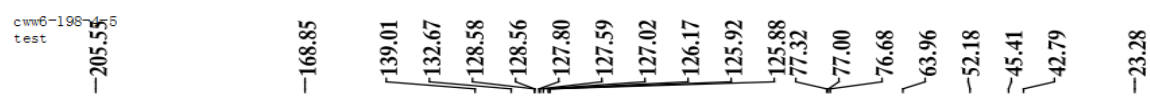

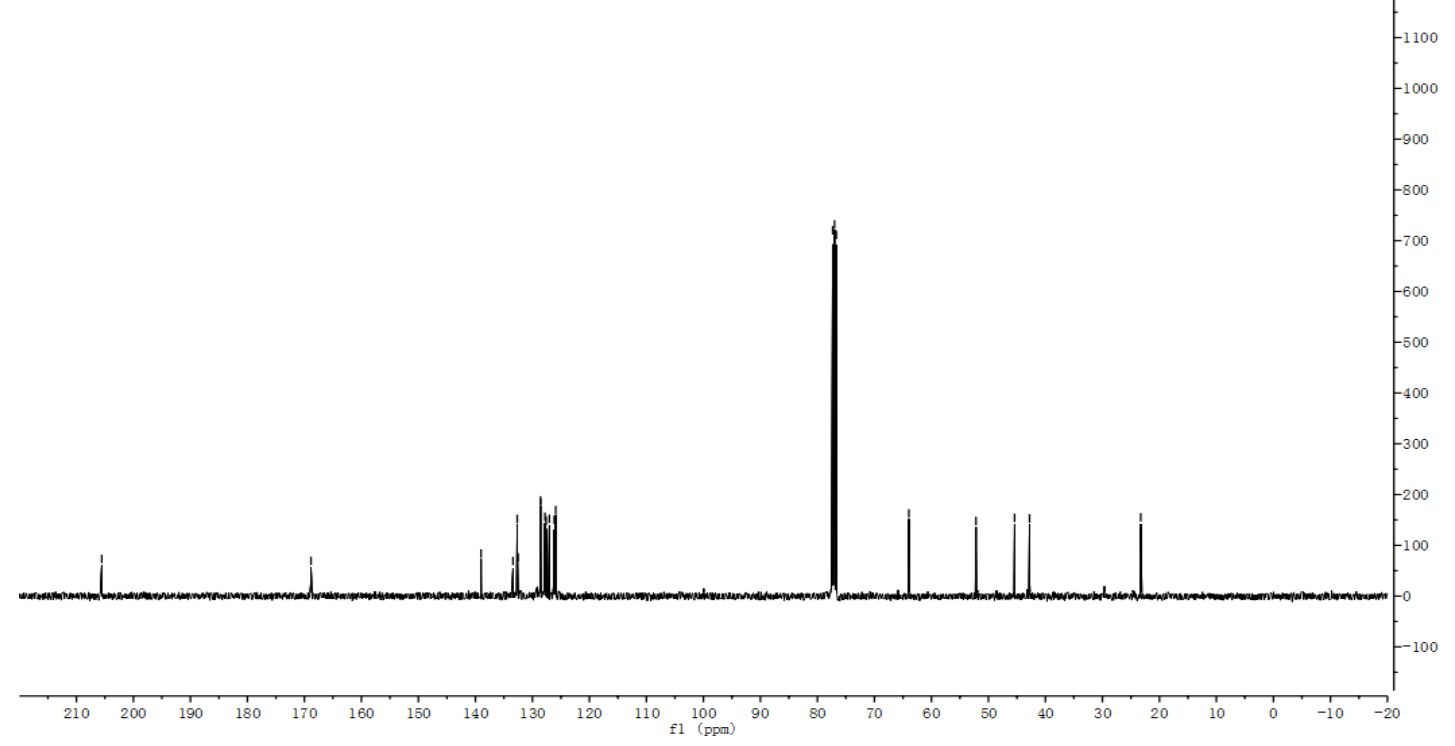


<smiles>CC(=O)C1C(=O)CCC=CC1c1cccc2ccccc12</smiles>

${ }^{1} \mathbf{H}$ NMR (400 MHz, $\left.\mathrm{CDCl}_{3}\right)$

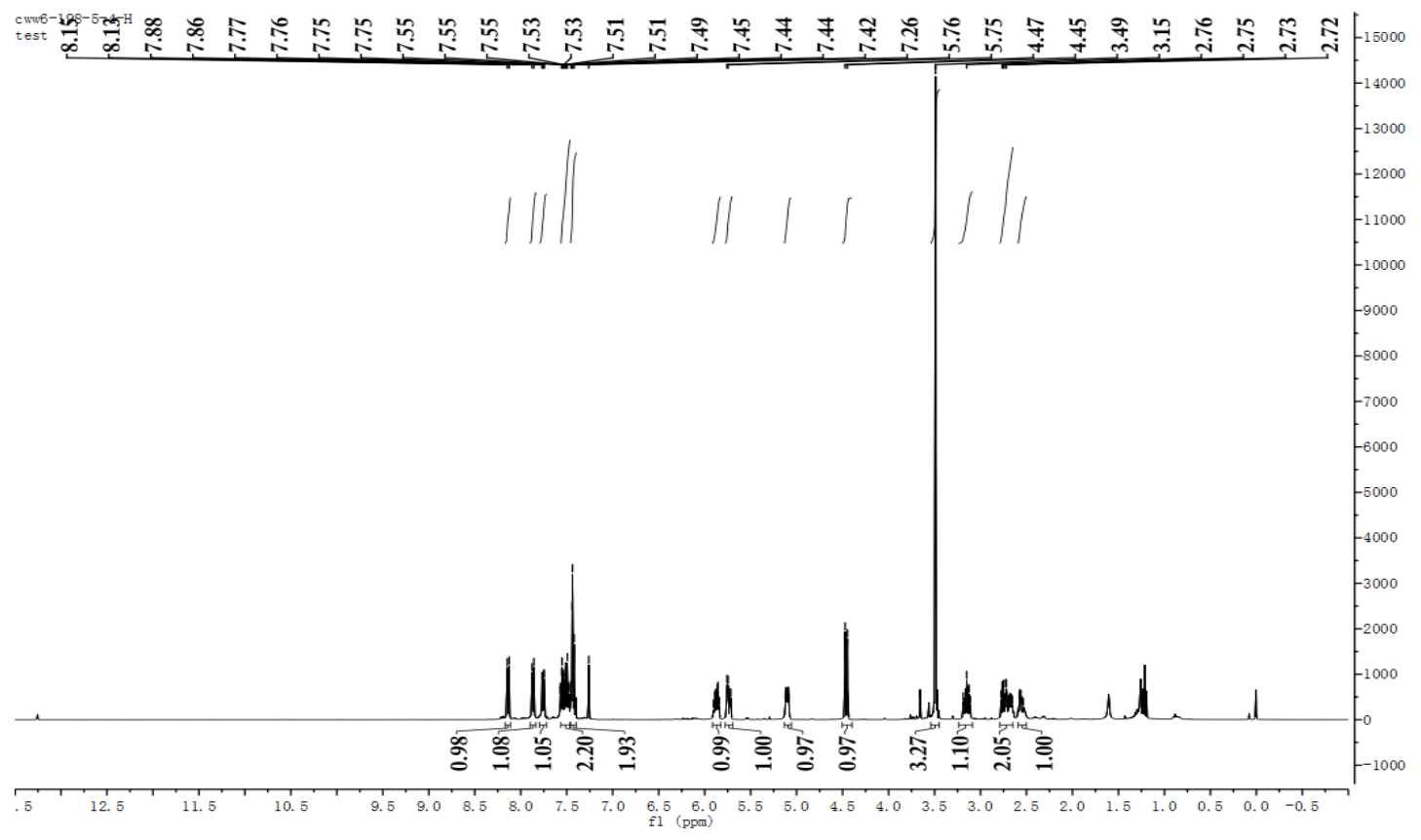

${ }^{13} \mathbf{C}$ NMR $\left(100 \mathrm{MHz}, \mathrm{CDCl}_{3}\right)$

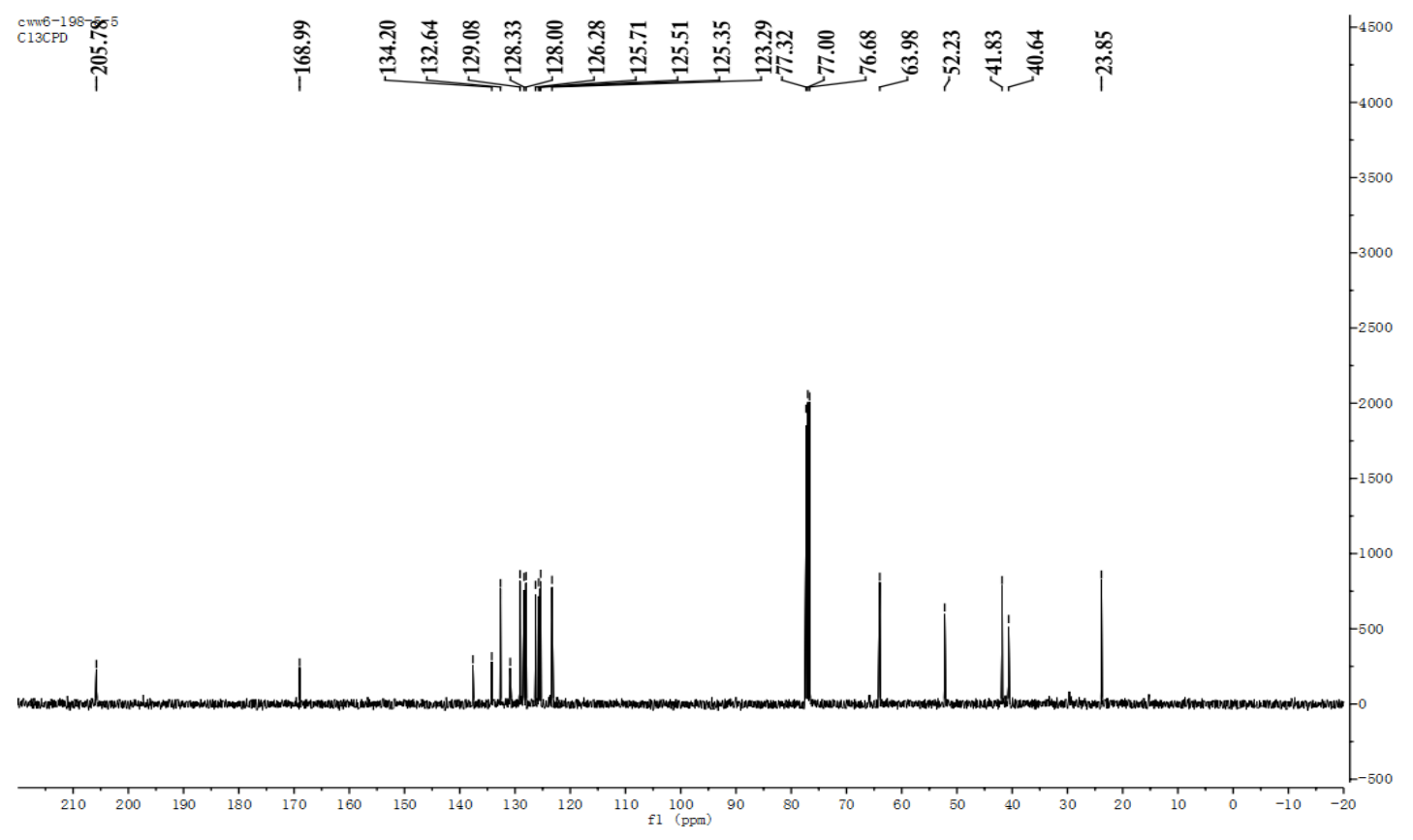




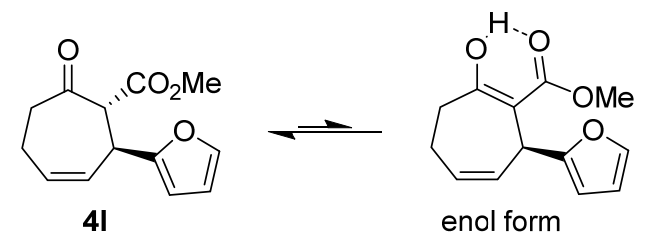

keto:enol $=7.7: 1$

${ }^{1} \mathbf{H}$ NMR (400 MHz, $\left.\mathrm{CDCl}_{3}\right)$

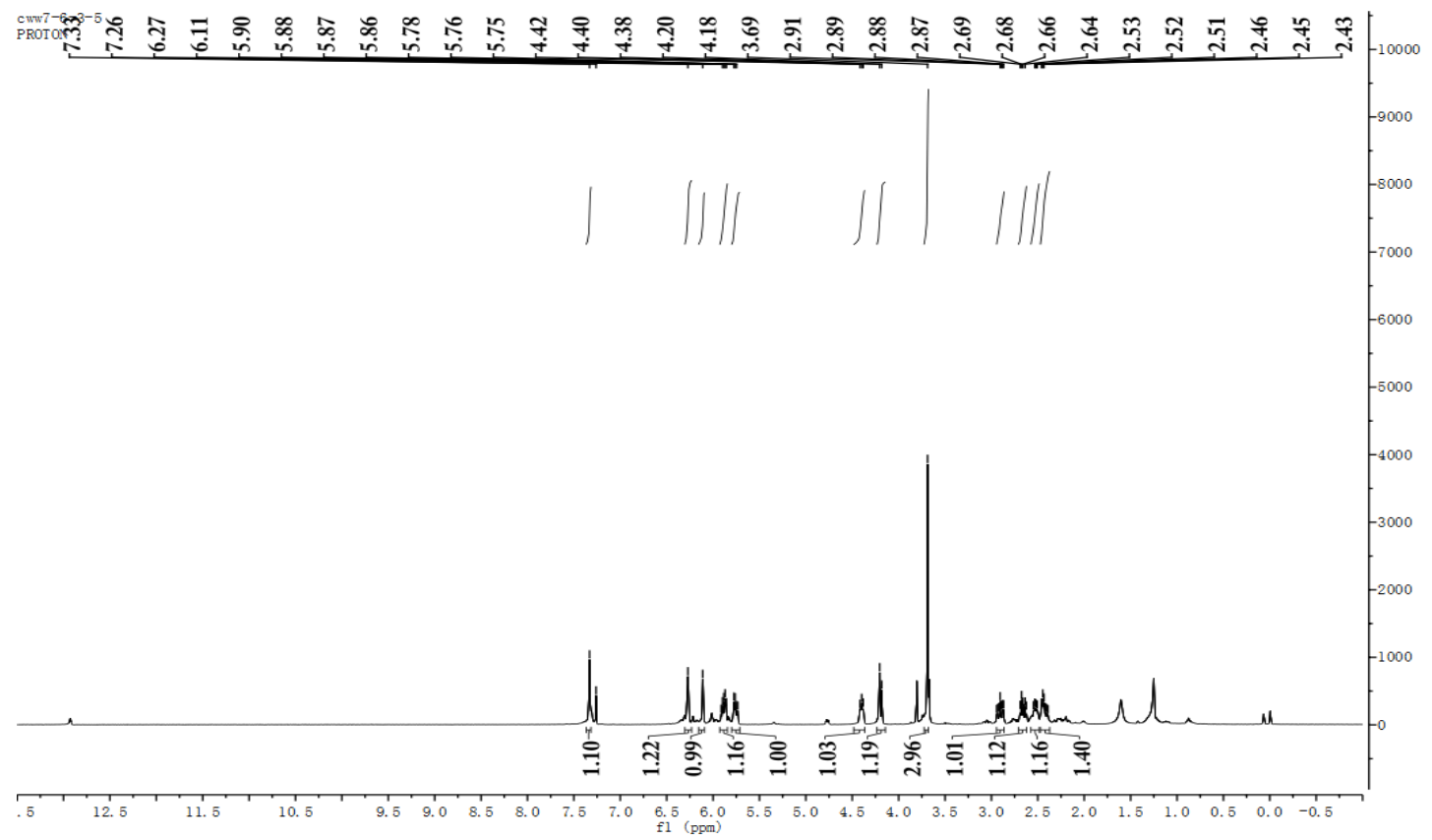

${ }^{13} \mathbf{C ~ N M R}\left(100 \mathrm{MHz}, \mathrm{CDCl}_{3}\right)$

C13CPD

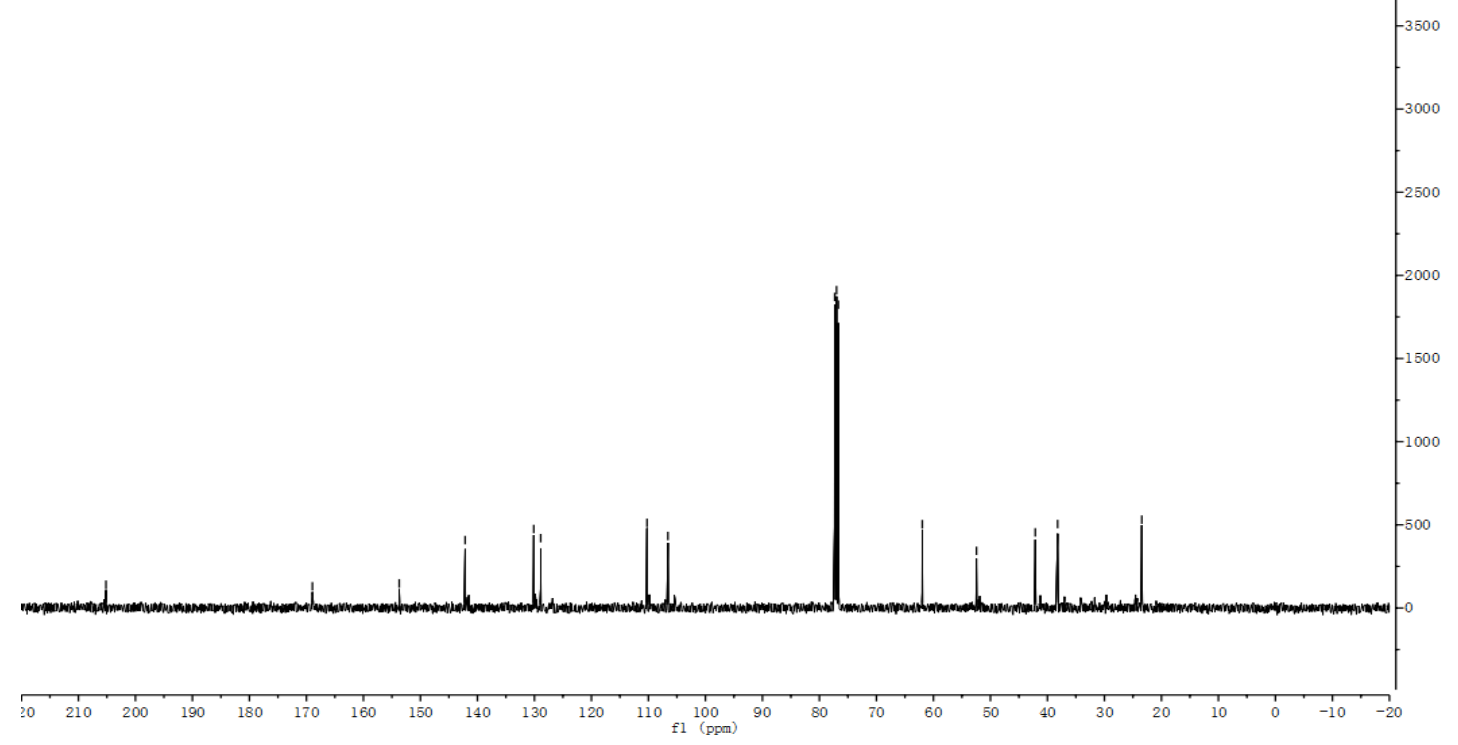




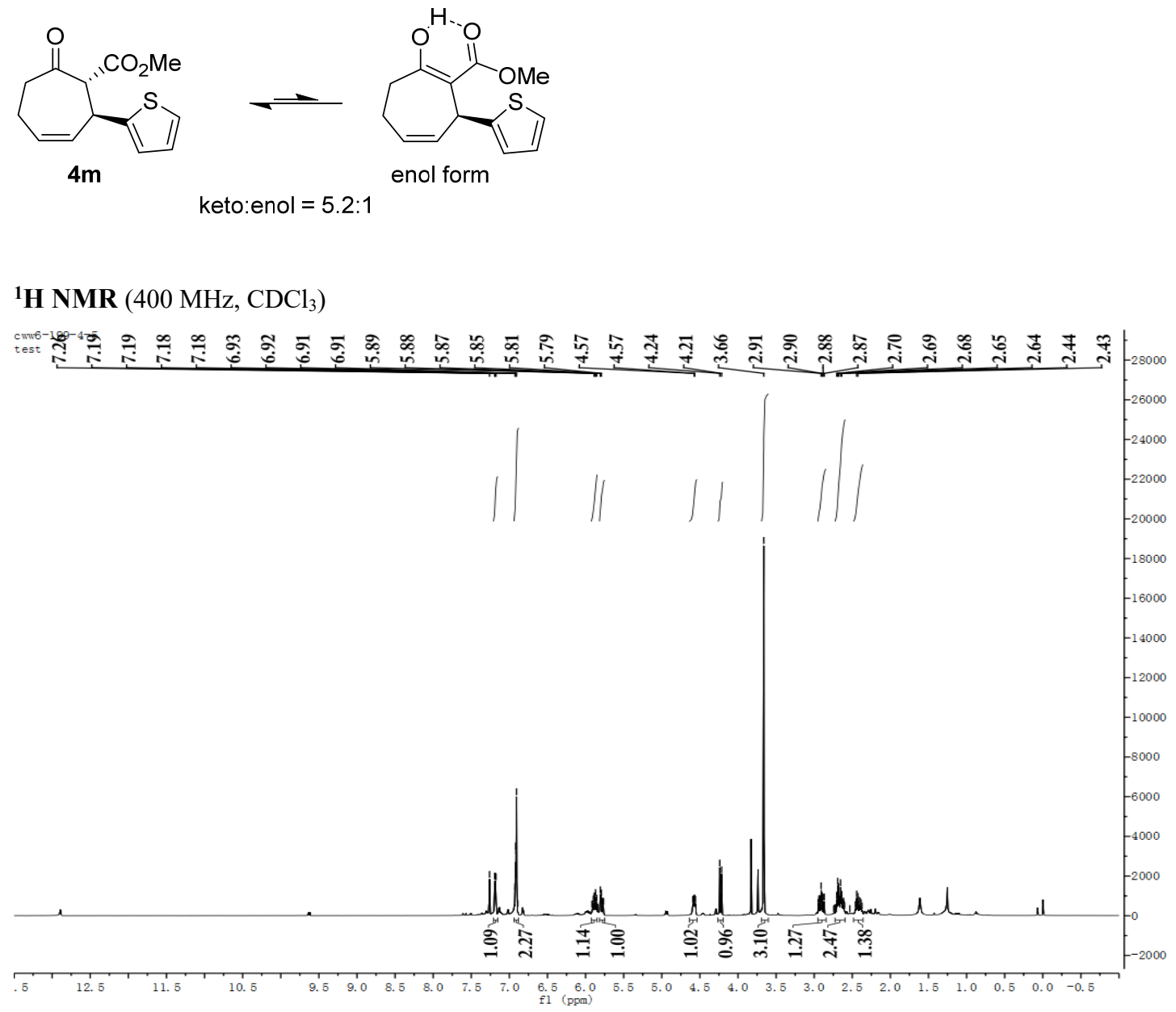

${ }^{13}$ C NMR (100 MHz, $\left.\mathrm{CDCl}_{3}\right)$

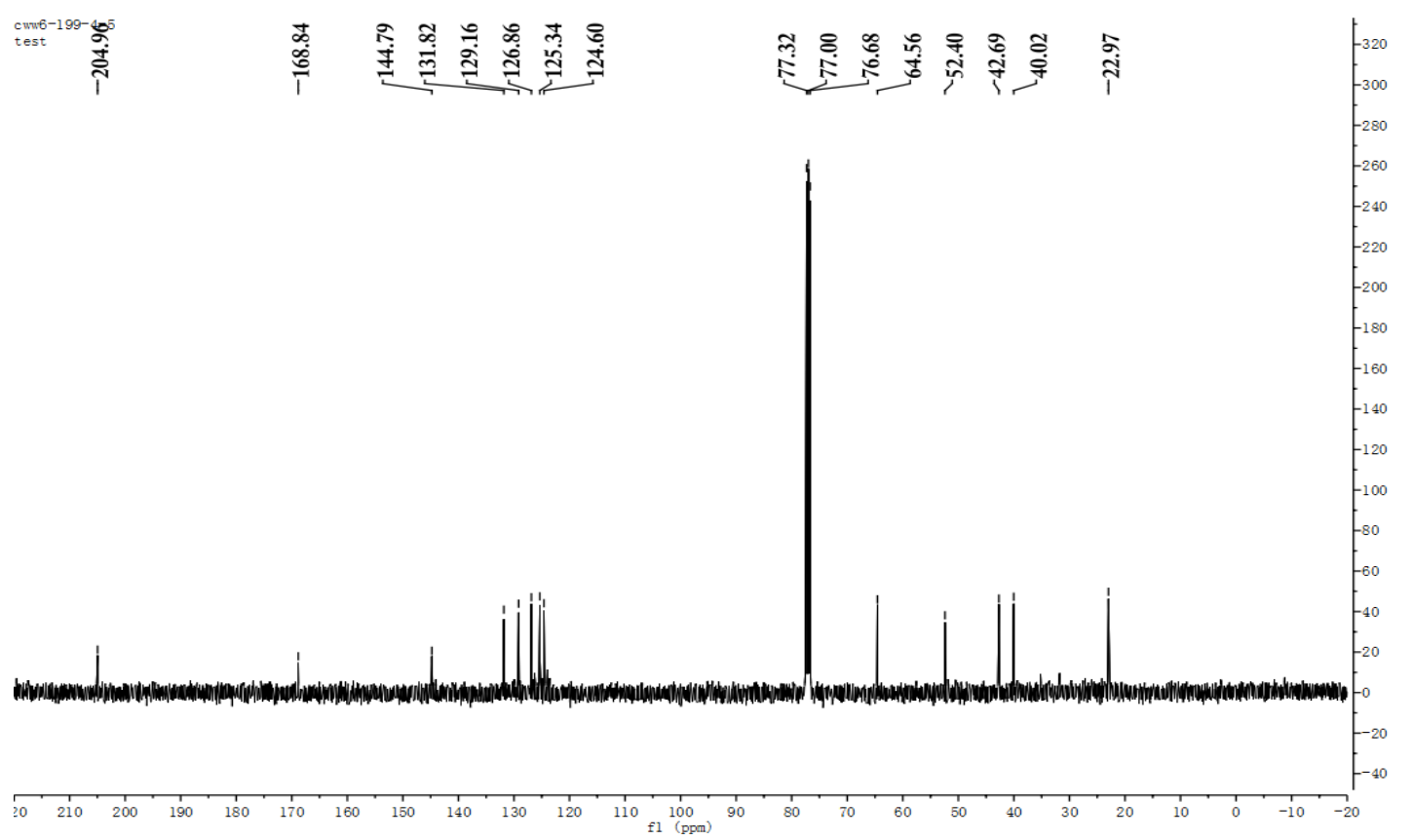




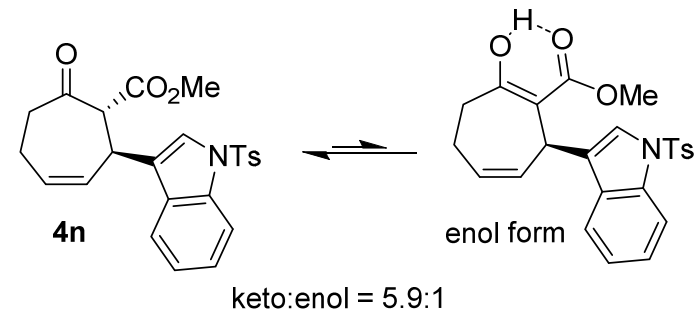

${ }^{1} \mathbf{H}$ NMR $\left(400 \mathrm{MHz}, \mathrm{CDCl}_{3}\right)$

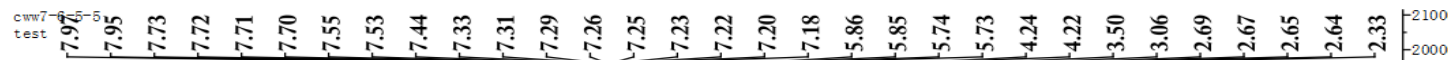
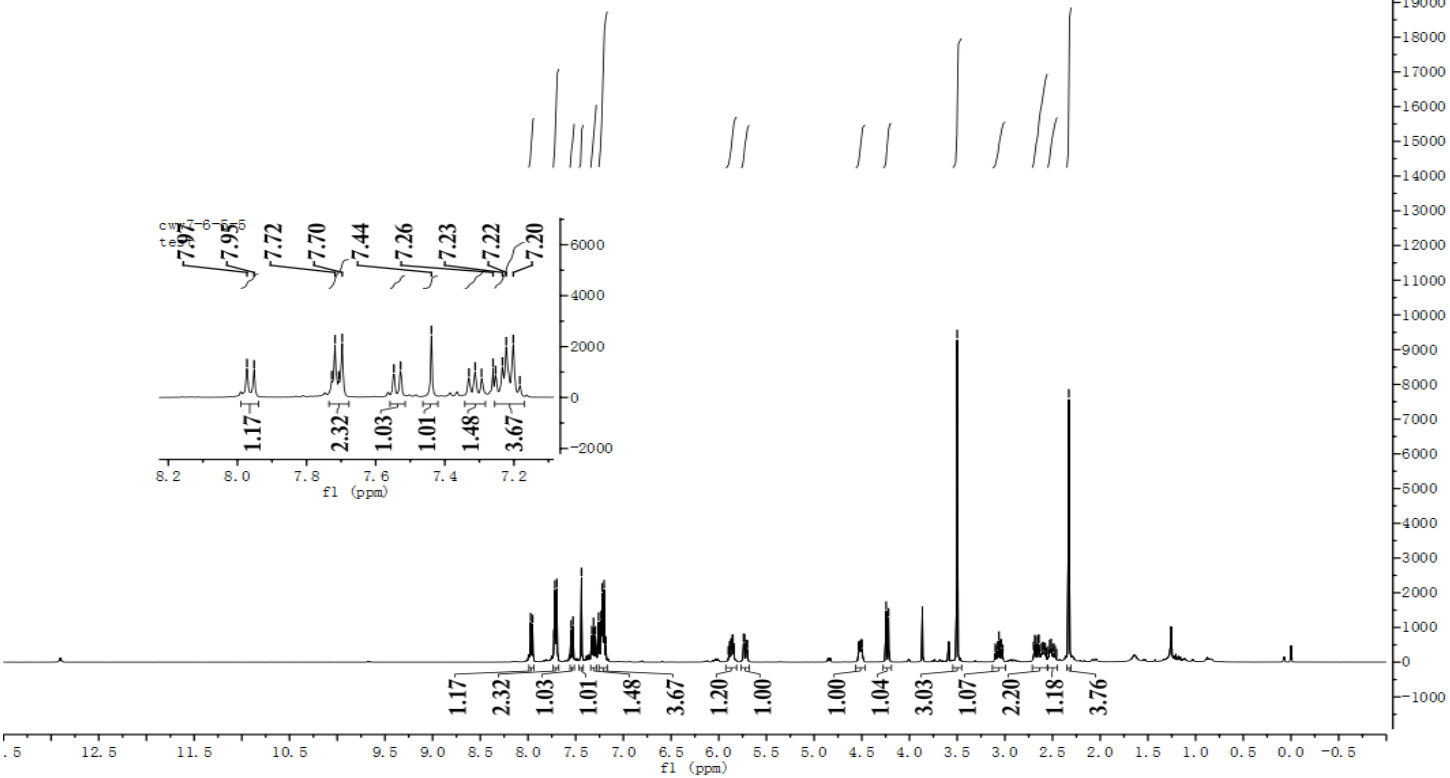

${ }^{13} \mathbf{C}$ NMR $\left(100 \mathrm{MHz}, \mathrm{CDCl}_{3}\right)$

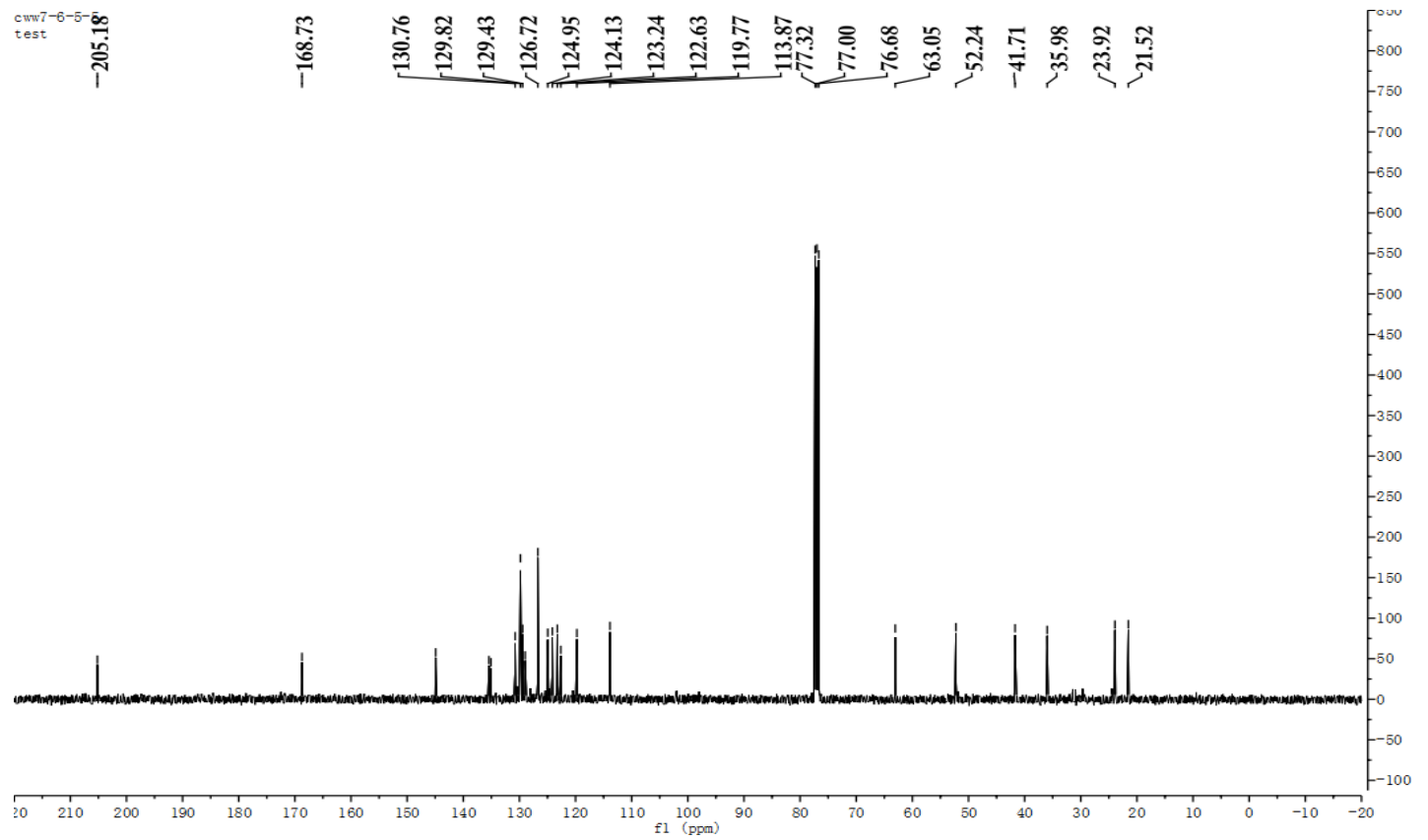



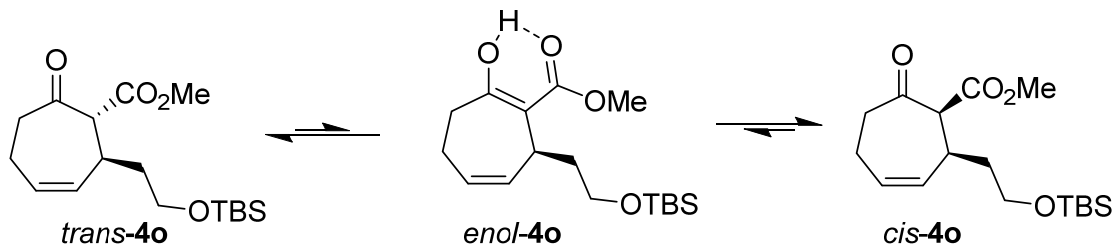

keto:enol $=20: 1$

${ }^{1} \mathbf{H}$ NMR (400 MHz, $\left.\mathrm{CDCl}_{3}\right)$

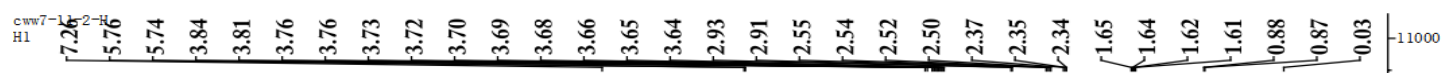

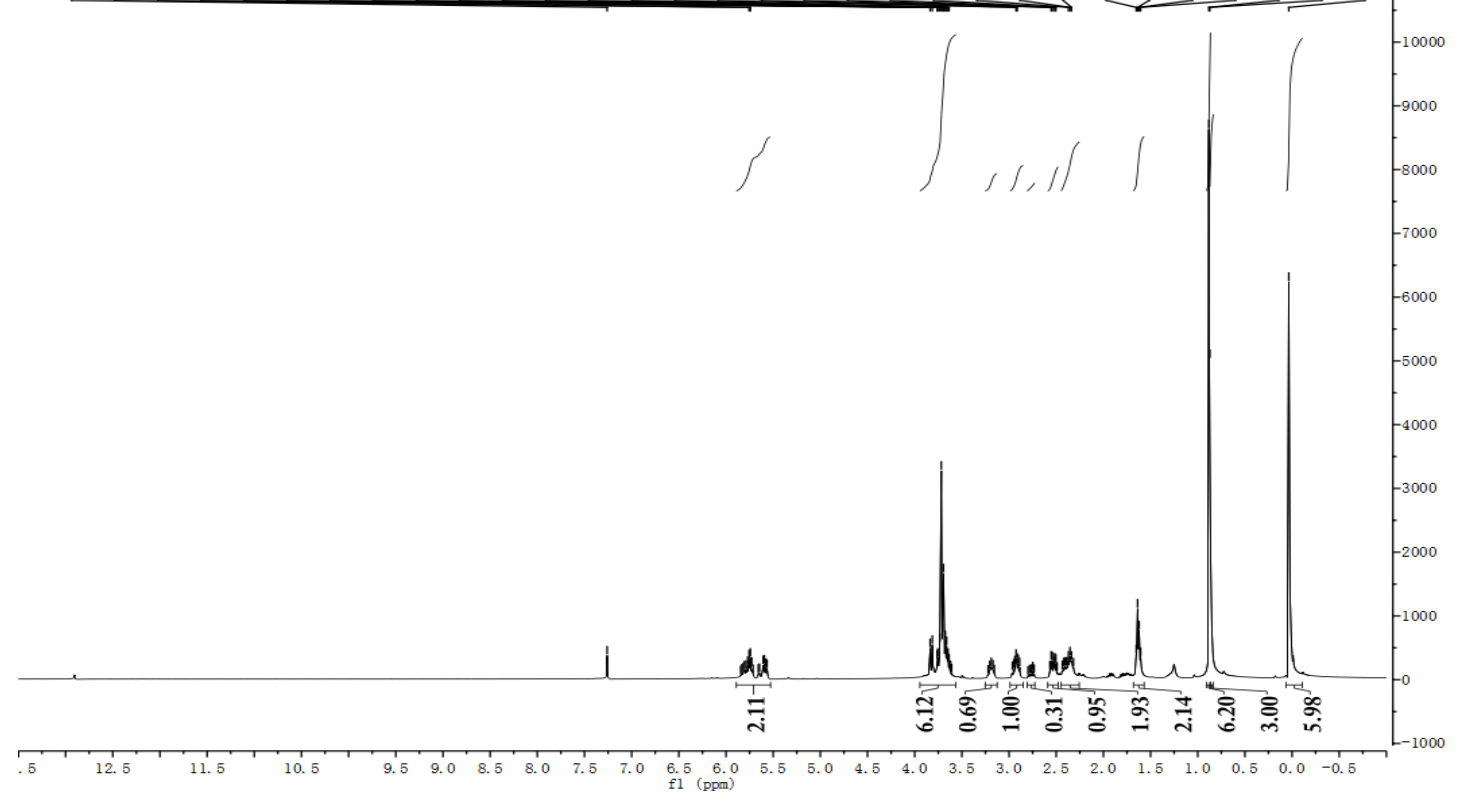

${ }^{13}$ C NMR $\left(100 \mathrm{MHz}, \mathrm{CDCl}_{3}\right)$

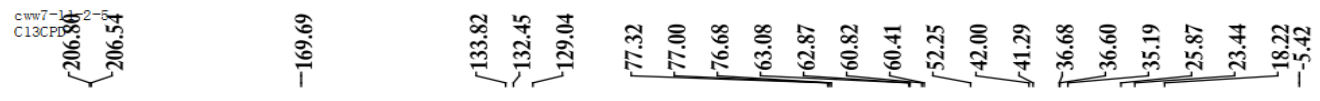

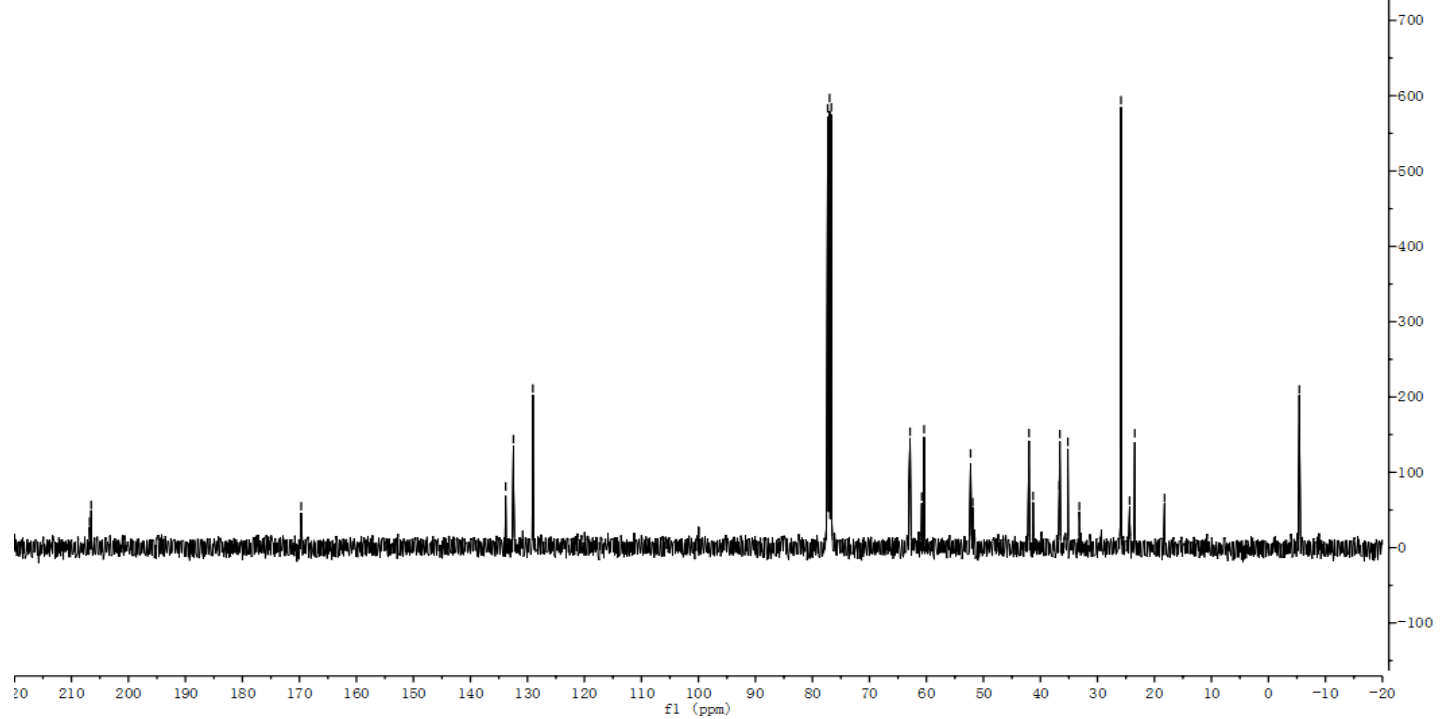


<smiles>COC(=O)[C@H]1[C@@H](O)CCC=C[C@H]1c1ccccc1</smiles>

$5 a$

${ }^{1} \mathbf{H}$ NMR $\left(400 \mathrm{MHz}, \mathrm{CDCl}_{3}\right)$

test
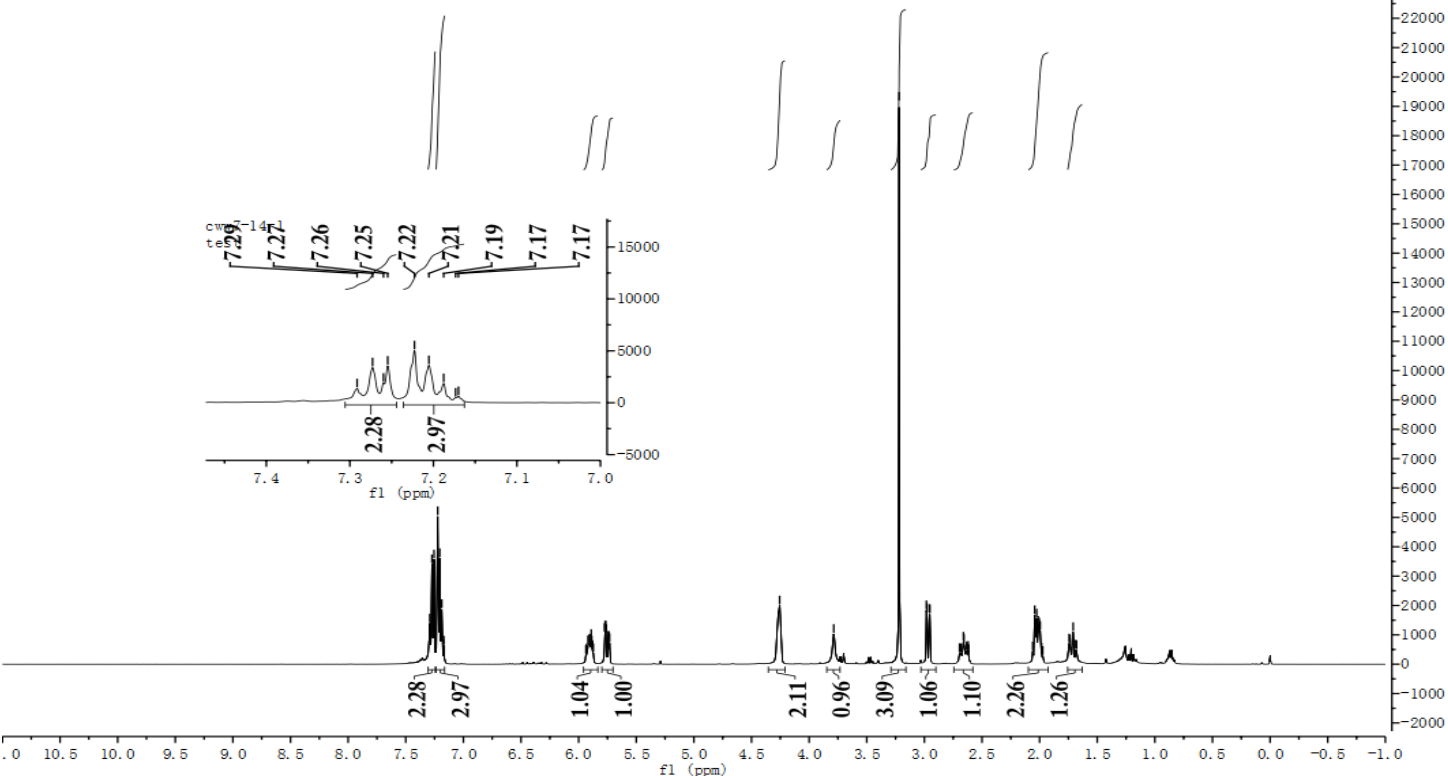

${ }^{13}$ C NMR $\left(100 \mathrm{MHz}, \mathrm{CDCl}_{3}\right)$

$\underset{t=5 t}{\operatorname{cow} 7-14-1}$

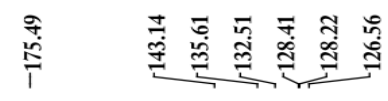

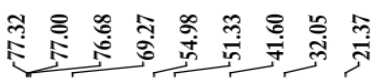

-900
-850
-800
-750
-700
-650
-600
-550
-500
-450
-400
-350
-300
-250
-200
-150
-100
50
-0
-50
-100

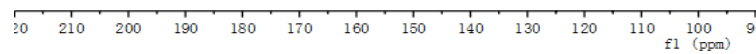




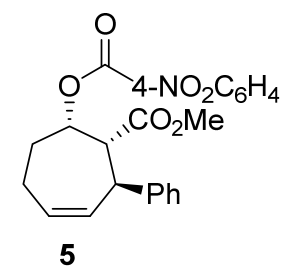

${ }^{1} \mathbf{H}$ NMR (400 MHz, $\left.\mathrm{CDCl}_{3}\right)$

PROT0m

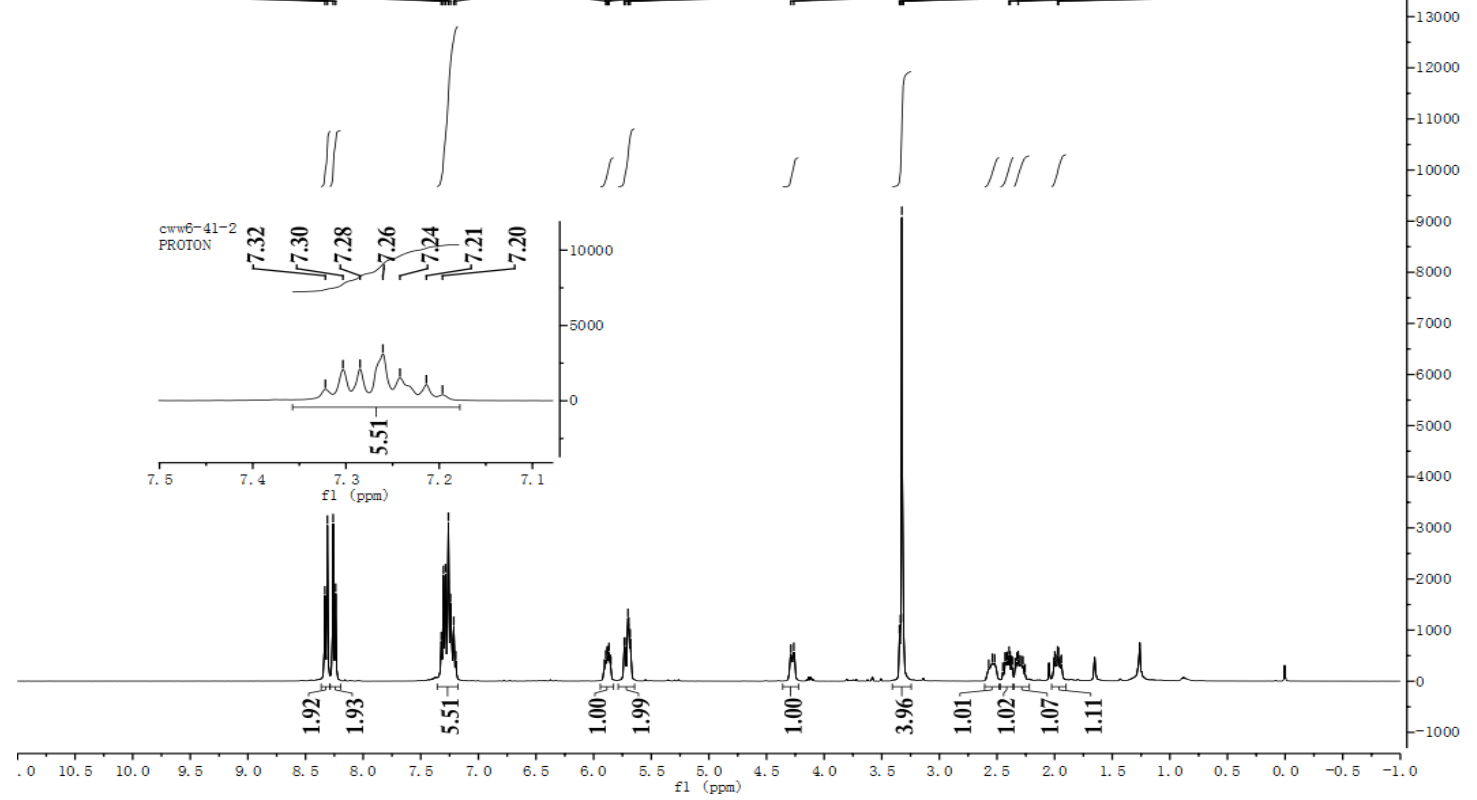

${ }^{13}$ C NMR $\left(100 \mathrm{MHz}, \mathrm{CDCl}_{3}\right)$

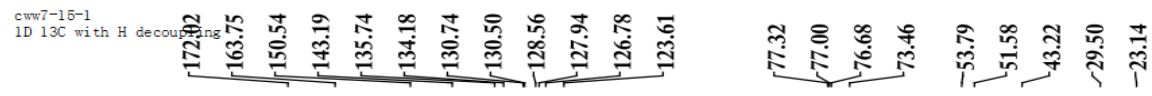

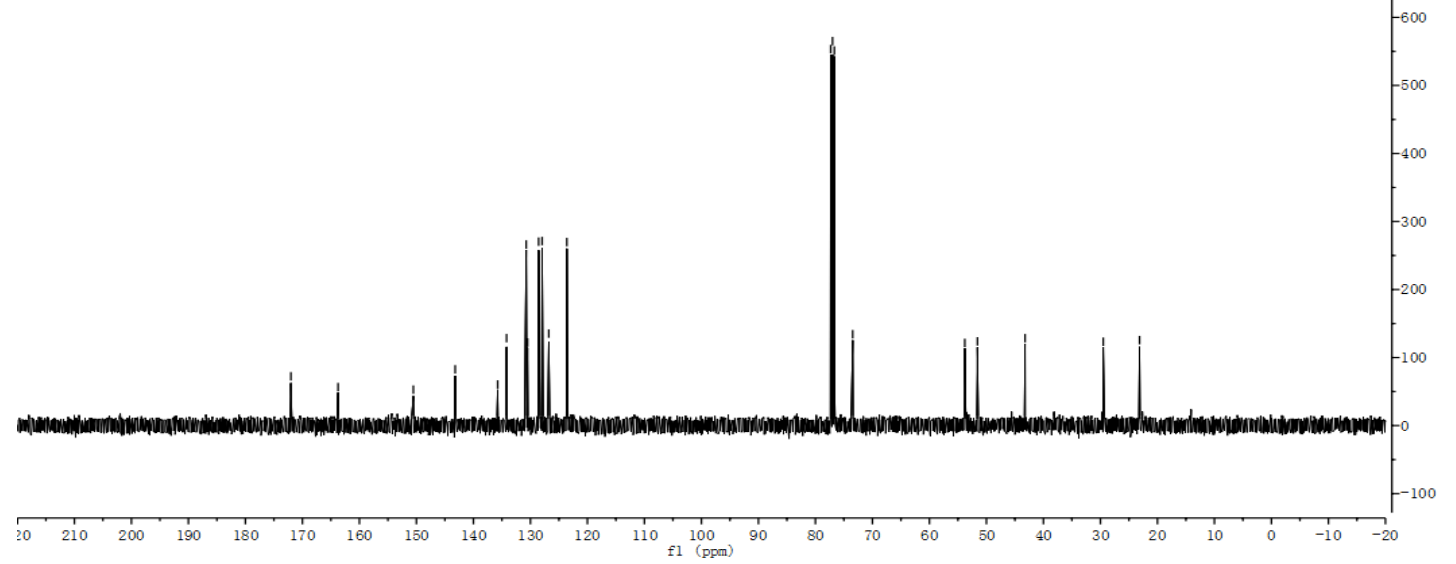

